Cochrane Database of Systematic Reviews

\title{
Print-based self-help interventions for smoking cessation (Review)
}

Livingstone-Banks J, Ordóñez-Mena JM, Hartmann-Boyce J

Livingstone-Banks J, Ordóñez-Mena JM, Hartmann-Boyce J.

Print-based self-help interventions for smoking cessation.

Cochrane Database of Systematic Reviews 2019, Issue 1. Art. No.: CD001118.

DOI: 10.1002/14651858.CD001118.pub4.

www.cochranelibrary.com 
TABLE OF CONTENTS

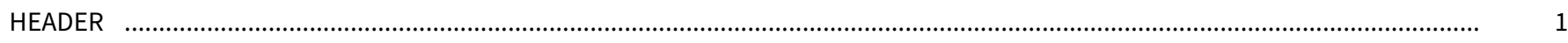

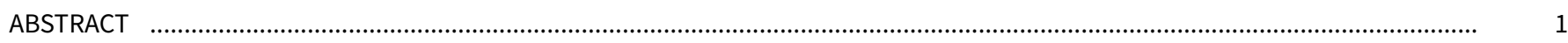

PLAIN LANGUAGE SUMMARY

SUMMARY OF FINDINGS

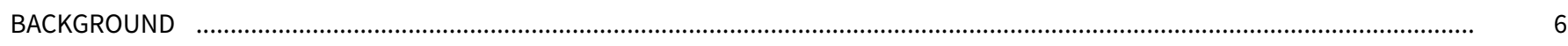

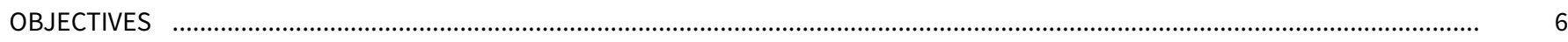

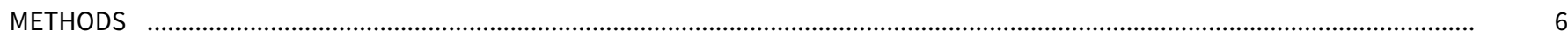

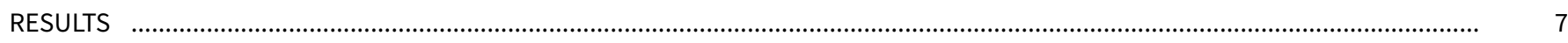

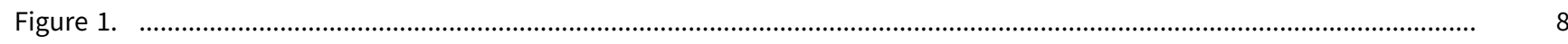

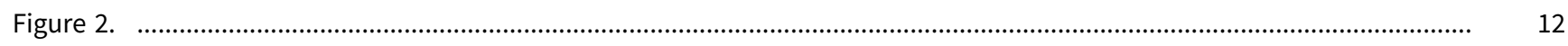

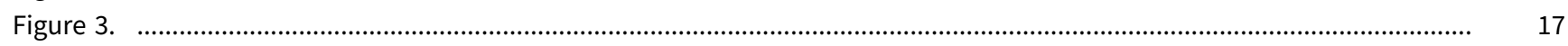

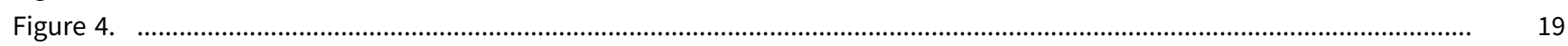

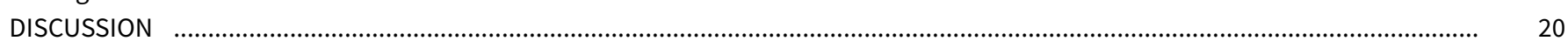

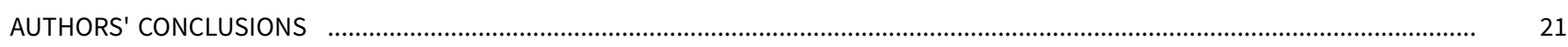

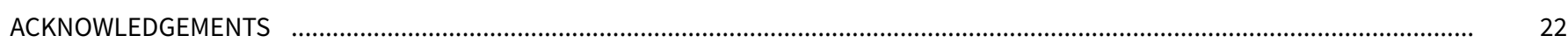

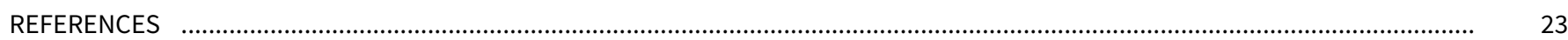

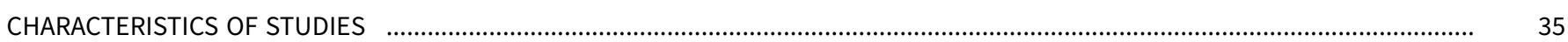

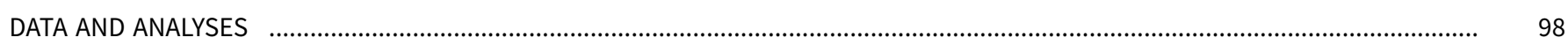

Analysis 1.1. Comparison 1 Non-tailored self-help vs no self-help, pooled by amount of contact, Outcome 1 Neither group had 99 face-to-face contact (long-term abstinence).

Analysis 1.2. Comparison 1 Non-tailored self-help vs no self-help, pooled by amount of contact, Outcome 2 Neither group had 100 face-to-face contact (Becona studies only).

Analysis 1.3. Comparison 1 Non-tailored self-help vs no self-help, pooled by amount of contact, Outcome 3 Both groups had face-to-face contact (long-term abstinence).

Analysis 1.4. Comparison 1 Non-tailored self-help vs no self-help, pooled by amount of contact, Outcome 4 Both groups had face-to-face contact with advice (long-term abstinence).

Analysis 2.1. Comparison 2 Non-tailored self-help vs no self-help, pooling all studies, Outcome 1 Long-term abstinence. ....... 102

Analysis 3.1. Comparison 3 Tailored self-help vs no self-help, Outcome 1 Long-term abstinence. ................................................ 104

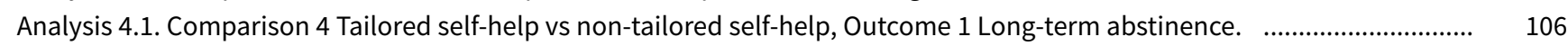

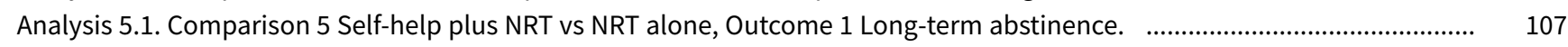

Analysis 6.1. Comparison 6 Other enhancements/adjuncts to self-help materials, Outcome 1 Long-term abstinence. .............. 107

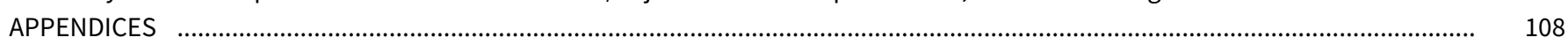

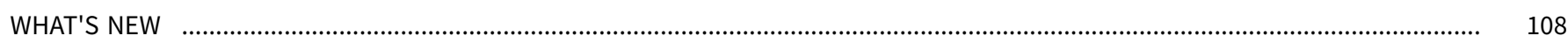

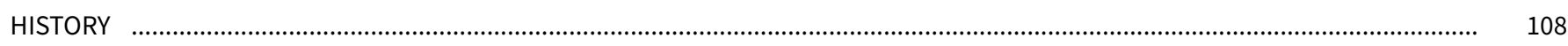

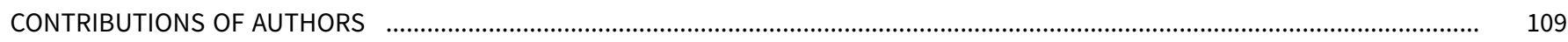

DECLARATIONS OF INTEREST

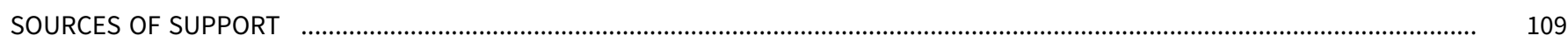

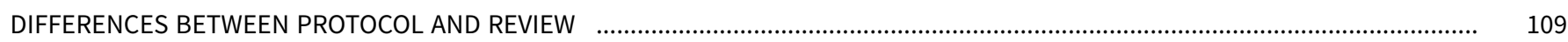

INDEX TERMS 
[Intervention Review]

\section{Print-based self-help interventions for smoking cessation}

Jonathan Livingstone-Banks ${ }^{1}$, José M. Ordóñez-Mena ${ }^{1}$, Jamie Hartmann-Boyce1

1Nuffield Department of Primary Care Health Sciences, University of Oxford, Oxford, UK

Contact address: Jamie Hartmann-Boyce, Nuffield Department of Primary Care Health Sciences, University of Oxford, Oxford, UK. jamie.hartmann-boyce@phc.ox.ac.uk.

Editorial group: Cochrane Tobacco Addiction Group.

Publication status and date: Edited (no change to conclusions), published in Issue 1, 2019.

Citation: Livingstone-Banks J, Ordóñez-Mena JM, Hartmann-Boyce J. Print-based self-help interventions for smoking cessation. Cochrane Database of Systematic Reviews 2019, Issue 1. Art. No.: CD001118. DOI: 10.1002/14651858.CD001118.pub4.

Copyright @ 2019 The Cochrane Collaboration. Published by John Wiley \& Sons, Ltd.

\section{A B S T R A C T}

\section{Background}

Many smokers give up smoking on their own, but materials that provide a structured programme for smokers to follow may increase the number who quit successfully.

\section{Objectives}

The aims of this review were to determine the effectiveness of different forms of print-based self-help materials that provide a structured programme for smokers to follow, compared with no treatment and with other minimal contact strategies, and to determine the comparative effectiveness of different components and characteristics of print-based self-help, such as computer-generated feedback, additional materials, tailoring of materials to individuals, and targeting of materials at specific groups.

\section{Search methods}

We searched the Cochrane Tobacco Addiction Group Trials Register, ClinicalTrials.gov, and the International Clinical Trials Registry Platform (ICTRP). The date of the most recent search was March 2018.

\section{Selection criteria}

We included randomised trials of smoking cessation with follow-up of at least six months, where at least one arm tested print-based materials providing self-help compared with minimal print-based self-help (such as a short leaflet) or a lower-intensity control. We defined 'self-help' as structured programming for smokers trying to quit without intensive contact with a therapist.

\section{Data collection and analysis}

We extracted data in accordance with standard methodological procedures set out by Cochrane. The main outcome measure was abstinence from smoking after at least six months' follow-up in people smoking at baseline. We used the most rigorous definition of abstinence in each study and biochemically validated rates when available. Where appropriate, we performed meta-analysis using a random-effects model.

\section{Main results}

We identified 75 studies that met our inclusion criteria. Many study reports did not include sufficient detail to allow judgement of risk of bias for some domains. We judged 30 studies $(40 \%)$ to be at high risk of bias for one or more domains.

Thirty-five studies evaluated the effects of standard, non-tailored self-help materials. Eleven studies compared self-help materials alone with no intervention and found a small effect in favour of the intervention ( $n=13,241$; risk ratio (RR) 1.19 , 95\% confidence interval (CI) 1.03 to $1.37 ; \mathrm{I}^{2}=0 \%$ ). We judged the evidence to be of moderate certainty in accordance with GRADE, downgraded for indirect relevance to populations in low- and middle-income countries because evidence for this comparison came from studies conducted solely 
in high-income countries and there is reason to believe the intervention might work differently in low- and middle-income countries. This analysis excluded two studies by the same author team with strongly positive outcomes that were clear outliers and introduced significant heterogeneity. Six further studies of structured self-help compared with brief leaflets did not show evidence of an effect of selfhelp materials on smoking cessation ( $n=7023$; RR $0.87,95 \% \mathrm{Cl} 0.71$ to $1.07 ; \mathrm{I}^{2}=21 \%$ ). We found evidence of benefit from standard selfhelp materials when there was brief contact that did not include smoking cessation advice (4 studies; $\mathrm{n}=2822 ; \mathrm{RR} 1.39,95 \% \mathrm{Cl} 1.03$ to $1.88 ; I^{2}=0 \%$ ), but not when self-help was provided as an adjunct to face-to-face smoking cessation advice for all participants (11 studies; $\mathrm{n}=5365 ; \mathrm{RR} 0.99,95 \% \mathrm{Cl} 0.76$ to $\left.1.28 ; \mathrm{I}^{2}=32 \%\right)$.

Thirty-two studies tested materials tailored for the characteristics of individual smokers, with controls receiving no materials, or stagematched or non-tailored materials. Most of these studies used more than one mailing. Pooling studies that compared tailored self-help with no self-help, either on its own or compared with advice, or as an adjunct to advice, showed a benefit of providing tailored self-help interventions ( 12 studies; $n=19,190 ; \mathrm{RR} 1.34,95 \% \mathrm{Cl} 1.20$ to $1.49 ; \mathrm{I}^{2}=0 \%$ ) with little evidence of difference between subgroups (10 studies compared tailored with no materials, $\mathrm{n}=14,359$; RR $1.34,95 \% \mathrm{Cl} 1.19$ to $1.51 ; \mathrm{I}^{2}=0 \%$; two studies compared tailored materials with brief advice, $\mathrm{n}=2992 ; \mathrm{RR} 1.13,95 \% \mathrm{Cl} 0.86$ to $1.49 ; \mathrm{I}^{2}=0 \%$; and two studies evaluated tailored materials as an adjunct to brief advice, $\mathrm{n}=1839$; RR $1.72,95 \% \mathrm{Cl} 1.17$ to $\left.2.53 ; \mathrm{I}^{2}=10 \%\right)$. When studies compared tailored self-help with non-tailored self-help, results favoured tailored interventions when the tailored interventions involved more mailings than the non-tailored interventions (9 studies; $n=14,166 ;$ RR 1.42, $95 \% \mathrm{Cl} 1.20$ to $1.68 ; \mathrm{I}^{2}=0 \%$ ), but not when the two conditions were contact-matched (10 studies; $\mathrm{n}=11,024 ; \mathrm{RR} 1.07,95 \% \mathrm{Cl} 0.89$ to 1.30 ; $\left.\mathrm{I}^{2}=50 \%\right)$. We judged the evidence to be of moderate certainty in accordance with GRADE, downgraded for risk of bias.

Five studies evaluated self-help materials as an adjunct to nicotine replacement therapy; pooling three of these provided no evidence of additional benefit ( $n=1769$; RR $1.05,95 \% \mathrm{Cl} 0.86$ to $1.30 ; I^{2}=0 \%$ ). Four studies evaluating additional written materials favoured the intervention, but the lower confidence interval crossed the line of no effect (RR $1.20,95 \% \mathrm{Cl} 0.91$ to $\left.1.58 ; I^{2}=73 \%\right)$. A small number of other studies did not detect benefit from using targeted materials, or find differences between different self-help programmes.

\section{Authors' conclusions}

Moderate-certainty evidence shows that when no other support is available, written self-help materials help more people to stop smoking than no intervention. When people receive advice from a health professional or are using nicotine replacement therapy, there is no evidence that self-help materials add to their effect. However, small benefits cannot be excluded. Moderate-certainty evidence shows that selfhelp materials that use data from participants to tailor the nature of the advice or support given are more effective than no intervention. However, when tailored self-help materials, which typically involve repeated assessment and mailing, were compared with untailored materials delivered similarly, there was no evidence of benefit.

Available evidence tested self-help interventions in high-income countries, where more intensive support is often available. Further research is needed to investigate effects of these interventions in low- and middle-income countries, where more intensive support may not be available.

\section{PLAIN LANGUAGE SUMMARY}

\section{Do printed self-help materials help people to quit smoking?}

\section{Background}

We reviewed the evidence showing how effective printed self-help materials are in helping people to quit smoking. We looked for studies of any type of printed self-help that gave structured support and advice about quitting. This could include any booklets, leaflets, or information sheets that set out some kind of structured programme that someone could follow to help them quit smoking. We also included self-help in audio or video format, but we did not include internet programmes or other formats. We were interested in the number of people who were not smoking for at least six months from the time they were given the self-help materials. Studies had to include people who smoked, but those people did not need to be currently trying to quit smoking.

\section{Study characteristics}

We searched electronic databases for studies that investigated printed self-help. We ran our most recent search in March 2018 , and so far we have found 75 studies. Most studies took place in North America or Europe and were carried out with adults, although they did not require that people wanted to quit smoking to join. Studies delivered self-help materials in person or by post, some all at once, and some spread out over the length of the study. In most studies, self-help was the only support people were given, but some studies tested self-help given with other kinds of support to test whether there was any extra benefit from written self-help. Some studies gathered information about individual smokers, so they could tailor self-help to better help them.

\section{Key results}

Eleven studies including over 13,000 people provided evidence of a small benefit of printed self-help materials when provided on their own. Our confidence in this evidence was only moderate, because these studies took place in high-income countries, which makes them less 
relevant to people from lower-income countries, who might benefit differently. When people used self-help as well as receiving face-to-face advice on how to stop smoking (11 studies), there was no extra benefit compared with the effect of that advice without printed self-help.

Thirty-two studies provided written self-help that was individually tailored, comparing it with either non-tailored self-help or nothing. Evidence based on ten studies including nearly 15,000 people showed that tailored self-help was more helpful than nothing. Our confidence in this evidence is moderate, because some of these studies might have had problems in the ways they were carried out that could have affected the results.

\section{Conclusions}

When no other support is available, written self-help materials help more people to stop smoking compared with getting no help at all. People were more likely to make successful quit attempts when they were also given face-to-face support or nicotine replacement therapy, but printed self-help did not make these people more likely to quit.

Self-help materials that were tailored to help individual people are more effective than no help at all. However, tailoring these materials often involves more contact with the research team, and when we compared tailored self-help with regular self-help that involved the same amount of contact, we did not find a difference in quit rates.

The studies we found looked at self-help given to people in high-income countries, where more intensive support is often available. More research is needed to find out how well self-help works for people in low- and middle-income countries, where more intensive support is less available. 
SUMMARY OF FINDINGS

\section{Summary of findings for the main comparison. Print-based self-help compared to no materials for smoking cessation}

\section{Print-based self-help compared to no materials for smoking cessation}

Patient or population: people who smoke; not selected for interest in quitting smoking

Settings: community - materials provided without personal contact

Intervention: print-based self-help materials

Comparison: no materials

\begin{tabular}{|c|c|c|c|c|c|c|}
\hline \multirow[t]{3}{*}{ Outcomes } & \multicolumn{2}{|c|}{ Illustrative comparative risks ${ }^{\star}(95 \% \mathrm{CI})$} & \multirow{3}{*}{$\begin{array}{l}\text { Relative effect } \\
(95 \% \mathrm{Cl})\end{array}$} & \multirow{3}{*}{$\begin{array}{l}\text { No. of partici- } \\
\text { pants } \\
\text { (studies) }\end{array}$} & \multirow{3}{*}{$\begin{array}{l}\text { Certainty of } \\
\text { the evidence } \\
\text { (GRADE) }\end{array}$} & \multirow[t]{3}{*}{ Comments } \\
\hline & Assumed risk & Corresponding risk & & & & \\
\hline & No materials & $\begin{array}{l}\text { Print-based self-help- } \\
\text { materials }\end{array}$ & & & & \\
\hline \multirow{2}{*}{$\begin{array}{l}\text { Abstinence - non-tai- } \\
\text { lored self-help } \\
\text { Follow-up: } 6+\text { months }\end{array}$} & \multicolumn{2}{|c|}{ Moderate-risk population 1} & \multirow{2}{*}{$\begin{array}{l}\text { RR } 1.19 \\
\text { (1.03 to } 1.37 \text { ) }\end{array}$} & \multirow{2}{*}{$\begin{array}{l}13,241 \\
\text { (11 studies) }\end{array}$} & \multirow{2}{*}{$\begin{array}{l}\oplus \oplus \oplus \ominus \\
\text { moderate }^{2,3}\end{array}$} & \multirow{2}{*}{$\begin{array}{l}\text { No evidence of effect detected in other } \\
\text { studies where the controls received oth- } \\
\text { er materials }(n=6) \text {, or wher all partici- } \\
\text { pants had personal contact }(n=5) \text { or re- } \\
\text { ceived brief advice }(n=11)\end{array}$} \\
\hline & 50 per 1000 & $\begin{array}{l}60 \text { per } 1000 \\
(52 \text { to } 69)\end{array}$ & & & & \\
\hline \multirow{2}{*}{$\begin{array}{l}\text { Abstinence - individu- } \\
\text { ally tailored self-help } \\
\text { Follow-up: } 6+\text { months }\end{array}$} & \multicolumn{2}{|c|}{ Moderate-risk population 1} & \multirow{2}{*}{$\begin{array}{l}\text { RR } 1.34 \\
\text { (1.19 to } 1.51)\end{array}$} & \multirow{2}{*}{$\begin{array}{l}14,359 \\
\text { (10 studies) }\end{array}$} & \multirow{2}{*}{$\begin{array}{l}\oplus \oplus \oplus \ominus \\
\text { moderate }^{4}\end{array}$} & \\
\hline & 50 per 1000 & $\begin{array}{l}\mathbf{8 1} \text { per } \mathbf{1 0 0 0} \\
\text { (71 to } 91)\end{array}$ & & & & \\
\hline
\end{tabular}

$\mathrm{Cl}$ : confidence interval; RR: risk ratio.

GRADE Working Group grades of evidence

High certainty: we are very confident that the true effect lies close to that of the estimate of the effect.

Moderate certainty: we are moderately confident in the effect estimate: the true effect is likely to be close to the estimate of the effect, but there is a possibility that it is substantially different.

Low certainty: our confidence in the effect estimate is limited: the true effect may be substantially different from the estimate of the effect.

Very low certainty: we have very little confidence in the effect estimate: the true effect is likely to be substantially different from the estimate of effect.

${ }^{1}$ Control group success rate based on average across studies. Low rate reflects intervention in participants not selected on basis of motivation to quit. All studies conducted in high-income countries.

2 Most studies at high or unclear risk of bias, but no evidence of differential effect based on risk of bias. Not downgraded.

3Downgraded one level for indirectness: indirectly relevant to populations in low- and middle-income countries because evidence for this comparison came from studies 


\section{B A C K G R O U N D}

\section{Description of the condition}

The World Health Organization has identified tobacco use as the leading behavioural risk factor for preventable premature death (WHO 2012). Globally, tobacco smoking is currently estimated to cause the death of about seven million people a year (WHO 2017). More than $80 \%$ of tobacco-related deaths are projected to occur in low- and middle- income countries (WHO 2012). Adverse health effects from tobacco use include cardiovascular disease, respiratory disease, and cancer.

\section{Description of the intervention}

The aim of self-help interventions is to provide some of the benefits of intensive behavioural interventions without the need to attend treatment sessions. Such materials can be disseminated and used on a much wider scale than therapist-delivered treatment. They therefore represent a bridge between the clinical approach to smoking cessation oriented towards individuals and public health approaches that target populations (Curry 1993). Selfhelp programmes were first developed as written materials, primarily delivered in print, but other formats such as videos and audiotapes have also been used. New technologies enable delivery of information and support via the internet and mobile phones; separate Cochrane Reviews have evaluated these self-help formats (Taylor 2017; Whittaker 2016).

\section{How the intervention might work}

Self-help materials provide structured programmes and advice aimed at helping people to quit smoking by following the programmes therein. These materials and programmes can have a theoretical basis or can be tailored to the individuals trying to quit. Printed self-help materials represent a low-cost intervention with potentially wide reach.

\section{Why it is important to do this review}

Behavioural strategies to aid smoking cessation range from very brief interventions, such as advice from a physician, to intensive multi-component programmes. There is good evidence supporting the effectiveness of brief, therapist-delivered interventions, such as physician advice (Stead 2013a), as well as the additional effect of more intensive behavioural interventions, such as group therapy (Stead 2017), individual counselling (Lancaster 2017), and telephone counselling (Stead 2013b). However, a major limitation of therapist-delivered behavioural interventions is that they reach only a small proportion of smokers. Most successful quitters give up on their own (Lee 2007). Methods to support otherwise unaided quit attempts therefore have the potential to help a far greater proportion of the smoking population. This is especially the case in lower-income countries, where more intensive cessation support may not be available.

Previous reviews and versions of this review have found evidence of a small but significant effect of print-based self-help interventions. However, new theories and technologies have led to continued interest and research in this field. In particular, the ability to tailor materials based on individual characteristics through computerbased algorithms. Such personalisation is the focus of most new research in this field.
The aim of this review is to summarise existing evidence for printbased, video, and audiotape forms of self-help interventions in promoting smoking cessation.

\section{OB JECTIVES}

The aims of this review were to determine the effectiveness of different forms of print-based self-help materials that provide a structured programme for smokers to follow, compared with no treatment and with other minimal contact strategies, and to determine the comparative effectiveness of different components and characteristics of print-based self-help, such as computergenerated feedback, additional materials, tailoring of materials to individuals, and targeting of materials at specific groups.

\section{METHO DS}

\section{Criteria for considering studies for this review \\ Types of studies}

We sought randomised controlled trials with a minimum follow-up of six months, where at least one arm comprised a print-based selfhelp intervention without repeated face-to-face therapist contact compared with another print-based self-help intervention or with a minimal control. We included studies that allocated participants to treatment via a quasi-randomised method, but, where appropriate, we used sensitivity analysis to determine whether inclusion of these studies altered the results.

\section{Types of participants}

We included any smokers except pregnant smokers and adolescent smokers. Separate Cochrane Reviews have evaluated interventions in pregnant smokers (Coleman 2015; Chamberlain 2017), and in adolescent smokers (Fanshawe 2017).

\section{Types of interventions}

We defined a 'self-help intervention' as any manual or programme designed to be used by individuals to assist a quit attempt not aided by health professionals, counsellors, or group support. This review primarily covers written materials such as booklets and leaflets, but information could also have been provided via audio or video or a similar medium. Separate reviews cover interventions designed to be delivered via the internet, or via mobile phone (Taylor 2017; Whittaker 2016). Materials could be aimed at smokers in general; could target particular populations of smokers, for example, those of different ages or ethnic groups; or could be tailored to individual smoker characteristics. We did not include brief leaflets on the health effects of smoking - we considered them to be a control intervention if compared with a more substantial manual. We considered interventions with a single session of minimal face-toface contact for the purpose of supplying the self-help programme materials as self-help alone. Where a face-to-face meeting included discussion of programme content, we categorised this as brief advice in addition to self-help materials. We excluded interventions that provided repeated sessions of advice in addition to self-help materials. Separate Cochrane Reviews cover telephone counselling or hotlines as adjuncts to self-help materials (Stead 2013b), and interventions aimed at relapse prevention (Hajek 2013). 


\section{Types of outcome measures}

We used sustained abstinence, or point prevalence, where available. We included studies that used self-report of cessation alone or biochemically validated cessation.

\section{Search methods for identification of studies}

We identified studies included in previous reviews and metaanalyses, and we searched the Cochrane Tobacco Addiction Review Group Specialised Register of controlled trials for additional studies, using the terms self-help ${ }^{\star}$, manual ${ }^{\star}$, booklet $^{\star}$, or pamphlet $^{\star}$ in the title or abstract, or as a keyword (Appendix 1 ). We conducted the most recent search of the Register in March 2018. At the time of the search, the Register included the results of searches of the Cochrane Central Register of Controlled trials (CENTRAL; 2018, Issue 1) in the Cochrane Library; MEDLINE (via OVID) to update 20180209; Embase (via OVID) to week 201807; and PsycINFO (via OVID) to update 20180212. See the Cochrane Tobacco Addiction Group website for full search strategies and a list of other resources searched.

\section{Data collection and analysis}

Two review authors (JLB and JMOM) extracted data. Information extracted included details of the intervention, population recruited, method of randomisation, completeness of follow-up, way in which cessation was defined, and whether self-reported cessation was validated.

We summarised individual study results as a risk ratio (RR), calculated as: (number of quitters in intervention group/number randomised to intervention group)/(number of quitters in control group/number randomised to control group). Where appropriate, we performed meta-analysis using a Mantel-Haenszel randomeffects method to estimate a pooled risk ratio with $95 \%$ confidence intervals $(\mathrm{Cl})$. We estimated statistical heterogeneity between studies using the $\mathrm{I}^{2}$ statistic (Higgins 2003). Values between $30 \%$ and $60 \%$ may suggest moderate heterogeneity, and values over $75 \%$ represent considerable heterogeneity (Higgins 2011).

We categorised studies according to the amount of face-to-face contact provided to both treatment and comparison intervention groups, whether or not any written materials were given to the comparison group, and whether the material was individually tailored. Comparison tables included the following.

- Non-tailored self-help materials versus no treatment or a leaflet only, without face-to-face contact.

- Non-tailored self-help materials versus no treatment or a leaflet only, with face-to-face contact.

- Non-tailored self-help materials and brief advice versus brief advice alone.

- Individually tailored materials versus no materials.

- Individually tailored versus standard or stage-matched materials.

- Self-help materials plus nicotine replacement therapy (NRT) versus NRT alone.

A Cochrane Review on individual counselling covered any studies comparing self-help to individual counselling (Lancaster 2017). The Cochrane Review on group therapy for smoking cessation covered self-help versus group counselling (Stead 2017). Self-help plus NRT versus self-help alone is a test of the efficacy of NRT; a Cochrane Review on NRT versus control covers this topic (Hartmann-Boyce 2018).

Comparison tables also addressed the following enhancements and adjuncts to self-help.

- Tailored self-help programmes versus non-tailored programmes, or no-intervention controls.

- Targeted materials versus standard materials.

- Provision of additional materials.

- Different self-help programmes or different media formats (e.g. audio, video) compared to each other.

We define 'tailored materials' as those that make use of participant characteristics to provide individualised programmes. We also include in this category interventions providing individual written feedback in addition to standard materials. We define 'targeted materials' as those tailored for a broadly defined category of smokers, for example, women with young children, older smokers, or smokers at a particular stage of change (Kreuter 2000).

Earlier versions of this review included telephone counselling and relapse prevention interventions. A separate Cochrane Review evaluated the use of proactive telephone counselling or provision of telephone hotlines as an adjunct to self-help materials (Stead 2013b), so we did not include in this review studies that compare only these interventions. Likewise, Hajek 2013 evaluated interventions aiming to prevent relapse, so we have no longer included them in this review.

\section{'Summary of findings' table}

We created a 'Summary of findings' table for our primary outcomes, in accordance with standard Cochrane methods. We used the five GRADE considerations (study limitations, consistency of effect, imprecision, indirectness, and publication bias) to assess the certainty of evidence for each outcome.

\section{RES ULTS}

\section{Description of studies}

For the present update of this review, we identified 491 potentially relevant records new to the Tobacco Addiction Group Specialised Register since the last update; three new studies met the inclusion criteria (Figure 1). The review now includes 75 studies of selfhelp methods. We treated one study with a factorial design as two studies for data entry purposes (Killen 1997; Killen 1997 +NP). Thirty-four of the included studies compared standard self-help materials with no intervention or provided standard materials as an adjunct to advice. The other studies compared targeted or tailored self-help methods or compared other variations of programmes. Some studies used multiple interventions, testing the effects of different types of information or of increasing amounts of material. Studies of self-help materials were carried out in a range of settings. Some studies provided the materials without face-to-face contact or any additional motivating strategy. Some studies tested the use of materials for people who had called quitlines (self-help materials were the main form of support offered) or the use of materials as an adjunct to counselling (Strecher 2005). In healthcare settings, studies more frequently provided self-help materials as an adjunct to brief advice to quit. Some studies described as testing self-help 
materials included relatively high levels of face-to-face support,

although less than in formal counselling programmes. Most studies did not specify an interest in quitting as a selection criterion.

Figure 1. Flow diagram for 2018 update.

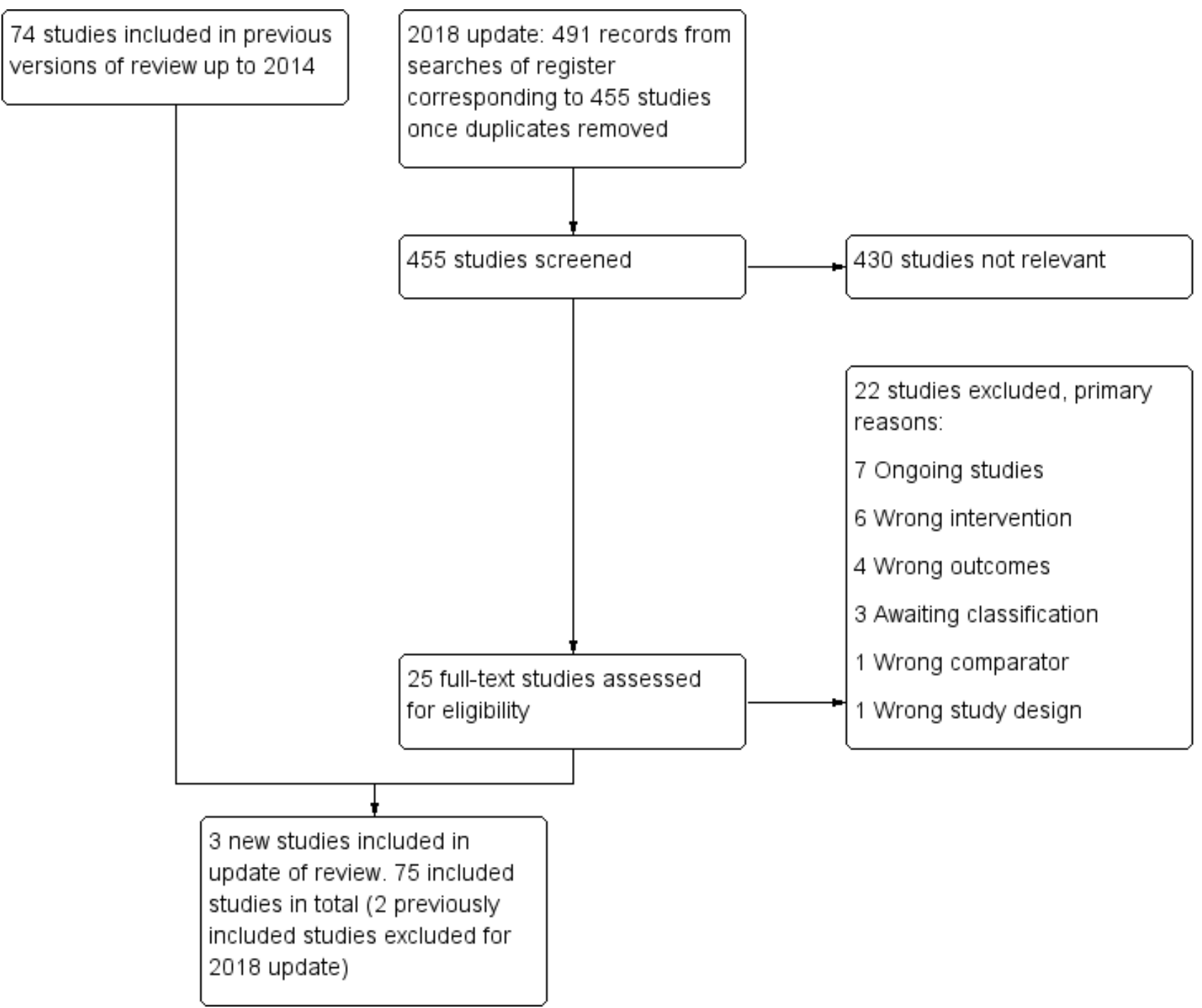

The content and format of the self-help programmes varied. The most frequently used materials were the American Lung Association (ALA) cessation manual: Freedom from Smoking in 20 days, and the maintenance manual: A Lifetime of Freedom from Smoking. Most other programmes were not named or described fully. Materials have tended to become more complex over time and to incorporate more techniques from behaviour therapy approaches. Most recent studies have used computerised expert systems to provide tailored materials judged to be relevant to the characteristics of each smoker, using baseline data. We specified that materials should contain a structured programme for quitting. When it was not clear whether the materials provided met these criteria, we performed sensitivity analysis to determine the effects of including or excluding these studies.

Fraser 2014 factorially tested combinations of 'on' and 'off' versions of five interventions: the National Cancer Institute website versus a 'lite' website, telephone counselling versus no counselling, a selfhelp manual versus a brief brochure, motivational email messages versus no messages, and nicotine replacement therapy (NRT) versus no NRT. We were interested in two comparisons from this study. The first compared the arm comprising the 'off' version of each intervention except the self-help manual with the arm comprising the 'off' version of every intervention. The second compared the arm comprising the 'off' version of each intervention except the self-help manual and NRT with the arm comprising the 'off' version of each intervention except NRT. Unfortunately the study report did not report abstinence rates for these comparisons, and when we contacted the study author team, we received no response. As such, we were unable to include this study in the relevant meta-analyses.

Further details on each of the included studies can be found in the Characteristics of included studies tables. Details of 79 studies excluded at full-text stage can be found in the Characteristics of excluded studies tables. The most common reasons for listing studies as excluded are that study authors used self-help materials as the control, and follow-up was too short - typically only one

Print-based self-help interventions for smoking cessation (Review) 
month. We previously included Killen 1990 and Fortmann 1995 in this review, but we excluded them from this update on the grounds that they are studies of relapse prevention and are now included in another Cochrane Review (Hajek 2013). Details of seven ongoing studies and three studies for which there was insufficient information to include or exclude are presented in the Characteristics of ongoing studies and Characteristics of studies awaiting classification tables respectively.

\section{Non-tailored self-help materials compared to no intervention (Comparisons 1 and 2)}

\section{Non-tailored materials without face-to-face contact}

We identified 20 studies that sent non-tailored self-help materials to smokers without any personal contact. Thirteen of these sent no materials to the comparison control group (Cuckle 1984; Ledwith 1984; Lando 1991; Gritz 1992; Pallonen 1994; Curry 1995; Humerfelt 1998; Dijkstra 1999; Schofield 1999; Becona 2001a; Becona 2001b; Lennox 2001; Willemsen 2006). In the other seven studies, the control group received a brief leaflet (Davis 1984; Cummings 1988; Orleans 1991; Lichtenstein 2000; Lichtenstein 2008; Fraser 2014; Parekh 2014). In 11 studies, participants responded to promotion of smoking cessation programmes or volunteered for a trial. One of these recruited only smokers who were not planning to quit in the next six months (Dijkstra 1999). Two studies sent unsolicited materials to smokers in health maintenance organisations (Gritz 1992; Curry 1995). One sent either tailored or non-tailored letters from a physician to general practice patients who had answered a questionnaire about smoking behaviour (Lennox 2001); we compared the standard letter with the non-intervention control in this comparison. One study addressed smoking, diet, physical activity, and weight, so only a subgroup of participants smoked the control group received information on other health behaviours (Parekh 2014). One study sent a booklet and a personally addressed letter from a consultant to smokers or recent quitters discharged from hospital (Schofield 1999). Three studies targeted factors that might motivate interest in quitting. One of these used a community survey to identify young (aged 30 to 45 years) male smokers with reduced forced expiratory volume in one second $\left(\mathrm{FEV}_{1}\right)$ or asbestos exposure. The intervention consisted of self-help materials accompanied by a letter from a respiratory physician, which drew attention to the individual's higher risk of smoking-related lung disease and advised quitting (Humerfelt 1998). Two recruited households via a utility bill enclosure offering radon testing, and provided a leaflet (Lichtenstein 2000) or video (Lichtenstein 2008) that highlighted the synergistic impact of radon and smoking and advised on quitting or not smoking indoors. The comparison groups received a standard leaflet about the risks of radon that did not emphasise quitting. Fraser 2014 recruited people visiting a quit smoking website. All but four studies used a single mailing of materials. Becona 2001a and one arm of Becona 2001b sent six weekly mailings; Pallonen 1994 sent stage of change-based manuals at six-monthly intervals; one arm of Parekh 2014 received a second assessment and mailing after three months.

Fraser 2014 comprised 32 arms testing combinations of 'on' and 'off' versions of five interventions and included a comparison of self-help materials with a minimal brochure. However, because of insufficient data, we were unable to include this study in the analysis.

\section{Non-tailored materials with brief contact}

We identified four studies in which investigators gave non-tailored self-help materials personally to participants, but not in the context of formal advice to stop smoking. One study gave the control group health education materials without a specific focus on tobacco use, and intended to give the intervention group a single telephone call (Resnicow 1997). In the other studies, controls received no intervention (Prue 1983; Campbell 1986; Betson 1998). Three studies recruited in outpatient clinics (Prue 1983; Campbell 1986; Betson 1998); the last of these probably included some telephone contact for the self-help group, although the extent of this is unclear. Resnicow 1997 recruited in healthcare, church, and public housing settings.

\section{Non-tailored materials and advice versus advice alone}

Eleven studies assessed non-tailored self-help materials as an adjunct to brief advice about stopping smoking given by a healthcare worker. Three of these studies gave some written materials to the control group. Lando 1988 prescribed nicotine gum to both arms and gave instructions on its use. A doctor alone gave advice in six studies, and a doctor, nurse, or both gave advice in four. In Davies 1992, student nurses advised two smokers each - one before and one after training - to deliver a self-help manual. Hollis 1993 provided self-help participants with additional advice from a nurse, as well as a physician message. In a study of physician advice that used a complete factorial design, some participants received structured advice with or without materials, and some received brief advice - we have combined the two levels of advice (Thompson 1988). Kottke 1989 randomised physicians to a workshop with or without a supply of self-help materials for their patients.

We did not identify any studies that directly compared standard self-help materials with brief advice.

\section{Tailored self-help materials (Comparisons 3 and 4)}

Thirty-two studies used materials tailored to the characteristics of individual smokers. Only two of these provided any face-toface contact as part of the baseline intervention (Lipkus 1999; Meyer 2012). Four recruited people who had called a quitline. Borland 2003 recruited only those callers seeking written materials without counselling. Borland 2004 provided brief counselling to some participants before recruitment, and Strecher 2005 and Sutton 2007 ensured that all participants received counselling during their initial call. Just under half of the remaining studies included volunteers who were likely to have been seeking help to quit. Fifteen recruited a mix of people, some of whom were not interested in immediate quit attempts (Velicer 1999; Curry 1995; Lennox 2001; Prochaska 2001a; Prochaska 2001b; Etter 2004; Aveyard 2003; Prochaska 2004; Prochaska 2005; de Vries 2008; Schumann 2008; Meyer 2012; van der Aalst 2012; Gilbert 2013; Parekh 2014). Dijkstra 1999 specifically recruited people not interested in quitting, and Meyer 2016 recruited people not interested in quitting in the next six months. Four studies evaluated multiple risk factor interventions, so only a subgroup of participants smoked (Prochaska 2004; Prochaska 2005; de Vries 2008; Parekh 2014).

Ten studies compared tailored materials with no intervention (Dijkstra 1998b; Prochaska 2001a; Prochaska 2001b; Etter 2004; Prochaska 2004; Prochaska 2005; Meyer 2008; Schumann 2008; Hoving 2010; Meyer 2016). Some of the 19 studies testing the 
incremental effect of tailoring over standard materials confounded the tailoring with additional contact, so we grouped these studies according to whether or not the number of mailings was matched. Ten studies matched contacts (Burling 1989; Owen 1989; Velicer 1999; Becona 2001a; Lennox 2001; Strecher 2005; Velicer 2006; Sutton 2007; de Vries 2008; van der Aalst 2012). Among studies with additional contacts, some provided the same materials initially but then provided additional tailored materials to the intervention group; six tailored all materials (Curry 1991; Prochaska 1993; Curry 1995; Aveyard 2003; Borland 2003; Gilbert 2013), and three tailored materials only in part (Ledwith 1984; Dijkstra 1999; Borland 2004). Two studies tested tailored materials as an adjunct to advice (Lipkus 1999; Meyer 2012). Webb 2013 compared a placebo tailored intervention (tailoring was not actually conducted, but materials were constructed to suggest it had been) with a standard, nontailored intervention.

The method used for obtaining information, the theoretical basis for tailoring materials, the materials provided, and the number of contacts, all varied, and are reported in more detail in the Characteristics of included studies tables. Ten studies tailored materials based only on information provided at baseline (Ledwith 1984; Owen 1989; Dijkstra 1998a; Curry 1995; Lennox 2001; Strecher 2005; Sutton 2007; de Vries 2008; Hoving 2010; van der Aalst 2012), whereas the others sent further materials based on further assessments. Of those interventions that reported the theoretical basis for tailoring, stage of change was by far the most commonly used model, with 15 interventions modelling material on this theory (Pederson 1983; Velicer 1999; Lennox 2001; Prochaska 2001a; Prochaska 2001b; Aveyard 2003; Borland 2003; Etter 2004; Prochaska 2004; Prochaska 2005; Velicer 2006; Meyer 2008; Schumann 2008; Meyer 2012; Meyer 2016). Sutton 2007 tailored materials based on social-cognitive and perspectives of change theories, and two studies based their intervention on the I-change model (Dijkstra 1998a; Hoving 2010). Most tailored interventions provided materials at multiple time points.

\section{Self-help and nicotine replacement therapy (NRT) compared to NRT alone (Comparison 5)}

Lando 1988 tested non-tailored self-help materials as an adjunct to nicotine replacement. Fraser 2014 comprised 32 arms testing combinations of 'on' and 'off' versions of five interventions and included a comparison of self-help materials plus NRT with a minimal brochure plus NRT. However, because of insufficient data, we were unable to include the study in our analysis. We also excluded ICRF 1994 from this comparison because both groups received written materials that we classified as self-help. For this update, we excluded a study previously included in the review for this comparison because the intervention was targeted at relapse prevention (Fortmann 1995).

Two studies tested tailored/targeted self-help materials as an adjunct to NRT. One study, published as an abstract (Orleans 2000), used a guide targeted for older smokers and seven age-tailored computer-generated mailings as an adjunct to nicotine patches. The control group received a fact sheet on patch-assisted quitting. Velicer 2006 tested a single tailored letter as an adjunct to stagebased manuals and nicotine patches for people identified as ready to quit.

\section{Other enhancements or adjuncts to self-help materials (Comparison 6)}

\section{Additional written materials}

Four studies examined the effect of further mailings of non-tailored materials. Owen 1989 compared a quit kit and five-day cessation plan with a staged correspondence course. McFall 1993 tested the American Lung Association (ALA) manual: Freedom from Smoking in 20 Days, used in conjunction with a televised programme, compared with additional maintenance newsletters and with the manual or programme alone. Cuckle 1984 mailed the materials six months after the quit kit. Brandon 2016 tested two programmes of additional written materials compared with a single mailing. One arm received 19 mailings over 18 months from baseline, and one received eight mailings over 12 months. We added each arm to the meta-analysis separately.

\section{Additional video}

Killen 1997 tested a video as an additional component. Using a factorial design, investigators also tested the effect of nicotine patches, and because there was evidence of an interaction between the NRT and the self-help condition, we entered the patch and placebo arms separately.

\section{Materials targeted at particular populations of smokers}

Five studies compared a manual targeted at a particular population with a standard one. Davis 1992 compared a programme intended for mothers of young children with ALA or National Cancer Institute $(\mathrm{NCl})$ materials. Orleans 1998 compared a guide addressing the quitting needs and barriers of African American smokers with a standard guide that was mailed to smokers calling the $\mathrm{NCl}$ Cancer Information Service. Prochaska 1993 provided manuals tailored to smokers' stage of change compared to standard materials. We excluded another study of manuals tailored to older smokers because no long-term follow-up has been reported (Rimer 1994). Nollen 2007 compared culturally sensitive materials with standard materials for African American smokers, who also received nicotine patches and two phone calls.

\section{Comparisons between different types of self-help materials}

We identified eight studies that compared different types of self-help materials that were neither tailored nor personalised, or were delivered over different time periods (Glasgow 1981; Omenn 1988; ICRF 1994; Berman 1995; Becona 2001b; Sykes 2001; Clark 2004; Smith 2004). Two of these studies compared three different sets of materials (Glasgow 1981; Omenn 1988). ICRF 1994 compared a standard 16-page booklet with a larger manual containing more information about quitting with the use of nicotine patches. Berman 1995 compared two types of materials for smokers volunteering for heart health screening and smoking cessation. Becona 2001b compared a manual with a weekly mailing of six booklets, both based on the same cognitive-behavioural approach. Sykes 2001 compared a cognitivebehavioural programme consisting of a handbook, reduction cards, a progress chart, and an audiotape that summarised the programme and provided relaxation music, with a leaflet developed by the UK Health Education Authority, both used as an adjunct to a single introductory session in a group format. Clark 2004 tested a handout listing internet sites providing useful resources, compared with standard self-help materials. Smith 2004 compared a 44-page booklet produced by the Canadian Cancer 
Society with a single-page advice pamphlet. These were tested using a factorial design, along with telephone counselling of two different intensities (which we collapsed for this review).

\section{Risk of bias in included studies}

Figure 2 shows risk of bias judgements for each included study. We have summarised judgements by domain below. We judged
30 studies to be at high risk of bias in at least one domain, 37 to be at unclear risk of bias in at least one domain and not high in any domain, and eight studies to be at low risk of bias across all domains. 
Figure 2. Risk of bias summary: review authors' judgements about each risk of bias item for each included study.

\begin{tabular}{|c|c|c|c|c|c|}
\hline & 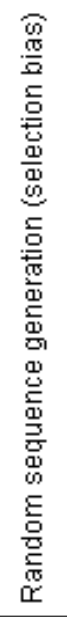 & 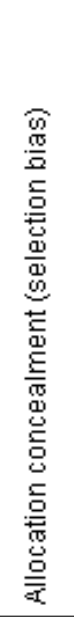 & 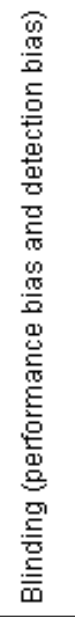 & 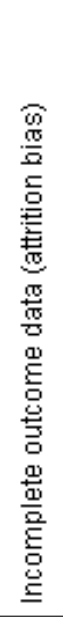 & 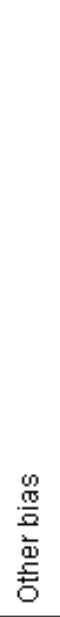 \\
\hline Aveyard 2003 & $\odot$ & 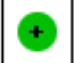 & $\odot$ & $\odot$ & \\
\hline Becona 2001a & $?$ & $?$ & $\Theta$ & + & \\
\hline Becona 2001b & $?$ & $?$ & $\Theta$ & $?$ & \\
\hline Berman 1995 & $\odot$ & 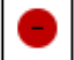 & + & + & \\
\hline Betson 1998 & $?$ & $?$ & $?$ & $\odot$ & \\
\hline Borland 2003 & $\Theta$ & $?$ & + & $\odot$ & \\
\hline Borland 2004 & + & + & + & $\odot$ & \\
\hline Brandon 2016 & + & $\oplus$ & $?$ & $\odot$ & \\
\hline BTS 1983 & $\odot$ & $\oplus$ & $?$ & + & \\
\hline Burling 1989 & $?$ & $?$ & $\odot$ & $\odot$ & \\
\hline Campbell 1986 & $\ominus$ & 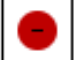 & + & + & \\
\hline Clark 2004 & $?$ & $?$ & + & $?$ & \\
\hline Cuckle 1984 & $?$ & $?$ & $\odot$ & $\odot$ & \\
\hline Cummings 1988 & $?$ & $?$ & $\odot$ & $\odot$ & \\
\hline Curry 1991 & $?$ & $?$ & $?$ & $?$ & \\
\hline Curry 1995 & $?$ & $?$ & - & + & \\
\hline Davies 1992 & $?$ & $?$ & $\theta$ & $\odot$ & \\
\hline Davis 1984 & $?$ & $?$ & + & $?$ & \\
\hline Davis 1992 & $\Theta$ & $\odot$ & $\odot$ & $\odot$ & \\
\hline de Vries 2008 & $?$ & $?$ & + & $\odot$ & \\
\hline Dijkstra 1998a & $?$ & $?$ & $\Theta$ & + & \\
\hline Dijkstra 1999 & $?$ & $?$ & $?$ & $\odot$ & \\
\hline
\end{tabular}


Figure 2. (Continued)

\begin{tabular}{|c|c|c|c|c|}
\hline Dijkstra 1999 & $?$ & $?$ & $?$ & $\odot$ \\
\hline Etter 2004 & + & $?$ & $\odot$ & 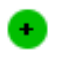 \\
\hline Fraser 2014 & $?$ & $\odot$ & $\Theta$ & $\odot$ \\
\hline Gilbert 2013 & $\oplus$ & $\odot$ & $\Theta$ & $\odot$ \\
\hline Glasgow 1981 & $?$ & $?$ & $\oplus$ & $\odot$ \\
\hline Gritz 1992 & $?$ & $?$ & + & + \\
\hline Harackiewicz 1988 & ? & $?$ & + & $\odot$ \\
\hline Hollis 1993 & - & - & $?$ & + \\
\hline Hoving 2010 & $\Theta$ & $\odot$ & ? & $?$ \\
\hline Humerfelt 1998 & $?$ & $?$ & + & + \\
\hline ICRF 1994 & + & $\odot$ & + & + \\
\hline Janz 1987 & $\Theta$ & $?$ & + & + \\
\hline Killen 1997 & ? & $?$ & ? & ? \\
\hline Killen $1997+N P$ & & & & \\
\hline Kottke 1989 & $\Theta$ & - & + & + \\
\hline Lando 1988 & $?$ & $?$ & + & ? \\
\hline Lando 1991 & $?$ & $?$ & $\Theta$ & + \\
\hline Ledwith 1984 & ? & $?$ & + & $?$ \\
\hline Lennox 2001 & + & $\odot$ & + & $\odot$ \\
\hline Lichtenstein 2000 & $?$ & $?$ & + & + \\
\hline Lichtenstein 2008 & $\Theta$ & ? & + & + \\
\hline Lipkus 1999 & ? & ? & ? & + \\
\hline McFall 1993 & ? & $?$ & ? & $\odot$ \\
\hline Meyer 2008 & - & - & $?$ & + \\
\hline Meyer 2012 & - & C & - & + \\
\hline Meyer 2016 & + & + & ? & - \\
\hline Nollen 2007 & + & $?$ & + & $\Theta$ \\
\hline Omenn 1988 & + & $?$ & + & + \\
\hline Orleans 1991 & $?$ & $?$ & + & + \\
\hline Orleans 1998 & + & $\odot$ & - & + \\
\hline Orleans 2000 & $?$ & $?$ & $?$ & + \\
\hline
\end{tabular}


Figure 2. (Continued)

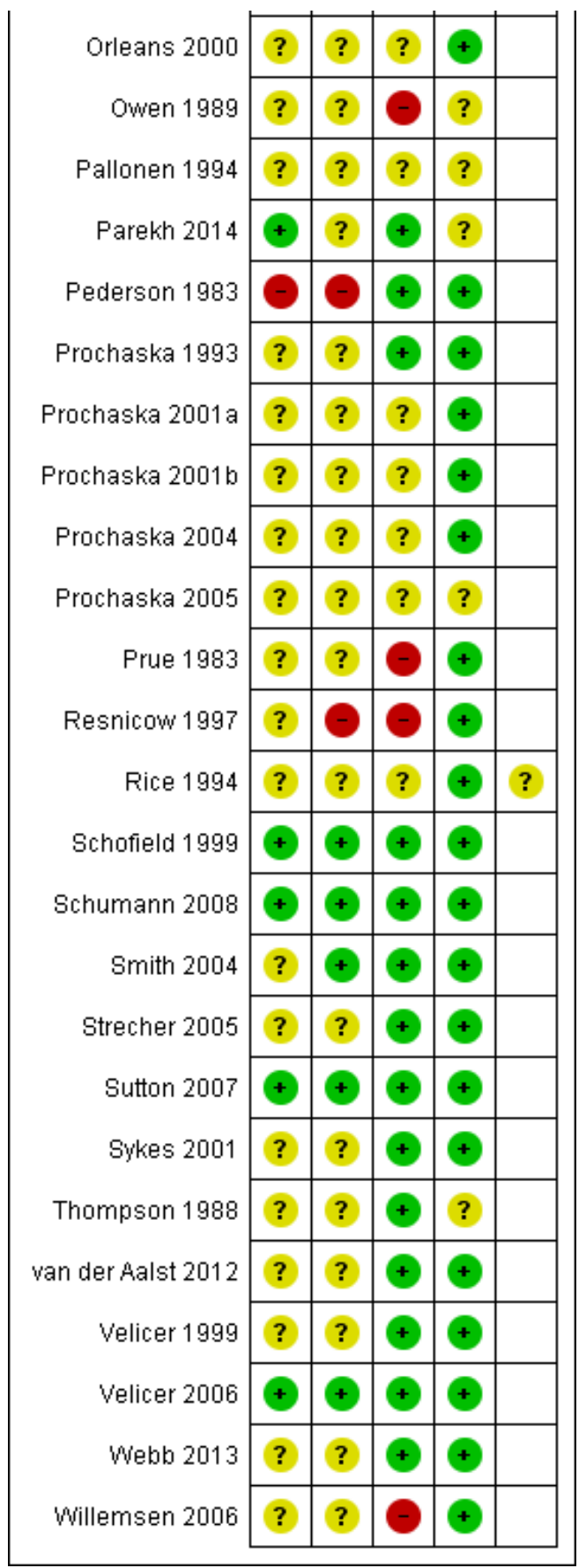

\section{Allocation}

Only 11 study reports provided full descriptions of randomisation and allocation concealment methods that we judged to have low risk of bias (BTS 1983; ICRF 1994; Schofield 1999; Lennox 2001; Aveyard 2003; Borland 2004; Smith 2004; Velicer 2006; Sutton 2007; Schumann 2008; Gilbert 2013). Most studies did not explicitly describe the way in which the randomisation sequence was generated or concealed until participant enrolment. Many studies provided no face-to-face contact with participants, and the likelihood of biased allocation was probably low. Four studies used a pseudo-random method of allocation by day or week of attendance (Pederson 1983; Campbell 1986; Davis 1992; Meyer 2008), and Hollis 1993 used numbers in the patient record. Borland 2003 shuffled questionnaires, and Hoving 2010 used the preprinted colour on the questionnaire to determine allocation. Kottke 1989 randomised physicians to intervention groups, and two studies randomised households (Lichtenstein 2000; Lichtenstein 2008). Three studies randomised by recruitment site (Berman 1995; Resnicow 1997; Meyer 2012). For some studies, we judged that the method of generating the allocation could have led to selection bias in the recruitment or assignment of participants. Excluding studies that we judged to be at risk of bias due to an inadequate method of allocation did not alter the conclusions from any meta-analysis. 


\section{Blinding}

For this update, we assessed performance and detection bias based on blinding of participants and personnel and on whether biochemical validation was used. Forty-two studies provided details of blinding, biochemical validation, and/or description of interventions of similar intensity that led us to judge them to be at low risk of bias in this domain. Fifteen studies described procedures that we judged to place the results at high risk of bias in this domain (Prue 1983; Cuckle 1984; Owen 1989; Lando 1991; Davies 1992; Curry 1995; Resnicow 1997; Dijkstra 1998a; Orleans 1998; Becona 2001a; Becona 2001b; Etter 2004; Willemsen 2006; Meyer 2012; Gilbert 2013; Fraser 2014), and the remainder did not provide sufficient detail with which to judge; hence we judged them to be at unclear risk of performance and detection bias.

Twenty-three studies undertook biochemical validation of all selfreports of quitting, or provided sufficient data to adjust quit rates for the level of misreport in a sample (Glasgow 1981; BTS 1983; Cuckle 1984; Campbell 1986; Harackiewicz 1988; Omenn 1988; Burling 1989; Kottke 1989; Curry 1991; Orleans 1991; Davies 1992; Hollis 1993; ICRF 1994; Killen 1997; Humerfelt 1998; Schofield 1999; Sykes 2001; Becona 2001a; Lennox 2001; Aveyard 2003; Clark 2004; Nollen 2007; Webb 2013). In three cases, a significant other confirmed quitting (Prue 1983; Cummings 1988; Davis 1992). Amongst those that did not report fully biochemically verified quit rates, 15 studies used self-reported abstinence at a single follow-up point (Pederson 1983; Prue 1983; Janz 1987; Thompson 1988; Owen 1989; Lando 1991; Resnicow 1997; Orleans 1998; Dijkstra 1999; Lipkus 1999; de Vries 2008; Hoving 2010 (GP arms only); Gilbert 2013; Meyer 2012; Parekh 2014 (single arms only)). In the other studies without validation, participants classified as non-smokers had reported sustained abstinence or had been abstinent at one or more points before final follow-up.

\section{Incomplete outcome data}

Some reports give quit rates based only on those people contacted at follow-up. In this review, we have followed the methods of the Cochrane Tobacco Addiction Review Group in reporting analyses based on the total number randomised wherever possible, with dropouts and participants lost to follow-up classified as smokers. It has been argued in population-based studies that it may be pessimistic, and may introduce bias, to classify all dropouts as continuing smokers if those data are missing at random (Velicer 1999). We have noted in the 'Risk of bias' tables the number of dropouts by group, and whether the data used in this review included all randomised participants. Where the proportion of dropouts was high and differed across treatment conditions, we performed sensitivity analyses to assess whether excluding dropouts would affect the conclusions. It should be noted that if the proportion of dropouts is similar across conditions, including losses as treatment failures does not affect the risk ratio. A large majority of included studies reported sufficiently similar losses to follow-up across arms that we judged them to be at low risk of attrition bias. Thirteen did not provide sufficient detail with which to judge, and four reported data on loss to follow-up that led us to place these studies at high risk of bias in this domain: Nollen 2007 successfully followed up on less than half of participants; two studies reported follow-up substantially different between intervention and control arms (Cuckle 1984; Meyer 2016); and de Vries 2008 reported only participants who provided data at final follow-up.

\section{Measures of abstinence}

Studies reported a range of measures of abstinence. A minimum follow-up period of six months was required for inclusion in this review, but 47 of $75(62.7 \%)$ followed up on participants for 12 months or longer. Thirty-four of these required abstinence to be sustained for a period. Studies that used strict criteria for self-reported sustained abstinence, with validation at one or more follow-up points, tended to report lower quit rates for both experimental and comparison interventions. In minimal contact programmes, researchers often reported that obtaining saliva samples for biochemical validation was a problem. Participants may have declined to provide samples for reasons unrelated to their smoking status. Validated quit rates therefore may be particularly low and are likely to underestimate success rates if all those for whom samples are not available are classified as smokers. Measures using abstinence from the first follow-up may underestimate the long-term effect of having access to the selfhelp materials, which may prompt a quit attempt some time after they were supplied. Studies with long follow-up that use only point prevalence abstinence rates may show a trend toward increasing quit rates as more smokers make attempts over time.

\section{Effects of interventions}

See: Summary of findings for the main comparison Print-based self-help compared to no materials for smoking cessation

Studies varied in the amount of face-to-face contact given with both experimental and comparison interventions, and in whether or not control materials were given to smokers in the comparison group. In considering the effects of self-help, we grouped studies by these categories. For Comparison 1, we calculated a pooled risk ratio (RR) separately for each level of personal contact with subgroups for the type of control. For Comparison 2, we used the same study data and pooled all subgroups to estimate an overall pooled RR from all studies comparing self-help with no self-help.

\section{Non-tailored self-help materials compared to no intervention (Comparisons 1 and 2)}

\section{Non-tailored materials without face-to-face contact}

Thirteen studies with a total of over 15,500 participants provided standard non-tailored self-help manuals or materials by post; control groups received no materials. Substantial heterogeneity $\left(I^{2}\right.$ $=71 \%$ ) was attributable to the inclusion of two studies conducted in Spain that showed very strong effects (Analysis 1.2) (Becona 2001a; Becona 2001b). Both studies enrolled treatment-seeking smokers, and those in the control group knew they would be offered treatment after six months - a possible disincentive to making an unaided quit attempt. Quit rates were also very high in the intervention groups (16\% and $25 \%$ ). We have therefore excluded these studies from this meta-analysis and calculated a pooled estimated effect for the other 11 studies, amongst which we found no evidence of heterogeneity $\left(I^{2}=0 \%\right)$. Our meta-analysis also excluded Fraser 2014, for which we were unable to access sufficient data; however, the study report suggests that no significant effect was detected for a standard self-help brochure compared to no intervention. Amongst the studies included in our meta-analysis, the control quit rate ranged from $1 \%$ to $11 \%$, with an average of $5 \%$, and the intervention quit rate ranged from $2 \%$ to $10 \%$. The pooled risk ratio favoured self-help interventions, although the confidence 
interval $(\mathrm{Cl})$ only narrowly excluded $1.0(\mathrm{n}=13,241$; risk ratio (RR) $1.19,95 \% \mathrm{Cl} 1.03$ to $1.37 ; \mathrm{I}^{2}=0 \%$; Analysis 1.1 .1 /Analysis 2.1 .1 ).

Six studies provided controls with some form of written materials and did not show benefit of more structured materials $(n=7023$; RR $0.87,95 \% \mathrm{Cl} 0.1$ to $1.07 ; I^{2}=21 \%$; Analysis 1.1.2/Analysis 2.1.2). Pooling these two subgroups does not demonstrate benefit of selfhelp materials ( $n=20,264$; RR $1.05,95 \% \mathrm{Cl} 0.92$ to $\left.1.20 ; I^{2}=26 \%\right)$.

\section{Non-tailored materials with brief contact}

Four studies including almost 3000 participants delivered materials in person rather than by post. The average control group quit rate was $4.7 \%$. Results show no evidence of heterogeneity, and whilst we failed to find evidence of a significant effect of self-help materials given with face-to-face contact when subgrouped based on whether or not controls received some written materials, the pooled result of all four studies did provide evidence of an effect ( $\mathrm{n}$ = 2822; RR 1.39, 95\% Cl 1.03 to $1.88 ;\left.\right|^{2}=0 \%$; Analysis 1.3 ).

\section{Non-tailored materials and advice versus advice alone}

Eleven studies with a total of over 5000 participants tested self-help materials as an adjunct to face-to-face advice from a healthcare provider. We noted little heterogeneity and found no evidence that the additional self-help materials significantly increased quit rates ( $\mathrm{n}=5365$; RR $0.99,95 \% \mathrm{Cl} 0.76$ to $1.28 ; \mathrm{I}^{2}=32 \%$; Analysis 1.4 ). Whether or not the control group received materials did not affect the estimate. Control group quit rates ranged from $2 \%$ to $25 \%$ with an average of $7 \%$. As would be expected, this is higher than the rates seen in control groups that received no intervention.

\section{Overall effect of non-tailored self-help, alone or as adjunct to advice}

When we pooled 32 studies of self-help materials compared to no self-help, irrespective of the level of contact and support common to the control group, the point estimate showed a small benefit of the intervention but the confidence interval included the possibility of no difference ( $n=28,451$; RR $1.06,95 \% \mathrm{Cl} 0.95$ to $1.19 ; I^{2}=25 \%$; Analysis 2.1; Figure 3). (Note: the estimate excludes Becona 2001a, Becona 2001b, and Fraser 2014. Betson 1998 contributes data to two subgroups.) 
Figure 3. Forest plot of comparison: 2 Self-help vs no self-help, pooling all studies, outcome: 2.1 Long-term abstinence.

$\begin{array}{llll}\text { Treatment } & \text { Control } & \text { Risk Ratio } & \text { Risk Ratio }\end{array}$

Study or Subgroup Events Total Events Total Weight M-H, Random, 95\% Cl 2.1.1 No contact/No materials for control

$\begin{array}{lrrrrr}\text { Cuckle 1984 } & 58 & 643 & 50 & 719 & 5.8 \% \\ \text { Curry 1995 } & 7 & 330 & 9 & 328 & 1.2 \% \\ \text { Dijkstra 1999 } & 7 & 215 & 10 & 208 & 1.3 \% \\ \text { Gritz 1992 } & 21 & 602 & 12 & 617 & 2.2 \% \\ \text { Humerfelt 1998 } & 93 & 1300 & 80 & 1310 & 7.4 \% \\ \text { Lando 1991 } & 37 & 388 & 17 & 157 & 3.3 \% \\ \text { Ledwith 1984 } & 9 & 481 & 6 & 459 & 1.1 \% \\ \text { Lennox 2001 } & 37 & 869 & 22 & 871 & 3.6 \% \\ \text { Pallonen 1994 } & 15 & 149 & 7 & 116 & 1.5 \% \\ \text { Schofield 1999 } & 107 & 1246 & 92 & 1219 & 7.9 \% \\ \text { Willemsen 2006 } & 25 & 500 & 26 & 514 & 3.4 \% \\ \text { Subtotal (95\% Cl) } & & \mathbf{6 7 2 3} & & \mathbf{6 5 1 8} & \mathbf{3 8 . 8} \% \\ \text { Total events } & 416 & & 331 & & \end{array}$

Heterogeneity: $\mathrm{Tau}^{2}=0.00 ; \mathrm{Chi}^{2}=7.85, \mathrm{df}=10(\mathrm{P}=0.64) ; \mathrm{I}^{2}=0 \%$

Test for overall effect: $Z=2.38(P=0.02)$

\subsubsection{No contact/Leaflet for control}

$\begin{array}{lrrrrr}\text { Cummings 1988 } & 46 & 1030 & 34 & 486 & 4.7 \% \\ \text { Davis 1984 } & 36 & 929 & 6 & 308 & 1.6 \% \\ \text { Lichtenstein 2000 } & 15 & 349 & 13 & 302 & 2.1 \% \\ \text { Lichtenstein 2008 } & 38 & 900 & 50 & 919 & 4.9 \% \\ \text { Orleans 1991 } & 92 & 938 & 52 & 465 & 6.6 \% \\ \text { Parekh 2014 } & 52 & 201 & 53 & 196 & 6.5 \% \\ \text { Subtotal (95\% Cl) } & & \mathbf{4 3 4 7} & & \mathbf{2 6 7 6} & \mathbf{2 6 . 4} \% \\ \text { Total events } & 279 & & 208 & & \end{array}$

Heterogeneity: $\operatorname{Tau}^{2}=0.01 ; \mathrm{Chi}^{2}=6.36, \mathrm{df}=5(\mathrm{P}=0.27) ;\left.\right|^{2}=21 \%$

Test for overall effect: $Z=1.30(P=0.19)$

2.1.3 Face-to-face contact/No materials for control

$\begin{array}{lrrrrr}\text { Betson } 1998 & 5 & 181 & 8 & 241 & 1.0 \% \\ \text { Campbell } 1986 & 21 & 535 & 18 & 671 & 2.7 \% \\ \text { Prue } 1983 & 8 & 30 & 1 & 10 & 0.3 \% \\ \text { Subtotal (95\% Cl) } & & \mathbf{7 4 6} & & \mathbf{9 2 2} & \mathbf{4 . 0} \% \\ \text { Total events } & 34 & & 27 & & \end{array}$

Heterogeneity: $\mathrm{Tau}^{2}=0.00 ; \mathrm{Chi}^{2}=1.28, \mathrm{df}=2(\mathrm{P}=0.53) ; \mathrm{I}^{2}=0 \%$

Test for overall effect: $Z=1.12(P=0.26)$

\subsubsection{Face-to-face contact/Leaflet for control}

$\begin{array}{lcccccc}\text { Resnicow } 1997 & 73 & 650 & 40 & 504 & 5.7 \% & 1.42[0.98,2.04] \\ \text { Subtotal (95\% Cl) } & & \mathbf{6 5 0} & & \mathbf{5 0 4} & \mathbf{5 . 7 \%} & \mathbf{1 . 4 2}[\mathbf{0 . 9 8 , 2 . 0 4}] \\ \text { Total events } & 73 & & 40 & & & \end{array}$

Heterogeneity Not applicable

Test for overall effect: $Z=1.85$ ( $P=0.06)$

\subsubsection{Advice/No materials for control}

$\begin{array}{lrrrrr}\text { Betson } 1998 & 9 & 230 & 5 & 213 & 1.0 \% \\ \text { BTS 1983 } & 32 & 401 & 33 & 395 & 4.2 \% \\ \text { Davies } 1992 & 2 & 153 & 4 & 154 & 0.4 \% \\ \text { Janz } 1987 & 14 & 75 & 8 & 69 & 1.7 \% \\ \text { Kottke } 1989 & 32 & 593 & 36 & 660 & 4.2 \% \\ \text { Pederson } 1983 & 5 & 35 & 10 & 40 & 1.2 \% \\ \text { Rice } 1994 & 3 & 90 & 16 & 93 & 0.8 \% \\ \text { Thompson 1988 } & 26 & 188 & 26 & 192 & 3.7 \% \\ \text { Subtotal (95\% Cl) } & & \mathbf{1 7 6 5} & & \mathbf{1 8 1 6} & \mathbf{1 7 . 4 \%} \\ \text { Total events } & 123 & & 138 & & \end{array}$

Heterogeneity: $\mathrm{Tau}^{2}=0.08 ; \mathrm{Chi}^{2}=11.23, \mathrm{df}=7(\mathrm{P}=0.13) ; \mathrm{I}^{2}=38 \%$

Test for overall effect: $Z=0.54(P=0.59)$

2.1.6 Advice/Leaflet for control

Harackiewicz 1988
$1.30[0.90,1.86]$

$0.77[0.29,2.05]$

$0.68[0.26,1.75]$

$1.79[0.89,3.61]$

$1.17[0.88,1.56]$

$0.88[0.51,1.52]$

$1.43[0.51,3.99]$

$1.69[1.00,2.83]$

$1.67[0.70,3.96]$

$1.14[0.87,1.49]$

$0.99[0.58,1.69]$

$1.19[1.03,1.37]$

$0.64[0.42,0.98]$

$1.99[0.85,4.68]$

$1.00[0.48,2.06]$

$0.78[0.51,1.17]$

$0.88[0.64,1.21]$

$0.96[0.69,1.33]$

$0.87[0.71,1.07]$

$0.83[0.28,2.50]$

$1.46[0.79,2.72]$

$2.67[0.38,18.78]$

$1.35[0.80,2.26]$ 


\section{Figure 3. (Continued)}

2.1.6 Advice/Leaflet for control

$\begin{array}{lrrrrr}\text { Harackiewicz 1988 } & 7 & 52 & 3 & 46 & 0.7 \% \\ \text { Hollis } 1993 & 22 & 675 & 15 & 708 & 2.5 \% \\ \text { Lando } 1988 & 29 & 156 & 32 & 147 & 4.4 \% \\ \text { Subtotal }(95 \% \mathrm{Cl}) & & \mathbf{8 8 3} & & \mathbf{9 0 1} & \mathbf{7 . 7} \% \\ \text { Total events } & 58 & & 50 & & \end{array}$

Heterogeneity: $\operatorname{Tau}^{2}=0.08 ; \mathrm{Chi}^{2}=3.19, \mathrm{df}=2(\mathrm{P}=0.20) ; \mathrm{I}^{2}=37 \%$

Test for overall effect: $Z=0.65(P=0.52)$

Total $(95 \% \mathrm{Cl}) \quad \mathbf{1 5 1 1 4} \quad 13337 \quad \mathbf{1 0 0 . 0} \%$
Total events $\quad 983 \quad 794$
Heterogeneity: Tau $\mathrm{T}^{2}=0.02 ; \mathrm{Chi}^{2}=41.37, \mathrm{df}=31(\mathrm{P}=0.10) ; \mathrm{I}^{2}=25 \%$
Test for overall effect: $\mathrm{Z}=1.07(\mathrm{P}=0.28)$
Test for subqroup differences: $\mathrm{Chi}^{2}=9.73, \mathrm{df}=5(\mathrm{P}=0.08), \mathrm{I}^{2}=48.6 \%$

\section{Tailored self-help materials (Comparisons 3 and 4)}

Participants in 10 studies receiving tailored self-help materials had higher quit rates than those receiving no materials at all ( $\mathrm{n}=$ 14,359; RR 1.34, 95\% Cl 1.19 to $1.51 ; \mathrm{I}^{2}=0 \%$; Analysis 3.1.1). Control group quit rates were $4 \%$ to $7 \%$. Estimates were largely based on sustained but self-reported abstinence, with the exception of Prochaska 2005, which reported only point prevalence quit rates. In two studies comparing tailored materials with brief advice (n $=2992$ ), the risk ratio favoured the self-help intervention but confidence intervals were wide (RR $1.13,95 \% \mathrm{Cl} 0.86$ to $1.49 ; \mathrm{I}^{2}$ $=0 \%$; Analysis 3.1.2). In the two studies evaluating tailored selfhelp as an adjunct to brief advice, the risk ratio favoured the selfhelp intervention, and confidence intervals excluded no effect ( $\mathrm{n}=$ 1839; RR 1.72, 95\% Cl 1.17 to $2.53 ; \mathrm{I}^{2}=10 \%$; Analysis 3.1.3). When we pooled these three groups of studies comparing tailored selfhelp materials with no self-help, the overall result favoured selfhelp interventions with confidence intervals excluding no effect (n $=19,190 ;$ RR $1.34,95 \%$ Cl 1.20 to $\left.1.49 ;\left.\right|^{2}=0 \%\right)$.
$2.06[0.57,7.52]$

$1.54[0.80,2.94]$

$0.85[0.54,1.34]$

$1.18[0.71,1.95]$

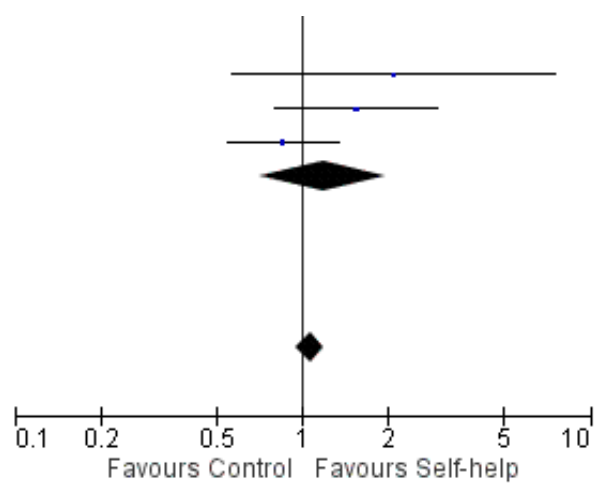

In other studies of tailored materials, the control groups received standard self-help materials. Ten studies that matched intervention and control groups for number of contacts did not detect a benefit ( $\mathrm{n}=11,024 ; \mathrm{RR} 1.07,95 \% \mathrm{Cl} 0.89$ to $1.30 ; \mathrm{I}^{2}=50 \%$; Analysis 4.1.1; Figure 4). We noted some evidence of heterogeneity $\left(I^{2}=50 \%\right)$, largely contributed by Becona 2001a where there was a significant effect of weekly feedback reports. Sutton 2007 included some recent quitters for whom the effect of intervention was smaller, but restricting inclusion to those still smoking at enrolment had little impact on the pooled estimate. Velicer 1999 showed an almost significant effect based on numbers randomised. Excluding dropouts from the denominators increased the estimated effect a little because more people were lost from the expert system intervention groups. This study also tested different numbers of tailored versus non-tailored mailings but did not detect a consistent dose-response effect (data not reported). 
Figure 4. Tailored self-help materials: Long-term abstinence.

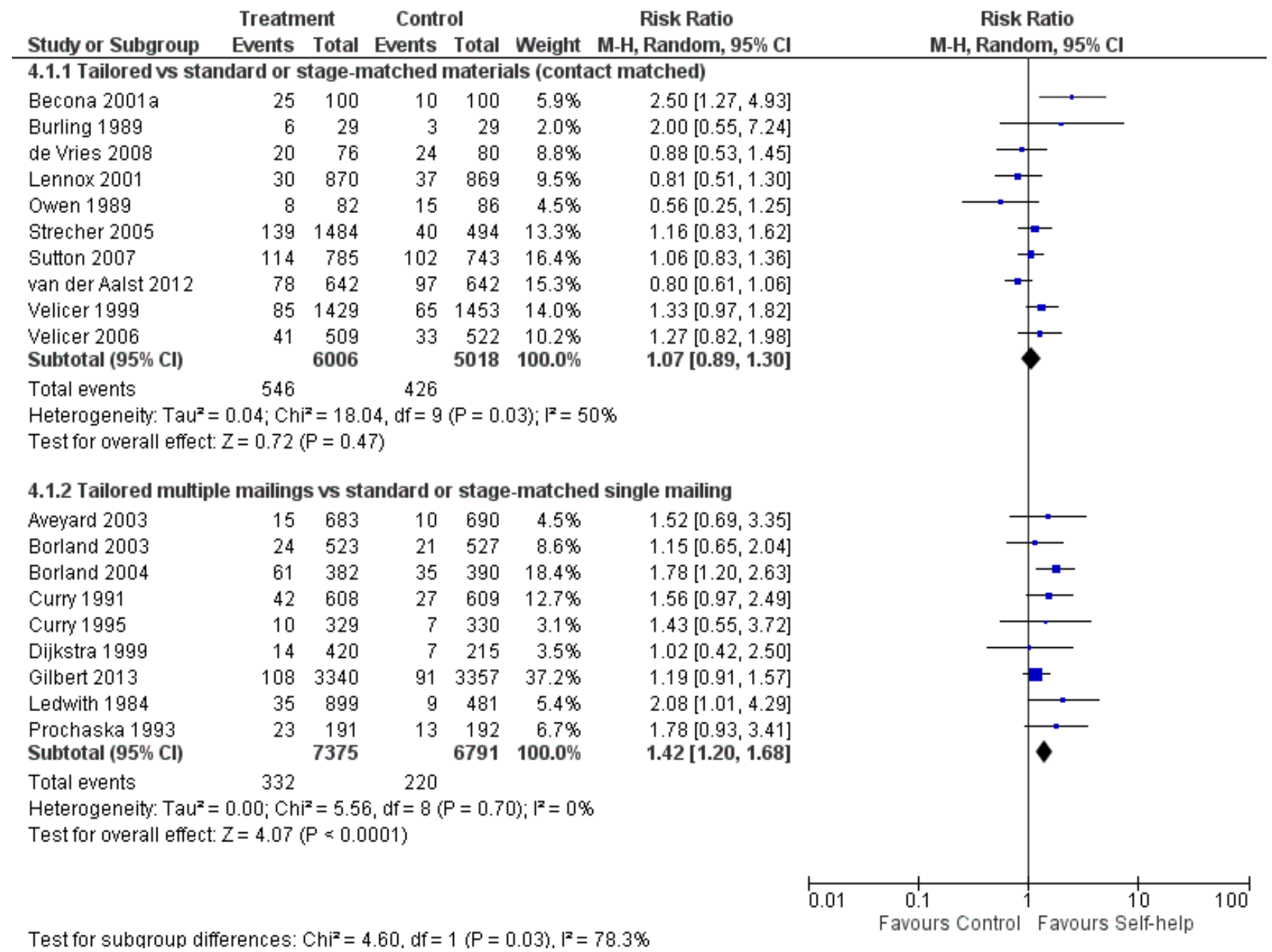

Nine studies that compared tailored materials with a non-tailored control and in which the tailored arms received multiple contacts and the non-tailored arms received a single contact found consistent results in favour of multiple tailored materials. Although none of these studies individually had statistically significant results, the pooled estimate suggests benefit of the intervention ( $\mathrm{n}$ $=14,166 ; \mathrm{RR} 1.42,95 \% \mathrm{Cl} 1.20$ to $1.68 ; \mathrm{I}^{2}=0 \%$; Analysis 4.1.2; Figure 4).

Webb 2013 detected a benefit of 'placebo tailoring' ( $n=424$; RR 1.98 , $95 \% \mathrm{Cl} 1.18$ to 3.31 ; analysis not shown), suggesting that the actual content of the tailored message may be less important than the perception that it is individualised.

\section{Self-help materials plus nicotine replacement therapy (NRT) compared to NRT alone (Comparison 5)}

Studies that specifically examined self-help materials in addition to NRT did not show any evidence of additional benefit from these materials over the relatively high quit rates achieved with use of NRT ( $n=1769$; RR 1.05, 95\% Cl 0.86 to $1.30 ; 1^{2}=0 \%$; Analysis 5.1). The control group quit rate was over $20 \%$ in two of the three studies. Results show no difference between the two studies using standard materials and the two using tailored materials. Due to insufficient data, we were unable to include another relevant study in this analysis (Fraser 2014); however, this study also did not detect a statistically significant benefit of standard self-help as an adjunct to NRT.

\section{Other enhancements or adjuncts to self-help materials (Comparison 6)}

\section{Additional written materials}

Pooled results from four studies of additional written materials favoured the intervention, but the lower confidence interval crossed the line of no effect and there was substantial heterogeneity (RR $1.20,95 \% \mathrm{Cl} 0.91$ to $1.58 ;\left.\right|^{2}=73 \%$; Analysis 6.1.1). We compared the two arms of Brandon 2016 with control separately in the meta-analysis. However, when compared with each other the results favoured the standard mailings arm over the intensive mailings arm (RR $1.22,95 \% \mathrm{Cl} 1.02$ to 1.47 ). Cuckle 1984 did not send further materials until six months after sending the initial 'quit kit', but excluding this study does not affect the estimate. We excluded one previously included study from this update because the intervention was given for relapse prevention (Killen 1990). Another Cochrane Review included this study (Hajek 2013).

\section{Additional video}

Killen 1997 used a video as an adjunct to written materials and did not detect a significant overall benefit $(n=424 ; \mathrm{RR} 0.73,95 \% \mathrm{Cl}$ 0.35 to $1.51 ; I^{2}=38 \%$; Analysis 6.1 .2 ). There was a non-significantly 
lower quit rate in the active nicotine patch group amongst those who received the video as well as written materials.

\section{Materials targeted at particular populations of smokers}

Five studies of materials targeted at specific populations failed to show evidence of significant benefit compared to standard materials ( $\mathrm{n}=3101$; RR 1.12, $95 \% \mathrm{Cl} 0.90$ to $1.38 ; \mathrm{I}^{2}=0 \%$; Analysis 6.1.3). Two studies provided telephone counselling to callers to quitlines before sending them materials (Davis 1992; Orleans 1998 (in which the counselling was also tailored)), and Nollen 2007 provided all participants with nicotine replacement therapy. These common components may have contributed to the success in quitting among all groups and limited the potential to detect effects of small differences in adjunct materials.

\section{Comparisons between different types of self-help material}

We did not perform meta-analysis of this heterogeneous group of studies. Glasgow $1981(n=88)$ compared two different manuals and found no evidence of a difference because of very wide confidence intervals (RR 3.00, 95\% Cl 0.13 to 67.51). Omenn 1988 ( $n=243$ ) compared a multiple-component manual with a quitters' guide and starter programme, finding no evidence of difference in quit rates (RR $1.30,95 \% \mathrm{Cl} 0.46$ to 3.71). ICRF $1994(\mathrm{n}=1686)$ also found no significant difference in outcome between those given a longer or a shorter booklet in conjunction with either a nicotine or placebo patch and nurse support (RR $1.02,95 \% \mathrm{Cl} 0.81,1.27$ ). Berman 1995 compared two types of materials for 348 smoking participants volunteering for heart health screening and cessation. There was no significant difference in quit rates (RR $0.72,95 \% \mathrm{Cl}$ 0.37 to 1.43$)$. Clark $2004(n=171)$ did not detect the hypothesised benefit of a list of internet resources over standard material. These results favoured the standard materials but with wide confidence intervals (RR 0.45, 95\% Cl 0.14 to 1.40). Becona 2001b ( $\mathrm{n}=482$ ) compared weekly mailings with a single manual and detected no significant difference (RR $0.88,95 \% \mathrm{Cl} 0.64$ to 1.19). Smith 2004 $(n=632)$ compared a 44-page booklet with a pamphlet when used as adjuncts for motivated quitters receiving an extended telephone counselling session and one of two intensities of followup counselling. The effect estimate favoured the longer booklet but the confidence intervals were wide, including the line of no effect (RR 3.26, 95\% Cl 0.98 to 10.85). Sykes $2001(n=260)$ showed a statistically significant effect after six months with a more than three-fold increase in the chance of quitting when comparing a cognitive-behavioural self-help programme with a standard leaflet, with both used as an adjunct to a single introductory session in a group format (RR $3.45,95 \% \mathrm{Cl} 1.44$ to 8.26 ). This finding was sustained at 12 months' follow-up (Marks 2002; RR 3.77, 95\% Cl 1.59 to 8.96$)$.

\section{DISCUSSION}

\section{Summary of main results}

We defined 'self-help materials' as those providing a structured approach to smoking cessation. Using this definition, we found moderate evidence that such materials, used on their own and compared with no intervention, marginally but significantly increased the number of people able to quit smoking (Summary of findings for the main comparison). The point estimate was higher for tailored materials than for non-tailored materials, but we found no significant differences between studies comparing tailored and non-tailored materials directly. For non-tailored materials, the certainty of the result was moderate because whilst the intervention was compared with a no-intervention control, the evidence came from studies conducted in high-income countries, where more intensive forms of support are readily available. For tailored materials, where the confidence intervals did exclude the possibility of no effect, certainty was moderate due to risk of bias in the included studies.

Providing non-tailored self-help materials in addition to advice from a healthcare professional did not improve the outcome. However, tailored self-help as an adjunct to brief advice did provide additional benefit, but this comparison included only two studies. We found little evidence of an effect of self-help materials given in addition to nicotine replacement therapy (NRT).

\section{Overall completeness and applicability of evidence}

Self-help programmes provide information on how to quit smoking but do not provide the sense of being supported nor the interactive elements of more sophisticated behavioural programmes. In many high-income countries, people know how to quit smoking or can find advice easily; therefore, in these contexts, it is possible that self-help interventions are less effective than might be the case where such information is not generally known or easily available. The studies included in this review overwhelmingly represent populations with this knowledge and with access to more intensive stop-smoking support (of the 75 included studies, 74 were conducted in high-income countries according to the World Bank definition; the one outlier was conducted in Hong Kong). This review, therefore, can inform decisions as to whether print-based self-help should be used in developed countries, but paradoxically it cannot tell us about the population that these interventions are now most likely to benefit - people who do not have other support available. By the 2020s or early 2030s, the World Health Organization estimates that more than 7 million tobacco-related deaths will occur in low- and middle-income countries each year. In light of this, even a very modest effect size could have significant public health impact when applied at a population level. Further research conducted outside of high-income countries is therefore needed to determine whether print-based self-help interventions still have a role to play. Without this, the evidence is incomplete and may not be applicable to the most relevant population.

There is also the potential for ambiguity in the inclusion criteria for this review, as studies do not always report in detail the nature of print-based interventions, and some interventions may be borderline between print-based self-help and printed materials that simply provide information. As such, we may have excluded some studies in which the print-based intervention did constitute a self-help intervention as defined in this review on the grounds that it is not clear from the report that the printed materials constituted a structured programme for people to follow to quit smoking. However, whilst there is a risk that we may not have included some eligible studies, we have no reason to suspect that this should result in systematic bias.

Although our searches included clinical trials registries and other sources of unpublished data, we cannot rule out the risk of publication bias. However, we prepared funnel plots for all comparisons with at least 10 studies, and none provided evidence of asymmetry. 


\section{Certainty of the evidence}

We judged the evidence for our main comparisons to be of moderate certainty in accordance with GRADE. We downgraded the evidence for standard self-help programmes for being indirectly relevant to populations in low- and middle-income countries because evidence for this comparison came from studies conducted solely in high-income countries and because of differences between higher- and lower-income countries in literacy rates, availability of support, and prevalence of stop-smoking messages, there is reason to believe the intervention might work differently. We downgraded the evidence for tailored self-help materials because of risk of bias. Many study reports did not provide sufficient detail for judgement of risk of bias for some domains. Of the 75 included studies, we judged 30 of them (40\%) to be at high risk of bias for one or more domains.

\section{Potential biases in the review process}

Our conclusions about the effects of self-help materials are based on an intention-to-treat analysis in which we included all randomised participants, whether or not they received the intended intervention. We also made the assumption that all participants who could not be reached for follow-up or who declined further participation were still smoking. It has been argued that in minimal contact population-based studies, participants may be unreachable for reasons unrelated to their smoking status, and that the assumption that they are all smokers leads to unnecessarily conservative quit rates (Hall 2001; Prochaska 2001a). Prochaska, Velicer, and colleagues distinguish between those lost to follow-up and those who withdraw from the study. We have used numbers randomised in our primary analysis, but we conducted a sensitivity analysis of the effect of using numbers followed up as the denominator. This of course increases the average quit rates in both intervention and control groups, but because dropout rates are typically quite similar across study arms, this has only a small impact on the estimate of relative effect. It has no effect on our conclusions about tailoring.

One reason that it may be difficult to show efficacy for standard self-help programmes is the level of 'contamination'. Materials encouraging smokers to quit and giving tips are already relatively widely disseminated, so that smokers in a control arm who are motivated to try to give up may well have access to the same kinds of materials that experimental arm smokers have been given. On the other hand, there may be more fundamental reasons why behavioural interventions are more effective when delivered by face-to-face contact. Killen has suggested, for example, that the self-regulatory skills required to withstand the urge to smoke may be better learnt, rehearsed, and retained under the direct supervision of a therapist than through the simple modelling offered by self-help materials (Killen 1997). Strecher has suggested that the length of generic self-help manuals and pamphlets may discourage effective use of these materials (Strecher 1994). Meade 1989 suggested that self-help materials may be too advanced for many readers, and that comprehension can be improved by adjustment of the reading grade level. Tailored materials may have the potential to address these issues.

\section{Agreements and disagreements with other studies or reviews}

This review found a small effect in favour of print-based self-help compared with no intervention (risk ratio (RR) $1.19,95 \%$ confidence interval $(\mathrm{Cl}) 1.03$ to $1.37 ; \mathrm{I}^{2}=0 \%$ ). This effect is less pronounced than that found in the Cochrane Review of mobile-based interventions (Taylor 2017; RR 1.67, 95\% Cl 1.46 to $1.90 ; I^{2}=59 \%$ ), and it is more pronounced than that found in the Cochrane Review of internetbased interventions (Whittaker 2016; RR 0.92, 95\% Cl 0.78 to 1.09; $\left.1^{2}=0 \%\right)$. However, the results of the internet-based interventions review were based on a comparison with an active control rather than no treatment.

Our review favoured tailored self-help over no materials (RR 1.34, $95 \% \mathrm{Cl} 1.19$ to $1.51 ; \mathrm{I}^{2}=0 \%$ ). When comparing tailored self-help to non-tailored self-help, results favoured tailored interventions when the tailored interventions contained more mailings than the non-tailored interventions (RR $1.42,95 \% \mathrm{Cl} 1.20$ to $1.68 ; \mathrm{I}^{2}=0 \%$ ), but not when the two conditions were contact matched (RR 1.07, $95 \% \mathrm{Cl} 0.89$ to $\left.1.30 ; \mathrm{I}^{2}=50 \%\right)$. The Cochrane Review of internetbased interventions favoured interactive and tailored interventions over non-active control (RR $1.15,95 \% \mathrm{Cl} 1.01$ to 1.30 ) and favoured an interactive or tailored programme over a non-tailored internet intervention, but the estimate crossed the null (RR 1.10, 95\% $\mathrm{Cl} 0.99$ to $\left.1.22 ; \mathrm{I}^{2}=0 \%\right)$. The review did not comment on any differences in contact between groups, but it is unlikely that contact differed because of the online nature of the interventions. Given the difficulty of obtaining baseline data and the delays involved in mailing printed materials, newer formats for providing selfhelp support may have greater potential for providing relevant and timely interventions. Although the evidence from studies is not yet optimal, using the internet to provide individually tailored information and support appears promising and may avoid the limitations of printed self-help materials. Using mobile phones to deliver text message-based interventions also shows promise for supporting people who are making quit attempts.

\section{AUTHORS' CONCLUSIONS}

\section{Implications for practice}

Structured self-help programmes provided in short booklets increase the likelihood of a person stopping smoking successfully in the medium to long term. However, there is no evidence that they add to the effectiveness of brief advice or pharmacological interventions.

Print-based self-help that is tailored to the characteristics of individual smokers may be more helpful. However, more modern formats for providing tailored self-help support, such as the internet and mobile phones, may have greater potential because of advantages in gathering information to tailor by and in delivering support more quickly and flexibly.

\section{Implications for research}

Almost all included studies were conducted in high-income countries with well-developed tobacco control policies and high literacy rates. The effect of this climate on the intervention effectiveness is unclear. In low- and middle-income countries, tobacco control policies are often less developed and literacy rates may be lower than in high-income countries. Future research in low- and middle- income countries would be useful because the 
intervention is potentially more cost-effective than other cessation aids, but the impact of print-based self-help interventions in such a context remains unclear.

\section{A CKN OWLEDGEMENTS}

Our thanks to Sue Curry, Paul McDonald, and Saul Shiffman for their comments, and to Ann Varady, Joe Rossi, Christine Edwards, Neal Boyd, Virginia Rice, and Tracy Orleans for providing additional data from published or unpublished studies. Our thanks also to Timothy Lancaster and Lindsay Stead, who were the authors of previous versions of this review, and Sandra Wilcox and Lee Bromhead, who reviewed the plain language summary.

This project was supported by the National Institute for Health Research (NIHR), via Cochrane Infrastructure and Cochrane Programme Grant funding to the Cochrane Tobacco Addiction Group. The views and opinions expressed therein are those of the authors and do not necessarily reflect those of the Systematic Reviews Programme, NIHR, NHS, or the Department of Health and Social Care. JHB is also funded in part by the NIHR Oxford Biomedical Research Centre (BRC). 
R E F E R E N C E S

\section{References to studies included in this review}

\section{Aveyard 2003 \{published data only\}}

Aveyard P, Griffin C, Lawrence T, Cheng KK. A controlled trial of an expert system and self-help manual intervention based on the stages of change versus standard self-help materials in smoking cessation. Addiction 2003;98(3):345-54.

\section{Becona 2001a \{published data only\}}

Becona E, Vazquez FL. Effectiveness of personalized written feedback through a mail intervention for smoking cessation: a randomized-controlled trial in Spanish smokers. Journal of Consulting and Clinical Psychology 2001;69(1):33-40.

\section{Becona 2001b \{published data only\}}

Becona E, Vasquez FL. Comparison of the efficacy of a selfhelp smoking cessation by mail with a manual in one-time intervention or weekly intervention. Psiquis 2001;22:41-50.

\section{Berman 1995 \{published data only\}}

Berman BA, Gritz ER, Braxton Owens H, Nisenbaum R. Targeting adult smokers through a multi-ethnic public school system. Journal of Cancer Education 1995;10:91-101.

\section{Betson 1998 \{published and unpublished data\}}

Betson CL, Lam TH, Chung TWH, Chung SF. A randomized controlled trial of smoking cessation in Government out-patient clinics in Hong Kong (Abstract OS 321). Proceedings of the 10th World Conference on Tobacco or Health; Aug 24-28; Beijing, China. 1997:113.

\section{Borland 2003 \{published data only\}}

Borland R, Balmford J, Segan C, Livingston P, Owen N. The effectiveness of personalized smoking cessation strategies for callers to a Quitline service. Addiction 2003;98(6):837-46.

\section{Borland 2004 \{published data only\}}

Borland R, Balmford J, Hunt D. The effectiveness of personally tailored computer-generated advice letters for smoking cessation. Addiction 2004;99(3):369-77.

Brandon 2016 \{published data only (unpublished sought but not used)\}

* Brandon TH, Simmons VN, Sutton SK, Unrod M, Harrell PT, Meade CD, et al. Extended self-help for smoking cessation: a randomized controlled trial. American Journal of Preventive Medicine 2016;51(1):54-62.

Unrod M, Simmons VN, Sutton SK, Meltzer LR, Harrell PT, Meade $C D$, et al. A randomized clinical trial of self-help intervention for smoking cessation: research design, interventions, and baseline data. Contemporary Clinical Trials 2014;38(2):284-90.

\section{BTS 1983 \{published data only\}}

British Thoracic Society. Comparison of four methods of smoking withdrawal in patients with smoking related diseases. Report by a subcommittee of the Research Committee of the British Thoracic Society. BMJ 1983;286:595-7.
Burling 1989 \{published data only\}

Burling TA, Marotta J, Gonzalez R, Moltzen JO, Eng AM, Schmidt GA, et al. Computerized smoking cessation program for the worksite: treatment outcome and feasibility. Journal of Consulting and Clinical Psychology 1989;57:619-22.

\section{Campbell 1986 \{published data only\}}

Campbell IA, Hansford M, Prescott RJ. Effect of a "stop smoking" booklet on smokers attending for chest radiography: a controlled study. Thorax 1986;41:369-71.

Clark 2004 \{published data only\}

Clark MM, Cox LS, Jett JR, Patten CA, Schroeder DR, Nirelli LM, et al. Effectiveness of smoking cessation self-help materials in a lung cancer screening population. Lung Cancer 2004;44(1):13-21.

Cuckle 1984 \{published data only\}

Cuckle HS, van Vunakis H. The effectiveness of a postal smoking cessation 'kit'. Community Medicine 1984;6:210-5.

\section{Cummings 1988 \{published data only\}}

Cummings KM, Emont SL, Jaen C, Sciandra R. Format and quitting instructions as factors influencing the impact of a selfadministered quit smoking program. Health Education Quarterly 1988;15:199-216.

\section{Curry 1991 \{published data only\}}

Curry SJ, Wagner EH, Grothaus LC. Evaluation of intrinsic and extrinsic motivation interventions with a self-help smoking cessation program. Journal of Consulting and Clinical Psychology 1991;59:318-24.

\section{Curry 1995 \{published data only\}}

Curry SJ, McBride C, Grothaus LC, Louie D, Wagner EH. A randomized trial of self-help materials, personalized feedback, and telephone counselling with nonvolunteer smokers. Journal of Consulting and Clinical Psychology 1995;63:1005-114.

Davies 1992 \{published data only\}

Davies BL, Matte Lewis L, O'Connor AM, Dulberg CS, Drake ER. Evaluation of the "Time to Quit" self-help smoking cessation program. Canadian Journal of Public Health 1992;83:19-23.

Davis 1984 \{published data only\}

Davis AL, Faust R, Ordentlich M. Self-help smoking cessation and maintenance programs: a comparative study with 12 month follow-up by the American Lung Association. American Journal of Public Health 1984;74:1212-7.

\section{Davis 1992 \{published data only\}}

Davis SW, Cummings KM, Rimer BK, Sciandra R. The impact of tailored self-help smoking cessation guides on young mothers. Health Education Quarterly 1992;19:495-504.

de Vries 2008 \{published and unpublished data\}

Smeets T, Kremers SP, Brug J, de Vries H. Effects of tailored feedback on multiple health behaviors. [erratum appears in 
Ann Behav Med. 2007 Jul-Aug;34(1):104]. Annals of Behavioral Medicine 2007;33(2):117-23.

* de Vries H, Kremers SP, Smeets T, Brug J, Eijmael K. The effectiveness of tailored feedback and action plans in an intervention addressing multiple health behaviors. American Journal of Health Promotion 2008;22(6):417-25.

\section{Dijkstra 1998a \{published data only\}}

* Dijkstra A, Devries H, Roijackers J. Long-term effectiveness of computer-generated tailored feedback in smoking cessation. Health Education Research 1998;13:207-14.

Dijkstra A, Devries H, Roijackers J, vanBreukelen G. Individualized interventions in smoking cessation: a field experimental trial. Gedrag and Gezondheid Tijdschrift voor Psychologie and Gezondheid 1996;24:314-22.

Dijkstra A, de Vries H, Roijackers J, Van Breukelen G. Tailored interventions to communicate stage-matched information to smokers in different motivational stages. Journal of Consulting and Clinical Psychology 1998;66(3):549-57.

\section{Dijkstra 1999 \{published data only\}}

Dijkstra A, Devries H, Roijackers J. Targeting smokers with low readiness to change with tailored and nontailored self-help materials. Preventive Medicine 1999;28:203-11.

\section{Etter 2004 \{published data only\}}

Etter JF, Perneger TV. Effectiveness of a computer-tailored smoking cessation program. 11th World Conference on Tobacco or Health 6-11 August Chicago Abstract book. Chicago, Illinois, USA, 2000; Vol. 1:159.

Etter JF, Perneger TV. Effectiveness of a computer-tailored smoking cessation program: a randomized trial. Archives of Internal Medicine 2001;161(21):2596-601.

* Etter JF, Perneger TV. Post-intervention effect of a computer tailored smoking cessation programme. Journal of Epidemiology \& Community Health 2004;58:849-51.

Fraser 2014 \{published data only (unpublished sought but not used)\}

Fraser D, Kobinsky K, Smith SS, Kramer J, Theobald WE, Baker TB. Five population-based interventions for smoking cessation: a MOST trial. Translational Behavioral Medicine 2014;4:382-90.

\section{Gilbert 2013 \{published data only\}}

Bennett K, Gilbert H, Sutton S. Computer-tailored smoking cessation advice matched to reading ability: perceptions of participants from the ESCAPE trial. Patient Education and Counseling 2015;98:1577-84.

Bennett K, Gilbert H, Sutton S. Computer-tailored smoking cessation advice matched to reading ability: perceptions of participants from the ESCAPE trial. Patient Education and Counseling 2015;98:1577-84.

Gilbert H, Leurent B, Sutton S, Morris R, Alexis-Garsee C, Nazareth I. Factors predicting recruitment to a UK wide primary care smoking cessation study (the ESCAPE trial). Family Practice
2012;29(1):110-7. [CENTRAL: 814656; CRS: 9400123000012702 ; EMBASE: 2012054404; PUBMED: 21624941]

Gilbert H, Nazareth I, Sutton S, Morris R, Godfrey C. Effectiveness of computer-tailored Smoking Cessation Advice in Primary Care (ESCAPE): a randomised trial. Trials 2008;9:23. [CENTRAL: 707723; CRS: 9400123000005322 ; EMBASE: 2008278924]

* Gilbert HM, Leurent B, Sutton S, Alexis-Garsee C, Morris RW, Nazareth I. ESCAPE: a randomised controlled trial of computertailored smoking cessation advice in primary care. Addiction (Abingdon, England) 2013;108(4):811-9. [CENTRAL: 920999; CRS: 9400107000000699; PEER: Reviewed Journal: 2013-09671-028; PUBMED: 23072513]

Gilbert HM, Sutton SR, Leurent B, Alexis-Garsee C, Morris RW, Nazareth I. Characteristics of a population-wide sample of smokers recruited proactively for the ESCAPE trial. Public Health 2012;126(4):308-16. [CRS: 9400123000012586 ; EMBASE: 2012173870; PUBMED: 22385924]

Wu Q, Parrott S, Godfrey C, Gilbert H, Nazareth I, Leurent B, et al. Cost-effectiveness of computer-tailored smoking cessation advice in primary care: a randomized trial (ESCAPE). Nicotine \& Tobacco Research 2014;16:270-8.

\section{Glasgow 1981 \{published data only\}}

Glasgow RE, Schafer L, O'Neill HK. Self-help books and amount of therapist contact in smoking cessation programs. Journal of Consulting and Clinical Psychology 1981;49:659-67.

\section{Gritz 1992 \{published data only\}}

* Gritz ER, Berman BA, Bastani R, Wu M. A randomized trial of a self-help smoking cessation intervention in a nonvolunteer female population: testing the limits of the public health model. Health Psychology 1992;11:280-9.

Hudmon KS, Gritz ER, Clayton S, Nisenbaum R. Eating orientation, postcessation weight gain, and continued abstinence among female smokers receiving an unsolicited smoking cessation intervention. Health Psychology 1999;18:29-36.

\section{Harackiewicz 1988 \{published data only\}}

* Harackiewicz JM, Blair LW, Sansone C, Epstein JA, Stuchell RN. Nicotine gum and self-help manuals in smoking cessation: an evaluation in a medical context. Addictive Behaviors 1988;13:319-30.

Harackiewicz JM, Sansone C, Blair LW, Epstein JA, Manderlink G. Attributional processes in behavior change and maintenance: smoking cessation and continued abstinence. Journal of Consulting and Clinical Psychology 1987;55:372-8.

Hollis 1993 \{published data only\}

Hollis JF, Lichtenstein E, Vogt TM, Stevens VJ, Biglan A. Nurseassisted counseling for smokers in primary care. Annals of Internal Medicine 1993;118:521-5.

Hoving 2010 \{published data only\}

Hoving C, Mudde AN, Dijk F, De Vries H. Effectiveness of a smoking cessation intervention in Dutch pharmacies and 
general practices. Health Education 2010;110(1):17-29.

[CENTRAL: 782925; CRS: 9400123000005944$]$

Humerfelt 1998 \{published data only\}

* Humerfelt S, Eide GE, Kvale G, Aaro LE, Gulsvik A.

Effectiveness of postal smoking cessation advice: a randomized controlled trial in young men with reduced FEV1 and asbestos exposure. European Respiratory Journal 1998;11:284-90.

Humerfelt S, Eide GE, Kvale G, Aaro LE, Gulsvik A. Predictors of stopping smoking in a community of young adults [abstract]. European Respiratory Journal 1995;8 Suppl 19:11S.

Humerfelt S, Eide GE, Kvale G, Aaro LE, Gulsvik A. Smoking cessation after a doctor's postal advice to quit smoking among high risk male smokers in a community [abstract]. European Respiratory Journal 1995;8 Suppl 19:112S.

Humerfelt S, Kvale G, Aaro LE, Gulsvik A. Success rates of smoking cessation after a doctor's postal advice to quit smoking in a randomized trial among men with asbestos exposure and reduced FEV1 from a population survey [abstract]. European Respiratory Journal 1994;7 Suppl 18:255s.

\section{ICRF 1994 \{published data only\}}

* Imperial Cancer Research Fund General Practice Research Group. Effectiveness of a nicotine patch in helping people stop smoking: results of a randomised trial in general practice. $B M J$ 1993;306:1304-8.

Imperial Cancer Research Fund General Practice Research Group. Randomised trial of nicotine patches in general practice: results at one year. BMJ 1994;308:1476-7.

\section{Janz 1987 \{published data only\}}

Janz NK, Becker MH, Kirscht JP, Eraker SA, Billi JE, Woolliscroft JO. Evaluation of a minimal-contact smoking cessation intervention in an outpatient setting. American Journal of Public Health 1987;77:805-9.

\section{Killen 1997 \{published data only\}}

Killen JD, Fortmann SP, Davis L, Varady A. Nicotine patch and self-help video for cigarette smoking cessation. Journal of Consulting and Clinical Psychology 1997;65:663-72.

\section{Killen 1997 +NP \{published data only\}}

* Killen JD, Fortmann SP, Davis L, Varady A. Nicotine patch and self-help video for cigarette smoking cessation. Journal of Consulting and Clinical Psychology 1997;65:663-72.

Kottke 1989 \{published data only\}

Kottke TE, Brekke ML, Solberg LI, Hughes JR. A randomized trial to increase smoking intervention by physicians. Doctors Helping Smokers, Round I. JAMA 1989;261:2101-6.

\section{Lando 1988 \{published data only\}}

Lando HA, Kalb EA, McGovern PG. Behavioral self-help materials as an adjunct to nicotine gum. Addictive Behaviors 1988;13:181-4.

\section{Lando 1991 \{published data only\}}

Lando HA, Pirie PL, McGovern PG, Pechacek TF, Swim J, Loken B. A comparison of self-help approaches to smoking cessation. Addictive Behaviors 1991;16:183-93.

\section{Ledwith 1984 \{published data only\}}

* Ledwith F. Immediate and delayed effects of postal advice on stopping smoking. Health Bulletin 1984;42:332-44.

Ledwith F. Immediate and delayed effects of postal advice on stopping smoking. Proceedings of the 5th World Conference on Smoking and Health, July 10-15 1983, Winnipeg. Ottawa: Canadian Council on Smoking and Health, 1984; Vol. 1:383-7.

\section{Lennox 2001 \{published data only\}}

* Lennox AS, Osman LM, Reiter E, Robertson R, Friend J, McCann I, et al. Cost effectiveness of computer tailored and non-tailored smoking cessation letters in general practice: randomised controlled trial. BMJ 2001;322(7299):1396.

Reiter E, Robertson R, Osman LM. Lessons from a failure: generating tailored smoking cessation letters. Artificial Intelligence 2003;144:41-58.

\section{Lichtenstein 2000 \{published data only\}}

Lee ME, Lichtenstein E, Andrews JA, Glasgow RE, Hampson SE. Radon-smoking synergy: a population-based behavioral risk reduction approach. Preventive Medicine 1999;29:222-7.

* Lichtenstein E, Andrews JA, Lee ME, Glasgow RE, Hampson SE. Using radon risk to motivate smoking reduction: evaluation of written materials and brief telephone counselling. Tobacco Control 2000;9:320-6.

\section{Lichtenstein 2008 \{published data only\}}

Hampson SE, Andrews JA, Barckley M, Lichtenstein E, Lee ME. Personality traits, perceived risk, and risk-reduction behaviors: a further study of smoking and radon. Health Psychology 2006;25(4):530-6.

* Lichtenstein E, Boles SM, Lee ME, Hampson SE, Glasgow RE, Fellows J. Using radon risk to motivate smoking reduction II: randomized evaluation of brief telephone counseling and a targeted video. Health Education Research 2008;23(2):191-201.

Lichtenstein E, Lee ME, Boles SM, Foster L, Hampson SE. Using radon risk to motivate smoking reduction: replication and extension (PO3 21). Society for Research on Nicotine and Tobacco 8th Annual Meeting February 20-23 Savannah, Georgia. 2002.

Lipkus 1999 \{published data only\}

Lipkus IM, Lyna PR, Rimer BK. Using tailored interventions to enhance smoking cessation among African-Americans at a community health center. Nicotine \& Tobacco Research 1999;1(1):77-85.

\section{McFall 1993 \{published data only\}}

McFall SL, Michener A, Rubin D, Flay BR, Mermelstein RJ, Burton $D$, et al. The effects and use of maintenance newsletters in a smoking cessation intervention. Addictive Behaviors 1993;18:151-8. 


\section{Meyer 2008 \{published data only\}}

Haug S, Meyer C, Ulbricht S, Gross B, Rumpf HJ, John U. Need for cognition as a predictor and a moderator of outcome in a tailored letters smoking cessation intervention. Health Psychology 2010;29(4):367-73. [CENTRAL: 761578; CRS: 9400123000005761; PUBMED: 20658823]

Haug S, Meyer C, Ulbricht S, Schorr G, Ruge J, Rumpf HJ, et al. Predictors and moderators of outcome in different brief interventions for smoking cessation in general medical practice. Patient Education and Counselling 2010;78(1):57-64.

Klein G, Ulbricht S, Haug S, Gross B, Rumpf HJ, John U, et al. Effects of practitioner-delivered brief counseling and computergenerated tailored letters on cigarettes per day among smokers who do not quit - a randomized controlled trial. Drug and Alcohol Dependence 2010;112(1-2):81-9.

* Meyer C, Ulbricht S, Baumeister SE, Schumann A, Ruge J, Bisch of $\mathrm{G}$, et al. Proactive interventions for smoking cessation in general medical practice: a quasi-randomized controlled trial to examine the efficacy of computer-tailored letters and physiciandelivered brief advice. Addiction 2008;103(2):294-304.

Schumann A, John U, Ulbricht S, Ruge J, Bischof G, Meyer C. Computer-generated tailored feedback letters for smoking cessation: theoretical and empirical variability of tailoring. International Journal of Medical Informatics 2008;77(11):715-22.

Schumann A, John U, Ulbricht S, Ruge J, Bischof G, Meyer C. Variability of tailoring of a smoking cessation intervention based on the transtheoretical model. Addictive Behaviors 2007;32(12):3083-7.

Ulrich JU, Ulbricht S, Goeze C, Meyer C. Brief intervention to motivate smokers to quit in primary medical care. European Journal of Cardiovascular Prevention and Rehabilitation 2011;18(1 Suppl 1):S40. [CENTRAL: 835566; CRS: 9400123000011714]

\section{Meyer 2012 \{published data only\}}

* Meyer C, Ulbricht S, Gross B, Kastel L, Wittrien S, Klein G, et al. Adoption, reach and effectiveness of computer-based, practitioner delivered and combined smoking interventions in general medical practices: a three-arm cluster randomized trial. Drug and Alcohol Dependence 2012;121(1-2):124-32. [CENTRAL: 814655; CRS: 9400123000012692 ; EMBASE: 2012037444; PUBMED: 21924563]

Ulrich JU, Ulbricht S, Goeze C, Meyer C. Brief intervention to motivate smokers to quit in primary medical care. European Journal of Cardiovascular Prevention and Rehabilitation 2011;18(1 Suppl 1):S40. [CENTRAL: 835566; CRS: 9400123000011714]

\section{Meyer 2016 \{published data only\}}

Meyer C, Ulbricht S, Haug S, Broda A, Bischof G, Rumpf H-J, et al. Motivating smokers to quit using computer-generated letters that target either reduction or cessation: a population-based randomized controlled trial among smokers who do not intend to quit. Drug and Alcohol Dependence 2016;166:177-86.

\section{Nollen 2007 \{published data only\}}

Ahluwalia JS, Kimber R, Mayo MS, Ahluwalia HK, Choi WS, Schmelsle KH, et al. African American smokers interested and eligible for a smoking cessation clinical trial: predictors of not returning for randomization. Annals of Epidemiology 2002;12:206-12.

Ahluwalia JS, Richter KP, Mayo MS, Resnicow K. Quit for Life: a randomized trial of culturally sensitive materials for smoking cessation in African Americans. Journal of General Internal Medicine 1999;14 Suppl 2:6.

Catley D, Ahluwalia JS, Resnicow K, Nazir N. Depressive symptoms and smoking cessation among inner-city African Americans using the nicotine patch. Nicotine \& Tobacco Research 2003;5(1):61-8.

* Nollen N, Ahluwalia JS, Mayo MS, Richter K, Choi WS, Okuyemi KS, et al. A randomized trial of targeted educational materials for smoking cessation in African Americans using transdermal nicotine. Health Education \& Behavior 2007;34(6):911-27.

\section{Omenn 1988 \{published data only\}}

* Omenn GS, Thompson B, Sexton M, Hessol N, Breitenstein B, Curry $S$, et al. A randomized comparison of worksite-sponsored smoking cessation programs. American Journal of Preventive Medicine 1988;4:261-7.

Thompson B, Omenn G, Sexton M, Breitenstein B, Hessol N, Curry S, et al. Worksite smoking cessation: a test of two programs. Progress in Clinical and Biological Research 1987;248:93-100.

\section{Orleans 1991 \{published data only\}}

* Orleans CT, Schoenbach VJ, Wagner EH, Quade D, Salmon MA, Pearson DC, et al. Self-help quit smoking interventions: effects of self-help materials, social support instructions, and telephone counseling. Journal of Consulting and Clinical Psychology 1991;59:439-48.

Schoenbach VJ, Orleans CT, Wagner EH, Quade D, Salmon MAP, Porter CQ. Characteristics of smokers who enroll and quit in self-help programs. Health Education Research 1992;7:369-80.

\section{Orleans 1998 \{published data only\}}

Orleans CT, Boyd NR, Bingler R, Sutton C, Fairclough D, Heller D, et al. A self-help intervention for African American smokers: tailoring Cancer Information Service counseling for a special population. Preventive Medicine 1998;27:S61-S70.

\section{Orleans 2000 \{published and unpublished data\}}

Orleans CT, Boyd NR, Noll E, Crosette L, Glassman B. Computer tailored intervention for older smokers using transdermal nicotine. Tobacco Control 2000;9 Suppl 1:153.

\section{Owen 1989 \{published data only\}}

Owen N, Ewins AL, Lee C. Smoking cessation by mail: a comparison of standard and personalized correspondence course formats. Addictive Behaviors 1989;14:355-63. 
Pallonen 1994 \{published data only\}

Pallonen UE, Leskinen L, Prochaska JO, Willey CJ, Kaariainen R, Salonen JT. A 2-year self-help smoking cessation manual intervention among middle-aged Finnish men: an application of the transtheoretical model. Preventive Medicine 1994;23:507-14.

Parekh 2014 \{published data only\}

Parekh S, King D, Boyle FM, Vandelanotte C. Randomized controlled trial of a computer-tailored multiple health behaviour intervention in general practice: 12-month followup results. International Journal of Behavioral Nutrition and Physical Activity 2014;11(1):41.

Parekh S, Vandelanotte C, King D, Boyle FM. Improving diet, physical activity and other lifestyle behaviours using computertailored advice in general practice: a randomised controlled trial. International Journal of Behavioral Nutrition and Physical Activity 2012;9:58. [CRS: 9400123000016867]

\section{Pederson 1983 \{published data only\}}

Pederson LL, Wood T, Lefcoe NM. Use of a self-help smoking cessation manual as an adjunct to advice from a respiratory specialist. International Journal of the Addictions 1983;18:777-82.

\section{Prochaska 1993 \{published and unpublished data\}}

Norman SB, Norman GJ, Rossi JS, Prochaska JO. Identifying high- and low-success smoking cessation subgroups using signal detection analysis. Addictive Behaviors 2006;31:31-41.

* Prochaska JO, Di Clemente CC, Velicer WF, Rossi JS. Standardized, individualized, interactive, and personalized self-help programs for smoking cessation. Health Psychology 1993;12:399-405.

\section{Prochaska 2001a \{published data only\}}

* Prochaska JO, Velicer WF, Fava JL, Ruggiero L, Laforge RG, Rossi JS, et al. Counselor and stimulus control enhancements of a stage-matched expert system intervention for smokers in a managed care setting. Preventive Medicine 2001;32:23-32.

Sun X, Prochaska JO, Velicer WF, Laforge RG. Transtheoretical principles and processes for quitting smoking: a 24-month comparison of a representative sample of quitters, relapsers, and non-quitters. Addictive Behaviors 2007;32(12):2707-26.

Velicer WF, Redding CA, Sun X, Prochaska JO. Demographic variables, smoking variables, and outcome across five studies. Health Psychology 2007;26(3):278-87.

\section{Prochaska 2001b \{published data only\}}

* Prochaska JO, Velicer WF, Fava JL, Rossi JS, Tsoh JY. Evaluating a population-based recruitment approach and a stage-based expert system intervention for smoking cessation. Addictive Behaviors 2001;26:583-602.

Velicer WF, Redding CA, Sun X, Prochaska JO. Demographic variables, smoking variables, and outcome across five studies. Health Psychology 2007;26(3):278-87.

\section{Prochaska 2004 \{published data only\}}

Prochaska JO, Velicer WF, Rossi JS, Redding CA, Greene GW, Rossi SR, et al. Multiple risk expert systems interventions: impact of simultaneous stage-matched expert system interventions for smoking, high-fat diet, and sun exposure in a population of parents. Health Psychology 2004;23:503-16.

Prochaska 2005 \{published data only\}

Prochaska JO, Velicer WF, Redding C, Rossi JS, Goldstein M, DePue J, et al. Stage-based expert systems to guide a population of primary care patients to quit smoking, eat healthier, prevent skin cancer, and receive regular mammograms. Preventive Medicine 2005;41:406-16.

Prue 1983 \{published data only\}

Prue DM, Davis CJ, Martin JE, Moss RA. An investigation of a minimal contact brand fading program for smoking treatment. Addictive Behaviors 1983;8:307-10.

\section{Resnicow 1997 \{published data only\}}

Resnicow K, Royce J, Vaughan R, Orlandi MA, Smith M. Analysis of a multicomponent smoking cessation project: what worked and why. Preventive Medicine 1997;26:373-81.

* Resnicow K, Vaughan R, Futterman R, Weston RE, Royce J, Parms $C$, et al. A self-help smoking cessation program for inner-city African Americans: results from the Harlem health connection project. Health Education \& Behavior 1997;24:201-17.

\section{Rice 1994 \{published and unpublished data}

Rice VH, Fox DH, Lepczyk M, Sieggreen M, Mullin M, Jarosz P, et al. A comparison of nursing interventions for smoking cessation in adults with cardiovascular health problems. Heart \& Lung 1994;23:473-86.

\section{Schofield 1999 \{published data only\}}

Schofield PE, Hill DJ, Johnston CI, Streeton JA. The effectiveness of a directly mailed smoking cessation intervention to Australian discharged hospital patients. Preventive Medicine 1999;29(6 Pt 1):527-34.

\section{Schumann 2008 \{published data only\}}

* Schumann A, John U, Baumeister SE, Ulbricht S, Rumpf HJ, Meyer C. Computer-tailored smoking cessation intervention in a general population setting in Germany: outcome of a randomized controlled trial. Nicotine \& Tobacco Research 2008;10:371-9.

Schumann A, John U, Rumpf HJ, Hapke U, Meyer C. Changes in the 'stages of change' as outcome measures of a smoking cessation intervention: a randomized controlled trial. Preventive Medicine 2006;43(2):101-6.

Schumann A, John U, Ulbricht S, Ruge J, Bischof G, Meyer C. Computer-generated tailored feedback letters for smoking cessation: theoretical and empirical variability of tailoring. International Journal of Medical Informatics 2008;77(11):715-22.

Schumann A, John U, Ulbricht S, Ruge J, Bischof G, Meyer C. Variability of tailoring of a smoking cessation intervention 
based on the transtheoretical model. Addictive Behaviors 2007;32(12):3083-7.

\section{Smith 2004 \{published data only\}}

Smith PM, Cameron R, McDonald PW, Kawash B, Madill C, Brown KS. Telephone counseling for population-based smoking cessation. American Journal of Health Behavior 2004;28(3):231-41.

\section{Strecher 2005 \{published data only\}}

Strecher VJ, Marcus A, Bishop K, Fleisher L, Stengle W, Levinson $A$, et al. A randomized controlled trial of multiple tailored messages for smoking cessation among callers to the cancer information service. Journal of Health Communication 2005;10 Suppl 1:105-18.

\section{Sutton 2007 \{published data only\}}

Gilbert H, Sutton S. Does adding tailored feedback to telephone counselling improve quit rates? (POS1-033). Society for Research on Nicotine and Tobacco 10th Annual Meeting February 18-21, Phoenix, Arizona. 2004:43.

* Sutton S, Gilbert H. Effectiveness of individually tailored smoking cessation advice letters as an adjunct to telephone counselling and generic self-help materials: randomized controlled trial. Addiction 2007;102(6):994-1000.

\section{Sykes 2001 \{published data only\}}

Marks DF, Sykes CM. Randomized controlled trial of cognitive behavioural therapy for smokers living in a deprived area of London: outcome at one-year follow-up. Psychology, Health and Medicine 2002;7:17-24.

* Sykes CM, Marks DF. Effectiveness of a cognitive behaviour therapy self-help programme for smokers in London, UK. Health Promotion International 2001;16:255-60.

\section{Thompson 1988 \{published data only\}}

Thompson RS, Michnich ME, Friedlander L, Gilson B, Grothaus LC, Storer B. Effectiveness of smoking cessation interventions integrated into primary care practice. Medical Care 1988;26:62-76.

\section{van der Aalst 2012 \{published data only\}}

van der Aalst CM, de Koning $\mathrm{HJ}$, van den Bergh KA, Willemsen MC, van Klaveren RJ. The effectiveness of a computer-tailored smoking cessation intervention for participants in lung cancer screening: a randomised controlled trial. Lung Cancer (Amsterdam, Netherlands) 2012;76(2):204-10. [CENTRAL: 830557; CRS: 9400123000012567 ; EMBASE: 2012198268; PUBMED: 22054915]

\section{Velicer 1999 \{published data only\}}

Velicer WF, Prochaska JO. An expert system intervention for smoking cessation. Patient Education \& Counseling 1999;36:119-29.

* Velicer WF, Prochaska JO, Fava JL, Laforge RG, Rossi JS. Interactive versus noninteractive interventions and doseresponse relationships for stage-matched smoking cessation programs in a managed care setting. Health Psychology 1999;18(1):21-8.

\section{Velicer 2006 \{published data only\}}

Velicer WF, Friedman RH, Fava JL, Gulliver SB, Keller S, Sun X, et al. Evaluating nicotine replacement therapy and stage-based therapies in a population-based effectiveness trial. Journal of Consulting and Clinical Psychology 2006;74(6):1162-72.

Webb 2013 \{published data only\}

Webb Hooper M, Rodriguez De Ybarra D, Baker EA. The effect of placebo tailoring on smoking cessation: a randomized controlled trial. Journal of Consulting and Clinical Psychology 2013;81(5):800-9. [CENTRAL: 875034; CRS: 9400126000000237 ; EMBASE: 2013603080; PUBMED: 23544680]

Willemsen 2006 \{published data only\}

* Willemsen MC, Wiebing M, Van Emst A, Zeeman G. Helping smokers to decide on the use of efficacious smoking cessation methods: a randomized controlled trial of a decision aid. Addiction 2006;101(3):441-9.

Willemsen MC, Wiebing MA, van Ernst AJ, Zeeman G. A selfhelp quit kit to motivate smokers to undergo treatment: a randomised controlled trial. Society for Research on Nicotine and Tobacco 11th Annual Meeting. 20-23 March 2005; Prague, Czech Republic. 2005.

\section{References to studies excluded from this review}

\section{Ainsworth 2013 \{published data only\}}

Ainsworth H, Shah S, Ahmed F, Amos A, Cameron I, Fairhurst C, et al. Muslim communities learning about second-hand smoke (MCLASS): study protocol for a pilot cluster randomised controlled trial. Trials 2013;14:295.

\section{Armitage 2008a \{published data only\}}

Armitage CJ, Arden MA. How useful are the stages of change for targeting interventions? Randomized test of a brief intervention to reduce smoking. Health Psychology 2008;27(6):789-98. [CENTRAL: 754030; CRS: 9400123000005686 ; EMBASE: 2008603965]

\section{Armitage 2008b \{published data only\}}

Armitage CJ. A volitional help sheet to encourage smoking cessation: a randomized exploratory trial. Health Psychology 2008;27:557-66.

\section{Arnold 2009 \{published data only\}}

Arnold J, Goodacre S, Bath P, Price J. Information sheets for patients with acute chest pain: randomised controlled trial. BMJ (Clinical Research Ed.) 2009;338:b541. [CENTRAL: 682280; CRS: 9400123000005097; EMBASE: 2009155221; PUBMED: 19246544]

\section{Balanda 1999 \{published data only\}}

Balanda KP, Lowe JB, OConnor Fleming ML. Comparison of two self-help smoking cessation booklets. Tobacco Control 1999;8:57-61.

\section{Bansal-Travers 2010 \{published data only\}}

Bansal-Travers M, Cummings KM, Hyland A, Brown A, Celestino P. Educating smokers about their cigarettes and nicotine medications. Health Education Research 
2010;25(4):678-86. [CENTRAL: 759258; CRS: 9400123000005725 ; PUBMED: 20064838]

\section{Barnett 2015 \{published data only\}}

Barnett PG, Wong W, Jeffers A, Hall SM, Prochaska JJ. Cost-effectiveness of smoking cessation treatment initiated during psychiatric hospitalization: analysis from a randomized, controlled trial. Journal of Clinical Psychiatry 2015;76(10):e1285-91.

\section{Brandon 2000 \{published data only\}}

Brandon TH, Collins BN, Juliano LM, Lazev AB. Preventing relapse among former smokers: a comparison of minimal interventions through telephone and mail. Journal of Consulting and Clinical Psychology 2000;68:103-13.

\section{Brandon 2004 \{published data only\}}

Brandon TH, Meade CD, Herzog TA, Chirikos TN, Webb MS, Cantor AB. Efficacy and cost-effectiveness of a minimal intervention to prevent smoking relapse: dismantling the effects of amount of content versus contact. Journal of Consulting and Clinical Psychology 2004;72(5):797-808.

\section{Brandon 2012 \{published data only\}}

Brandon TH, Simmons VN, Meade CD, Quinn GP, Lopez Khoury EN, Sutton SK, et al. Self-help booklets for preventing postpartum smoking relapse: a randomized trial. American Journal of Public Health 2012;102(11):2109-15. [CENTRAL: 867762; CRS: 9400123000017587 ; EMBASE: 22994170; PUBMED: 22994170]

\section{Brown 1992 \{published data only\}}

Brown S, Hunt G, Owen N. The effect of adding telephone contact to self-instructional smoking-cessation materials. Behavior Change 1992;9:216-22.

\section{Burling 2000 \{published data only\}}

Burling AS, Burling TA. A work in progress: effectiveness of a comprehensive internet-delivered interactive multimedia stop smoking program. Presented at the 34th Annual Convention of the Association for the Advancement of Behavior Therapy, New Orleans, LA, November 2000.

\section{Carré 2008 \{published data only\}}

Carré PC, Roche N, Neukirch F, Radeau T, Perez T, Terrioux P, et al. The effect of an information leaflet upon knowledge and awareness of COPD in potential sufferers. A randomized controlled study. Respiration; International Review of Thoracic Diseases 2008;76(1):53-60. [CENTRAL: 647637; CRS: 9400123000004868; PUBMED: 18253024]

\section{Conway 2004 \{published data only\}}

Conway TL, Woodruff SI, Edwards CC, Elder JP, Hurtado SL, Hervig LK. Operation Stay Quit: evaluation of two smoking relapse prevention strategies for women after involuntary cessation during US Navy recruit training. Military Medicine 2004;169(3):236-42.

\section{Curry 1988 \{published data only\}}

Curry SJ, Marlatt GA, Gordon J, Baer JS. A comparison of alternative theoretical approaches to smoking cessation and relapse. Health Psychology 1988;7:545-56.

Dijkstra 1998b \{published data only\}

Dijkstra A, de Vries H, Roijackers J, Van Breukelen G. Tailoring information to enhance quitting in smokers with low motivation to quit: three basic efficacy questions. Health Psychology 1998;17:513-9.

\section{Dijkstra 2001 \{published data only\}}

Dijkstra A, de Vries H. Do self-help interventions in health education lead to cognitive changes, and do cognitive changes lead to behavioural change?. British Journal of Health Psychology 2001;6:121-34.

\section{Dijkstra 2005 \{published data only\}}

Dijkstra A. Working mechanisms of computer-tailored health education: evidence from smoking cessation. Health Education Research 2005;20(5):527-39.

\section{Dijkstra 2006 \{published data only\}}

Dijkstra A, Conijn B, De Vries H. A field experiment on stages of change for smoking cessation: the effects of matched and mismatched information. Psychologie \& Gezondheid 2007;35(1):5-16.

* Dijkstra A, Conijn B, de Vries H. A match-mismatch test of a stage model of behaviour change in tobacco smoking. Addiction 2006;101(7):1035-43.

\section{Dijkstra 2009 \{published data only\}}

Dijkstra A. Disengagement beliefs in smokers: do they influence the effects of a tailored persuasive message advocating smoking cessation?. Psychology \& Health 2009;24(7):791-804. [CENTRAL: 752163; CRS: $9400123000005663 ;$ PUBMED: 20205027]

\section{Edwards 1999 \{published data only\}}

Edwards CC, Woodruff SI, Conway TL. Operation Stay Quit: preventing smoking relapse among US Navy women. American Journal of Health Behavior 1999;23:352-5.

\section{Emmons 2013 \{published data only\}}

Emmons KM, Puleo E, Sprunck-Harrild K, Ford J, Ostroff JS, Hodgson D, et al. Partnership for health-2, a web-based versus print smoking cessation intervention for childhood and young adult cancer survivors: randomized comparative effectiveness study. Journal of Medical Internet Research 2013;15(11):e218. [CRS: 9400126000000377; PUBMED: 24195867]

\section{Etter 2007 \{published data only\}}

Etter JF. Informing smokers on additives in cigarettes: a randomized trial. Patient Education \& Counseling 2007;66(2):188-91.

\section{Fortmann 1995 \{published and unpublished data\}}

Fortmann SP, Killen JD. Nicotine gum and self-help behavioral treatment for smoking relapse prevention - results from a trial 
using population-based recruitment. Journal of Consulting and Clinical Psychology 1995;63:460-8.

\section{Garcia 2000 \{published data only\}}

Garcia MP, Becona E. Evaluation of the amount of therapist contact in a smoking cessation program. Spanish Journal of Psychology 2000;3(1):28-36.

Gritz 1988 \{published data only\}

Gritz ER, Marcus AC, Berman BA, Read LL, Kanim LEA, Reeder SJ. Evaluation of a worksite self-help smoking cessation program for registered nurses. American Journal of Health Promotion 1988;3(2):26-35.

\section{Hall 2003 \{published data only\}}

* Hall S, Bishop AJ, Marteau TM. Increasing readiness to stop smoking in women undergoing cervical screening: evaluation of two leaflets. Nicotine \& Tobacco Research 2003;5(6):821-6.

Marteau TM, Hall S. Motivating smoking cessation in women undergoing cervical screening: evaluation of two leaflets. International Journal of Cancer 2002;Suppl 13:469.

\section{Jeffery 1982 \{published data only\}}

Jeffery RW, Danaher BG, Killen J, Farquhar JW, Kinnier R. Selfadministered programs for health behavior change: smoking cessation and weight reduction by mail. Addictive Behaviors 1982; 7:57-63.

\section{Jeffery 1990 \{published data only\}}

Jeffery RW, Hellerstedt WL, Schmid TL. Correspondence programs for smoking cessation and weight control: a comparison of two strategies in the Minnesota Heart Health Program. Health Psychology 1990;9:585-98.

\section{Johs 2003 \{published data only\}}

Johs Artisensi JL. The effect of web-based support as an adjunct to a self-help smoking cessation program. Dissertation Abstracts International: Section B: The Sciences and Engineering 2003;63(9-B):4138.

\section{Jordan 1999 \{published data only\}}

Jordan JC, Reynolds RV, Myers DL, Tobin TL, Jones JR, Hall LK, et al. Comparison of internet delivered and printed self-help smoking cessation programs with hospital employees. Society for Research on Nicotine and Tobacco Fifth Annual Meeting March 5-7 San Diego CA. 1999.

Killen 1990 \{published data only\}

Fortmann SP, Killen JD, Telch MJ, Newman B. Minimal contact treatment for smoking cessation. A placebo controlled trial of nicotine polacrilex and self-directed relapse prevention: initial results of the Stanford Stop Smoking Project. JAMA 1988;260:1575-80.

* Killen JD, Fortmann SP, Newman B, Varady A. Evaluation of a treatment approach combining nicotine gum with self-guided behavioral treatments for smoking relapse prevention. Journal of Consulting and Clinical Psychology 1990;58:85-92.
Kreuter 1996 \{published data only\}

Kreuter MW, Strecher VJ. Do tailored behavior change messages enhance the effectiveness of health risk appraisal? Results from a randomized trial. Health Education Research 1996;11:97-105.

Kreuter 2012 \{published data only\}

Kreuter MW, Eddens KS, Alcaraz KI, Rath S, Lai C, Caito N, et al. Use of cancer control referrals by 2-1-1 callers: a randomized trial. American Journal of Preventive Medicine 2012;43(6 Suppl 5):S425-34. [CRS: 9400107000000806 ; PEER: Reviewed Journal: 2012-31259-006]

\section{Lenert 2004 \{published data only\}}

Lenert L, Munoz RF, Perez JE, Bansod A. Automated e-mail messaging as a tool for improving quit rates in an internet smoking cessation intervention. Journal of the American Medical Informatics Association 2004;11(4):235-40.

\section{Lipkus 2004 \{published data only\}}

Lipkus IM, McBride CM, Pollak KI, Schwartz-Bloom RD, Tilson E, Bloom PN. A randomized trial comparing the effects of self-help materials and proactive telephone counseling on teen smoking cessation. Health Psychology 2004;23(4):397-406.

McBride 1999 \{published data only\}

* McBride CM, Scholes D, Grothaus LC, Curry SJ, Ludman E, Albright J. Evaluation of a minimal self-help smoking cessation intervention following cervical cancer screening. Preventive Medicine 1999;29(2):133-8.

\section{McDonald 2003 \{published data only\}}

McDonald PW, Jessup L, Stephen Brown K, Ahmed R, Filsinger S. Are cessation interventions based on stage of change really more effective? (POS4-27). Society for Research on Nicotine and Tobacco 9th Annual Meeting February 19-22 New Orleans, Louisiana. 2003.

\section{McDonnell 2011 \{published data only\}}

* McDonnell DD, Kazinets G, Lee HJ, Moskowitz JM. An internet-based smoking cessation program for Korean Americans: results from a randomized controlled trial. Nicotine \& Tobacco Research 2011;13(5):336-43. [CENTRAL: 831359; CRS 9400123000011568; 135; PUBMED: 21330285]

McDonnell DD, Lee HJ, Kazinets G, Moskowitz JM. Online recruitment of targeted populations: lessons learned from a smoking cessation study among Korean Americans. Social Marketing Quarterly 2010;16(3):2-22. [CENTRAL: 794867; CRS: 9400123000006106]

\section{McMahon 2000 \{published data only\}}

McMahon SD, Jason LA. Social support in a worksite smoking intervention. A test of theoretical models. Behavior Modification 2000;24:184-201.

\section{Meade 1989 \{published data only\}}

Meade CD, Byrd JC, Lee M. Improving patient comprehension of literature on smoking. American Journal of Public Health 1989;79(10):1411-2. 
Moore 2002 \{published data only\}

Moore L, Campbell R, Whelan A, Mills N, Lupton P, Misselbrook E, et al. Self help smoking cessation in pregnancy: cluster randomised controlled trial. BMJ 2002;325(7377):1383.

\section{Murphy 2005 \{published data only\}}

Murphy JM, Mahoney MC, Cummings KM, Hyland AJ, Lawvere S. A randomized trial to promote pharmacotherapy use and smoking cessation in a Medicaid population (United States). Cancer Causes and Control 2005;16(4):373-82.

\section{Naughton 2012 \{published data only\}}

Naughton F, Prevost AT, Gilbert H, Sutton S. Randomized controlled trial evaluation of a tailored leaflet and SMS text message self-help intervention for pregnant smokers (MiQuit). Nicotine \& Tobacco Research 2012;14(5):569-77. [CENTRAL: 832524; CRS: 9400123000014482 ; EMBASE: 2012254938; 334; PUBMED: 22311960]

\section{NCT00714467 \{published data only\}}

NCT00714467. Expert system and family assisted interventions for chinese smokers. ClinicalTrials.gov/show/NCT00714467 2004.

\section{NCT01566994 \{published data only\}}

NCT01566994. Comparing population cessation services. ClinicalTrials.gov/show/NCT01566994 2010.

\section{O'Hara 1993 \{published data only\}}

O'Hara P, Gerace TA, Elliott LL. Effectiveness of self-help smoking cessation guides for firefighters. Journal of Occupational Medicine 1993;35:795-9.

\section{Ossip-Klein 1991 \{published data only\}}

Ossip Klein DJ, Giovino GA, Megahed N, Black PM, Emont SL, Stiggins J, et al. Effects of a smoker's hotline: results of a 10-county self-help trial. Journal of Consulting and Clinical Psychology 1991;59:325-32.

\section{Ossip-Klein 1997 \{published data only\}}

Ossip Klein DJ, Carosella AM, Krusch DA. Self-help interventions for older smokers. Tobacco Control 1997;6(3):188-93.

\section{Pallonen 1998 \{published data only\}}

* Pallonen UE, Velicer WF, Prochaska JO, Rossi JS, Bellis JM, Tsoh JY, et al. Computer-based smoking cessation interventions in adolescents: description, feasibility, and six-month follow-up findings. Substance Use and Misuse 1998;33(4):935-65.

\section{Pederson 1981 \{published data only\}}

Pederson LL, Baldwin N, Lefcoe NM. Utility of behavioral selfhelp manuals in a minimal-contact smoking cessation program. International Journal of Addiction 1981;16:1233-9.

\section{Rimer 1994 \{published data only\}}

Rimer BK, Orleans CT. Tailoring smoking cessation for older adults. Cancer 1994;74(7 Suppl):2051-4.

* Rimer BK, Orleans CT, Fleisher L, Cristinzio S. Does tailoring matter? The impact of a tailored guide on ratings and short- term smoking-related outcomes for older smokers. Health Education Research 1994;9:69-84.

Russell 1979 \{published data only\}

Russell MAH, Wilson C, Taylor C, Baker CD. Effect of general practitioners' advice against smoking. British Medical Journal 1979;2:231-5.

\section{Sallis 1986 \{published data only\}}

Sallis JF, Hill RD, Killen JD, Telch MJ, Flora JA, Girard J, et al. Efficacy of self-help behavior modification materials in smoking cessation. American Journal of Preventive Medicine 1986;2:342-4

\section{Senesael 2013 \{published data only\}}

Senesael E, Borgermans L, Van De Vijver E, Devroey D. Effectiveness of a quality improvement intervention targeting cardiovascular risk factors: are patients responsive to information and encouragement by mail or post?. Vascular Health and Risk Management 2013;9:13-20. [CENTRAL: 862212; CRS: 9400107000001662; PUBMED: 23426275]

\section{Shi 2013 \{published data only\}}

Shi HJ, Jiang XX, Yu CY, Zhang Y. Use of mobile phone text messaging to deliver an individualized smoking behaviour intervention in Chinese adolescents. Journal of Telemedicine and Telecare 2013;19(5):282-7. [CRS: 9400126000000380 ; PUBMED: 24163238]

\section{Shiffman 2000 \{unpublished data only\}}

Shiffman S, Gitchell J, Strecher V, et al. Real-world efficacy of computer-tailored smoking cessation material as a supplement to nicotine replacement [Abstract]. 10th World Congress on Smoking or Health, Beijing, China, August. 1997.

* Shiffman S, Paty JA, Rohay JM, Dimarino ME, Gitchell J. The efficacy of computer-tailored smoking cessation material as a supplement to nicotine polacrilex gum therapy. Archives of Internal Medicine 2000;160:1675-81.

\section{Shiffman 2001 \{unpublished data only\}}

Shiffman S, Paty J, Rohay J, di Marino M, Strecher V. The efficacy of computer-tailored smoking cessation material as a supplement to nicotine patch therapy. Society for Research on Nicotine and Tobacco; 1998 August; Copenhagen, Denmark.

* Shiffman S, Paty JA, Rohay JM, Di Marino ME, Gitchell JG. The efficacy of computer-tailored smoking cessation material as a supplement to nicotine patch therapy. Drug \& Alcohol Dependence 2001;64(1):35-46.

\section{Sims 2013 \{published data only\}}

Sims TH, McAfee T, Fraser DL, Baker TB, Fiore MC, Smith SS. Quitline cessation counseling for young adult smokers: a randomized clinical trial. Nicotine \& Tobacco Research 2013;15(5):932-41. [CRS: 9400123000018624 ; EMBASE: 2013286046]

\section{Song 2012 \{published data only\}}

Blyth A, Maskrey V, Notley C, Barton GR, Brown TJ, Aveyard P, et al. Effectiveness and economic evaluation of self-help educational materials for the prevention of smoking relapse: 
randomised controlled trial. Health Technology Assessment 2015;19(59):1-70. [CNO: CN-01170619]

Song F, Holland R, Barton GR, Bachmann M, Blyth A, Maskrey V, et al. Self-help materials for the prevention of smoking relapse: study protocol for a randomized controlled trial. Trials 2012;13:69. [CENTRAL: 855130; CRS: 9400123000017475 ; EMBASE: 2012625152; 316; PUBMED: 22647290]

Song F, Maskrey V, Blyth A, Brown TJ, Barton GR, Aveyard P, et al. Differences in longer-term smoking abstinence after treatment by specialist or nonspecialist advisors: secondary analysis of data from a relapse prevention trial. Nicotine \& Tobacco Research 2016;18(5):1061-6. [CNO: CN-01215184]

\section{Stanczyk 2013 \{published data only\}}

Stanczyk NE, Crutzen R, Bolman C, Muris J, de Vries H. Influence of delivery strategy on message-processing mechanisms and future adherence to a Dutch computer-tailored smoking cessation intervention. Journal of Medical Internet Research 2013;15(2):e28. [CENTRAL: 873085; CRS: 9400107000001436 ; PEER: Reviewed Journal: 2013-26866-003; PUBMED: 23388554]

\section{Strecher 1994 \{published data only\}}

Strecher VJ, Kreuter M, den Boer DJ, Kobrin S, Hospers HJ, Skinner CS. The effects of computer-tailored smoking cessation messages in family practice settings. Journal of Family Practice 1994;39:262-70.

\section{Strecher 2000 \{published data only\}}

Strecher VJ, Bishop KR, Bernhardt J, Thorp JM, Cheuvront B, Potts P. Quit for keeps: tailored smoking cessation guides for pregnancy and beyond. Tobacco Control 2000;9 Suppl 3:78-9.

\section{Strecher 2005b \{published data only\}}

Strecher VJ, Shiffman S, West R. Randomized controlled trial of a web-based computer-tailored smoking cessation program as a supplement to nicotine patch therapy. Addiction 2005;100:682-8.

\section{Strecher 2008 \{published data only\}}

Strecher VJ, McClure JB, Alexander GL, Chakraborty B, Nair VN, Konkel JM, et al. Web-based smoking-cessation programs: results of a randomized trial. American Journal of Preventive Medicine 2008;34(5):373-81.

\section{Te Poel 2009 \{published data only\}}

Te Poel F, Bolman C, Reubsaet A, de Vries H. Efficacy of a single computer-tailored e-mail for smoking cessation: results after 6 months. Health Education Research 2009;24(6):930-40. [CENTRAL: 733113; CRS: $9400123000005498 ;$ PUBMED: 19574405]

\section{Travis 2004 \{published data only\}}

Travis HE, Lawrance K. Effectiveness of self-help smoking cessation interventions for college smokers: a randomized controlled trial (POS2-032). Society for Research on Nicotine and Tobacco 10th Annual Meeting February 18-21, Phoenix, Arizona. 2004.

\section{Travis 2009 \{published data only\}}

Travis HE, Lawrance KA. Randomized controlled trial examining the effectiveness of a tailored self-help smoking-cessation intervention for postsecondary smokers. Journal of American College Health 2009;57(4):437-44. [CENTRAL: 683030; CRS: 9400123000005106; PUBMED: 19114383]

Ussher 2011 \{published data only\}

Ussher M, Chambers M, Adams R, Croghan E, Murray R. Evaluation of a nationally disseminated self-help intervention for smoking cessation ('Quit Kit'). Tobacco Control 2011;20(5):380-2. [CRS: 9400123000012921; EMBASE: 21415063; 31695]

Webb 2005 \{published data only\}

Webb MS, Simmons VN, Brandon TH. Tailored interventions for motivating smoking cessation: using placebo tailoring to examine the influence of expectancies and personalization. Health Psychology 2005;24(2):179-88.

Webb 2007 \{published data only\}

Webb MS, Hendricks PS, Brandon TH. Expectancy priming of smoking cessation messages enhances the placebo effect of tailored interventions. Health Psychology 2007;26(5):598-609.

Webb 2008 \{published data only\}

Webb MS. Does one size fit all African American smokers? The moderating role of acculturation in culturally specific interventions. Psychology of Addictive Behaviors 2008;22(4):592-6. [CENTRAL: 665144; CRS: 9400123000004966 ; PUBMED: 19071987]

\section{Webb 2009 \{published data only\}}

Webb MS. Culturally specific interventions for African American smokers: an efficacy experiment. Journal of the National Medical Association 2009;101(9):927-35. [CENTRAL: 749773; CRS: 9400123000005621; EMBASE: 2009543758; PUBMED: 19806851]

\section{Webb 2010 \{published data only\}}

Webb MS, Baker EA, Rodríguez de Ybarra D. Effects of culturally specific cessation messages on theoretical antecedents of behavior among low-income African American smokers. Psychology of Addictive Behaviors 2010;24(2):333-41. [CENTRAL: 762147; CRS: 9400123000005767 ; PUBMED: 20565159]

\section{Weissfeld 1991 \{published data only\}}

Weissfeld JL, Holloway JL. Treatment for cigarette smoking in a department of Veterans Affairs outpatient clinic. Archives of Internal Medicine 1991;151:973-7.

\section{Wetter 2011 \{published data only\}}

Wetter DW, McClure JB, Cofta-Woerpel L, Costello TJ, Reitzel LR, Businelle MS, et al. A randomized clinical trial of a palmtop computer-delivered treatment for smoking relapse prevention among women. Psychology of Addictive Behaviors 2011;25(2):365-71. [CENTRAL: 800597; CRS: 9400123000011588 ; PUBMED: 21500879]

\section{Willemsen 1995 \{published data only\}}

Willemsen MC, de Vries H. Evaluation of a smoking cessation intervention for Dutch employees consisting of self 
help methods and a group programme. Tobacco Control 1995;4:351-64.

Windsor 1989 \{published data only\}

Windsor RA, Lowe JB. Behavioral impact and cost analysis of a worksite self-help smoking cessation program. Progress in Clinical and Biological Research 1989;293:231-42.

\section{Zhu 1996 \{published data only\}}

Zhu SH, Stretch V, Balabanis M, Rosbrook BP, Sadler G, Pierce JP. Telephone counseling for smoking cessation - effects of single-session and multiple-session interventions. Journal of Consulting and Clinical Psychology 1996;64:202-11.

\section{References to studies awaiting assessment}

Campos 2014 \{published data only (unpublished sought but not used)\}

Campos ACF, Martins LVO, Yano RN, Alvim RNT, Silva EN, Silva VA, et al. Comparison of two strategies for smoking cessation in hospitalized patients. European Heart Journal 2014;35:903.

Oh 2013 \{published data only (unpublished sought but not used)\} Oh A, Luginbuhl A, Curry J, Cognetti DM. Prospective randomized control trial using best-selling smoking cessation book. Otolaryngology - Head and Neck Surgery 2013;2 Suppl:188.

Pereira 2017 \{published data only (unpublished sought but not used)\}

Pereira LS, Madureira MF, Lamas MFM, Brum DA, Sobreira NP, Pereira NS, et al. Making the decision to quit smoking: impact of interactive and educational video applied in population with multimorbidities. 22nd World Congress on Heart Disease International Academy of Cardiology Annual Scientific Sessions. 2017; Vol. 137:234.

\section{References to ongoing studies}

\section{JPRN-UMIN000008750 \{published data only\}}

JPRN-UMIN000008750. A randomized study of bibliotherapy for smoking cessation with and without focusing on cognitive elements. https://upload.umin.ac.jp/cgi-open-bin/ctr/ctr.cgi? function=brows\&action=brows\&recptno=R000010276\&type=sum 2012.

\section{NCT01544010 \{unpublished data only\}}

Redding CA, Prochaska JO, Rossi JS, Kobayashi H, Yin HQ, Paiva AL, et al. Levels of transtheoretical model tailoring for cessation: randomized trial outcomes. Annals of Behavioral Medicine 2014;47:S238.

\section{NCT02276664 \{published data only\}}

NCT02276664. Capitalizing on a teachable moment to promote smoking cessation. clinicaltrials.gov/ct2/show/NCT02276664 2014.
NCT02416011 \{published data only\}

Meltzer LR, Simmons VN, Sutton SK, Drobes DJ, Quinn GP, Meade $C D$, et al. A randomized controlled trial of a smoking cessation self-help intervention for dual users of tobacco cigarettes and E-cigarettes: intervention development and research design. Contemporary Clinical Trials 2017;60:56-62.

NCT02611076 \{published data only\}

NCT02611076. Smoking-cessation: a Spanish-language clinical trial. clinicaltrials.gov/ct2/show/NCT02611076 2015.

\section{NCT02945787 \{published data only\}}

NCT02945787. Spanish-language smoking cessation trial. clinicaltrials.gov/ct2/show/NCT02945787 2016.

NCT03064971 \{published data only\} NCT03064971. Enhancing quitline services for African American smokers. https://ClinicalTrials.gov/show/NCT03064971 2017.

\section{Additional references}

\section{Chamberlain 2017}

Chamberlain C, O'Mara-Eves A, Porter J, Coleman T, Perlen SM, Thomas J, et al. Psychosocial interventions for supporting women to stop smoking in pregnancy. Cochrane Database of Systematic Reviews 2017, Issue 2. [DOI: 10.1002/14651858.CD001055.pub5]

\section{Coleman 2015}

Coleman T, Chamberlain C, Davey MA, Cooper SE, Leonardi-Bee J. Pharmacological interventions for promoting smoking cessation during pregnancy. Cochrane Database of Systematic Reviews 2015, Issue 12. [DOI: 10.1002/14651858.CD010078.pub2]

\section{Curry 1993}

Curry SJ. Self-help interventions for smoking cessation. Journal of Consulting and Clinical Psychology 1993;61:790-803.

\section{Fanshawe 2017}

Fanshawe TR, Halliwell W, Lindson N, Aveyard P, LivingstoneBanks J, Hartmann-Boyce J. Tobacco cessation interventions for young people. Cochrane Database of Systematic Reviews 2017, Issue 11. [DOI: 10.1002/14651858.CD003289.pub6]

\section{Hajek 2013}

Hajek P, Stead LF, West R, Jarvis M, Hartmann-Boyce J, Lancaster T. Relapse prevention interventions for smoking cessation. Cochrane Database of Systematic Reviews 2013, Issue 8. [DOI: 10.1002/14651858.CD003999.pub4]

\section{Hall 2001}

Hall SM, Delucchi KL, Velicer WF, Kahler CW, Ranger-Moore J, Hedeker D, et al. Statistical analysis of randomized trials in tobacco treatment: longitudinal designs with dichotomous outcome. Nicotine \& Tobacco Research 2001;3:193-202.

\section{Hartmann-Boyce 2018}

Hartmann-Boyce J, Chepkin SC, Ye W, Bullen C, Lancaster T. Nicotine replacement therapy versus control for smoking 
cessation. Cochrane Database of Systematic Reviews 2018, Issue 5. [DOI: 10.1002/14651858.CD000146.pub5]

\section{Higgins 2003}

Higgins JPT, Thompson SG, Deeks JJ, Altman DG. Measuring inconsistency in meta-analysis. BMJ 2003;327:557-60.

\section{Higgins 2011}

Higgins JPT, Greene S (editors). Cochrane Handbook for Systematic Reviews of Interventions Version 5.1.0 (updated March 2011). The Cochrane Collaboration, 2011. Available from www.cochrane-handbook.org.

\section{Koshy 2008}

Koshy E, Marlais M, Civljak M. Internet-based interventions for smoking cessation. Cochrane Database of Systematic Reviews 2008, Issue 2. [DOI: 10.1002/14651858.CD007078]

\section{Kreuter 2000}

Kreuter MW, Skinner CS. Tailoring: what's in a name?. Health Education Research 2000;15:1-4.

\section{Lancaster 2017}

Lancaster T, Stead LF. Individual behavioural counselling for smoking cessation. Cochrane Database of Systematic Reviews 2017, Issue 3. [DOI: 10.1002/14651858.CD001292.pub3]

\section{Lee 2007}

Lee C-W, Kahende J. Factors associated with successful smoking cessation in the United States, 2000. American Journal of Public Health 2007;97(8):1503-9.

\section{Marks 2002}

Marks DF, Sykes CM. Randomized controlled trial of cognitive behavioural therapy for smokers living in a deprived area of London: outcome at one-year follow-up. Psychology, Health and Medicine 2002;7:17-24.

\section{Park 2004}

Park EW, Schultz JK, Tudiver FG, Campbell T, Becker LA. Enhancing partner support to improve smoking cessation. Cochrane Database of Systematic Reviews 2004, Issue 3. [DOI: 10.1002/14651858.CD002928.pub2]

\section{Stead 2013a}

Stead LF, Buitrago D, Preciado N, Sanchez G, HartmannBoyce J, Lancaster T. Physician advice for smoking cessation. Cochrane Database of Systematic Reviews 2013, Issue 5. [DOI: 10.1002/14651858.CD000165.pub4]

\section{Stead 2013b}

Stead LF, Hartmann-Boyce J, Perera R, Lancaster T. Telephone counselling for smoking cessation. Cochrane Database of Systematic Reviews 2013, Issue 8. [DOI: 10.1002/14651858.CD002850.pub3]

\section{Stead 2017}

Stead LF, Carroll AJ, Lancaster T. Group behaviour therapy programmes for smoking cessation. Cochrane
Database of Systematic Reviews 2017, Issue 3. [DOI: 10.1002/14651858.CD001007.pub3]

\section{Taylor 2017}

Taylor GMJ, Dalili M, Semwal M, Civljak M, Sheikh A, Car J. Internet-based interventions for smoking cessation. Cochrane Database of Systematic Reviews 2017, Issue 9. [DOI: 10.1002/14651858.CD007078.pub5]

\section{Whittaker 2016}

Whittaker R, McRobbie H, Bullen C, Rodgers A, Gu Y. Mobile phone-based interventions for smoking cessation. Cochrane Database of Systematic Reviews 2016, Issue 4. [DOI: 10.1002/14651858.CD006611.pub4]

\section{WHO 2012}

World Health Organization. WHO Global Report: Mortality Attributable to Tobacco. Geneva, Switzerland: World Health Organization, 2012.

\section{WHO 2017}

World Health Organization. WHO Report on the Global Tobacco Epidemic: Monitoring Tobacco Use and Prevention Policies. Geneva, Switzerland: World Health Organization, 2017.

\section{References to other published versions of this review Hartmann-Boyce 2014}

Hartmann-Boyce J, Lancaster T, Stead LF. Print-based self-help interventions for smoking cessation. Cochrane Database of Systematic Reviews 2014, Issue 6. [DOI: 10.1002/14651858.CD001118.pub3]

\section{Lancaster 1998}

Lancaster T, Stead LF. Self-help interventions for smoking cessation. Cochrane Database of Systematic Reviews 1998, Issue 4.

\section{Lancaster 2000}

Lancaster T, Stead LF. Self-help interventions for smoking cessation. Cochrane Database of Systematic Reviews 2000, Issue 1.

\section{Lancaster 2002}

Lancaster T, Stead LF. Self-help interventions for smoking cessation. Cochrane Database of Systematic Reviews 2002, Issue 3. [DOI: 10.1002/14651858.CD001118]

\section{Lancaster 2005a}

Lancaster T, Stead LF. Self-help interventions for smoking cessation. Cochrane Database of Systematic Reviews 2005, Issue 3. [DOI: 10.1002/14651858.CD001118.pub2]

* Indicates the major publication for the study 
CHARACTERISTICS OF STUDIES

Characteristics of included studies [ordered by study ID]

Aveyard 2003

\begin{tabular}{ll} 
Methods & $\begin{array}{l}\text { Setting: } 65 \text { general practices, UK } \\
\text { Recruitment: volunteers from random selection of smoking patients; not selected for motivation }\end{array}$ \\
\hline Participants & $\begin{array}{l}2471 \text { smokers, } 1373 \text { in relevant arms, }>80 \% \text { in pre-contemplation or contemplation, } 10 \% \text { to } 14 \% \text { in } \\
\text { preparation } \\
54 \% \text { female, average age } 41, \text { average cpd } 20\end{array}$ \\
\hline Interventions & $\begin{array}{l}\text { No face-to-face contact } \\
\cdot \text { Standard self-help materials, single mailing } \\
\text { Self-help manual based on transtheoretical (SoC) model; expert system letter tailored on baseline } \\
\text { questionnaire. Further questionnaires at } 3 \text { months and } 6 \text { months for additional letters (approximately } \\
50 \% \text { received } 3 \text { letters) }\end{array}$
\end{tabular}

\begin{tabular}{ll}
\hline Outcomes & $\begin{array}{l}\text { Abstinence at } 12 \text { months, sustained for } 6 \text { months } \\
\text { Validation: saliva cotinine }<14.2 \mathrm{ng} / \mathrm{mL}\end{array}$ \\
\hline Notes & 2 vs 1 ; tailored self-help vs standard self-help \\
\hline
\end{tabular}

\section{Risk of bias}

\begin{tabular}{|c|c|c|}
\hline Bias & Authors' judgement & Support for judgement \\
\hline $\begin{array}{l}\text { Random sequence genera- } \\
\text { tion (selection bias) }\end{array}$ & Low risk & $\begin{array}{l}\text { Randomisation using minimisation to balance SoC, addiction, and socioeco- } \\
\text { nomic status }\end{array}$ \\
\hline $\begin{array}{l}\text { Allocation concealment } \\
\text { (selection bias) }\end{array}$ & Low risk & $\begin{array}{l}\text { Baseline questionnaires read optically and data transferred automatically to } \\
\text { the Access database, which performed the minimisation }\end{array}$ \\
\hline \multirow{3}{*}{$\begin{array}{l}\text { Blinding (performance } \\
\text { bias and detection bias) } \\
\text { All outcomes }\end{array}$} & Low risk & Interventions of similar intensity \\
\hline & & $\begin{array}{l}12 \text { months: abstinence "was confirmed with salivary cotinine, so that we had } \\
\text { unconfirmed and confirmed prevalence of quitting" }\end{array}$ \\
\hline & & Confirmed figures used in analysis \\
\hline $\begin{array}{l}\text { Incomplete outcome data } \\
\text { (attrition bias) }\end{array}$ & Low risk & $24 \%$ of self-help and $24 \%$ of control lost to follow-up \\
\hline All outcomes & & $\begin{array}{l}\text { Included in ITT analysis here; sensitivity analyses allowing for differential } \\
\text { dropout did not change findings }\end{array}$ \\
\hline
\end{tabular}

Becona 2001a

\begin{tabular}{ll}
\hline Methods & $\begin{array}{l}\text { Setting: community, Spain } \\
\text { Recruitment: community volunteers, mainly in contemplation or preparation SoC }\end{array}$ \\
\hline Participants & $\begin{array}{l}300 \text { smokers } \\
48 \% \text { female, average age } 37, \text { average cpd } 26\end{array}$ \\
\hline Interventions & $\cdot$ No intervention; treatment offered after 6 months' follow-up \\
& $\cdot$ Standard self-help pamphlets; 6 mailed weekly with personalised letter \\
& 2 with individual feedback based on weekly reports plus 2 additional 1-page reports
\end{tabular}


Becona 2001a (Continued)

Outcomes Abstinence at 6 months or 12 months, sustained since initial quit Validation: $\mathrm{CO}<9 \mathrm{ppm}$

Notes

2 vs 1 , self-help vs control; excluded from Analysis 2.1 because of heterogeneity; quit rates $16 \%$ vs $0 \%$ at 6 months

3 vs 2, 12-month outcome; tailored materials

\section{Risk of bias}

\begin{tabular}{|c|c|c|}
\hline Bias & Authors' judgement & Support for judgement \\
\hline $\begin{array}{l}\text { Random sequence genera- } \\
\text { tion (selection bias) }\end{array}$ & Unclear risk & Randomisation method not described \\
\hline $\begin{array}{l}\text { Allocation concealment } \\
\text { (selection bias) }\end{array}$ & Unclear risk & No details given \\
\hline $\begin{array}{l}\text { Blinding (performance } \\
\text { bias and detection bias) } \\
\text { All outcomes }\end{array}$ & High risk & Wait-list control (control group participants told treatment would be delayed) \\
\hline $\begin{array}{l}\text { Incomplete outcome data } \\
\text { (attrition bias) } \\
\text { All outcomes }\end{array}$ & Low risk & $<10 \%$ lost to follow-up, included in ITT analyses \\
\hline
\end{tabular}

Becona 2001b

\begin{tabular}{ll}
\hline Methods & $\begin{array}{l}\text { Setting: community, Spain } \\
\text { Recruitment: smokers interested in quitting within } 6 \text { months }\end{array}$ \\
\hline Participants & \begin{tabular}{l}
724 smokers, $42 \%$ female, average age 37, average cpd 26 \\
\hline Interventions
\end{tabular} \\
$\begin{array}{ll}\text { - Wait-list control (followed for only } 6 \text { months) } \\
\text { Self-help manual }\end{array}$ \\
\hline $\begin{array}{l}\text { Abstinence at } 12 \text { months (30-day point prevalence) or } 6 \text { months (7-day point prevalence) } \\
\text { Vatcomes }\end{array}$ \\
$\begin{array}{l}3 \text { plus } 2 \text { vs } 1 \text {, self-help vs control; } 6 \text { months' follow-up; excluded from meta-analysis of Comparison } 2 \\
\text { due to heterogeneity } \\
2 \text { vs } 3 \text { in Comparison between materials; not included in meta-analysis }\end{array}$
\end{tabular}

\section{Risk of bias}

\begin{tabular}{lll}
\hline Bias & Authors' judgement & Support for judgement \\
\hline $\begin{array}{l}\text { Random sequence genera- } \\
\text { tion (selection bias) }\end{array}$ & Unclear risk & Randomisation method not described \\
\hline $\begin{array}{l}\text { Allocation concealment } \\
\text { (selection bias) }\end{array}$ & Unclear risk & No details given \\
\hline $\begin{array}{l}\text { Blinding (performance } \\
\text { bias and detection bias) }\end{array}$ & High risk & Wait-list control \\
\end{tabular}


Becona 2001b (Continued)

All outcomes

\begin{tabular}{|c|c|c|}
\hline $\begin{array}{l}\text { Incomplete outcome data } \\
\text { (attrition bias) }\end{array}$ & Unclear risk & $\begin{array}{l}\text { All randomised participants included in ITT analysis, but number followed up } \\
\text { not reported }\end{array}$ \\
\hline
\end{tabular}

All outcomes

not reported

Berman 1995

\begin{tabular}{ll} 
Methods & $\begin{array}{l}\text { Setting: multi-ethnic community, USA } \\
\text { Recruitment: via schools; smokers interested in health screening and cessation }\end{array}$ \\
\hline Participants & 348 smokers, $51 \%$ female, average age 37 \\
\hline Interventions & $\begin{array}{l}\text { All participants received cardiovascular health screening and educational materials } \\
\text { - Freedom from Smoking for You and Your Family, or Spanish equivalent; minimally tailored message at } \\
\text { completion of } 3 \text { months' telephone follow-up and tailored letter (group class offered after } 6 \text { months' } \\
\text { follow-up) } \\
\text { - How to Double Your Quitting Power, or Spanish equivalent }\end{array}$ \\
\hline
\end{tabular}

\begin{tabular}{ll}
\hline Outcomes & $\begin{array}{l}\text { Abstinence at } 6 \text { months, continuous (other outcomes also reported, no differences in findings) } \\
\text { Validation: attempted unsuccessfully at } 12 \text { months }\end{array}$ \\
\hline Notes & $\begin{array}{l}\text { No non-self-help control, so does not contribute to main analysis; no differences at any time point and } \\
\text { no definition of 'abstinence' }\end{array}$ \\
\hline
\end{tabular}

\section{Risk of bias}

\begin{tabular}{|c|c|c|}
\hline Bias & Authors' judgement & Support for judgement \\
\hline $\begin{array}{l}\text { Random sequence genera- } \\
\text { tion (selection bias) }\end{array}$ & Low risk & Randomised by school using coin toss \\
\hline \multirow[t]{2}{*}{$\begin{array}{l}\text { Allocation concealment } \\
\text { (selection bias) }\end{array}$} & High risk & $\begin{array}{l}\text { Participants enrolled proactively after randomisation, so potential for selec- } \\
\text { tion bias }\end{array}$ \\
\hline & & Fewer participants in control (179) than experimental (267) conditions \\
\hline $\begin{array}{l}\text { Blinding (performance } \\
\text { bias and detection bias) } \\
\text { All outcomes }\end{array}$ & Low risk & $\begin{array}{l}\text { Biochemical validation attempted but very few participants provided samples; } \\
\text { however, interventions of similar intensity differed only by content, so differ- } \\
\text { ential misreport judged unlikely }\end{array}$ \\
\hline $\begin{array}{l}\text { Incomplete outcome data } \\
\text { (attrition bias) } \\
\text { All outcomes }\end{array}$ & Low risk & $218(62.6 \%)$ reached at 12 months' follow-up \\
\hline
\end{tabular}

\begin{tabular}{ll} 
Betson 1998 & $\begin{array}{l}\text { Setting: government outpatient clinic, Hong Kong } \\
\text { Recruitment: smokers aged }<65\end{array}$ \\
\hline Participants & 865 smokers, $92 \%$ male, $49 \%$ smoking $>10 \mathrm{cpd}$ \\
\hline Interventions & $\cdot$ No intervention \\
& $\cdot$ Self-help materials (Chinese translation of American Cancer Society booklet)
\end{tabular}


Betson 1998 (Continued)

- Physician advice (1 minute, based on 4 As)

- Physician advice and self-help booklet

\begin{tabular}{ll}
\hline Outcomes & Abstinence at 1 year (sustained from 3 months) \\
& Validation: poor response to request for urine specimen, so data based on self-report \\
\hline Notes & 2 vs 1 , self-help with face-to-face contact \\
& 4 vs 3, self-help as adjunct to advice \\
& Full paper provided by Professor Lam \\
\hline
\end{tabular}

\section{Risk of bias}

\begin{tabular}{|c|c|c|}
\hline Bias & Authors' judgement & Support for judgement \\
\hline $\begin{array}{l}\text { Random sequence genera- } \\
\text { tion (selection bias) }\end{array}$ & Unclear risk & $\begin{array}{l}\text { Table of random numbers used to allocate questionnaires to } 4 \text { groups placed } \\
\text { in sealed numbered envelopes }\end{array}$ \\
\hline \multirow{2}{*}{$\begin{array}{l}\text { Allocation concealment } \\
\text { (selection bias) }\end{array}$} & Unclear risk & "Every doctor was given a set of sealed envelopes" \\
\hline & & $\begin{array}{l}\text { Considerable imbalance in numbers in each group; unclear whether this was } \\
\text { due to randomisation procedure or selection bias }\end{array}$ \\
\hline $\begin{array}{l}\text { Blinding (performance } \\
\text { bias and detection bias) } \\
\text { All outcomes }\end{array}$ & Unclear risk & $\begin{array}{l}\text { Abstract only; unclear if participants were aware of what other arms received, } \\
\text { but within comparisons in this review, interventions varied by intensity }\end{array}$ \\
\hline $\begin{array}{l}\text { Incomplete outcome data } \\
\text { (attrition bias) } \\
\text { All outcomes }\end{array}$ & Low risk & $36 \%$ lost to follow-up, included in ITT analysis \\
\hline
\end{tabular}

Borland 2003

\begin{tabular}{ll}
\hline Methods & $\begin{array}{l}\text { Setting: Quitline, Australia } \\
\text { Recruitment: smokers seeking materials or counselling }\end{array}$ \\
\hline Participants & 1578 smokers, 1050 in relevant arms, $54 \%$ female, modal age 30 to 49 , average cpd 23 \\
\hline Interventions & - Standard self-help quit-pack based around SoC \\
& - Additional tailored letters at baseline, at 3 months, and at 6 months based on mailed assessments \\
- Additional proactive telephone counselling (not included in this review) & Some participants in all groups received brief reactive counselling before enrolment
\end{tabular}

\begin{tabular}{ll}
\hline Outcomes & $\begin{array}{l}\text { Abstinence at } 1 \text { year (sustained for } 9 \text { months) } \\
\text { Validation: none }\end{array}$ \\
\hline Notes & 2 vs 1, tailored self-help vs standard self-help \\
\hline
\end{tabular}

\section{Risk of bias}

\begin{tabular}{lll}
\hline Bias & Authors' judgement & Support for judgement \\
\hline $\begin{array}{l}\text { Random sequence genera- } \\
\text { tion (selection bias) }\end{array}$ & High risk & "Shuffling questionnaires" \\
\hline $\begin{array}{l}\text { Allocation concealment } \\
\text { (selection bias) }\end{array}$ & Unclear risk & $\begin{array}{l}\text { "no opportunity for interviewers to influence choice of condition", so bias } \\
\text { judged unlikely }\end{array}$ \\
\hline \hline
\end{tabular}


Borland 2003 (Continued)

Blinding (performance Low risk Self-reported outcomes from participants not blinded to treatment condition, bias and detection bias) but with no personal contact and similar levels of intensity, considered at low All outcomes risk for differential misreport

Incomplete outcome data Low risk

Follow-up $78.9 \%$ for $1 ; 76.9 \%$ for 2

(attrition bias)

All outcomes

Losses included in ITT analysis

Excluding losses would marginally lower effect size

Borland 2004

$\begin{array}{ll}\text { Methods } & \text { Setting: Quitline, Australia } \\ & \text { Recruitment: callers wanting written self-help materials }\end{array}$

\begin{tabular}{ll}
\hline Participants & $\begin{array}{l}772 \text { baseline smokers (baseline quitters not included in this review), } 54 \% \text { female (all participants), ap- } \\
\text { proximately } 47 \% \text { aged }<30 \text {, average cpd } 19\end{array}$
\end{tabular}

\begin{tabular}{ll}
\hline Interventions & - Standard self-help quit pack \\
& $\cdot$ Additional tailored letters, based on assessment phone calls; average number 5.7 (SD 4.6) \\
\hline Outcomes & $\begin{array}{l}\text { Abstinence at } 12 \text { months (sustained for } 6 \text { months) } \\
\text { Validation: none }\end{array}$ \\
\hline Notes & 2 vs 1 , tailored self-help vs standard self-help \\
& No control for effects of multiple contacts
\end{tabular}

\section{Risk of bias}

\begin{tabular}{|c|c|c|}
\hline Bias & Authors' judgement & Support for judgement \\
\hline $\begin{array}{l}\text { Random sequence genera- } \\
\text { tion (selection bias) }\end{array}$ & Low risk & Computer-generated ID numbers, even numbers allocated to intervention \\
\hline $\begin{array}{l}\text { Allocation concealment } \\
\text { (selection bias) }\end{array}$ & Low risk & ID number generated after agreement to participate obtained \\
\hline $\begin{array}{l}\text { Blinding (performance } \\
\text { bias and detection bias) } \\
\text { All outcomes }\end{array}$ & Low risk & $\begin{array}{l}\text { Blinding not possible because of the nature of the intervention, but "partici- } \\
\text { pants in each condition [did] not know about the other condition unless they } \\
\text { specifically asked ... (none did)" } \\
\text { No blinding or validation of smoking status, but because of low-contact nature } \\
\text { of intervention, differential misreport of smoking unlikely }\end{array}$ \\
\hline $\begin{array}{l}\text { Incomplete outcome data } \\
\text { (attrition bias) } \\
\text { All outcomes }\end{array}$ & Low risk & $\begin{array}{l}\text { Follow-up } 71.3 \% \% \text { for } 1 ; 63.8 \% \text { for } 2 \\
\text { Losses included in ITT analysis } \\
\text { Excluding losses would lower effect size }\end{array}$ \\
\hline
\end{tabular}

Brandon 2016

Methods Setting: USA, population-based


Recruitment: nationwide; smokers called a toll-free telephone number in response to advertisements in newspapers, radio, cable TV, public transit, and public service announcements

\begin{tabular}{ll}
\hline Participants & 1874 smokers who want to quit, $65.8 \%$ female, average age 47.5 , average cpd 20.5 \\
\hline Interventions & $\begin{array}{l}\text { - Standard repeated mailings (SRM): a revised version of the Forever Free booklets, sent at baseline, } \\
\text { and at } 1,2,3,5,7,9 \text {, and } 12 \text { months }\end{array}$ \\
$\cdot$ Intensive repeated mailings (IRM): same as above with 2 additional booklets (at 15 and 18 months) \\
and 9 brief pamphlets designed to enhance the perception of social support (sent every month without \\
a booklet) \\
$\cdot$ Traditional self-help (TSH) (control): single self-help booklet
\end{tabular}

Outcomes

Strictest: 7 -day point prevalence abstinence at 24 months

Other follow-ups: 6,12 , and 18 months

Validation: none

Notes $\quad$ Funding: "This work was supported by grant R01CA134347 from the National Cancer Institute. This work has also been supported in part by the Biostatistics and Survey Methods Core Facility at the H. Lee Moffitt Cancer Center and Research Institute, a National Cancer Institute-designated Comprehensive Cancer Center (P30CA76292)"

Declaration of interest: "Thomas Brandon has consulted for and received tobacco-related research support from Pfizer, Inc. The rights to the intervention materials used in this study are owned by Moffitt Cancer Center. In the event that future revenue derives from these products, Moffitt has a revenue-sharing plan with investigators. No other financial disclosures were reported by the authors of this paper"

\section{Risk of bias}

\begin{tabular}{lll}
\hline Bias & Authors' judgement & Support for judgement \\
\hline $\begin{array}{l}\text { Random sequence genera- } \\
\text { tion (selection bias) }\end{array}$ & Low risk & $\begin{array}{l}\text { Quote: "Individuals were allocated to the three intervention arms using simple } \\
\text { randomization without stratification. Intervention assignment was generated } \\
\text { by computer upon entry of screening data into a relational database" }\end{array}$ \\
\hline
\end{tabular}

Allocation concealment Low risk Not described, but no face-to-face participant contact with researchers
(selection bias)

\begin{tabular}{|c|c|c|}
\hline $\begin{array}{l}\text { Blinding (performance } \\
\text { bias and detection bias) } \\
\text { All outcomes }\end{array}$ & Unclear risk & $\begin{array}{l}\text { Not clear if participants were aware of other group assignments; no objective } \\
\text { outcome measure; however, study author states there is "evidence of little } \\
\text { benefit derived from inclusion of biochemical verification measures in low- } \\
\text { intensity interventions such as these that have no face-to-face contact, and } \\
\text { there is little incentive to falsely report abstinence" }\end{array}$ \\
\hline
\end{tabular}

\begin{tabular}{ll}
\hline $\begin{array}{l}\text { Incomplete outcome data } \\
\text { (attrition bias) }\end{array}$ & Low risk \\
All outcomes & $\begin{array}{l}\text { Dropout increases from the least to the most intensive intervention: } 38 \% \\
\text { (TSH), 41\% (SRM), and 43\% (IRM) }\end{array}$ \\
& However, no baseline differences and similar follow-up rates
\end{tabular}

$\begin{array}{ll}\text { Methods } & \text { Setting: hospital chest clinics and inpatient wards, UK } \\ \text { Recruitment: patients with smoking-related conditions }\end{array}$


BTS 1983 (Continued)

\begin{tabular}{ll} 
Participants & 748 smokers (in relevant arms), average age 49, average cpd 24 \\
\hline Interventions & - Brief advice to quit from a physician \\
- Advice and self-help booklet containing information and advice \\
- Same as second bullet here plus placebo chewing gum (not included in this review) \\
- Same as second bullet here plus nicotine gum (not included in this review)
\end{tabular}

\begin{tabular}{ll}
\hline Outcomes & $\begin{array}{l}\text { Sustained abstinence } 6 \text { to } 12 \text { months ( } 2 \text { months point prevalence) } \\
\text { Validation: venous carboxyhaemoglobin and thiocyanate }\end{array}$
\end{tabular}

\begin{tabular}{|c|c|c|}
\hline Notes & \multicolumn{2}{|c|}{2 vs 1 , self-help vs control. } \\
\hline \multicolumn{3}{|l|}{ Risk of bias } \\
\hline Bias & Authors' judgement & Support for judgement \\
\hline $\begin{array}{l}\text { Random sequence genera- } \\
\text { tion (selection bias) }\end{array}$ & Low risk & $\begin{array}{l}\text { Centrally generated; "each physician initially received a balanced block of } 12 \\
\text { treatments" }\end{array}$ \\
\hline $\begin{array}{l}\text { Allocation concealment } \\
\text { (selection bias) }\end{array}$ & Low risk & Numbered envelopes, opened after eligibility assessed \\
\hline $\begin{array}{l}\text { Blinding (performance } \\
\text { bias and detection bias) } \\
\text { All outcomes }\end{array}$ & Unclear risk & $\begin{array}{l}\text { Biochemical validation, but possible performance bias in that physicians } \\
\text { handing out leaflets were not blind to treatment condition and this may have } \\
\text { impacted advice; insufficient detail reported by which to judge }\end{array}$ \\
\hline $\begin{array}{l}\text { Incomplete outcome data } \\
\text { (attrition bias) } \\
\text { All outcomes }\end{array}$ & Low risk & 48 withdrawals re-included in this analysis with no impact on effect size \\
\hline
\end{tabular}

Burling 1989

\begin{tabular}{ll}
\hline Methods & $\begin{array}{l}\text { Setting: Veterans Administration Medical Center, USA } \\
\text { Recruitment: VA employees }\end{array}$ \\
\hline Participants & 58 smokers, average age 44, average cpd 27 \\
\hline Interventions & $\begin{array}{l}\text {. American Cancer Society and ALA pamphlets about smoking, a telephone hotline, and a stop-smok- } \\
\text { ing contest that gave vouchers for a draw, for each day with expired CO < } 8 \text { ppm } \\
\text { - As bullet above plus use of a computer to enter data on smoking behaviour and smoking a cigarette } \\
\text { through a filter attached to the computer; this produced an individualised nicotine fading programme } \\
\text { that was explained in an accompanying manual }\end{array}$
\end{tabular}

\begin{tabular}{|c|c|c|}
\hline Outcomes & \multicolumn{2}{|l|}{$\begin{array}{l}\text { Abstinence at } 6 \text { months } \\
\text { Validation: } \mathrm{CO}<8 \mathrm{ppm}\end{array}$} \\
\hline Notes & \multicolumn{2}{|c|}{2 vs 1 , tailored self-help vs standard self-help } \\
\hline \multicolumn{3}{|l|}{ Risk of bias } \\
\hline Bias & Authors' judgement & Support for judgement \\
\hline $\begin{array}{l}\text { Random sequence genera- } \\
\text { tion (selection bias) }\end{array}$ & Unclear risk & Randomised; method not described \\
\hline
\end{tabular}


Burling 1989 (Continued)

Allocation concealment $\quad$ Unclear risk $\quad$ No details given
(selection bias)

Blinding (performance Low risk

Interventions of similar intensity; biochemical validation

bias and detection bias)

All outcomes

Incomplete outcome data Low risk
(attrition bias)

(attrition bias)

All outcomes

\section{Campbell 1986}

\begin{tabular}{|c|c|c|}
\hline Methods & \multicolumn{2}{|c|}{$\begin{array}{l}\text { Setting: } 2 \text { chest clinics in Scotland, UK } \\
\text { Recruitment: smokers attending outpatient clinic (unselected) }\end{array}$} \\
\hline Participants & \multicolumn{2}{|c|}{1206 smokers referred for chest radiography, $44 \%$ aged $>50$} \\
\hline Interventions & \multicolumn{2}{|c|}{$\begin{array}{l}\text { - Self-help; } 13 \text {-page booklet } \\
\text { - No treatment control }\end{array}$} \\
\hline Outcomes & \multicolumn{2}{|c|}{$\begin{array}{l}\text { Abstinence at } 1 \text { year (self-report of no smoking for } 6 \text { months) } \\
\text { Validation: expired CO }<10 \text { ppm; non-attenders classified as smokers }\end{array}$} \\
\hline Notes & \multicolumn{2}{|c|}{ Face-to-face contact but no advice } \\
\hline \multicolumn{3}{|l|}{ Risk of bias } \\
\hline Bias & Authors' judgement & Support for judgement \\
\hline $\begin{array}{l}\text { Random sequence genera- } \\
\text { tion (selection bias) }\end{array}$ & High risk & Quasi-random (interventions alternated fortnightly) \\
\hline $\begin{array}{l}\text { Allocation concealment } \\
\text { (selection bias) }\end{array}$ & High risk & $\begin{array}{l}\text { All smoking patients attending were eligible, so potential for selection bias } \\
\text { probably low, but imbalance in age distribution between groups }\end{array}$ \\
\hline $\begin{array}{l}\text { Blinding (performance } \\
\text { bias and detection bias) } \\
\text { All outcomes }\end{array}$ & Low risk & $\begin{array}{l}\text { Control group unlikely to know what intervention group was receiving; same } \\
\text { amount of personal contact; biochemical validation used }\end{array}$ \\
\hline $\begin{array}{l}\text { Incomplete outcome data } \\
\text { (attrition bias) } \\
\text { All outcomes }\end{array}$ & Low risk & Follow-up $74.5 \%$ intervention, $74.1 \%$ control; losses included in ITT analysis \\
\hline
\end{tabular}

\section{Clark 2004}

\begin{tabular}{ll}
\hline Methods & $\begin{array}{l}\text { Setting: lung cancer screening centre, USA } \\
\text { Recruitment: smokers enrolled in a screening study } 1 \text { year previously }\end{array}$ \\
\hline Participants & 171 smokers, $21 \%$ in pre-contemplation, $29 \%$ female, average age $57,46 \%$ smoked 11 to $20 \mathrm{cpd}$ \\
\hline Interventions & $\cdot$ List of internet cessation resources; 10 sites with brief descriptions \\
$\cdot$ Self-help manuals Clearing the Air and Quit Smoking Action Plan
\end{tabular}


Clark 2004 (Continued)

\begin{tabular}{ll} 
Outcomes & $\begin{array}{l}\text { Abstinence at } 12 \text { months (7-day point prevalence) } \\
\text { Validation: } \mathrm{CO}\end{array}$ \\
\hline Notes & Comparison between self-help interventions; not in meta-analysis \\
& Study authors' hypothesis was that list of internet cessation resources would be superior (OR 0.44, 95\% \\
Cl 0.12 to 1.43$)$
\end{tabular}

\begin{tabular}{|c|c|c|}
\hline \multicolumn{3}{|l|}{ Risk of bias } \\
\hline Bias & Authors' judgement & Support for judgement \\
\hline $\begin{array}{l}\text { Random sequence genera- } \\
\text { tion (selection bias) }\end{array}$ & Unclear risk & Randomised; method not described \\
\hline $\begin{array}{l}\text { Allocation concealment } \\
\text { (selection bias) }\end{array}$ & Unclear risk & No details given \\
\hline $\begin{array}{l}\text { Blinding (performance } \\
\text { bias and detection bias) } \\
\text { All outcomes }\end{array}$ & Low risk & $\begin{array}{l}\text { Biochemical validation; interventions of similar intensity, so bias judged un- } \\
\text { likely }\end{array}$ \\
\hline $\begin{array}{l}\text { Incomplete outcome data } \\
\text { (attrition bias) } \\
\text { All outcomes }\end{array}$ & Unclear risk & Number lost to follow-up not reported but all included in ITT analysis \\
\hline
\end{tabular}

\section{Cuckle 1984}

$\begin{array}{ll}\text { Methods } & \text { Setting: community exposed to a 15-minute TV programme with offer of a smoking quit kit, UK } \\ \text { Recruitment: random sample of individuals requesting a kit }\end{array}$

\begin{tabular}{ll}
\hline Participants & $\begin{array}{l}4492 \text { smokers randomised; results based on } 2117 \text { (47\%) who replied to a baseline and a follow-up ques- } \\
\text { tionnaire }\end{array}$ \\
\hline Interventions & $\begin{array}{l}\text { Control - letter apologising for shortage of kits } \\
\cdot \text { Quit kit } \\
\cdot \text { Quit kit and additional materials } 6 \text { months later }\end{array}$ \\
\hline Outcomes & $\begin{array}{l}\text { Abstinence at } 12 \text { months } \\
\text { Saliva cotinine from } 66 \% \text { of quitters; quit rates corrected by the disconfirmation rate found for each } \\
\text { group }\end{array}$ \\
\hline Notes & 2 vs 1, self-help vs control \\
3 vs 2, additional materials
\end{tabular}

\section{Risk of bias}

\begin{tabular}{lll}
\hline Bias & Authors' judgement & Support for judgement \\
\hline $\begin{array}{l}\text { Random sequence genera- } \\
\text { tion (selection bias) }\end{array}$ & Unclear risk & "One-third were chosen at random as controls and did not receive a kit" \\
\hline $\begin{array}{l}\text { Allocation concealment } \\
\text { (selection bias) }\end{array}$ & Unclear risk & No details given, but no personal contact, so selection bias unlikely \\
\hline
\end{tabular}


Cuckle 1984 (Continued)

Blinding (performance High risk Control group would have expected to receive quit kit and then to be told bias and detection bias) there was a shortage so they did not get them; could introduce performance All outcomes bias

Incomplete outcome data High risk (attrition bias)

Low response rate in a population-based study, so only participants who All outcomes replied to baseline questionnaire and follow-up questionnaire were included Response rate to baseline questionnaire was $70 \%$ in control group compared to $39 \%$ for those receiving a kit

Cummings 1988

$\begin{array}{ll}\text { Methods } & \text { Setting; stop smoking hotline, USA } \\ \text { Recruitment: callers who accepted offer of a stop smoking booklet and who agreed to follow up }\end{array}$

\begin{tabular}{ll}
\hline Participants & 1895 smokers, $65 \%$ female, average age 42 , average cpd $28,89 \%$ had made at least 1 prior quit attempt \\
\hline Interventions & First 4 groups received booklets of similar length ( \pm 50 pages) and format, differing in precise instruc- \\
tions & \\
& $\cdot$ High structure (day-by-day plan) recommending 'cold turkey' quitting \\
& $\cdot$ High structure recommending gradual reduction \\
& $\cdot$ Low structure (menu of exercises) with gradual reduction \\
& - Low structure, 'cold turkey' \\
& Control booklet: 15 pages stressing health effects of smoking
\end{tabular}

Outcomes Abstinence from 1 month to 6 months; self-report by telephone interview with blinded assessors No biochemical validation; confirmation by a significant other

\begin{tabular}{|c|c|c|}
\hline Notes & \multicolumn{2}{|c|}{1 to 4 vs 5 in main analysis } \\
\hline \multicolumn{3}{|l|}{ Risk of bias } \\
\hline Bias & Authors' judgement & Support for judgement \\
\hline $\begin{array}{l}\text { Random sequence genera- } \\
\text { tion (selection bias) }\end{array}$ & Unclear risk & Randomised; method not described \\
\hline $\begin{array}{l}\text { Allocation concealment } \\
\text { (selection bias) }\end{array}$ & Unclear risk & No details given \\
\hline $\begin{array}{l}\text { Blinding (performance } \\
\text { bias and detection bias) } \\
\text { All outcomes }\end{array}$ & Low risk & $\begin{array}{l}\text { Confirmation by significant other; booklets of similar length, so differential } \\
\text { misreport unlikely }\end{array}$ \\
\hline $\begin{array}{l}\text { Incomplete outcome data } \\
\text { (attrition bias) } \\
\text { All outcomes }\end{array}$ & Low risk & $\begin{array}{l}\text { Analyses based on participants reached at } 1 \text { month and } 6 \text { months' follow-up; } \\
89 \% \text { of those randomised } \\
\text { Dropout rates similar in all groups }\end{array}$ \\
\hline
\end{tabular}

Curry 1991

$\begin{array}{ll}\text { Methods } & \text { Setting: HMO, USA } \\ \text { Recruitment: advertisement for study in HMO magazine }\end{array}$


Curry 1991 (Continued)

\begin{tabular}{ll} 
Participants & 1217 smokers, average age 44, average cpd 25 \\
\hline Interventions & Factorial design \\
& $\cdot$ Self-help programme, Breaking Away \\
& Self-help and up to 3 sets of personalised feedback based on baseline questionnaire and progress re- \\
ports (intrinsic motivation) & $\cdot$ Self-help and incentives including a prize draw for returning progress reports (extrinsic motivation) \\
& $\cdot$ Self-help and intrinsic and extrinsic motivation
\end{tabular}

\begin{tabular}{ll}
\hline Outcomes & $\begin{array}{l}\text { Sustained abstinence at } 12 \text { months ( } 7 \text { days at } 3 \text { months and } 12 \text { months) } \\
\text { Validation: saliva cotinine } \leq 10 \mathrm{ng} / \mathrm{mL} \text { at } 12 \text { months for abstainers in locality; correcting for disconfir- } \\
\text { mation rates did not affect sustained abstinence numbers }\end{array}$ \\
\hline Notes & 4 and 2 vs 3 and 1 for effect of personalised feedback (tailoring) \\
& Extrinsic motivation did not increase quit rates \\
& Aim was to increase use of materials
\end{tabular}

\section{Risk of bias}

\begin{tabular}{lll}
\hline Bias & Authors' judgement & Support for judgement \\
\hline $\begin{array}{l}\text { Random sequence genera- } \\
\text { tion (selection bias) }\end{array}$ & Unclear risk & Randomised; stratified by gender and cpd; no other information \\
\hline $\begin{array}{l}\text { Allocation concealment } \\
\text { (selection bias) }\end{array}$ & Unclear risk & No details given \\
\hline $\begin{array}{l}\text { Blinding (performance } \\
\text { bias and detection bias) } \\
\text { All outcomes }\end{array}$ & Unclear risk & $\begin{array}{l}\text { Unclear if control group participants knew the nature of intervention condi- } \\
\text { tions; biochemical validation }\end{array}$ \\
\hline $\begin{array}{l}\text { Incomplete outcome data } \\
\text { (attrition bias) } \\
\text { All outcomes }\end{array}$ & Unclear risk & $\begin{array}{l}\text { No information on number lost; all randomised participants included in ITT } \\
\text { analysis }\end{array}$ \\
\hline
\end{tabular}

\section{Curry 1995}

\begin{tabular}{|c|c|}
\hline Methods & $\begin{array}{l}\text { Setting: HMO, USA } \\
\text { Recruitment: smokers identified via a telephone survey of health behaviour in a random sample of } \\
\text { HMO members (unselected) }\end{array}$ \\
\hline Participants & 1137 smokers, 53\% female, average age 41 , average cpd 17 \\
\hline Interventions & $\begin{array}{l}\text { No face-to-face contact } \\
\text { - Control - no materials } \\
\text { - Self-help booklet (Breaking Away) with units to complete, relevant to all stages of readiness to quit } \\
\text { - As second bullet above plus feedback based on computer analysis of initial survey; included a hand- } \\
\text { written form and a list of relevant parts of booklet } \\
\text { - As third bullet above plus up to } 3 \text { counsellor-initiated phone calls (not included in this review) }\end{array}$ \\
\hline
\end{tabular}

\begin{tabular}{ll}
\hline Outcomes & Sustained abstinence 3 months to 12 months \\
& Validation: saliva cotinine requested but not obtained for all participants; disconfirmation rates not \\
& significantly different between groups
\end{tabular}


Curry 1995 (Continued)

Notes
12 months' rather than 21 months' follow-up used for comparability with other studies; study author confirmed numbers quit

2 vs 1 in self-help vs control

3 vs 2 in effects of tailoring

\section{Risk of bias}

\section{Bias}

Random sequence genera- Unclear risk

tion (selection bias)

\begin{tabular}{ll}
\hline $\begin{array}{l}\text { Allocation concealment } \\
\text { (selection bias) }\end{array}$ & Unclear risk details given
\end{tabular}

Blinding (performance $\quad$ High risk
bias and detection bias)

bias and detection bias)

All outcomes
Control group aware that they may be receiving materials or phone calls,
which they did not receive; this could introduce performance bias

"Collecting saliva cotinine...was challenging because participants had neither explicitly volunteered for a study of smoking behavior nor requested treatment for smoking cessation... nearly one fourth of those contacted refused to provide a sample"

Higher disconfirmation in control group but difference not significant

Incomplete outcome data Low risk $88 \%$ provided data at 3 months and at 12 months

(attrition bias)

All outcomes

No difference in response rates across groups

Missing counted as smoking in meta-analysis

Davies 1992

\begin{tabular}{|c|c|}
\hline Methods & $\begin{array}{l}\text { Setting: community, Ottawa, Canada } \\
\text { Recruitment: each of } 156 \text { nursing students recruited } 2 \text { non-hospitalised smokers (selected) }\end{array}$ \\
\hline Participants & 307 smokers, average age 36 , average cpd 20 \\
\hline Interventions & $\begin{array}{l}\text { - List of community resources, delivered during a home visit by a nursing student } \\
\text { - Time to Quit (TTQ) self-help booklet plus list of community resources, delivered by a nursing student } \\
\text { after training in the TTQ programme }\end{array}$ \\
\hline Outcomes & $\begin{array}{l}\text { Abstinence at } 9 \text { months } \\
\text { Validation: saliva cotinine }<100 \mathrm{ng} / \mathrm{mL}\end{array}$ \\
\hline Notes & $\begin{array}{l}\text { It is unclear what advice was given to the control group } \\
\text { Marginal to include because self-help was confounded by student training, but does not affect meta- } \\
\text { analysis }\end{array}$ \\
\hline
\end{tabular}

\section{Risk of bias}

\begin{tabular}{lll}
\hline Bias & Authors' judgement & Support for judgement \\
\hline $\begin{array}{l}\text { Random sequence genera- } \\
\text { tion (selection bias) }\end{array}$ & Unclear risk & Randomised; method not described \\
\hline \hline
\end{tabular}

Print-based self-help interventions for smoking cessation (Review) 
Davies 1992 (Continued)

Allocation concealment $\quad$ Unclear risk
(selection bias)

Blinding (performance

bias and detection bias)

All outcomes

Incomplete outcome data Low risk

(attrition bias)

High risk

Nurses knew who would receive more training after delivering control condition and before meeting with intervention participants, introducing likelihood of performance bias

Participants lost to follow-up re-included as smokers for meta-analysis; $28 \%$ lost to follow-up; similar across groups

All outcomes

\section{Davis 1984}

\begin{tabular}{ll}
\hline Methods & $\begin{array}{l}\text { Setting: local communities with lung associations, USA } \\
\text { Recruitment: media advertisements for American Lung Association (ALA) self-help materials }\end{array}$ \\
\hline Participants & 1237 smokers who completed a questionnaire and paid a refundable deposit \\
\hline Interventions & No face-to-face contact \\
& - ALA leaflets (8 leaflets including 2 brief cessation brochures: Me Quit Smoking? Why? and Me Quit \\
& Smoking? How?) \\
& - Ceaflets and maintenance manual: A Lifetime of Freedom from Smoking \\
& - Cessation and maintenance manuals
\end{tabular}

\begin{tabular}{ll}
\hline Outcomes & $\begin{array}{l}\text { Sustained abstinence at } 12 \text { months (point prevalence at all } 5 \text { follow-up points); self-report in a tele- } \\
\text { phone interview } \\
\text { Validation: none }\end{array}$ \\
\hline Notes & 2 plus 3 plus 4 vs 1, self-help vs leaflet only
\end{tabular}

\section{Risk of bias}

\begin{tabular}{lll}
\hline Bias & Authors' judgement & Support for judgement \\
\hline $\begin{array}{l}\text { Random sequence genera- } \\
\text { tion (selection bias) }\end{array}$ & Unclear risk & Randomised; method not described \\
\hline $\begin{array}{l}\text { Allocation concealment } \\
\text { (selection bias) }\end{array}$ & Unclear risk & No details given \\
\hline $\begin{array}{l}\text { Blinding (performance } \\
\text { bias and detection bias) } \\
\text { All outcomes }\end{array}$ & Low risk & $\begin{array}{l}\text { No biochemical validation used but no personal contact; interventions all of } \\
\text { similar intensity, so differential misreport judged unlikely }\end{array}$ \\
\hline $\begin{array}{l}\text { Incomplete outcome data } \\
\text { (attrition bias) }\end{array}$ & Unclear risk & $\begin{array}{l}\text { No information on number lost; all randomised participants included in ITT } \\
\text { All outcomes }\end{array}$ \\
\hline
\end{tabular}

Davis 1992

$\begin{array}{ll}\text { Methods } & \text { Setting: community, USA } \\ & \text { Recruitment: advertisements for the Cancer Information Service hotline }\end{array}$


Davis 1992 (Continued)

Participants Women smokers with children under 6 calling hotline; results based on 630 of 873 (72\%) of those recruited who were followed up at 6 months

Interventions

- Quitting Times, a self-help guide developed to meet the special needs of women smokers with young children (65 pages in magazine format)

- ALA: Freedom from Smoking for You and Your Family

- National Cancer Institute: Clearing the Air

Outcomes Abstinence at 6 months (7-day point prevalence)

Validation: no biochemical validation; confirmation by surrogate; those refusing to give a surrogate were classified as smokers

\section{Notes}

Does not contribute to main analysis, 1 vs 2 and 3 ; impact of targeting to population

All 3 guides covered similar topics; no significant differences were found between any of them

\section{Risk of bias}

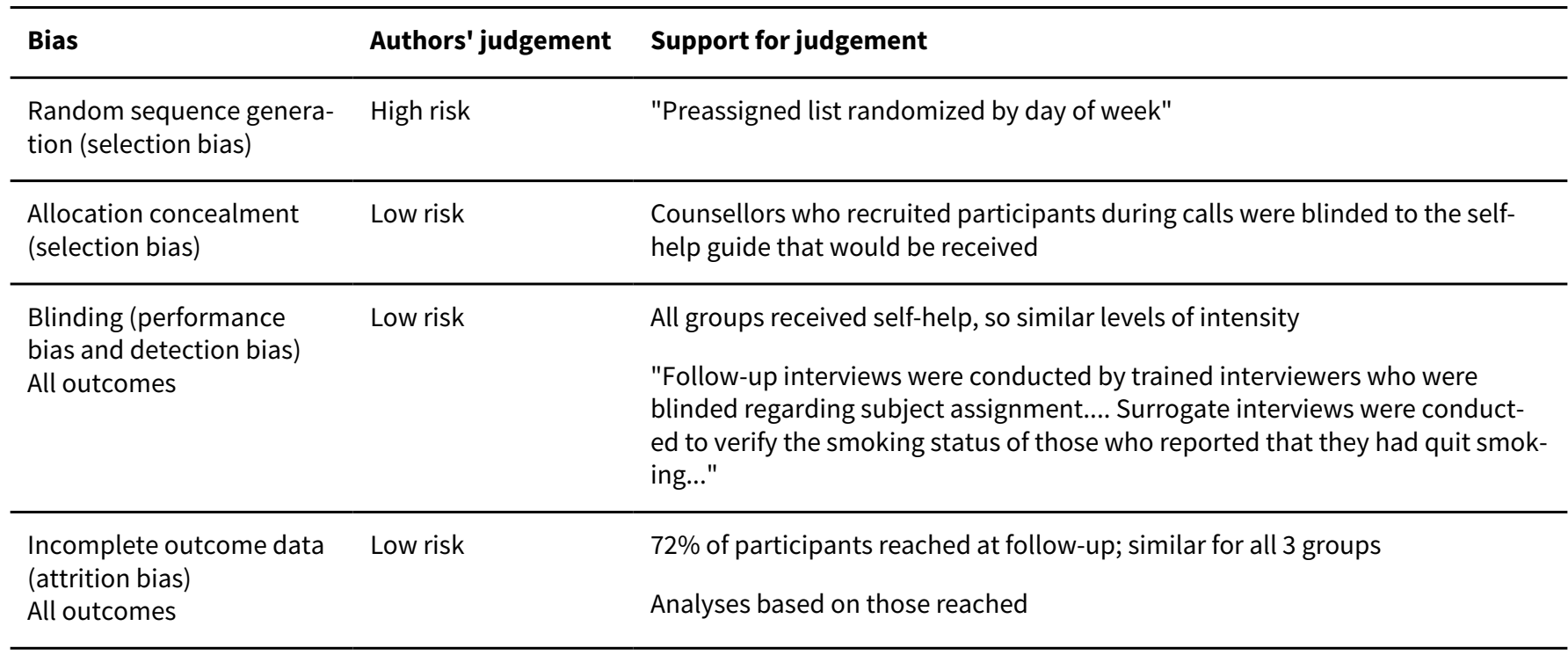

\section{de Vries 2008}

$\begin{array}{ll}\text { Methods } & \text { Setting: community, Netherlands } \\ & \text { Recruitment: telephone recruitment for a multiple risk factor health promotion intervention }\end{array}$

Participants 156 smokers amongst 2827 participants, of whom $1331(47 \%)$ responded at T4

Baseline all participants: 55\% female, average age 49

\begin{tabular}{ll}
\hline Interventions & $\begin{array}{l}\text { - Printed tailored letters on smoking as an identified risk factor (other targets were physical activity, } \\
\text { nutrition); half of the group had action planning component in third letter } \\
\text { - Printed generic letters }\end{array}$ \\
\hline Outcomes & $\begin{array}{l}\text { Abstinence at } 9 \text { months (not defined) } \\
\text { Validation: none }\end{array}$ \\
\hline Notes & Effect of tailoring \\
& Numbers of smokers at baseline and numbers of quitters provided by study author
\end{tabular}


de Vries 2008 (Continued)

Risk of bias

\begin{tabular}{lll}
\hline Bias & Authors' judgement & Support for judgement \\
\hline $\begin{array}{l}\text { Random sequence genera- } \\
\text { tion (selection bias) }\end{array}$ & Unclear risk & Randomised; method not described \\
\hline $\begin{array}{l}\text { Allocation concealment } \\
\text { (selection bias) }\end{array}$ & Unclear risk & Details not given \\
\hline $\begin{array}{l}\text { Blinding (performance } \\
\text { bias and detection bias) }\end{array}$ & Low risk & No biochemical validation but interventions of similar intensity; differential \\
All outcomes & misreport judged to be unlikely \\
\hline $\begin{array}{l}\text { Incomplete outcome data } \\
\text { (attrition bias) }\end{array}$ & High risk & Only baseline smokers who responded to follow-up survey included in analysis \\
All outcomes & & \\
\hline
\end{tabular}

Dijkstra 1998a

\begin{tabular}{|c|c|}
\hline Methods & $\begin{array}{l}\text { Setting: community, Netherlands } \\
\text { Recruitment: newspaper adverts; not selected by level of motivation to quit }\end{array}$ \\
\hline Participants & 1546 smokers, 59\% female, average age 40, average cpd 20.3 \\
\hline Interventions & $\begin{array}{l}\text { No face-to-face contact } \\
\text { - Letter with information on positive outcomes of quitting }(\mathrm{OC}) \\
\text { - Letter with information on skills for quitting (SE) } \\
\text { - Letter with outcomes and skills information (BO) } \\
\text { All letters computer-generated reports of } 4 \text { to } 7 \text { pages, personalised and tailored from baseline ques- } \\
\text { tionnaire } \\
\cdot \text { - No information }(\mathrm{CO})\end{array}$ \\
\hline
\end{tabular}

\begin{tabular}{ll}
\hline Outcomes & 12-month sustained abstinence at 14 months; self-report by postal questionnaire \\
Validation: none; participants told that a sample would be tested for CO levels
\end{tabular}

$\begin{array}{ll}\text { Notes } & 1 \text { and } 2 \text { and } 3 \text { vs } 4 \text { in tailored materials since } 2014 \text { (previously in main comparison) } \\ & \text { Results sensitive to the outcome used; no difference in point prevalences }\end{array}$

\section{Risk of bias}

\begin{tabular}{lll}
\hline Bias & Authors' judgement & Support for judgement \\
\hline $\begin{array}{l}\text { Random sequence genera- } \\
\text { tion (selection bias) }\end{array}$ & Unclear risk & Randomised; method not described \\
\hline $\begin{array}{l}\text { Allocation concealment } \\
\text { (selection bias) }\end{array}$ & Unclear risk & No details given \\
\hline $\begin{array}{l}\text { Blinding (performance } \\
\text { bias and detection bias) }\end{array}$ & High risk & $\begin{array}{l}\text { No biochemical validation used; control group knew other participants receiv- } \\
\text { ill outcomes an intervention }\end{array}$ \\
\hline $\begin{array}{l}\text { Incomplete outcome data } \\
\text { (attrition bias) }\end{array}$ & Low risk & $64 \%$ responded at 14 months; no differences across groups \\
All outcomes & &
\end{tabular}




\section{Dijkstra 1999}

Setting: community, Netherlands
Recruitment: newspaper adverts for smokers not planning to quit in the next 6 months (unmotivated
volunteers)

\section{volunteers)}

\begin{tabular}{|c|c|c|}
\hline Participants & \multicolumn{2}{|c|}{843 smokers not planning to quit, $63 \%$ female, average age 42 , average cpd 22} \\
\hline Interventions & \multicolumn{2}{|c|}{$\begin{array}{l}\text { No face-to-face contact } \\
\text { - Three tailored letters (MT) } \\
\text { - Single tailored letter (ST) } \\
\text { - Self-help manual, } 48 \text { pages colour (SHG) } \\
\text { - No intervention (CO) }\end{array}$} \\
\hline Outcomes & \multicolumn{2}{|c|}{$\begin{array}{l}\text { Abstinence at } 6 \text { months (7-day point prevalence), self-report by postal questionnaire } \\
\text { Validation: none } \\
\text { Primary outcomes for trial: SoC; intention to quit }\end{array}$} \\
\hline Notes & \multicolumn{2}{|c|}{$\begin{array}{l}3 \text { vs } 4 \text { in self-help vs control } \\
1 \text { and } 2 \text { vs } 3 \text { in effects of tailoring }\end{array}$} \\
\hline \multicolumn{3}{|l|}{ Risk of bias } \\
\hline Bias & Authors' judgement & Support for judgement \\
\hline $\begin{array}{l}\text { Random sequence genera- } \\
\text { tion (selection bias) }\end{array}$ & Unclear risk & Randomised; method not described \\
\hline $\begin{array}{l}\text { Allocation concealment } \\
\text { (selection bias) }\end{array}$ & Unclear risk & No details given \\
\hline $\begin{array}{l}\text { Blinding (performance } \\
\text { bias and detection bias) } \\
\text { All outcomes }\end{array}$ & Unclear risk & $\begin{array}{l}\text { Unclear if control group knew intervention arms receiving additional informa- } \\
\text { tion; no biochemical validation }\end{array}$ \\
\hline $\begin{array}{l}\text { Incomplete outcome data } \\
\text { (attrition bias) } \\
\text { All outcomes }\end{array}$ & Low risk & $\begin{array}{l}89 \% \text { responded at } 6 \text { months } \\
\text { Attrition predicted by years smoking and group } \\
\text { Denominator used in meta-analysis includes all randomised }\end{array}$ \\
\hline
\end{tabular}

Etter 2004

\begin{tabular}{ll}
\hline Methods & $\begin{array}{l}\text { Setting: community, Switzerland } \\
\text { Recruitment: mailing to population registers (not selected) }\end{array}$ \\
\hline Participants & $\begin{array}{l}2934 \text { smokers aged } 15+, 74 \% \text { pre-contemplators, } 40 \% \text { tried to quit in previous year, } 51 \% \text { female, aver- } \\
\text { age age } 36, \text { average cpd } 20\end{array}$ \\
\hline
\end{tabular}


Etter 2004 (Continued)

Interventions $\quad$ - Tailored 8-page letter plus SoC-matched booklets; at 2 months, 4 months, 12 months - repeat ques-

tionnaire to initiate further letter

- No intervention

$\begin{array}{ll}\text { Outcomes } & \text { Abstinence at } 24 \text { months (in maintenance stage; quit for }>6 \text { months), } 4 \text { weeks; 7-day abstinence also re- } \\ \text { ported } \\ \text { Validation: none }\end{array}$

Notes Tailored self-help vs nothing; approximately half of group 1 received 1 letter only

Effects at 6 months (Etter Arch Int Med 2001) not sustained at 24 months

Relative difference smaller if shorter-term abstinence used

\section{Risk of bias}

\begin{tabular}{lll}
\hline Bias & Authors' judgement & Support for judgement \\
\hline $\begin{array}{l}\text { Random sequence genera- } \\
\text { tion (selection bias) }\end{array}$ & Low risk & Randomisation: "list of random numbers" \\
\hline $\begin{array}{l}\text { Allocation concealment } \\
\text { (selection bias) }\end{array}$ & Unclear risk & No details given \\
\hline $\begin{array}{l}\text { Blinding (performance } \\
\text { bias and detection bias) } \\
\text { All outcomes }\end{array}$ & High risk & "...members of the control group received a letter indicating that they had \\
\hline $\begin{array}{l}\text { Incomplete outcome data } \\
\text { (attrition bias) } \\
\text { All outcomes }\end{array}$ & Low risk & \begin{tabular}{l} 
No validation; intervention intensity higher than for control group \\
\hline
\end{tabular} \\
\hline
\end{tabular}

Fraser 2014

\begin{tabular}{|c|c|}
\hline Methods & $\begin{array}{l}\text { Setting: USA, population-based } \\
\text { Recruitment: smokers who entered a website for smokers (smokefree.gov) recruited through their } \\
\text { computers }\end{array}$ \\
\hline Participants & $\begin{array}{l}1034 \text { people who smoked and were seeking help to quit, } 68 \% \text { female, average age } 39.3 \text {, average cpd } \\
19.3\end{array}$ \\
\hline Interventions & $\begin{array}{l}\text { Study comprised } 32 \text { arms testing combinations of 'on' and 'off' versions of } 5 \text { interventions: the National } \\
\text { Cancer Institute website vs a 'lite' website, telephone counselling vs no counselling, a self-help manu- } \\
\text { al vs a brief brochure, motivational email messages vs no messages, and nicotine replacement therapy } \\
\text { (NRT) vs no NRT }\end{array}$ \\
\hline Outcomes & $\begin{array}{l}\text { Smoking abstinence: } 7 \text {-day point-prevalence at } 7 \text { months } \\
\text { Validation: none; self-report only }\end{array}$ \\
\hline Notes & $\begin{array}{l}\text { Funding: the project was funded through a contract to our university from Matthews Media Group, un- } \\
\text { derwritten by ARRA funding to the National Cancer Institute. Additional funding was provided by the } \\
\text { National Cancer Institute (5K05CA139871) }\end{array}$ \\
\hline
\end{tabular}




\section{Risk of bias}

\begin{tabular}{lll}
\hline Bias & Authors' judgement & Support for judgement \\
\hline $\begin{array}{l}\text { Random sequence genera- } \\
\text { tion (selection bias) }\end{array}$ & Unclear risk & Method of randomisation not described \\
\hline $\begin{array}{l}\text { Allocation concealment } \\
\text { (selection bias) }\end{array}$ & Low risk & $\begin{array}{l}\text { Quote: "Randomization occurred immediately after the confirmation call, and } \\
\text { participants completing this step were sent an automated email welcoming } \\
\text { them to the study" }\end{array}$ \\
\hline $\begin{array}{l}\text { Blinding (performance } \\
\text { bias and detection bias) }\end{array}$ & High risk & $\begin{array}{l}\text { Quote: "Follow-up interviewers were blind as to treatment assignment"; how- } \\
\text { ever, "participants [...] were sent an automated email [...] outlining services } \\
\text { they would receive"; no biochemical validation of self-reported abstinence } \\
\text { used }\end{array}$ \\
\hline $\begin{array}{l}\text { Incomplete outcome data } \\
\text { (attrition bias) }\end{array}$ & Low risk & Quote: "Range of response rates across the 5 treatment factors = 76-81\%" \\
\begin{tabular}{l} 
All outcomes \\
\hline
\end{tabular} & & \\
\hline
\end{tabular}

Gilbert 2013

\begin{tabular}{ll} 
Methods & Setting: general practices, UK \\
& Recruitment: identified via GP records; mailed proactively \\
\hline Participants & $\begin{array}{l}6697 \text { current smokers aged } 18 \text { to } 65 \text { years, } 56 \% \text { female, average age } 45, \text { average cpd } 18 \text { (excluding } 5.4 \% \\
\text { non-daily smokers) } \\
47 \% \text { not planning to quit within } 6 \text { months }\end{array}$
\end{tabular}

Interventions

- Standard, non-tailored NHS: Stop Smoking Start Living booklet and computer tailored advice; report based on information obtained through baseline assessment questionnaire, letter from GP; follow-up assessment via mail at 1 month; additional tailored mailing

- Standard, non-tailored NHS: Stop Smoking Start Living booklet

Outcomes 3 months' sustained abstinence at 6 months

\section{Validation: none}

Notes 214 participants excluded post randomisation for valid reasons

\section{Risk of bias}

\begin{tabular}{lll}
\hline Bias & Authors' judgement & Support for judgement \\
\hline $\begin{array}{l}\text { Random sequence genera- } \\
\text { tion (selection bias) }\end{array}$ & Low risk & $\begin{array}{l}\text { "Blocked randomisation codes were generated externally and given to an in- } \\
\text { dependent administrator in sealed envelopes upon receipt of completed ques- } \\
\text { tionnaires" }\end{array}$ \\
\hline $\begin{array}{l}\text { Allocation concealment } \\
\text { (selection bias) }\end{array}$ & Low risk & $\begin{array}{l}\text { "Participants were accepted into the study before knowledge of the next as- } \\
\text { signment in the sequence in order to minimise selection bias. Each study par- }\end{array}$
\end{tabular}


ticipant randomised received the treatment corresponding to the next free study number in the randomised sequence"

Blinding (performance High risk
bias and detection bias)

All outcomes No biochemical validation; participants aware of what other condition was re-
ceiving

"Participants were told that they would be sent some information about quitting, and could be randomly selected to receive additional information based on their answers in the questionnaire"

\section{Incomplete outcome data Low risk} (attrition bias)

$27 \%$ lost intervention, $24 \%$ lost control; no significant differences in predictors of dropouts between groups

All outcomes

Study authors conducted sensitivity analyses with alternative assumptions about dropouts

\begin{tabular}{ll} 
Glasgow 1981 & $\begin{array}{l}\text { Setting: community, USA } \\
\text { Recruitment: } \text { media advertisements }\end{array}$ \\
\hline Participants & 88 smokers (40 in self-help conditions) \\
\hline Interventions & $\begin{array}{l}\text { Factorial trial of } 3 \text { different self-help materials, with or without additional group support } \\
\cdot \text { Danaher \& Lichtenstein manual } \\
\cdot \text { Pomerleau \& Pomerleau manual } \\
\cdot \text { / Quit Kit }\end{array}$ \\
\hline Outcomes & $\begin{array}{l}\text { Abstinence at } 6 \text { months } \\
\text { Validation: CO < 15 ppm }\end{array}$ \\
\hline Notes & $\begin{array}{l}\text { 3 different self-help conditions and no strong hypothesis about direction of treatment difference be- } \\
\text { tween the Danaher \& Lichtenstein manual and the Pomerleau \& Pomerleau manual, so not used in the } \\
\text { meta-analysis of different programmes }\end{array}$ \\
No statistical differences between quit rates (also included in group therapy review)
\end{tabular}

\section{Risk of bias}

\begin{tabular}{lll}
\hline Bias & Authors' judgement & Support for judgement \\
\hline $\begin{array}{l}\text { Random sequence genera- } \\
\text { tion (selection bias) }\end{array}$ & Unclear risk & "Randomly assigned"; method not described \\
\hline $\begin{array}{l}\text { Allocation concealment } \\
\text { (selection bias) }\end{array}$ & Unclear risk & No details given \\
\hline $\begin{array}{l}\text { Blinding (performance } \\
\text { bias and detection bias) } \\
\text { All outcomes }\end{array}$ & Low risk & $\begin{array}{l}\text { Biochemical validation used; all groups received materials (differences in con- } \\
\text { tent only) }\end{array}$ \\
\hline $\begin{array}{l}\text { Incomplete outcome data } \\
\text { (attrition bias) } \\
\begin{array}{l}\text { All outcomes } \\
\hline\end{array}\end{array}$ & Low risk & $3 / 88$ lost to follow-up; group not specified, so not included as smokers \\
\hline
\end{tabular}


Gritz 1992

\begin{tabular}{|c|c|c|}
\hline Methods & \multicolumn{2}{|c|}{$\begin{array}{l}\text { Setting: HMO, USA } \\
\text { Recruitment: members of HMO agreeing to participate in a Preventive Health Behaviour study and } \\
\text { completing a baseline survey (unselected - not informed that study was focussed on smoking) }\end{array}$} \\
\hline Participants & \multicolumn{2}{|c|}{1396 female smokers, average age $38,42 \%$ smoked 15 to $24 \mathrm{cpd}$} \\
\hline Interventions & \multicolumn{2}{|c|}{$\begin{array}{l}\text { No face-to-face contact; } 5 \text { follow-up interviews in } 2 \text { years } \\
\text { - Self-help programme mailed in } 6 \text { weekly instalments; manuals tailored to the concerns of female } \\
\text { smokers and addressing weight gain, social support, stress, and coping mechanisms } \\
\text { - Control - no materials; same schedule of follow-up phone calls }\end{array}$} \\
\hline Outcomes & \multicolumn{2}{|c|}{$\begin{array}{l}\text { Sustained abstinence at } 1 \text { month, } 6 \text { months, } 12 \text { months, and } 18 \text { months } \\
\text { Validation: saliva cotinine }<15 \mathrm{ng} / \mathrm{mL} \text {, but due to low success in obtaining samples, unadjusted rates } \\
\text { used. No difference in disconfirmation rates between intervention and control groups }\end{array}$} \\
\hline Notes & \multicolumn{2}{|c|}{$\begin{array}{l}\text { The strictest measure of abstinence extracted gives the lowest } P \text { value for the difference between } \\
\text { groups; all other measures show a smaller difference in quit rates }\end{array}$} \\
\hline \multicolumn{3}{|l|}{ Risk of bias } \\
\hline Bias & Authors' judgement & Support for judgement \\
\hline $\begin{array}{l}\text { Random sequence genera- } \\
\text { tion (selection bias) }\end{array}$ & Unclear risk & Randomised; method not described \\
\hline $\begin{array}{l}\text { Allocation concealment } \\
\text { (selection bias) }\end{array}$ & Unclear risk & No details given \\
\hline $\begin{array}{l}\text { Blinding (performance } \\
\text { bias and detection bias) } \\
\text { All outcomes }\end{array}$ & Low risk & $\begin{array}{l}\text { Control group participants not aware of the nature of the intervention; partici- } \\
\text { pants did not know study was aimed at smoking cessation Biochemical valida- } \\
\text { tion conducted; not used due to low success in obtaining samples, but no dif- } \\
\text { ference in disconfirmation between groups, suggesting differential misreport } \\
\text { unlikely }\end{array}$ \\
\hline
\end{tabular}

\begin{tabular}{|c|c|c|}
\hline \multirow{3}{*}{$\begin{array}{l}\text { Incomplete outcome data } \\
\text { (attrition bias) } \\
\text { All outcomes }\end{array}$} & Low risk & $12.7 \%$ lost to follow-up at 18 months \\
\hline & & $\begin{array}{l}\text { Number in each group at baseline not stated, so losses not included as smok- } \\
\text { ers in meta-analysis }\end{array}$ \\
\hline & & Similar losses across groups, so no effect on estimate \\
\hline
\end{tabular}

Harackiewicz 1988

\begin{tabular}{|c|c|}
\hline Methods & $\begin{array}{l}\text { Setting: university campus health centre/medical centre, USA } \\
\text { Recruitment: smokers applying for free cessation programme }\end{array}$ \\
\hline Participants & 98 smokers in relevant arms, $61 \%$ female, average age 35 , average $\mathrm{cpd} 27$ for all participants \\
\hline Interventions & $\begin{array}{l}\text { All received advice from a doctor or nurse to quit by using the written materials, which were different } \\
\text { for each group } \\
\text { - Self-help manual employing intrinsic motivation approach (Stopping Smoking on Your Own with } \\
\text { Nicorette) and nicotine gum } \\
\text { - Self-help manual employing extrinsic motivation approach (The Doctor's Program for Stopping Smok- } \\
\text { ing with Nicorette) and nicotine gum } \\
\text { - Intrinsic motivation self-help manual only }\end{array}$ \\
\hline
\end{tabular}


Harackiewicz 1988 (Continued)

- Control - short booklet only, with no motivational element

\begin{tabular}{ll}
\hline Outcomes & $\begin{array}{l}\text { Sustained abstinence at } 12 \text { months ( } 3 \text { months to } 12 \text { months) } \\
\text { Validation } \mathrm{CO}<8 \mathrm{ppm} \text { at each visit; saliva thiocyanate }<10 \mathrm{mg} / \mathrm{dL} \text { at } 3 \text { months and } 6 \text { months; } 2 \text { partici- } \\
\text { pants reclassified as smokers }\end{array}$ \\
\hline Notes & 3 vs 4 for self-help compared to control \\
& 1 and 2 not used
\end{tabular}

\section{Risk of bias}

\begin{tabular}{lll}
\hline Bias & Authors' judgement & Support for judgement \\
\hline $\begin{array}{l}\text { Random sequence genera- } \\
\text { tion (selection bias) }\end{array}$ & Unclear risk & "Randomly assigned"; method not described \\
\hline $\begin{array}{l}\text { Allocation concealment } \\
\text { (selection bias) }\end{array}$ & Unclear risk & No details given \\
\hline $\begin{array}{l}\text { Blinding (performance } \\
\text { bias and detection bias) } \\
\text { All outcomes }\end{array}$ & Low risk & $\begin{array}{l}\text { Biochemical validation; groups differed in intervention contact but not in in- } \\
\text { tensity }\end{array}$ \\
\hline $\begin{array}{l}\text { Incomplete outcome data } \\
\begin{array}{l}\text { (attrition bias) } \\
\text { All outcomes }\end{array}\end{array}$ & Low risk & $\begin{array}{l}\text { 22 of } 197 \text { participants did not attend any follow-up and were excluded from } \\
\text { analyses }\end{array}$ \\
& & "drop-out rates did not differ according to condition" \\
& & Other losses assumed to be smoking \\
\hline
\end{tabular}

Hollis 1993

\begin{tabular}{ll}
\hline Methods & Setting: HMO, USA \\
& Recruitment: smokers visiting primary care physicians (unselected)
\end{tabular}

\section{Participants}

2707 smokers (1383 in relevant arms) who received provider advice, average age 40, average cpd 18

\begin{tabular}{ll}
\hline Outcomes & $\begin{array}{l}\text { Abstinence at } 12 \text { months (3 months' and } 12 \text { months' point prevalence) } \\
\text { Validation: saliva cotinine; participants not providing samples counted as smokers }\end{array}$ \\
\hline Notes & 1 vs 4, comparison of self-help vs control \\
\hline Risk of bias & Authors' judgement Support for judgement \\
\hline Bias &
\end{tabular}


Hollis 1993 (Continued)

$\begin{array}{ll}\begin{array}{l}\text { Random sequence genera- } \\ \text { tion (selection bias) }\end{array} & \text { High risk } \\ & \begin{array}{l}\text { Pseudo-randomisation (2 random digits in health record number) of smokers } \\ \text { tion }\end{array}\end{array}$

\begin{tabular}{lll}
\hline $\begin{array}{l}\text { Allocation concealment } \\
\text { (selection bias) }\end{array}$ & High risk & $\begin{array}{l}\text { Allocation not concealed but no evidence of selection bias; baseline character- } \\
\text { istics similar }\end{array}$ \\
\hline $\begin{array}{l}\text { Blinding (performance } \\
\text { bias and detection bias) } \\
\text { All outcomes }\end{array}$ & Unclear risk & $\begin{array}{l}\text { Unclear if participants knew the nature of what other groups were receiving; } \\
\text { biochemical validation; } 55 \% \text { of reported quitters provided saliva sample; no } \\
\text { differences by group }\end{array}$ \\
\hline
\end{tabular}

\begin{tabular}{ll}
\hline Incomplete outcome data & Low risk \\
(attrition bias) & $\begin{array}{l}14 \% \text { lost to follow-up at } 12 \text { months; response rates not significantly different } \\
\text { across treatment groups; all participants included in analysis }\end{array}$
\end{tabular}

(attrition bias)
All outcomes

$14 \%$ lost to follow-up at 12 months; response rates not significantly different
across treatment groups; all participants included in analysis

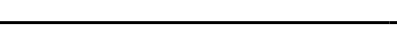

Hoving 2010

\begin{tabular}{ll}
\hline Methods & Setting: community, Netherlands \\
& $\begin{array}{l}\text { Recruitment: } 75 \text { general practices (passive recruitment via questionnaire in waiting room), } 65 \text { pharma- } \\
\text { cies (15 passive, } 50 \text { active recruitment) }\end{array}$ \\
\hline Participants & $\begin{array}{l}1019 \text { smokers (545 pharmacy, } 474 \mathrm{GP}) \text {; motivated to quit within } 6 \text { months; smoked in last } 7 \text { days before } \\
\text { baseline assessment } \\
56 \% \text { female, average age 45, average cpd } 22\end{array}$ \\
\hline Interventions & All participants completed baseline questionnaire \\
- Mailed 5- to 7-page tailored letter, using same tailoring as Dijkstra 1998a (based on I-change model) \\
$\cdot$ Thank you letter only
\end{tabular}

Outcomes

Continuous abstinence from baseline at 3 months and at 12 months in pharmacy group, at 6 months in GP group

Validation: none

\section{Notes}

\section{Risk of bias}

\begin{tabular}{lll}
\hline Bias & Authors' judgement & Support for judgement \\
\hline $\begin{array}{l}\text { Random sequence genera- } \\
\text { tion (selection bias) }\end{array}$ & High risk & $\begin{array}{l}\text { "Randomised based on the colour coding on their questionnaire (blue for ex- } \\
\text { perimental group, yellow for control group)" }\end{array}$ \\
\hline $\begin{array}{l}\text { Allocation concealment } \\
\text { (selection bias) }\end{array}$ & High risk & $\begin{array}{l}\text { Allocation would not be concealed if anyone was aware of the significance of } \\
\text { colour }\end{array}$ \\
\hline $\begin{array}{l}\text { Blinding (performance } \\
\text { bias and detection bias) } \\
\text { All outcomes }\end{array}$ & Unclear risk & Not specified \\
\hline
\end{tabular}

\begin{tabular}{|c|c|c|}
\hline $\begin{array}{l}\text { Incomplete outcome data } \\
\text { (attrition bias) }\end{array}$ & Unclear risk & $\begin{array}{l}\text { Only experimental losses to follow-up reported ( } 63 / 256 \text { pharmacy, } 42 / 220 \mathrm{GP} \text { ); } \\
\text { unclear how many participants in the control group were lost }\end{array}$ \\
\hline
\end{tabular}


Hoving 2010 (Continued)

All outcomes

Humerfelt 1998

\begin{tabular}{|c|c|}
\hline Methods & $\begin{array}{l}\text { Setting: community, Norway } \\
\text { Recruitment: from participants in a community survey of men aged } 30 \text { to } 45 \text { years who had increased } \\
\text { risk of obstructive lung disease or lung cancer }\end{array}$ \\
\hline Participants & $\begin{array}{l}2610 \text { men who smoked with reduced } \mathrm{FEV}_{1} \text { and/or occupational asbestos exposure, average age } 37 \text {, av- } \\
\text { erage cpd } 16\end{array}$ \\
\hline Interventions & $\begin{array}{l}\text { - Mailed self-help pamphlet ( } 15 \text { pages), emphasising behavioural modification techniques in smoking } \\
\text { cessation and recommending an early quit date, accompanied by a letter from a respiratory physician } \\
\text { advising of high risk status established by the survey } \\
\text { - No intervention }\end{array}$ \\
\hline Outcomes & $\begin{array}{l}\text { Abstinence at } 15 \text { months (point prevalence) } \\
\text { Validation: participants in } 1 \text { geographical area invited for } \mathrm{CO} \text { measurement }(\mathrm{CO}<10 \mathrm{ppm})\end{array}$ \\
\hline \multirow[t]{3}{*}{ Notes } & $\begin{array}{l}\text { For meta-analysis, the number of quitters has been adjusted for the validated rate found in the sample } \\
\text { tested }(63 \% \text { in intervention } / 67 \% \text { in control) }\end{array}$ \\
\hline & Participants who stopped smoking before receiving materials were included \\
\hline & $\begin{array}{l}\text { Study authors give } 12 \text { months' sustained abstinence rates of } 5.6 \% \text { vs } 3.5 \% \text {, but these rates are based on } \\
\text { self-report by responders }\end{array}$ \\
\hline
\end{tabular}

\section{Risk of bias}

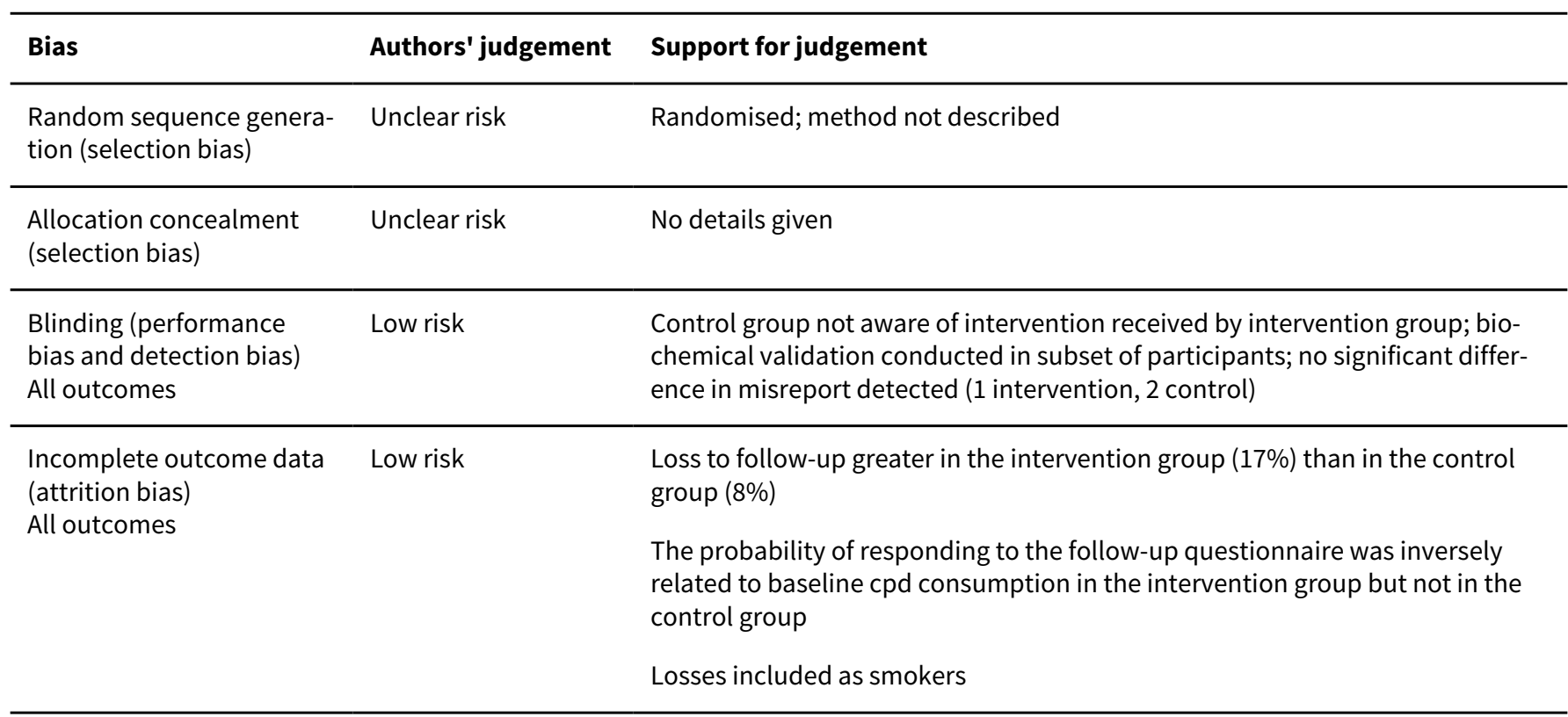

$\begin{array}{ll}\text { Methods } & \text { Setting: primary care, UK } \\ & \text { Recruitment: patients registered with practice invited to join }\end{array}$


ICRF 1994 (Continued)

\begin{tabular}{ll} 
Participants & 1686 smokers (over $15 \mathrm{cpd})$ \\
\hline Interventions & $2 \times 2$ factorial design \\
$\cdot$ Nicotine patch and $16-$ page Health Education Authority (HEA) pamphlet \\
$\cdot$ Placebo patch and HEA pamphlet \\
- Nicotine patch and 46-page booklet with more detailed information on cessation with the use of \\
patches \\
All participants seen once by a doctor and 4 times by a nurse
\end{tabular}

\begin{tabular}{ll}
\hline Outcomes & $\begin{array}{l}\text { Sustained abstinence at } 12 \text { months } \\
\text { Validation: salivary cotinine or expired CO }\end{array}$ \\
\hline Notes & Comparison between different self-help materials \\
& Not used in meta-analysis \\
& No clinically or statistically significant differences between materials in either patch condition \\
\hline
\end{tabular}

\section{Risk of bias}

\begin{tabular}{lll}
\hline Bias & Authors' judgement & Support for judgement \\
\hline $\begin{array}{l}\text { Random sequence genera- } \\
\text { tion (selection bias) }\end{array}$ & Low risk & Random allocation of study numbers to intervention groups \\
\hline $\begin{array}{l}\text { Allocation concealment } \\
\text { (selection bias) }\end{array}$ & Low risk & Sequential allocation of study numbers and pre-coded packages \\
\hline $\begin{array}{l}\text { Blinding (performance } \\
\text { bias and detection bias) } \\
\text { All outcomes }\end{array}$ & Low risk & Biochemical validation; similar levels of intensity across interventions \\
\hline $\begin{array}{l}\text { Incomplete outcome data } \\
\text { (attrition bias) } \\
\begin{array}{l}\text { All outcomes } \\
\end{array}\end{array}$ & Low risk & $\begin{array}{l}\text { Only early abstainers were followed up at } 6 \text { months and 12 months; 9.2\% lost } \\
\text { to follow-up at 12 weeks } \\
\text { All losses included as smokers }\end{array}$ \\
\hline
\end{tabular}

\section{Janz 1987}

\begin{tabular}{ll}
\hline Methods & $\begin{array}{l}\text { Setting: } 2 \text { outpatient medical clinics, USA } \\
\text { Recruitment: all smokers attending and giving informed consent for a study of health practices (unse- } \\
\text { lected) }\end{array}$ \\
\hline Participants & 250 smokers, average age 46, average cpd 24 \\
\hline Interventions & - Control - no intervention; clinic physicians not aware of the study (not included in the review) \\
& - Advice from the physician and brief consultation with a nurse \\
\hline
\end{tabular}

Outcomes

Abstinence at 6 months (ascertainment by telephone by independent interviewer)

Validation: none

Notes

3 vs 2 for effect of self-help as adjunct to advice

Graphed percentages based on numbers followed up 


\section{Risk of bias}

\section{Bias}

\section{Authors' judgement Support for judgement}

Random sequence genera- High risk tion (selection bias)
Pseudo-random assignment of half-day clinic sessions to experiment or control (control does not contribute to this review)

Within experiment clinics, participants randomised to manual or no manual condition; method not described

\begin{tabular}{|c|c|c|}
\hline $\begin{array}{l}\text { Allocation concealment } \\
\text { (selection bias) }\end{array}$ & Unclear risk & No details given \\
\hline $\begin{array}{l}\text { Blinding (performance } \\
\text { bias and detection bias) } \\
\text { All outcomes }\end{array}$ & Low risk & $\begin{array}{l}\text { No biochemical validation but interventions tested in this review included } \\
\text { same amount of face-to-face contact and self-report collection procedures de- } \\
\text { signed to minimise misreport (research personnel made clear they had no re- } \\
\text { lationship to healthcare team and responses were confidential) }\end{array}$ \\
\hline $\begin{array}{l}\text { Incomplete outcome data } \\
\text { (attrition bias) } \\
\text { All outcomes }\end{array}$ & Low risk & $\begin{array}{l}39(16 \%) \text { lost to follow-up at } 6 \text { months } \\
\text { "Drop-out rates did not vary significantly across study groups" } \\
\text { Losses not given by group, so not included in meta-analysis }\end{array}$ \\
\hline
\end{tabular}

Killen 1997

\begin{tabular}{|c|c|c|}
\hline Methods & \multicolumn{2}{|c|}{$\begin{array}{l}\text { Setting: community, USA } \\
\text { Recruitment: advertisements }\end{array}$} \\
\hline Participants & \multicolumn{2}{|c|}{424 smokers, $50 \%$ female, average age 42 to 47 years, average cpd 24} \\
\hline Interventions & \multicolumn{2}{|c|}{$\begin{array}{l}2 \times 2 \text { factorial design. All participants received self-help materials designed to help develop self-control } \\
\text { skills } \\
\text { - Self-help and placebo patch } \\
\text { - Self-help and nicotine patch }(21 \mathrm{mg}) \\
\text { - As first bullet above and video, watched during initial office visit, and for use at home } \\
\text { - As second bullet above and video }\end{array}$} \\
\hline Outcomes & \multicolumn{2}{|c|}{$\begin{array}{l}\text { Sustained abstinence ( } 6 \text { months and } 12 \text { months) } \\
\text { Validation: saliva cotinine }<20 \mathrm{ng} / \mathrm{mL}\end{array}$} \\
\hline Notes & \multicolumn{2}{|c|}{$\begin{array}{l}\text { Test of additional materials } \\
\text { With evidence of an interaction between nicotine and video conditions, nicotine arms entered sepa- } \\
\text { rately via a dummy study }\end{array}$} \\
\hline \multicolumn{3}{|l|}{ Risk of bias } \\
\hline Bias & Authors' judgement & Support for judgement \\
\hline $\begin{array}{l}\text { Random sequence genera- } \\
\text { tion (selection bias) }\end{array}$ & Unclear risk & Randomised in a $2 \times 2$ fully crossed factorial design; method not described \\
\hline $\begin{array}{l}\text { Allocation concealment } \\
\text { (selection bias) }\end{array}$ & Unclear risk & No details given \\
\hline
\end{tabular}


Killen 1997 (Continued)
Blinding (performance
Unclear risk
Unclear if participants not receiving video knew other participants were re- bias and detection bias) ceiving it (and viewing it in a group); biochemical validation used

All outcomes

\begin{tabular}{|c|c|c|}
\hline $\begin{array}{l}\text { Incomplete outcome data } \\
\text { (attrition bias) }\end{array}$ & Unclear risk & $\begin{array}{l}\text { Number lost to follow-up not specified, but all participants included in denom- } \\
\text { inators }\end{array}$ \\
\hline
\end{tabular}

(attrition bias)

inators

Killen $1997+$ NP

Methods Dummy study to enter results of Killen 1997 arms with nicotine patch

\section{Participants}

Interventions

\section{Outcomes}

\section{Notes}

\section{Kottke 1989}

$\begin{array}{ll}\text { Methods } & \text { Setting: family practices, USA } \\ \text { Recruitment: physicians recruited for trial; target population - all patients seen during the month (un- } \\ \text { selected) }\end{array}$

\begin{tabular}{ll}
\hline Participants & $\begin{array}{l}6 \text { physicians, } 1653 \text { smoking patients, "2/3rds female, average age slightly over } 40 \text { years, just under one } \\
\text { pack/day" }\end{array}$
\end{tabular}

\begin{tabular}{|c|c|c|}
\hline Interventions & \multicolumn{2}{|c|}{$\begin{array}{l}\text { Physicians attended 6-hour workshop } \\
\text { - Physicians attended workshop and given copies of Quit and Win for their patients } \\
\text { - Physicians received no support, but were asked to advise patients during the study period }\end{array}$} \\
\hline Outcomes & \multicolumn{2}{|c|}{$\begin{array}{l}\text { Abstinence at } 1 \text { year } \\
\text { Validation: serum cotinine }\end{array}$} \\
\hline Notes & \multicolumn{2}{|c|}{$\begin{array}{l}2 \text { vs } 1 \text {, effect of self-help in addition to advice from a trained physician } \\
\text { Including } 3 \text { in control group does not affect results (RR for trial becomes } 1.02 \text { rather than 0.99) }\end{array}$} \\
\hline \multicolumn{3}{|l|}{ Risk of bias } \\
\hline Bias & Authors' judgement & Support for judgement \\
\hline $\begin{array}{l}\text { Random sequence genera- } \\
\text { tion (selection bias) }\end{array}$ & High risk & $\begin{array}{l}\text { Cluster-randomised by physician - not by smoker; method not described; po- } \\
\text { tential for imbalance in participant characteristics, but number of participants } \\
\text { per physician low }\end{array}$ \\
\hline $\begin{array}{l}\text { Allocation concealment } \\
\text { (selection bias) }\end{array}$ & High risk & $\begin{array}{l}\text { Researchers attempted to contact all participants seen by physicians during } 1 \\
\text { month }\end{array}$ \\
\hline
\end{tabular}


Kottke 1989 (Continued)
Blinding (performance
Low risk
Biochemical validation used, as with cluster-randomisation by physician, bias and detection bias) seems unlikely that control group participants would know what other partici- All outcomes pants were offered

Incomplete outcome data Low risk
(attrition bias)

Over $87 \%$ of smokers identified at baseline were reached at 1 year - similar (attrition bias) across groups

All outcomes

\section{Lando 1988}

\begin{tabular}{ll}
\hline Methods & $\begin{array}{l}\text { Setting: family practice or pulmonary specialists, USA } \\
\text { Recruitment: physicians' patients wishing to use nicotine gum as a cessation aid }\end{array}$ \\
\hline Participants & 304 smokers, $62 \%$ female, average age 42, average cpd 31 \\
\hline Interventions & $\begin{array}{l}\cdot \text { Nicotine gum (NG) and experimental self-help materials emphasising behavioural strategies, as well } \\
\text { as correct use of gum } \\
\cdot \text { NG and control pamphlet Danger: The Facts About Smoking (American Cancer Society) }\end{array}$
\end{tabular}

\begin{tabular}{ll}
\hline Outcomes & $\begin{array}{l}\text { Abstinence at } 12 \text { months } \\
\text { Validation: proportion asked to provide saliva for thiocyanate: } 5 \text { discrepant - } 2 \text { self-help, } 3 \text { control - } \\
\text { but not clear if these were at } 6 \text { months or } 12 \text { months, so self-reported outcomes used }\end{array}$ \\
\hline Notes & $\begin{array}{l}\text { In main comparison with advice and leaflet for control, and in comparison of NG plus self-help vs NG } \\
\text { alone }\end{array}$
\end{tabular}

\section{Risk of bias}

\begin{tabular}{lll}
\hline Bias & Authors' judgement & Support for judgement \\
\hline $\begin{array}{l}\text { Random sequence genera- } \\
\text { tion (selection bias) }\end{array}$ & Unclear risk & Randomised; method not described \\
\hline $\begin{array}{l}\text { Allocation concealment } \\
\text { (selection bias) }\end{array}$ & Unclear risk & No details given \\
\hline $\begin{array}{l}\text { Blinding (performance } \\
\text { bias and detection bias) } \\
\text { All outcomes }\end{array}$ & Low risk & $\begin{array}{l}\text { Biochemical validation conducted but not used, but similar levels of intensity } \\
\text { and physicians blind to pamphlet condition, so differential misreport judged } \\
\text { to be unlikely }\end{array}$ \\
\hline $\begin{array}{l}\text { Incomplete outcome data } \\
\text { (attrition bias) } \\
\text { All outcomes }\end{array}$ & Unclear risk & No mention of number lost to follow-up \\
\hline
\end{tabular}

\section{Lando 1991}

\begin{tabular}{ll}
\hline Methods & Setting: community cardiovascular risk factor screening programme, USA \\
& Recruitment: smokers identified from screening programme who agreed to take part
\end{tabular}

\begin{tabular}{ll}
\hline Participants & 570 smokers, approx 50\% female, average age 42, average cpd 20 \\
\hline Interventions & $\begin{array}{l}\text { No face-to-face contact } \\
\text { Self-help Quit for Good materials (NCI) }\end{array}$
\end{tabular}


Lando 1991 (Continued)

- Self-help Quit and Win materials - a more extensive and structured programme

- Wait-list control

\begin{tabular}{ll}
\hline Outcomes & $\begin{array}{l}\text { Abstinence } 7 \text { months after randomisation (but only } 3 \text { to } 4 \text { months after receipt of materials) } \\
\text { Validation: none }\end{array}$
\end{tabular}

Validation: none

Notes Items in first and second bullets above treated as self-help programmes; no difference in results between them

Both intervention and control participants likely to have been exposed to simultaneous community Quit and Win contests

Study author notes that a number of participants quit between randomisation and receipt of materials

\section{Risk of bias}

\begin{tabular}{lll}
\hline Bias & Authors' judgement & Support for judgement \\
\hline $\begin{array}{l}\text { Random sequence genera- } \\
\text { tion (selection bias) }\end{array}$ & Unclear risk & Randomised; method not described \\
\hline $\begin{array}{l}\text { Allocation concealment } \\
\text { (selection bias) }\end{array}$ & Unclear risk & $\begin{array}{l}\text { No details given; significant differences between intervention and control for } \\
\text { sex and education; higher confidence in quitting among controls }\end{array}$ \\
\hline $\begin{array}{l}\text { Blinding (performance } \\
\text { bias and detection bias) } \\
\text { All outcomes }\end{array}$ & High risk & Wait-list control \\
\hline $\begin{array}{l}\text { Incomplete outcome data } \\
\text { (attrition bias) } \\
\text { All outcomes }\end{array}$ & Low risk & 25 lost to follow-up, of whom 13 were in control groups \\
\hline
\end{tabular}

Ledwith 1984

\begin{tabular}{ll} 
Methods & $\begin{array}{l}\text { Setting: community, Scotland, UK } \\
\text { Recruitment: newspaper advertisements for a smoker's advice centre }\end{array}$ \\
\hline Participants & 1839 smokers responding to offers of advice on stopping smoking \\
\hline Interventions & $\begin{array}{l}\text { No face-to-face contact } \\
\cdot \text { No advice control } \\
\text { - Self-help leaflet with standard letter } \\
\text { - Self-help leaflet and offer of individual advice upon returning a questionnaire }\end{array}$ \\
\hline Outcomes & $\begin{array}{l}\text { Abstinence at } 12 \text { months (for } 10 \text { months or longer - based on self-report) } \\
\text { Validation: attempt to obtain saliva for thiocyanate but not complete; data based on self-report only }\end{array}$ \\
\hline Notes & 2 vs 1, self-help \\
& 3 vs 2, effect of tailored advice \\
Only $34 \%$ returned baseline questionnaire to initiate tailored component \\
No information about contents of leaflet \\
Borderline whether this counts as a structured self-help programme
\end{tabular}

\section{Risk of bias}

Print-based self-help interventions for smoking cessation (Review) 
Ledwith 1984 (Continued)

\begin{tabular}{lll} 
Bias & Authors' judgement & Support for judgement \\
\hline $\begin{array}{l}\text { Random sequence genera- } \\
\text { tion (selection bias) }\end{array}$ & Unclear risk & "Assigned at random"; method not described \\
\hline $\begin{array}{l}\text { Allocation concealment } \\
\text { (selection bias) }\end{array}$ & Unclear risk & No details given \\
\hline $\begin{array}{l}\text { Blinding (performance } \\
\text { bias and detection bias) } \\
\text { All outcomes }\end{array}$ & Low risk & $\begin{array}{l}\text { Although attempts to get biochemical validation were unsuccessful, control } \\
\text { group was unaware of other treatment assignments; no face-to-face contact } \\
\text { was given, hence differential misreport was judged to be unlikely }\end{array}$ \\
\hline $\begin{array}{l}\text { Incomplete outcome data } \\
\text { (attrition bias) } \\
\text { All outcomes }\end{array}$ & Unclear risk & $\begin{array}{l}16 \% \text { lost to follow-up } \\
\text { Non-respondents included as smokers }\end{array}$
\end{tabular}

Lennox 2001

\begin{tabular}{ll} 
Methods & $\begin{array}{l}\text { Setting: general practice, Scotland, UK } \\
\text { Recruitment: smokers in general practices who returned questionnaires }\end{array}$ \\
\hline Participants & 2610 smokers; no demographic details \\
\hline Interventions & $\begin{array}{l}\text { No face-to-face contact } \\
\text { - Tailored letter from physician (4 pages) - based on SoC; decisional balance and other indicators from } \\
\text { questionnaire } \\
\text { - Untailored letter from physician (same format) - included specific behavioural advice on quitting } \\
\text { - Control - letter acknowledging questionnaire }\end{array}$
\end{tabular}

\begin{tabular}{ll}
\hline Outcomes & $\begin{array}{l}\text { Abstinence at } 12 \text { months (24 months' data reported but point prevalence, so does not represent a more } \\
\text { conservative measure) } \\
\text { Validation: saliva cotinine }\end{array}$ \\
\hline Notes & 2 vs 3, self-help, no contact \\
& 1 vs 2, tailoring
\end{tabular}

\section{Risk of bias}

\begin{tabular}{lll}
\hline Bias & Authors' judgement & Support for judgement \\
\hline $\begin{array}{l}\text { Random sequence genera- } \\
\text { tion (selection bias) }\end{array}$ & Low risk & Computer-generated random numbers \\
\hline $\begin{array}{l}\text { Allocation concealment } \\
\text { (selection bias) }\end{array}$ & Low risk & $\begin{array}{l}\text { "After the questionnaires were returned, we randomised the participants to } \\
\text { the groups" }\end{array}$ \\
\hline $\begin{array}{l}\text { Blinding (performance } \\
\text { bias and detection bias) } \\
\text { All outcomes }\end{array}$ & Low risk & $\begin{array}{l}\text { No participant contact; low risk of selection bias } \\
\text { tion used }\end{array}$ \\
\hline $\begin{array}{l}\text { Incomplete outcome data } \\
\text { (attrition bias) }\end{array}$ & Low risk & $\begin{array}{l}\text { 22\% loss to follow-up; similar across groups; non-responders counted as } \\
\text { sll outcomes }\end{array}$ \\
\hline \hline
\end{tabular}


Lichtenstein 2000

$\begin{array}{ll}\text { Methods } & \text { Setting: community, USA } \\ & \text { Recruitment: via electric utility mailing to identify households with smokers and low radon concen- } \\ & \text { trations }\end{array}$

\begin{tabular}{ll}
\hline Participants & 1006 smokers in 714 households, average cpd 20 \\
\hline Interventions & No face-to-face contact \\
& Standard Environmental Protection Agency leaflet on risks of radon \\
& Pamphlet highlighting risk of smoking in low concentrations of radon, with tips for quitting, or not \\
smoking indoors & Second bullet above plus up to 2 brief proactive telephone calls. \\
& All groups received standard letter with radon results
\end{tabular}

\begin{tabular}{ll}
\hline Outcomes & $\begin{array}{l}\text { Abstinence at } 12 \text { months, sustained at } 3 \text { months and } 12 \text { months } \\
\text { Validation: none }\end{array}$ \\
\hline Notes & 2 vs 1, self-help vs other control \\
& 3 contributes to telephone counselling review (Stead 2013b) \\
& Cluster-randomisation; $54 \%$ of smokers lived with another smoker \\
& Intraclass correlation for sustained abstinence was .010; analyses did not correct for this
\end{tabular}

\section{Risk of bias}

\begin{tabular}{lll}
\hline Bias & Authors' judgement & Support for judgement \\
\hline $\begin{array}{l}\text { Random sequence genera- } \\
\text { tion (selection bias) }\end{array}$ & Unclear risk & Randomised by household; method not described \\
\hline $\begin{array}{l}\text { Allocation concealment } \\
\text { (selection bias) }\end{array}$ & Unclear risk & No details given \\
\hline $\begin{array}{l}\text { Blinding (performance } \\
\text { bias and detection bias) } \\
\text { All outcomes }\end{array}$ & Low risk & $\begin{array}{l}\text { Self-reported outcomes from participants not blinded to treatment condition, } \\
\text { but the arms included in this analysis had similar levels of intensity with no } \\
\text { personal contact, so differential misreport judged unlikely }\end{array}$ \\
\hline $\begin{array}{l}\text { Incomplete outcome data } \\
\text { (attrition bias) } \\
\text { All outcomes }\end{array}$ & Low risk & $\begin{array}{l}\text { 80\% of households reached at 3 months and 12 months; no difference across } \\
\text { conditions }\end{array}$ \\
\hline
\end{tabular}

Lichtenstein 2008

\begin{tabular}{ll}
\hline Methods & $\begin{array}{l}\text { Setting: community, USA } \\
\text { Recruitment: via electric utility mailing with offer of radon test kit to identify households with smok- } \\
\text { ers }\end{array}$ \\
\hline Participants & 1364 households with 1821 smokers, $\sim 18 \mathrm{cpd}$ \\
\hline Interventions & $\begin{array}{l}\text { Factorial design crossing } \pm \text { brief phone counselling with video self-help materials } \\
\text { All households given } A \text { Citizen's Guide to Radon and a letter tailored to results of radon level test } \\
\cdot \text { Video (15 minutes) explaining risk of smoking and radon combination, encouraging quitting and/or } \\
\text { household smoking bans }\end{array}$ \\
\hline
\end{tabular}


Lichtenstein 2008 (Continued)

- No video

Outcomes Abstinence at 12 months, sustained at 3 months and 12 months

Validation: none

Notes Analyses accounting for clustering of multiple smokers in households reported to yield results generally consistent with simple analyses

We were unable to obtain data for arms with and without phone counselling, so the collapsed data contribute to comparisons 1.1 .2 and 2.1.2

\section{Risk of bias}

\begin{tabular}{lll}
\hline Bias & Authors' judgement & Support for judgement \\
\hline $\begin{array}{l}\text { Random sequence genera- } \\
\text { tion (selection bias) }\end{array}$ & High risk & $\begin{array}{l}\text { Responding households sequentially randomised to } 4 \text { conditions subject to } \\
\text { stratification on radon test status; no true randomisation sequence used }\end{array}$ \\
\hline $\begin{array}{l}\text { Allocation concealment } \\
\text { (selection bias) }\end{array}$ & Unclear risk & No details given \\
\hline $\begin{array}{l}\text { Blinding (performance } \\
\text { bias and detection bias) }\end{array}$ & Low risk & $\begin{array}{l}\text { Self-reported outcomes from participants not blinded to treatment condition, } \\
\text { but all received phone counselling and some self-help, so performance and } \\
\text { detection bias judged to be unlikely }\end{array}$ \\
\hline $\begin{array}{l}\text { Incomplete outcome data } \\
\text { (attrition bias) } \\
\text { All outcomes }\end{array}$ & Low risk & $\begin{array}{l}\text { 83\% of households completed } 12 \text { months' assessment; 76\% completed both 3 } \\
\text { months' and 12 months' assessment }\end{array}$ \\
\hline
\end{tabular}

Lipkus 1999

$\begin{array}{ll}\text { Methods } & \text { Setting: health centre, USA } \\ \text { Recruitment: from telephone survey of patients }\end{array}$

Participants 266 randomised, 160 followed up; low-income African American smokers, unselected by motivation; $52 \%$ female, $49 \%$ aged $>50$ years

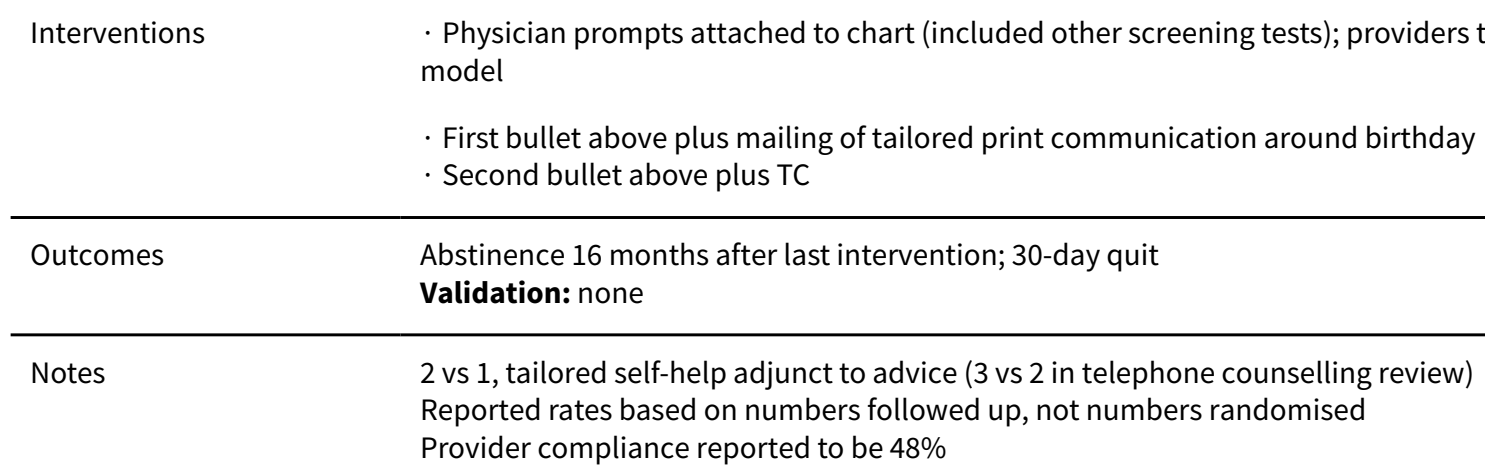

\section{Risk of bias}

\begin{tabular}{lll}
\hline Bias & Authors' judgement & Support for judgement \\
\hline $\begin{array}{l}\text { Random sequence genera- } \\
\text { tion (selection bias) }\end{array}$ & Unclear risk & Randomised; method not stated \\
\hline
\end{tabular}


Lipkus 1999 (Continued)

Allocation concealment $\quad$ Unclear risk $\quad$ No details given
(selection bias)

Blinding (performance Unclear risk

Unclear if participants were aware of what other participants were receiving;

bias and detection bias) no biochemical validation; self-help group has more communication than con-

All outcomes

trol group

Incomplete outcome data Low risk

(attrition bias)

$40 \%$ loss to follow-up, largely due to disconnected phone numbers

All outcomes

"Loss to follow-up did not appear to be a function of any demographic, psychosocial of smoking pattern, nor was it a function of the intervention smokers received"

Losses not included as smokers

McFall 1993

\begin{tabular}{ll}
\hline Methods & $\begin{array}{l}\text { Setting: community, USA } \\
\text { Recruitment: during a TV cessation programme }\end{array}$ \\
\hline Participants & Smokers who registered and received the manual or reported viewing at least 1 part of the programme \\
\hline $\begin{array}{l}\text { Interventions } \\
\cdot \text { TV programme and ALA FfS }\end{array}$ \\
\hline Outcomes & $\begin{array}{l}\text { Abstinence at } 12 \text { months (24 months' data reported but point prevalence with increase over time, so } \\
\text { does not represent a more conservative measure; RR similar) } \\
\text { Validation: none }\end{array}$ \\
\hline Notes & 2 vs 1, effect of additional materials \\
\hline
\end{tabular}

\section{Risk of bias}

\begin{tabular}{lll}
\hline Bias & Authors' judgement & Support for judgement \\
\hline $\begin{array}{l}\text { Random sequence genera- } \\
\text { tion (selection bias) }\end{array}$ & Unclear risk & Randomised; method not described \\
\hline $\begin{array}{l}\text { Allocation concealment } \\
\text { (selection bias) }\end{array}$ & Unclear risk & No details given \\
\hline $\begin{array}{l}\text { Blinding (performance } \\
\text { bias and detection bias) }\end{array}$ & Unclear risk & $\begin{array}{l}\text { Unclear if participants were aware of what other participants were receiving; } \\
\text { no biochemical validation; maintenance group has more communication than } \\
\text { control group }\end{array}$ \\
\hline $\begin{array}{l}\text { Incomplete outcome data } \\
\text { (attrition bias) }\end{array}$ & Low risk & $\begin{array}{l}\text { 24\% lost in maintenance condition, 27\% in control condition } \\
\text { All outcomes }\end{array}$ \\
\hline
\end{tabular}

Meyer 2008

\begin{tabular}{ll}
\hline Methods & Setting: primary healthcare centres, Germany \\
& Recruitment: smoking patients attending practices during 3 study weeks
\end{tabular}

Print-based self-help interventions for smoking cessation (Review) 
Meyer 2008 (Continued)

Participants Smokers, unselected for motivation; $48 \%$ female, average age 34, average cpd 16

\begin{tabular}{ll}
\hline Interventions & $\begin{array}{l}\text { - Assessment only control } \\
\text { - Up to } 3 \text { letters individually tailored to SoC - first used baseline assessment; } 3 \text { months and } 6 \text { months } \\
\text { depended on further assessment; stage-matched self-help manuals used } \\
\text { - Brief physician advice and self-help manuals }\end{array}$ \\
\hline Outcomes & $\begin{array}{l}\text { Abstinence at } 24 \text { months (sustained for } 6 \text { months) } \\
\text { Validation: none }\end{array}$ \\
\hline Notes & $\begin{array}{l}\text { Analyses in paper allowing for clustering yield slightly larger estimates than use of crude numbers on } \\
\text { quitting }\end{array}$ \\
& $\begin{array}{l}\text { Different assumptions about losses to follow up did not substantially alter any results } \\
\text { Abstinence rates increased over time in all groups }\end{array}$ \\
& $\begin{array}{l}\text { Prolonged abstinence at all follow-ups is very low - not used here; } 63 \% \text { got } 3 \text { letters, } 21 \% \text { got } 2, \text { and } \\
17 \% \text { only } 1\end{array}$ \\
\hline
\end{tabular}

\section{Risk of bias}

\begin{tabular}{lll}
\hline Bias & Authors' judgement & Support for judgement \\
\hline $\begin{array}{l}\text { Random sequence genera- } \\
\text { tion (selection bias) }\end{array}$ & High risk & $\begin{array}{l}\text { Quasi-random and clustered based on time of attendance; fixed sequence } \\
\text { of assessment-only, tailored letters, advice; at least 2 weeks between study } \\
\text { weeks }\end{array}$ \\
\hline $\begin{array}{l}\text { Allocation concealment } \\
\text { (selection bias) }\end{array}$ & High risk & Condition known at the time of recruitment \\
& $\begin{array}{l}\text { All patients screened, so recruitment bias should have been avoided; no evi- } \\
\text { dence of differences in baseline characteristics }\end{array}$ \\
\hline $\begin{array}{l}\text { Blinding (performance } \\
\text { bias and detection bias) } \\
\text { All outcomes }\end{array}$ & Unclear risk & $\begin{array}{l}\text { No validation but practice team, practitioner, and follow-up interviewers all } \\
\text { blinded; however unclear if control participants were aware of what interven- } \\
\text { tion participants were receiving }\end{array}$ \\
\hline $\begin{array}{l}\text { Incomplete outcome data } \\
\text { (attrition bias) }\end{array}$ & Low risk & $\begin{array}{l}56 \% \text { of intervention group and } 64 \% \text { of control group reached at 24 months; dif- } \\
\text { ferent approaches to missing data did not alter conclusions }\end{array}$ \\
\hline $\begin{array}{l}\text { All outcomes } \\
\end{array}$ & &
\end{tabular}

Meyer 2012

\begin{tabular}{ll}
\hline Methods & Setting: 151 general practices, Germany \\
& Recruitment: smoking patients attending practice \\
\hline Participants & $\begin{array}{l}3215 \text { patients (113 excluded), age } 18+, \text { who reported any tobacco smoking within last } 6 \text { months } \\
44 \% \text { female, average cpd not stated, average age } 41,38 \% \text { pre-contemplators }\end{array}$ \\
\hline Interventions & $\cdot$ Brief advice from practitioner (10 minutes) plus stage of change-specific self-help manuals \\
$\cdot$ & Two individually tailored computer-generated letters based on stage of change, plus self-help manu- \\
& $\cdot 1$ plus 2
\end{tabular}


Meyer 2012 (Continued)

Outcomes Abstinence at 12 months, self-reported as prolonged for previous 6 months

Validation: none

\begin{tabular}{ll}
\hline Notes & 3 vs 1 used as test of individually tailored self-help as adjunct to advice \\
& 2 vs 1 in Analysis 4.1; direct comparison of tailored materials and advice
\end{tabular}

\section{Risk of bias}

\begin{tabular}{lll}
\hline Bias & Authors' judgement & Support for judgement \\
\hline $\begin{array}{l}\text { Random sequence genera- } \\
\text { tion (selection bias) }\end{array}$ & High risk & $\begin{array}{l}\text { Cluster-randomised by practice } \\
\text { Practices randomly assigned before recruitment }\end{array}$ \\
& & $\begin{array}{l}\text { Study authors note: "randomization was seriously undermined by obviously } \\
\text { different mechanisms of patient selection for each study condition" }\end{array}$ \\
\hline $\begin{array}{l}\text { Allocation concealment } \\
\text { (selection bias) }\end{array}$ & High risk & $\begin{array}{l}\text { Practices not blind to condition when patients recruited; differential recruit- } \\
\text { ment rates by condition }\end{array}$ \\
\hline $\begin{array}{l}\text { Blinding (performance } \\
\text { bias and detection bias) } \\
\text { All outcomes }\end{array}$ & High risk & See above \\
\hline
\end{tabular}

\begin{tabular}{ll}
\hline $\begin{array}{l}\text { Incomplete outcome data } \\
\text { (attrition bias) }\end{array}$ & Low risk \\
All outcomes & $\begin{array}{l}30 \% \text { dropout in group 1, 21\% in group 2, 29\% in group } 3 \\
\\
\text { Study authors report that sensitivity analyses regarding assumptions about } \\
\text { participants lost to follow-up showed "same patterns of results" }\end{array}$ \\
\hline
\end{tabular}

Meyer 2016

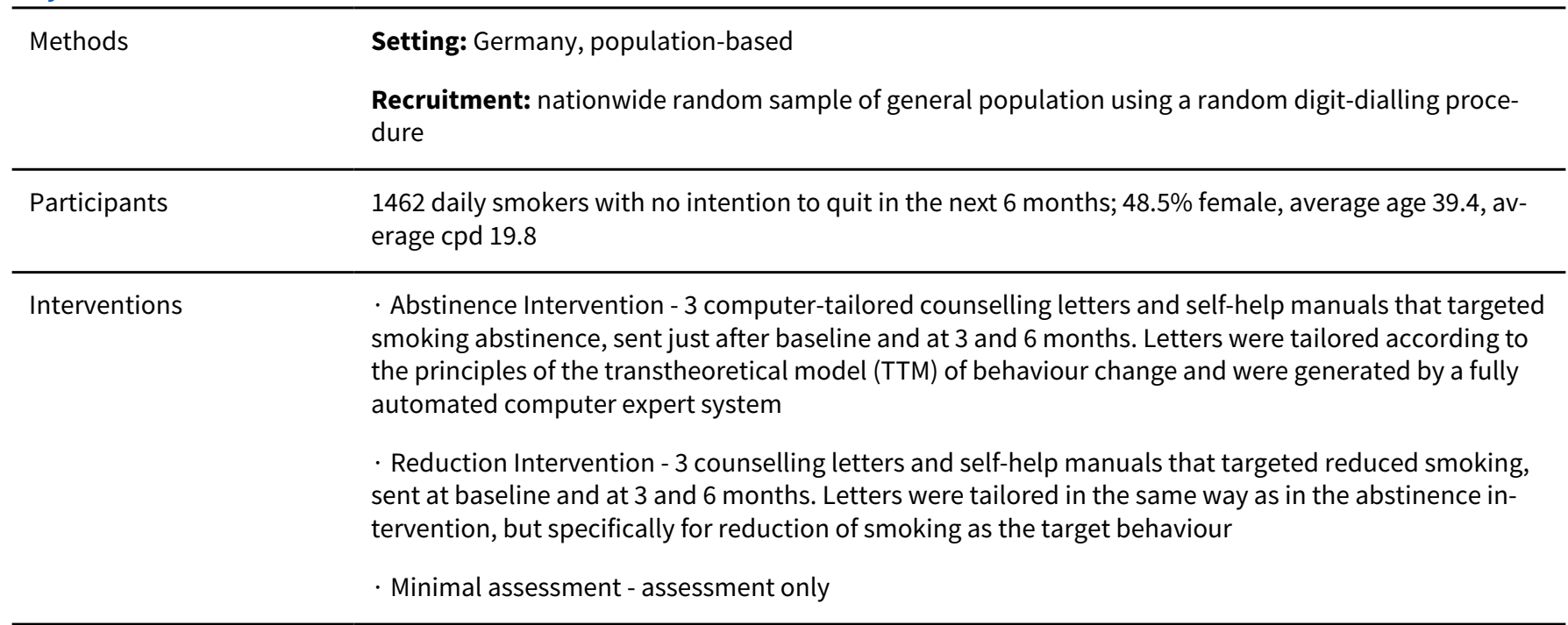

Outcomes

Strictest: 6 months' continuous abstinence at 24 months

Other: 12 months

Validation: none 
Meyer 2016 (Continued)

Notes
Funding: "Funding was gained from the German Federal Ministry of Education and Research (grant no. 01EB0120, 01EB0420, 01EE1406F) and the Social Ministry of the State of Mecklenburg-Vorpommern (grant no. IX311a 406.68.43.05)"

Declaration of interest: "The Project is part of the German research network EARLINT (EARLy substance use INTervention) and was supported by the research consortium on addiction, AERIAL. Funding was gained from the German Federal Ministry of Education and Research (grant no. 01EB0120, 01EB0420, 01EE1406F) and the Social Ministry of the State of Mecklenburg-Vorpommern (grant no. IX311a 406.68.43.05). None of the authors have other relevant financial disclosures"

\section{Risk of bias}

\begin{tabular}{lll}
\hline Bias & Authors' judgement & Support for judgement \\
\hline $\begin{array}{ll}\text { Random sequence genera- } \\
\text { tion (selection bias) }\end{array}$ & Low risk & $\begin{array}{l}\text { Quote: "The participants were randomized to the three study conditions via } \\
\text { a computer-based procedure. To increase the power of the comparisons be- } \\
\text { tween both intervention groups, we used a disproportional randomization al- } \\
\text { gorithm (Dumville et al., 2006), setting the allocation probability to } 36.8 \% \text { for } \\
\text { each intervention group and } 26.4 \% \text { for the assessment-only control group" }\end{array}$
\end{tabular}

\begin{tabular}{|c|c|c|}
\hline $\begin{array}{l}\text { Allocation concealment } \\
\text { (selection bias) }\end{array}$ & Low risk & Not specified, but no face-to-face contact with researchers \\
\hline $\begin{array}{l}\text { Blinding (performance } \\
\text { bias and detection bias) } \\
\text { All outcomes }\end{array}$ & Unclear risk & Not specified, but no objective measure of results \\
\hline $\begin{array}{l}\text { Incomplete outcome data } \\
\text { (attrition bias) } \\
\text { All outcomes }\end{array}$ & High risk & $\begin{array}{l}\text { Quote: "The number of participants lost to follow-up rate was significantly } \\
\text { higher (at month } 12 \text { : chi2-test, } d f=2, p<0.001 \text {; at month } 24 \text { : chi2- test, } d f=2 \text {, } \\
p<0.001 \text { ) in the intervention groups (at month } 12: 23 \% \text { reduction group, }[\ldots] \\
\text { at month } 24: \text { [...] } 27 \% \text { abstinence group) compared with the assessment-only } \\
\text { control group (at month } 12: 9 \% \text {; at month } 24: 16 \% \text { )" }\end{array}$ \\
\hline
\end{tabular}

Nollen 2007

$\begin{array}{ll}\text { Methods } & \text { Setting: hospital, USA } \\ & \text { Recruitment: smokers visiting hospital, interested in quitting in next } 6 \text { months }\end{array}$

\begin{tabular}{ll}
\hline Participants & 500 African American smokers; $60 \%$ female, average age 43, average cpd 20 \\
\hline Interventions & All participants received 8 weeks on nicotine patch and 2 phone calls \\
& Standard materials - ALA FfS plus How to Quit video \\
& Culturally sensitive guide Pathways to Freedom: Winning the Fight Against Tobacco, and Harlem \\
Health Connection's Kick-It video (40 minutes) targeted to African Americans
\end{tabular}

Outcomes Abstinence at 6 months (30-day point prevalence)

Validation: $\mathrm{CO}<10 \mathrm{ppm}$

Notes Study ID was Ahluwalia 1999 until publication of full report; minor change to results; comparison between targeted and untargeted materials; significantly more participants used targeted materials (68.8\% vs $59.6 \%)$ but no difference was detected in salience or in perceived materials

\section{Risk of bias}


Nollen 2007 (Continued)

Random sequence genera- Low risk Randomisation codes computer-generated by study statistician in blocks of 20 tion (selection bias)

Allocation concealment Unclear risk Described as investigator blinded, but no explicit statement provided
(selection bias)

(selection bias)

Blinding (performance $\quad$ Low risk $\quad$ Biochemical validation used; interventions of similar intensity
bias and detection bias)

All outcomes

Incomplete outcome data High risk

(attrition bias)

All outcomes
$66 \%$ lost to follow-up at 6 months, included in ITT analysis; no evidence of differential loss by group.

\section{Omenn 1988}

\begin{tabular}{ll}
\hline Methods & Setting: single worksite (13,000 workers, 9 employers), USA \\
& Recruitment: worksite volunteers
\end{tabular}

\begin{tabular}{ll}
\hline Participants & 243 smokers with preference for a self-help programme \\
\hline Interventions & $\begin{array}{l}\text { Only self-help format conditions considered in this review } \\
\text { - Multiple-component programme } \\
\text { - Relapse prevention programme } \\
\text { - Minimal treatment programme (American Cancer Society Quitter's Guide; 7-day plan) }\end{array}$ \\
\hline
\end{tabular}

$\begin{array}{ll}\text { Outcomes } & \begin{array}{l}\text { Abstinence at } 12 \text { months } \\ \text { Validation: saliva cotinine } \leq 35 \mathrm{ng} / \mathrm{mL}\end{array}\end{array}$

Notes Comparison between self-help materials; not in meta-analysis

No clinical or statistically significant differences between quit rates in the 3 groups

\section{Risk of bias}

\begin{tabular}{lll}
\hline Bias & Authors' judgement & Support for judgement \\
\hline $\begin{array}{l}\text { Random sequence genera- } \\
\text { tion (selection bias) }\end{array}$ & Low risk & $\begin{array}{l}\text { Quote: "nurses at aid stations using randomized assignment lists generated by } \\
\text { research centre, within preference for format" }\end{array}$ \\
\hline $\begin{array}{l}\text { Allocation concealment } \\
\text { (selection bias) }\end{array}$ & Unclear risk & No details given \\
\hline $\begin{array}{l}\text { Blinding (performance } \\
\text { bias and detection bias) } \\
\text { All outcomes }\end{array}$ & Low risk & Biochemical validation; interventions of similar intensities \\
\hline $\begin{array}{l}\text { Incomplete outcome data } \\
\text { (attrition bias) } \\
\begin{array}{l}\text { All outcomes } \\
\text { L }\end{array}\end{array}$ & Low risk & At least 89\% followed up in each arm; non-respondents counted as smokers \\
\hline
\end{tabular}

Orleans 1991

Methods Setting: HMO, USA

Print-based self-help interventions for smoking cessation (Review) 
Orleans 1991 (Continued)

Recruitment: largely through publicity in HMO magazine

\begin{tabular}{ll}
\hline Participants & 2021 smokers; 63\% female, average age 44, average cpd 26 \\
\hline Interventions & - Free \& Clear - 28-page guide incorporating nicotine fading and standard behavioural abstinence and \\
relapse prevention techniques. Also, a Quit Kit and ALA publication, A Lifetime of Freedom from Smoking \\
- Same materials as first bullet above plus 2 copies of a social support guide to be given to "allies" \\
- Same materials as second bullet above plus TC plus quitline \\
- Control - Referral guide describing available self-help guides and local resources, plus NCI publica- \\
tion, Clearing the Air
\end{tabular}

Outcomes Abstinence at 16 months for over 6 months by blinded telephone interview

Validation: saliva cotinine $<10 \mathrm{ng} / \mathrm{mL}$, or thiocyanate $<2400 \mu \mathrm{mol} / \mathrm{L}$ for gum users

Notes

1 plus 2 vs 4 , effect of self-help alone ( 3 assessed in TC review)

By 16 months, 59\% of participants in the control group reported that they had used an additional treatment method

\section{Risk of bias}

Bias Authors' judgement Support for judgement

Random sequence genera- Unclear risk Randomised; method not stated; stratified by living alone/not; advice to quit tion (selection bias) in last 12 months/not and nicotine content of cigarette brand

\begin{tabular}{lll}
\hline $\begin{array}{l}\text { Allocation concealment } \\
\text { (selection bias) }\end{array}$ & Unclear risk & No details given \\
\hline
\end{tabular}

Blinding (performance Low risk All arms included in this review received written material at similar levels of inbias and detection bias) tensity. Biochemical validation in sample at 16 months

All outcomes

"to improve the veracity of smoking self-report, all follow-up questionnaires and interviews began with a reminder that the subjects might be asked for a saliva specimen for nicotine assessment, creating a sort of 'bogus pipeline'"

\begin{tabular}{|c|c|c|}
\hline $\begin{array}{l}\text { Incomplete outcome data } \\
\text { (attrition bias) }\end{array}$ & Low risk & Loss to follow-up $6 \%$ at 16 months; did not differ across treatment groups \\
\hline All outcomes & & $\begin{array}{l}\text { Analyses based on respondents, including losses, would marginally increase } \\
\text { estimated effect }\end{array}$ \\
\hline
\end{tabular}

Orleans 1998

Setting: Community, USA
Recruitment: African American smokers calling a Cancer Information Service telephone counselling
line in response to a targeted campaign

\begin{tabular}{ll}
\hline Participants & 1422 African American smokers; average age not stated, 62\% in 20 to 39-year age group, median cpd 20 \\
\hline Interventions & $\begin{array}{l}\cdot \text { 36-page Pathways to Freedom guide and tailored TC. Guide used African American models and ad- } \\
\text { dressed specific obstacles } \\
\cdot \text { Standard guide Clearing the Air and standard NCl TC }\end{array}$ \\
\hline
\end{tabular}

\begin{tabular}{ll}
\hline Outcomes & Abstinence at 6 months, 7 -day point prevalence, telephone questionnaire (12 months' abstinence also \\
assessed in a sample of 445 smokers) \\
Validation: none
\end{tabular}

Notes Test of population targeting; counselling was also different for the 2 groups

Print-based self-help interventions for smoking cessation (Review) 
Orleans 1998 (Continued)

At 12 months, results showed significant differences $(15.0 \%$ vs $8.8 \%$ for the sample selected for follow-up)

\begin{tabular}{lll}
\hline Risk of bias & & \\
\hline Bias & Authors' judgement & Support for judgement \\
\hline $\begin{array}{l}\text { Random sequence genera- } \\
\text { tion (selection bias) }\end{array}$ & Low risk & $\begin{array}{l}\text { Randomised by last digit of caller's contact phone number; risk of bias proba- } \\
\text { bly low }\end{array}$ \\
\hline $\begin{array}{l}\text { Allocation concealment } \\
\text { (selection bias) }\end{array}$ & Low risk & $\begin{array}{l}\text { Presumably recruited before phone number and thus allocation known, so risk } \\
\text { of bias probably low }\end{array}$ \\
\hline $\begin{array}{l}\text { Blinding (performance } \\
\text { bias and detection bias) } \\
\text { All outcomes }\end{array}$ & High risk & $\begin{array}{l}\text { Self-reported outcomes from participants not blinded to treatment condition; } \\
\text { intervention includes personal contact with tailoring in one group }\end{array}$ \\
\hline $\begin{array}{l}\text { Incomplete outcome data } \\
\text { (attrition bias) } \\
\begin{array}{l}\text { All outcomes } \\
\text { L }\end{array}\end{array}$ & Low risk & $\begin{array}{l}37 \% \text { lost to follow-up at } 6 \text { months } \\
\text { No differential dropout }\end{array}$ \\
\hline
\end{tabular}

\section{Orleans 2000}

\begin{tabular}{ll}
\hline Methods & $\begin{array}{l}\text { Setting: community, USA } \\
\text { Recruitment: smokers aged }>65 \text { using nicotine patch }\end{array}$ \\
\hline Participants & 720 smokers; "mostly female", average age 72, average cpd 22 \\
\hline Interventions & $\begin{array}{l}\text { All participants had filled a prescription for nicotine patch } \\
\text { Clear Horizons guide for older smokers plus 7 personalised tailored computer-generated mailings } \\
\text { over } 6 \text { months } \\
\text { - Fact sheet on patch-assisted quitting }\end{array}$ \\
\hline Outcomes & $\begin{array}{l}\text { Abstinence at } 12 \text { months; } 7 \text {-day point prevalence } \\
\text { Validation: none (limited information in abstract) }\end{array}$ \\
\hline Notes & $\begin{array}{l}\text { Follow-up rates supplied by N Boyd } \\
\text { Considered with other studies testing self-help adjuncts to pharmacotherapy, not with other tailored } \\
\text { studies } \\
\text { "Tailored messages were based on past research identifying the factors associated with general quit- } \\
\text { ting success and with patch assisted quitting among older smokers" } \\
\text { Not based on individual characteristics }\end{array}$ \\
\hline
\end{tabular}

\section{Risk of bias}

\begin{tabular}{lll}
\hline Bias & Authors' judgement & Support for judgement \\
\hline $\begin{array}{l}\text { Random sequence genera- } \\
\text { tion (selection bias) }\end{array}$ & Unclear risk & Randomised; method not stated \\
\hline $\begin{array}{l}\text { Allocation concealment } \\
\text { (selection bias) }\end{array}$ & Unclear risk & No details given \\
\hline \hline
\end{tabular}


Orleans 2000 (Continued)

Blinding (performance Unclear risk Limited information in abstract; unclear if biochemical validation used bias and detection bias)

All outcomes

\begin{tabular}{ll}
$\begin{array}{l}\text { Incomplete outcome data } \\
\text { (attrition bias) }\end{array}$ & Low risk \\
\begin{tabular}{l} 
All outcomes \\
\hline
\end{tabular} & Non-responders included as smokers \\
\hline
\end{tabular}

Owen 1989

\begin{tabular}{|c|c|c|}
\hline Methods & \multicolumn{2}{|c|}{$\begin{array}{l}\text { Setting: community, Australia } \\
\text { Recruitment: advertisements for smokers wishing to quit }\end{array}$} \\
\hline Participants & \multicolumn{2}{|c|}{208 smokers; average age 42, average cpd 28} \\
\hline Interventions & \multicolumn{2}{|c|}{$\begin{array}{l}\text { - Quit Kit along with apology that course was full. Kit included a 5-day cessation plan } \\
\text { - Self-help programme in } 4 \text { mailed parts } \\
\text { - As in second bullet above, but personalised with additional text based on registration form (option to } \\
\text { send for additional materials) }\end{array}$} \\
\hline Outcomes & \multicolumn{2}{|c|}{$\begin{array}{l}\text { Abstinence at } 9 \text { months (point prevalence) } \\
\text { Validation: some cotinine assays but no correction for a possible 15\% misreport level }\end{array}$} \\
\hline Notes & \multicolumn{2}{|c|}{$\begin{array}{l}\text { First intervention listed above meets criteria for basic self-help, so } 2 \text { vs } 1 \text { for effect of additional materi- } \\
\text { als and } 3 \text { vs } 2 \text { for effect of personalised materials }\end{array}$} \\
\hline \multicolumn{3}{|l|}{ Risk of bias } \\
\hline Bias & Authors' judgement & Support for judgement \\
\hline $\begin{array}{l}\text { Random sequence genera- } \\
\text { tion (selection bias) }\end{array}$ & Unclear risk & Randomised; method not described \\
\hline $\begin{array}{l}\text { Allocation concealment } \\
\text { (selection bias) }\end{array}$ & Unclear risk & No details given \\
\hline $\begin{array}{l}\text { Blinding (performance } \\
\text { bias and detection bias) } \\
\text { All outcomes }\end{array}$ & High risk & $\begin{array}{l}\text { Control group (1) received notice that course was full; could introduce perfor- } \\
\text { mance bias by artificially decreasing control group quit rates }\end{array}$ \\
\hline $\begin{array}{l}\text { Incomplete outcome data } \\
\text { (attrition bias) } \\
\text { All outcomes }\end{array}$ & Unclear risk & $\begin{array}{l}12 \% \text { lost to follow-up at } 9 \text { months; similar between groups } \\
\text { Non-respondents included as smokers }\end{array}$ \\
\hline
\end{tabular}

\section{Pallonen 1994}

$\begin{array}{ll}\text { Methods } & \text { Setting: community cardiovascular risk factor study, Finland } \\ \text { Recruitment: male smokers identified via survey }\end{array}$

\section{Participants}

165 male smokers who were classified as pre-contemplators or contemplators according to the SoC model; average age 52 years, average cpd 19 
Pallonen 1994 (Continued)

Interventions
- Self-help: five 10 to 20 -page self-help manuals matched to SoC; mailed after each 6-month assessment

- Usual care and annual telephone assessment

\section{Outcomes Sustained abstinence at 2 years (point prevalence) \\ Validation: none}

Notes

Included in main analysis although targeted materials

Demoninators are smokers for whom complete follow-up data were available

\section{Risk of bias}

\begin{tabular}{lll}
\hline Bias & Authors' judgement & Support for judgement \\
\hline $\begin{array}{l}\text { Random sequence genera- } \\
\text { tion (selection bias) }\end{array}$ & Unclear risk & $\begin{array}{l}\text { Randomised in 2:1 ratio, but prepared smokers in treatment condition then of- } \\
\text { fered clinic, so groups were not balanced by SoC }\end{array}$ \\
\hline $\begin{array}{l}\text { Allocation concealment } \\
\text { (selection bias) }\end{array}$ & Unclear risk & No details given \\
\hline $\begin{array}{l}\text { Blinding (performance } \\
\text { bias and detection bias) } \\
\text { All outcomes }\end{array}$ & Unclear risk & $\begin{array}{l}\text { Unclear if control participants knew the nature of the intervention; no bio- } \\
\text { chemical validation; different intensities of intervention }\end{array}$ \\
\hline $\begin{array}{l}\text { Incomplete outcome data } \\
\text { (attrition bias) } \\
\text { All outcomes }\end{array}$ & Unclear risk & $\begin{array}{l}\text { 37\% lost to follow-up by 2 years and not re-included in MA, as group not given } \\
\text { Study authors report sensitivity analysis of effect of excluding people with in- } \\
\text { complete follow-up and state that bias was not introduced }\end{array}$ \\
\hline
\end{tabular}

Parekh 2014

$\begin{array}{ll}\text { Methods } & \text { Setting: } 21 \text { general practices, Australia } \\ \text { Recruitment: letters to patients identified via practice records }\end{array}$

Participants

Approximately 400 people who completed a baseline health behaviour questionnaire and were not non-smokers ( $14 \%$ of participants). Aged 18 to 70 years, had consulted in previous 6 months, $69 \%$ female, average age 46.9 years (all participants)

Interventions
- Single Intervention - feedback on combined health score and personalised computer-tailored advice (addressing smoking, diet, physical activity, and BMI), plus 1-page health promotion information sheets for each behaviour that did not meet national guidelines
- Dual intervention - as in first bullet above plus additional assessment and computerised feedback at 3 months
- Dual control - as in first bullet above but without combined health score, and addressing other health behaviours (immunisation, protection behaviour, non-smoking policies in home, screening; none of the items in the first bullet above)

- As per the third bullet above plus additional assessment and computerised feedback at 3 months

\begin{tabular}{ll}
\hline Outcomes & Abstinence at 12 months; self-reported \\
\hline Notes & Multiple risk factor intervention; only a minority of participants were smokers \\
& Intervention tailored to health risks; smoking materials not individually tailored \\
\hline
\end{tabular}


Parekh 2014 (Continued)

Numbers of smokers at baseline and follow-up estimated from percentages

Dual and single arms combined in comparison 1.1.2/2.1.2

\section{Risk of bias}

\begin{tabular}{lll}
\hline Bias & Authors' judgement & Support for judgement \\
\hline $\begin{array}{l}\text { Random sequence genera- } \\
\text { tion (selection bias) }\end{array}$ & Low risk & "permuted block procedure stratified by GP” \\
\hline $\begin{array}{l}\text { Allocation concealment } \\
\text { (selection bias) }\end{array}$ & Unclear risk & Not reported \\
\hline $\begin{array}{l}\text { Blinding (performance } \\
\text { bias and detection bias) } \\
\text { All outcomes }\end{array}$ & Low risk & "participants were blinded to the group to which they were randomized" \\
\hline
\end{tabular}

Incomplete outcome data Unclear risk Dropouts reported only for all participants - not for smokers
(attrition bias)

All outcomes

Pederson 1983

$\begin{array}{ll}\text { Methods } & \text { Setting: respiratory specialist outpatient clinic, USA } \\ \text { Recruitment: all smokers attending (unselected) }\end{array}$

\begin{tabular}{ll}
\hline Participants & 75 smokers; average age 52, average cpd 25 \\
\hline Interventions & $\begin{array}{l}\text { - Advice to quit, and effects of smoking on present health, from respiratory specialist } \\
\text { - Advice and self-help manual, Break the Smoking Habit: A Behavioral Program for Giving Up Cigarettes } \\
\text { (Pomerleau \& Pomerleau) }\end{array}$ \\
\hline Outcomes & $\begin{array}{l}\text { Abstinence at } 6 \text { months (self-report of no smoking for } 3 \text { months via telephone interview) } \\
\text { Validation: none }\end{array}$ \\
\hline Notes & $\begin{array}{l}\text { Due to quasi-random allocation, a sensitivity analysis of the effect of excluding this study is reported in } \\
\text { the discussion }\end{array}$
\end{tabular}

\begin{tabular}{lll}
\hline Risk of bias & \\
\hline Bias & Authors' judgement & Support for judgement \\
\hline $\begin{array}{l}\text { Random sequence genera- } \\
\text { tion (selection bias) }\end{array}$ & High risk & $\begin{array}{l}\text { Quasi-random assignment by week of attendance; possibility of baseline dif- } \\
\text { ferences }\end{array}$ \\
\hline $\begin{array}{l}\text { Allocation concealment } \\
\text { (selection bias) }\end{array}$ & High risk & $\begin{array}{l}\text { Not concealed, so risk of bias present, although all eligible patients at a clinic } \\
\text { were supposed to be recruited, thus avoiding selection bias }\end{array}$ \\
\hline $\begin{array}{l}\text { Blinding (performance } \\
\text { bias and detection bias) }\end{array}$ & Low risk & $\begin{array}{l}\text { No biochemical validation but self-report not given to physician; control group } \\
\text { not aware of intervention content; equal amounts of physician contact in both } \\
\text { groups, so differential misreport judged to be unlikely }\end{array}$ \\
\hline $\begin{array}{l}\text { Incomplete outcome data } \\
\text { (attrition bias) } \\
\text { All outcomes }\end{array}$ & Low risk & 5 lost in intervention arm, 1 in control arm; included as non-responders in MA \\
\hline \hline
\end{tabular}


Prochaska 1993

\begin{tabular}{|c|c|}
\hline Methods & $\begin{array}{l}\text { Setting: community, USA } \\
\text { Recruitment: advertisements for volunteers to test self-help materials }\end{array}$ \\
\hline Participants & $\begin{array}{l}756 \text { smokers (93 pre-contemplation, } 435 \text { contemplation, } 228 \text { preparation; } 569 \text { in relevant arms); aver- } \\
\text { age age 43, average cpd } 27\end{array}$ \\
\hline Interventions & $\begin{array}{l}\text { - Standard self-help - ALA FfS, A Lifetime of Freedom from Smoking, } 50 \text { Most Often Asked Questions } \\
\text { - Targeted manuals - } 5 \text { covering pre-contemplation, contemplation, action, maintenance, and relapse. } \\
\text { Participants were sent manual for their SoC and subsequent ones, except for relapse, which was sent } \\
\text { following an assessment at which relapse occurred } \\
\text { - Tailored Interactive - in addition to manuals, participants were sent personalised reports in response } \\
\text { to questionnaires } \\
\text { - Counsellor telephone calls - same as third bullet above with short calls at } 0,1,3 \text {, and } 6 \text { months (not } \\
\text { included in this review) }\end{array}$ \\
\hline
\end{tabular}

Outcomes Sustained abstinence at 18 months (12 months and 18 months)

Validation: none; participants were asked for names of significant others but these were not contacted

\begin{tabular}{ll}
\hline Notes & vs 1 targeting, 3 vs 2 tailoring \\
& Numbers randomised and quit rates as shown on graphs obtained from study authors
\end{tabular}

\section{Risk of bias}

\begin{tabular}{|c|c|c|}
\hline Bias & Authors' judgement & Support for judgement \\
\hline $\begin{array}{l}\text { Random sequence genera- } \\
\text { tion (selection bias) }\end{array}$ & Unclear risk & Randomised; method not stated; stratified by SoC \\
\hline $\begin{array}{l}\text { Allocation concealment } \\
\text { (selection bias) }\end{array}$ & Unclear risk & No details given \\
\hline $\begin{array}{l}\text { Blinding (performance } \\
\text { bias and detection bias) } \\
\text { All outcomes }\end{array}$ & Low risk & $\begin{array}{l}\text { "Bogus pipeline" approach; names of significant others asked for but not con- } \\
\text { tacted } \\
\text { Similar intensities across interventions (all received manuals) }\end{array}$ \\
\hline $\begin{array}{l}\text { Incomplete outcome data } \\
\text { (attrition bias) } \\
\text { All outcomes }\end{array}$ & Low risk & $\begin{array}{l}\text { Attrition at each assessment averaged } 5.5 \% \text { - not significantly different across } \\
\text { conditions } \\
\text { Non-respondents included as smokers in meta-analysis }\end{array}$ \\
\hline
\end{tabular}

Prochaska 2001a

\begin{tabular}{ll}
\hline Methods & $\begin{array}{l}\text { Setting: managed care organisation, USA } \\
\text { Recruitment: smokers identified by survey of members; } 85 \% \text { recruited to a study }\end{array}$ \\
\hline Participants & 1447 smokers (967 at 18 months' follow-up); 56\% female, average age 38, average cpd 20 \\
\hline Interventions & $\begin{array}{l}\text { - Assessment only (completed questionnaires on } 4 \text { occasions) } \\
\text { - Expert system - tailored } 2 \text { to 3-page report at } 0 \text { months, } 3 \text { months, and } 6 \text { months, and SoC-matched } \\
\text { manual } \\
\text { - As second bullet above plus telephone counselling } \\
\text { - As third bullet above plus computer for scheduled cigarette reduction }\end{array}$ \\
\hline
\end{tabular}


Prochaska 2001a (Continued)

Outcomes

Abstinence at 18 months, sustained for 6 months (other measures of abstinence also reported)

Validation: none

Notes

2 vs 1 , tailoring. 3 contributes to telephone counselling review; 4 not included

Arm 2 is also evaluated in Velicer 1999 results

\section{Risk of bias}

\begin{tabular}{|c|c|c|}
\hline Bias & Authors' judgement & Support for judgement \\
\hline $\begin{array}{l}\text { Random sequence genera- } \\
\text { tion (selection bias) }\end{array}$ & Unclear risk & Randomised; method not described \\
\hline $\begin{array}{l}\text { Allocation concealment } \\
\text { (selection bias) }\end{array}$ & Unclear risk & No details given \\
\hline $\begin{array}{l}\text { Blinding (performance } \\
\text { bias and detection bias) } \\
\text { All outcomes }\end{array}$ & Unclear risk & $\begin{array}{l}\text { Self-reported outcomes from participants not blinded to treatment condition; } \\
\text { treatment more intensive than control, and no information on blinding report- } \\
\text { ed }\end{array}$ \\
\hline $\begin{array}{l}\text { Incomplete outcome data } \\
\text { (attrition bias) } \\
\text { All outcomes }\end{array}$ & Low risk & $\begin{array}{l}\text { MA includes losses to follow-up and refusals } \\
\text { Study author analysis suggests ITT analysis is biased } \\
\text { Sensitivity analysis (comparison 99) tests impact on outcome }\end{array}$ \\
\hline
\end{tabular}

Prochaska 2001b

\begin{tabular}{|c|c|c|}
\hline Methods & \multicolumn{2}{|c|}{$\begin{array}{l}\text { Setting: community, USA } \\
\text { Recruitment: random digit dialling; } 80 \% \text { of smokers reached recruited }\end{array}$} \\
\hline Participants & \multicolumn{2}{|c|}{4144 smokers ( 2571 at 24 -month follow up); 55\% female, average age 41 years, average cpd 20} \\
\hline Interventions & \multicolumn{2}{|c|}{$\begin{array}{l}\text { - Assessment only (questioned at 6-month intervals) } \\
\text { - Expert System; see Prochaska 2001a }\end{array}$} \\
\hline Outcomes & \multicolumn{2}{|c|}{$\begin{array}{l}\text { Abstinence at } 24 \text { months, sustained for } 6 \text { months (other measures of abstinence also reported) } \\
\text { Validation: none }\end{array}$} \\
\hline Notes & \multicolumn{2}{|l|}{2 vs 1 , tailoring } \\
\hline \multicolumn{3}{|l|}{ Risk of bias } \\
\hline Bias & Authors' judgement & Support for judgement \\
\hline $\begin{array}{l}\text { Random sequence genera- } \\
\text { tion (selection bias) }\end{array}$ & Unclear risk & Randomised; method not described \\
\hline $\begin{array}{l}\text { Allocation concealment } \\
\text { (selection bias) }\end{array}$ & Unclear risk & No details given \\
\hline $\begin{array}{l}\text { Blinding (performance } \\
\text { bias and detection bias) } \\
\text { All outcomes }\end{array}$ & Unclear risk & $\begin{array}{l}\text { No information on blinding provided; no validation; interventions at different } \\
\text { levels of intensity, so differential misreport judged possible }\end{array}$ \\
\hline
\end{tabular}


Prochaska 2001b (Continued)

Incomplete outcome data Low risk Similar rates of loss to follow-up but slightly higher refusal in intervention arm (attrition bias)

Non-respondents included as smokers in meta-analysis

All outcomes

Sensitivity analysis (comparison 99) tests impact on outcome

Prochaska 2004

$\begin{array}{ll}\text { Methods } & \text { Setting: community, USA } \\ \text { Recruitment: parents of ninth grade students in a separate study; at risk for one of the targeted health } \\ \text { behaviours }\end{array}$
behaviours

\begin{tabular}{|c|c|c|}
\hline Participants & \multicolumn{2}{|c|}{$\begin{array}{l}711 \text { smokers from total of } 2460 \text { participants; } 75 \% \text { female (full sample), average age } 43 \text { years (full), aver- } \\
\text { age cpd } 18,41 \% \text { at pre-contemplation phase, } 41 \% \text { contemplators, } 18 \% \text { in preparation }\end{array}$} \\
\hline Interventions & \multicolumn{2}{|c|}{$\begin{array}{l}\text { - Assessment only (completed questionnaires on } 3 \text { occasions) } \\
\text { - Expert system - tailored } 3 \text { to 5-page report at } 0 \text { months, } 6 \text { months, and } 12 \text { months and manual }\end{array}$} \\
\hline Outcomes & \multicolumn{2}{|c|}{$\begin{array}{l}\text { Abstinence at } 24 \text { months sustained for } 6 \text { months (other measures of abstinence also reported) } \\
\text { Validation: none }\end{array}$} \\
\hline Notes & \multicolumn{2}{|l|}{2 vs 1 , tailoring } \\
\hline \multicolumn{3}{|l|}{ Risk of bias } \\
\hline Bias & Authors' judgement & Support for judgement \\
\hline $\begin{array}{l}\text { Random sequence genera- } \\
\text { tion (selection bias) }\end{array}$ & Unclear risk & Randomised; method not described \\
\hline $\begin{array}{l}\text { Allocation concealment } \\
\text { (selection bias) }\end{array}$ & Unclear risk & No details given \\
\hline $\begin{array}{l}\text { Blinding (performance } \\
\text { bias and detection bias) } \\
\text { All outcomes }\end{array}$ & Unclear risk & $\begin{array}{l}\text { No information on blinding provided; no validation; interventions at different } \\
\text { levels of intensity, so differential misreport judged possible }\end{array}$ \\
\hline $\begin{array}{l}\text { Incomplete outcome data } \\
\text { (attrition bias) } \\
\text { All outcomes }\end{array}$ & Low risk & $\begin{array}{l}\text { Slightly higher loss to follow-up in Intervention (45\%) than in control (40\%) } \\
\text { All participants included in this meta-analysis }\end{array}$ \\
\hline
\end{tabular}

Prochaska 2005

\begin{tabular}{ll}
\hline Methods & $\begin{array}{l}\text { Setting: community, USA } \\
\text { Recruitment: primary care patients proactively recruited by phone; at risk for one of the targeted } \\
\text { health behaviours }\end{array}$ \\
\hline Participants & $\begin{array}{l}1211 \text { smokers from total of } 5407 \text { participants; } 70 \% \text { female (full sample), average age } 45 \text { years (full), av- } \\
\text { erage cpd } 17,31 \% \text { at pre-contemplation phase, } 46 \% \text { contemplators, } 23.5 \% \text { in preparation }\end{array}$ \\
\hline Interventions & $\begin{array}{l}\text { - Assessment only (completed questionnaires on } 3 \text { occasions) } \\
\cdot \text { Expert system - tailored } 3 \text { to 5-page report at } 0 \text { months, } 6 \text { months, and } 12 \text { months and manual }\end{array}$ \\
\hline Outcomes & Abstinence at 24 months; point prevalence \\
\hline
\end{tabular}

Print-based self-help interventions for smoking cessation (Review) 
Prochaska 2005 (Continued)

\section{Validation: none}

Notes 1 , tailoring
Sustained abstinence also an outcome
"same pattern of results" but details not reported
Number of smokers by group at baseline not reported; data requested

\section{Risk of bias}

\begin{tabular}{lll}
\hline Bias & Authors' judgement & Support for judgement \\
\hline $\begin{array}{l}\text { Random sequence genera- } \\
\text { tion (selection bias) }\end{array}$ & Unclear risk & Randomised; method not described \\
\hline $\begin{array}{l}\text { Allocation concealment } \\
\text { (selection bias) }\end{array}$ & Unclear risk & No details given \\
\hline $\begin{array}{l}\text { Blinding (performance } \\
\text { bias and detection bias) }\end{array}$ & Unclear risk & $\begin{array}{l}\text { Telephone assessors blinded but unclear if participants knew the nature of the } \\
\text { oll outcomes arm; no validation; interventions at different levels of intensity, so differ- } \\
\text { ential misreport judged possible }\end{array}$ \\
\hline $\begin{array}{l}\text { Incomplete outcome data } \\
\text { (attrition bias) } \\
\text { All outcomes }\end{array}$ & Unclear risk & $\begin{array}{l}\text { 35\% loss to follow-up at 24 months } \\
\text { Insufficient data to include non-respondents in meta-analysis, but no interac- } \\
\text { tion between missing data and intervention }\end{array}$ \\
\hline
\end{tabular}

\section{Prue 1983}

Setting: Veterans Administration Medical Center outpatient clinic, USA
Recruitment: smokers who could not attend clinic sessions referred to smoking treatment pro-
gramme (selected)

\begin{tabular}{ll}
\hline Participants & 40 smokers (likely to be predominantly male); average age 45 years, average cpd 32 \\
\hline Interventions & $\begin{array}{l}\text { - Self-help programme (Pomerleau \& Pomerleau) preceded by brand fading schedule; also telephone } \\
\text { calls from psychologists } \\
\cdot \text { Wait-list control }\end{array}$
\end{tabular}

\begin{tabular}{ll}
\hline Outcomes & $\begin{array}{l}\text { Point prevalence abstinence at } 6 \text { months' follow-up (wait-list treated after } 6 \text { months) } \\
\text { Validation: significant other only }\end{array}$
\end{tabular}

\begin{tabular}{ll}
\hline Notes & This is a minimal contact programme rather than a strict self-help one; marginal for inclusion; very \\
small impact on meta-analysis effects
\end{tabular}

\section{Risk of bias}

\begin{tabular}{lll}
\hline Bias & Authors' judgement & Support for judgement \\
\hline $\begin{array}{l}\text { Random sequence genera- } \\
\text { tion (selection bias) }\end{array}$ & Unclear risk & Randomised; method not described; unbalanced group size \\
\hline $\begin{array}{l}\text { Allocation concealment } \\
\text { (selection bias) }\end{array}$ & Unclear risk & No details given \\
\hline
\end{tabular}


Prue 1983 (Continued)

Blinding (performance High risk Wait-list control; performance bias possible bias and detection bias)

All outcomes

$\begin{array}{ll}\begin{array}{l}\text { Incomplete outcome data } \\ \text { (attrition bias) }\end{array} & \text { Low risk } \\ \text { All outcomes } & \text { ed }\end{array}$

Resnicow 1997

\begin{tabular}{ll}
\hline Methods & Setting: predominantly African American community in USA \\
& Recruitment: in healthcare, church, and public housing settings; presented as 'health promotion' - \\
not smoking cessation
\end{tabular}

\begin{tabular}{ll}
\hline Participants & 650 smokers who completed follow-up interviews recruited in treatment channels and 504 in control \\
channels (attrition similar between groups) \\
Average age 45 years, average cpd 16
\end{tabular}

\begin{tabular}{ll}
\hline Interventions & Self-help kit including Kick It guide, video, and aids; bimonthly mailings and single booster telephone \\
call & Health education materials not exclusively addressing smoking, and a cholesterol education video
\end{tabular}

\begin{tabular}{ll}
\hline Outcomes & $\begin{array}{l}\text { Point prevalence at } 6 \text { months } \\
\text { Validation: none }\end{array}$ \\
\hline Notes & Less than a third of intervention group received telephone call \\
& Post hoc analysis reported significantly higher quit rates amongst call than no call group \\
& Multi-variate analysis controlling for intracluster correlation gives OR of quitting in treatment group as \\
& 1.36 ( $95 \% \mathrm{Cl} 0.87$ to 2.11$)$ compared to OR 1.42 ( $95 \% \mathrm{Cl} 0.98$ to 2.04$)$ from figures used in meta-analysis \\
\hline
\end{tabular}

\section{Risk of bias}

\begin{tabular}{lll}
\hline Bias & Authors' judgement & Support for judgement \\
\hline $\begin{array}{l}\text { Random sequence genera- } \\
\text { tion (selection bias) }\end{array}$ & Unclear risk & $\begin{array}{l}\text { Cluster-randomised; stratified by type of site before recruitment of smokers; } \\
\text { method of sequence generation not reported }\end{array}$ \\
\hline $\begin{array}{l}\text { Allocation concealment } \\
\text { (selection bias) }\end{array}$ & High risk & $\begin{array}{l}\text { Allocation known at time of recruitment; unclear whether this introduced high } \\
\text { risk of bias; all participants received smoking cessation materials }\end{array}$ \\
\hline $\begin{array}{l}\text { Blinding (performance } \\
\text { bias and detection bias) } \\
\text { All outcomes }\end{array}$ & High risk & $\begin{array}{l}\text { No biochemical validation and differential levels of contact between groups } \\
\text { (including additional phone call); differential misreport judged possible }\end{array}$ \\
\hline $\begin{array}{l}\text { Incomplete outcome data } \\
\text { (attrition bias) } \\
\text { All outcomes }\end{array}$ & Low risk & $\begin{array}{l}\text { Attrition similar between treatment (7.5\%) and control (6.8\%) conditions } \\
\text { Non-respondents did not differ on baseline characteristics; not included in } \\
\text { meta-analysis denominators }\end{array}$ \\
\hline
\end{tabular}

\begin{tabular}{ll}
\hline Methods & Setting: hospital clinic, USA \\
& Recruitment: by health professional and self-referral
\end{tabular}


Rice 1994 (Continued)

\begin{tabular}{|c|c|c|}
\hline Participants & \multicolumn{2}{|c|}{406 smokers with a cardiovascular health problem } \\
\hline Interventions & \multicolumn{2}{|c|}{$\begin{array}{l}\text { Self-help materials - Smokeless } 6 \text { booklet programme and individual nurse counselling } \\
\text { - Self-help materials and group meetings } \\
\text { - Self-help alone - prompted to open envelope containing booklets on same schedule as other groups } \\
\text { - Advice to quit from nurse only }\end{array}$} \\
\hline Outcomes & \multicolumn{2}{|c|}{$\begin{array}{l}\text { Abstinence at } 12 \text { months } \\
\text { Validation: saliva thiocyanate tested but rates not corrected for misreport }\end{array}$} \\
\hline Notes & \multicolumn{2}{|c|}{$\begin{array}{l}3 \text { vs } 4 \text {, self-help vs control } \\
1 \text { and } 2 \text { not used in this review }\end{array}$} \\
\hline \multicolumn{3}{|l|}{ Risk of bias } \\
\hline Bias & Authors' judgement & Support for judgement \\
\hline $\begin{array}{l}\text { Random sequence genera- } \\
\text { tion (selection bias) }\end{array}$ & Unclear risk & $\begin{array}{l}\text { Randomised; method not stated } \\
\text { Stratified by sex, smoking history, and history of cardiovascular incident }\end{array}$ \\
\hline $\begin{array}{l}\text { Allocation concealment } \\
\text { (selection bias) }\end{array}$ & Unclear risk & No details given \\
\hline $\begin{array}{l}\text { Blinding (performance } \\
\text { bias and detection bias) } \\
\text { All outcomes }\end{array}$ & Unclear risk & $\begin{array}{l}\text { Biochemical validation conducted but not reported; unclear if participants } \\
\text { knew what other arms were receiving; arms involved differing levels of intensi- } \\
\text { ty }\end{array}$ \\
\hline $\begin{array}{l}\text { Incomplete outcome data } \\
\text { (attrition bias) } \\
\text { All outcomes }\end{array}$ & Low risk & $\begin{array}{l}8 \% \text { did not provide data at final follow-up and were counted as smokers in fi- } \\
\text { nal analysis; } 12 \text { died before follow-up and were not included in final outcome } \\
\text { figures }\end{array}$ \\
\hline Other bias & Unclear risk & Differential non-participation by experimental group assignments \\
\hline
\end{tabular}

\section{Schofield 1999}

\begin{tabular}{ll}
\hline Methods & Setting: hospital, Australia \\
& Recruitment: smokers discharged from hospital (unselected)
\end{tabular}

Participants 2465 smokers or recent quitters (excludes 1693 randomised but lost at 12-month follow-up)

No differential dropout; 59\% followed up in each arm; no demographic data

\begin{tabular}{ll}
\hline Interventions & Self-help 31-page SoC-based booklet + personally addressed letter from consultant stating health \\
risks and urging to quit \\
$\cdot$ Usual care
\end{tabular}

Outcomes Abstinence at 12 months and at 6 months

Validation: urine cotinine $\leq 50 \mathrm{ng} / \mathrm{mL}$ or $\mathrm{CO} \leq 8 \mathrm{ppm}$ for sample

Refusers (22\% in each group) classified as smokers

Self-help; no contact
Study authors reported benefit for subgroup for whom quitting was highly relevant to diagnosis


Schofield 1999 (Continued)

Risk of bias

\begin{tabular}{lll}
\hline Bias & Authors' judgement & Support for judgement \\
\hline $\begin{array}{l}\text { Random sequence genera- } \\
\text { tion (selection bias) }\end{array}$ & Low risk & $\begin{array}{l}\text { Randomised: "alternately allocated to intervention or control conditions by } \\
\text { computer" }\end{array}$ \\
\hline $\begin{array}{l}\text { Allocation concealment } \\
\text { (selection bias) }\end{array}$ & Low risk & $\begin{array}{l}\text { Smokers identified at time of admission and allocation determined at that } \\
\text { time }\end{array}$ \\
\hline $\begin{array}{l}\text { Blinding (performance } \\
\text { bias and detection bias) }\end{array}$ & Low risk & Mailing of materials done by medical records office \\
$\begin{array}{l}\text { All outcomes } \\
\begin{array}{l}\text { Incomplete outcome data } \\
\text { (attrition bias) } \\
\text { All outcomes }\end{array}\end{array}$ & Low risk & $\begin{array}{l}\text { Control group does not appear to have been aware of intervention condition; } \\
\text { biochemical validation used }\end{array}$ \\
\hline
\end{tabular}

Schumann 2008

$\begin{array}{ll}\text { Methods } & \text { Setting: community, Germany } \\ & \text { Recruitment: from participants in a general population health examination survey }\end{array}$

Participants 847 smokers (ex-smokers in study not included here); $46 \%$ female (full sample), average age 44 years (full), average cpd 15

Controls more likely to be in preparation ( $32 \%$ vs $20 \%$ ) and to have past year quit attempt

\begin{tabular}{ll}
\hline Interventions & $\begin{array}{l}\cdot \text { Assessment only (completed questionnaires on } 3 \text { occasions) } \\
\cdot \text { Expert system - tailored } 3 \text { to 4-page letter and } 8 \text { to } 26 \text {-page SoC-matched booklet at } 0 \text { months, } 3 \\
\text { months, and } 6 \text { months }\end{array}$ \\
\hline Outcomes & $\begin{array}{l}\text { Abstinence at } 24 \text { months; sustained } 18 \text { months' follow-up (other measures of abstinence also reported) } \\
\text { Validation: none }\end{array}$
\end{tabular}

Notes Tailoring - $67 \%$ got 3 letters, $21 \% 2,13 \%$ only 1

$72 \%$ reported reading some materials

\section{Risk of bias}

\begin{tabular}{lll}
\hline Bias & Authors' judgement & Support for judgement \\
\hline $\begin{array}{l}\text { Random sequence genera- } \\
\text { tion (selection bias) }\end{array}$ & Low risk & $\begin{array}{l}\text { Each participant was assigned a unique computer-generated random number } \\
\text { between } 0 \text { and } 1 \text {; the data file was sorted by ascending random numbers; par- } \\
\text { ticipants were then consecutively assigned to the 3 study conditions }\end{array}$ \\
\hline $\begin{array}{l}\text { Allocation concealment } \\
\text { (selection bias) }\end{array}$ & Low risk & No opportunity to alter allocation or exclude \\
\hline $\begin{array}{l}\text { Blinding (performance } \\
\text { bias and detection bias) } \\
\text { All outcomes }\end{array}$ & Low risk & Although no biochemical validation, written contact only; participants in con- \\
trol group do not appear to have known of intervention; all participants en-
\end{tabular}


Schumann 2008 (Continued)

gaged in long-term questionnaires re smoking status, so differential misreport judged unlikely

\begin{tabular}{ll}
\hline $\begin{array}{l}\text { Incomplete outcome data } \\
\text { (attrition bias) }\end{array}$ & Low risk \\
All outcomes & Somewhat greater loss in intervention (34\%) than in control (27\%) \\
& Meta-analysis includes those lost as smokers \\
& Study authors report that generalized estimation equation gave similar results
\end{tabular}

Smith 2004

\begin{tabular}{|c|c|c|}
\hline Methods & \multicolumn{2}{|c|}{$\begin{array}{l}\text { Setting: } 10 \text { communities, Canada } \\
\text { Recruitment: volunteers intending to quit }\end{array}$} \\
\hline Participants & \multicolumn{2}{|c|}{632 smokers (423 in relevant arms); $61 \%$ female, average age 42 years, $61 \%$ had prior use of NRT } \\
\hline Interventions & \multicolumn{2}{|c|}{$\begin{array}{l}\text { Factorial design comparing } 2 \text { intensities of TC and } 2 \text { types of print materials } \\
\text { - Booklet (Canadian Cancer Society (CCS) - One Step at a Time - } 44 \text { pages) } \\
\text { - Pamphlet (CCS How to Quit Smoking - single page) } \\
\text { TC conditions collapsed; booklet-only control group not used in the review }\end{array}$} \\
\hline Outcomes & \multicolumn{2}{|c|}{$\begin{array}{l}\text { Abstinence at } 12 \text { months, sustained at } 3 \text { months' and } 6 \text { months' follow-up } \\
\text { Validation: none }\end{array}$} \\
\hline Notes & \multicolumn{2}{|c|}{$\begin{array}{l}\text { No non-self-help control; comparison between materials } \\
\text { Results not reported by group; "no significant interactions or main effects" }\end{array}$} \\
\hline \multicolumn{3}{|l|}{ Risk of bias } \\
\hline Bias & Authors' judgement & Support for judgement \\
\hline $\begin{array}{l}\text { Random sequence genera- } \\
\text { tion (selection bias) }\end{array}$ & Unclear risk & Randomised; stratified by community; method not described \\
\hline $\begin{array}{l}\text { Allocation concealment } \\
\text { (selection bias) }\end{array}$ & Low risk & Centralised sequential envelopes \\
\hline $\begin{array}{l}\text { Blinding (performance } \\
\text { bias and detection bias) } \\
\text { All outcomes }\end{array}$ & Low risk & $\begin{array}{l}\text { Self-reported outcomes from participants not blinded to treatment condition, } \\
\text { but no difference in personal contact between intervention arms, so differen- } \\
\text { tial misreport judged unlikely }\end{array}$ \\
\hline $\begin{array}{l}\text { Incomplete outcome data } \\
\text { (attrition bias) } \\
\text { All outcomes }\end{array}$ & Low risk & $\begin{array}{l}\text { "Collapsing across telephone counselling groups, significantly more partic- } \\
\text { ipants receiving print only were available for follow-up at } 12 \text { months ( } 73 \%) \\
\text { than those receiving telephone counselling ( } 62 \%) \text {. Those not available for fol- } \\
\text { low-up were considered smokers for the intention-to-treat analyses" }\end{array}$ \\
\hline
\end{tabular}

\section{Strecher 2005}

\begin{tabular}{ll}
\hline Methods & $\begin{array}{l}\text { Setting: community, USA } \\
\text { Recruitment: telephone callers to NCI Cancer Information Service, interested in quitting }\end{array}$ \\
\hline Participants & 1978 smokers; $70 \%$ female, average age 41 years, $46 \%$ smoked > pack/d, FTND 5.9 \\
\hline Interventions & All participants received approx 15 minutes of telecounselling \\
\hline
\end{tabular}

Print-based self-help interventions for smoking cessation (Review) 
Control - single untailored 24-page booklet (Clearing the Air)

Intervention 1 - single 8-page tailored booklet, addressing motives and barriers cited by smoker

Intervention 2 - single untailored 24-page booklet (Clearing the Air); multiple tailored materials (book-

let, 2 newsletters, letter) at 5 months, 8 months, 12 months; tailored on baseline data

Intervention 3 - single untailored 24-page booklet (Clearing the Air); multiple re-tailored materials

(same components and schedule as Intervention 2; used data from 5-month follow up for re-tailoring)

\begin{tabular}{ll}
\hline Outcomes & $\begin{array}{l}\text { Abstinence at } 12 \text { months (7-day point prevalence, but had also reported abstinence at } 5 \text { months' fol- } \\
\text { low-up) } \\
\text { Validation: none }\end{array}$ \\
\hline Notes & To derive numbers quit, assumed equal numbers in each condition \\
& 2 plus 3 plus 4 vs 1 in tailored vs untailored \\
& Slightly more evidence of effect when multiple compared to single (3 plus 4 vs 1 plus 2 ), and also for re- \\
& tailored materials amongst subgroup who were quit at 5 months
\end{tabular}

\section{Risk of bias}

\begin{tabular}{|c|c|c|}
\hline Bias & Authors' judgement & Support for judgement \\
\hline $\begin{array}{l}\text { Random sequence genera- } \\
\text { tion (selection bias) }\end{array}$ & Unclear risk & Randomised; method not described \\
\hline $\begin{array}{l}\text { Allocation concealment } \\
\text { (selection bias) }\end{array}$ & Unclear risk & No details given \\
\hline $\begin{array}{l}\text { Blinding (performance } \\
\text { bias and detection bias) } \\
\text { All outcomes }\end{array}$ & Low risk & $\begin{array}{l}\text { Although no biochemical validation, all participants received same telecoun- } \\
\text { selling and were unaware of other treatment conditions, so risk judged to be } \\
\text { low }\end{array}$ \\
\hline $\begin{array}{l}\text { Incomplete outcome data } \\
\text { (attrition bias) } \\
\text { All outcomes }\end{array}$ & Low risk & $\begin{array}{l}\text { Only respondents at } 5 \text { months eligible for } 12 \text { months' follow-up } \\
56 \% \text { loss at } 12 \text { months (but includes those smoking at } 5 \text { months); no difference } \\
\text { by condition } \\
\text { Losses included as smokers }\end{array}$ \\
\hline
\end{tabular}

Sutton 2007

Setting: community, UK
Recruitment: callers to UK Quitline (smokers planning to quit in next 30 days or who quit in last 14
days)

\begin{tabular}{|c|c|}
\hline Participants & 1506 including 344 (23\%) recent quitters; 66\% female, average age 38, average cpd 21 \\
\hline Interventions & $\begin{array}{l}\text { All participants received telephone counselling and Quit information pack } \\
\text { - Standard letter } \\
\text { - Tailored 3-page letter (based on social-cognitive theory and perspectives on change model. Aimed } \\
\text { to encourage and support smokers. Medium- or high-dependence smokers advised to talk to their GP } \\
\text { about cessation products) }\end{array}$ \\
\hline
\end{tabular}

\begin{tabular}{ll}
\hline Outcomes & $\begin{array}{l}\text { Abstinence at } 6 \text { months; self-reported as sustained for } 3 \text { months } \\
\text { Validation: none }\end{array}$
\end{tabular}


Sutton 2007 (Continued)

Notes

Tailoring; subgroup of baseline smokers showed larger effect of intervention, but effect was still not significant

\section{Risk of bias}

\begin{tabular}{lll}
\hline Bias & Authors' judgement & Support for judgement \\
\hline $\begin{array}{l}\text { Random sequence genera- } \\
\text { tion (selection bias) }\end{array}$ & Low risk & $\begin{array}{l}\text { "Randomization was effected by dividing days randomly within each of a se- } \\
\text { ries of consecutive 56-day blocks into two equal sets, with allocation to group } \\
\text { depending on which day the participant called the Quitline" }\end{array}$ \\
\hline $\begin{array}{l}\text { Allocation concealment } \\
\text { (selection bias) }\end{array}$ & Low risk & $\begin{array}{l}\text { "Randomization was carried out by a member of the research team who had } \\
\text { no direct contact with the counsellors or the participants. Counsellors were } \\
\text { unaware of which condition the participant was allocated to and would have } \\
\text { remained blind unless the participant had happened to mention during a sub- } \\
\text { sequent telephone conversation that they had or had not received a tailored } \\
\text { letter" }\end{array}$ \\
\hline $\begin{array}{l}\text { Blinding (performance } \\
\text { bias and detection bias) }\end{array}$ & Low risk & $\begin{array}{l}\text { Although no biochemical validation, participants received same telephone } \\
\text { counselling and one-off written material, so risk of differential misreport } \\
\text { judged to be low }\end{array}$ \\
$\begin{array}{l}\text { Incomplete outcome data } \\
\begin{array}{l}\text { (attrition bias) } \\
\text { All outcomes }\end{array}\end{array}$ & Low risk & $\begin{array}{l}\text { Loss to follow-up non-significantly higher in control (24.4\%) than in interven- } \\
\text { tion (20.8\%) }\end{array}$ \\
\end{tabular}

Sykes 2001

\begin{tabular}{ll}
\hline Methods & $\begin{array}{l}\text { Setting: cessation clinic, UK } \\
\text { Recruitment: community volunteers interested in quitting }\end{array}$ \\
\hline Participants & $\begin{array}{l}260 \text { smokers, high proportion low socioeconomic status; } 64 \% \text { female, average age not stated, average } \\
\text { cpd } 25\end{array}$ \\
\hline Interventions & $\begin{array}{l}\cdot \text { Quit for Life - cognitive-behavioural manual, audiotape; gradual reduction pre-quit day; stresses psy- } \\
\text { chological addiction } \\
\text { Stopping Smoking Made Easier - leaflet, SoC-based; abrupt quit }\end{array}$ \\
\hline Outcomes & $\begin{array}{l}\text { Abstinence at } 12 \text { months (Sykes 2001 reports } 6 \text { months) } \\
\text { Validation: CO <9 ppm }\end{array}$ \\
\hline Notes & $\begin{array}{l}\text { Comparison between self-help materials; does not contribute to MA } \\
1-\text {-year data from Marks } 2002\end{array}$ \\
\hline
\end{tabular}

\section{Risk of bias}

\begin{tabular}{lll}
\hline Bias & Authors' judgement & Support for judgement \\
\hline $\begin{array}{l}\text { Random sequence genera- } \\
\text { tion (selection bias) }\end{array}$ & Unclear risk & Cluster-randomised by orientation group attended; method not described \\
\hline $\begin{array}{l}\text { Allocation concealment } \\
\text { (selection bias) }\end{array}$ & Unclear risk & $\begin{array}{l}\text { Although potential for selection bias, "the receptionist was unaware of which } \\
\text { intervention each group of participants would receive" }\end{array}$ \\
\hline
\end{tabular}


Sykes 2001 (Continued)
Blinding (performance
Low risk
Biochemical validation; similar intensity of interventions

bias and detection bias)

All outcomes

Incomplete outcome data Low risk $\quad 15 \%$ loss to follow-up at 1 year; similar across groups
(attrition bias)
All outcomes

All outcomes

\section{Thompson 1988}

\begin{tabular}{ll}
\hline Methods & $\begin{array}{l}\text { Setting: HMO, USA } \\
\text { Recruitment: consecutive attenders (unselected) }\end{array}$ \\
\hline Participants & 379 smokers (in relevant arms); average cpd not stated, $68 \%$ smoked >15 cpd \\
\hline Interventions & Complete factorial design of 3 interventions \\
& A - Physician advice - structured and interactive, 3 to 5 minutes \\
& B - Self-help materials (NCI Calling It Quits and Why Do You Smoke?; and a personalised follow-up letter) \\
C - Referral to group cessation classes & Control - brief advice only
\end{tabular}

\begin{tabular}{ll}
\hline Outcomes & $\begin{array}{l}\text { Abstinence at } 8 \text { months to } 9 \text { months by telephone survey } \\
\text { Validation: none }\end{array}$ \\
\hline Notes & A plus B and B vs A and Control in self-help plus advice vs advice only
\end{tabular}

Risk of bias

\begin{tabular}{lll}
\hline Bias & Authors' judgement & Support for judgement \\
\hline $\begin{array}{l}\text { Random sequence genera- } \\
\text { tion (selection bias) }\end{array}$ & Unclear risk & $\begin{array}{l}\text { "physician used a randomized folder placed in the patient chart"; unclear } \\
\text { when and how randomisation schedule was generated }\end{array}$ \\
\hline $\begin{array}{l}\text { Allocation concealment } \\
\text { (selection bias) }\end{array}$ & Unclear risk & $\begin{array}{l}\text { Participants enrolled before visiting physician, so selection bias by physician } \\
\text { was avoided }\end{array}$ \\
\hline $\begin{array}{l}\text { Blinding (performance } \\
\text { bias and detection bias) } \\
\text { All outcomes }\end{array}$ & Low risk & $\begin{array}{l}\text { Although no biochemical validation, participants were never aware that smok- } \\
\text { ing cessation was the study target, so risk of performance bias and differential } \\
\text { misreport were judged to be low }\end{array}$ \\
\hline $\begin{array}{l}\text { Incomplete outcome data } \\
\text { (attrition bias) } \\
\text { All outcomes }\end{array}$ & Unclear risk & $8 \%$ lost to follow-up, but not clear by what arm; not included in final analyses \\
\hline
\end{tabular}

van der Aalst 2012

\begin{tabular}{ll}
\hline Methods & Setting: community, Belgium and the Netherlands \\
& $\begin{array}{l}\text { Recruitment: subgroup of participants enrolled in lung cancer screening trial; identified via population } \\
\text { registry }\end{array}$ \\
\hline Participants & $\begin{array}{l}1284 \text { currently smoking male participants of lung cancer screening trial, } 50 \text { to } 75 \text { years old, smokers of }> \\
15 \mathrm{cpd} \text { for }>25 \text { years or }>10 \mathrm{cpd} \text { for }>30 \text { years }\end{array}$
\end{tabular}


van der Aalst 2012 (Continued)

$100 \%$ male, average age 57 , average cpd $18,55 \%$ not planning to quit within 6 months

\begin{tabular}{ll}
\hline Interventions & $\begin{array}{l}\cdot \text { Computer-tailored smoking cessation advice via mail (one-off), sent only to participants who com- } \\
\text { pleted questionnaire after randomisation }\end{array}$ \\
\hline Outcomes & Continuous abstinence at 2 years (prolonged; point prevalence also reported) \\
Validation: none & Participants had to return questionnaire before receiving tailored brochure - only $23 \%$ did so (147/642) \\
In this subset, quit rates were slightly higher (14.3\% prolonged as compared to $12.5 \%$ in total interven- \\
tion group) but were still less than in control group and no significant difference
\end{tabular}

\section{Risk of bias}

\begin{tabular}{lll}
\hline Bias & Authors' judgement & Support for judgement \\
\hline $\begin{array}{l}\text { Random sequence genera- } \\
\text { tion (selection bias) }\end{array}$ & Unclear risk & Not specified \\
\hline $\begin{array}{l}\text { Allocation concealment } \\
\text { (selection bias) }\end{array}$ & Unclear risk & Not specified \\
\hline $\begin{array}{l}\text { Blinding (performance } \\
\text { bias and detection bias) } \\
\text { All outcomes }\end{array}$ & Low risk & Not blinded, but at assessment, majority of participants were unaware of \\
& & which they had been assigned to; differential misreport judged to be unlikely \\
\hline $\begin{array}{l}\text { Incomplete outcome data } \\
\text { (attrition bias) }\end{array}$ & Low risk & $84 \%$ intervention and 85\% control followed up at 2 years \\
\hline \begin{tabular}{l} 
All outcomes \\
\hline
\end{tabular} & & \\
\hline
\end{tabular}

Velicer 1999

\begin{tabular}{ll}
\hline Methods & $\begin{array}{l}\text { Setting: managed care organisation, USA } \\
\text { Recruitment: smokers identified by survey of members; } 85 \% \text { recruited to study }\end{array}$ \\
\hline Participants & 2882 smokers in a managed care organisation; average age 38 years, average cpd 20 \\
\hline Interventions & $\begin{array}{l}\text { - Interactive expert system - generated } 2 \text { to 4-page reports based on SoC model and stage-based man- } \\
\text { uals; } 4 \text { different levels of contact - } 1,2 \text {, 3, and } 4 \text { occasions at 3-month intervals } \\
\cdot \text { Stage-based manuals only; same } 4 \text { levels of contact }\end{array}$ \\
\hline Outcomes & $\begin{array}{l}\text { Abstinence at } 18 \text { months, sustained for } 6 \text { months (other measures of abstinence also reported) } \\
\text { Validation: none }\end{array}$ \\
\hline Notes & $\begin{array}{l}1 \text { vs 2, tailoring } \\
\text { No evidence of a dose response to the number of contacts in either condition } \\
\text { Expert system conditions were better than stage-based at each contact level, so these were collapsed } \\
\text { in meta-analysis }\end{array}$ \\
\hline
\end{tabular}

\section{Risk of bias}

Print-based self-help interventions for smoking cessation (Review) 
Velicer 1999 (Continued)

\begin{tabular}{lll} 
Bias & Authors' judgement & Support for judgement \\
\hline $\begin{array}{l}\text { Random sequence genera- } \\
\text { tion (selection bias) }\end{array}$ & Unclear risk & Randomised; method not described \\
\hline $\begin{array}{l}\text { Allocation concealment } \\
\text { (selection bias) }\end{array}$ & Unclear risk & No details given \\
\hline $\begin{array}{l}\text { Blinding (performance } \\
\text { bias and detection bias) }\end{array}$ & Low risk & Not blinded or biochemically validated, but given similar intensity of both con- \\
All outcomes & ditions; performance bias and differential misreport judged to be unlikely \\
\hline $\begin{array}{l}\text { Incomplete outcome data } \\
\text { (attrition bias) } \\
\text { All outcomes }\end{array}$ & Low risk & $\begin{array}{l}\text { Study authors report numbers refusing follow-up and numbers not reached } \\
\text { Size and significance of results are sensitive to whether or not those lost to fol- } \\
\text { low-up or refusing to respond are included in the denominator as continued } \\
\text { smokers }\end{array}$ \\
\hline
\end{tabular}

Velicer 2006

\begin{tabular}{ll}
\hline Methods & Setting: community, USA \\
& Recruitment: proactive approach to smokers at Veterans Administration Medical Center
\end{tabular}

\begin{tabular}{ll}
\hline Participants & $\begin{array}{l}2054 \text { smokers (1031 in relevant arms); 23\% female, average age } 51 \text { years, 40\% pre-contemplators, } 40 \% \\
\text { contemplators, } 20 \% \text { preparers }\end{array}$ \\
\hline Interventions & - Stage-based self-help manuals; participants sent manual for current stage and for next stage on \\
- As first bullet above plus 6 weeks nicotine patch if in appropriate stage; reassessed for NRT eligibility \\
at 6 months and 10 months \\
- As second bullet plus 1 expert system feedback report (see Prochaska trials) \\
- As third bullet plus regular automated telephone counselling
\end{tabular}

\begin{tabular}{ll}
\hline Outcomes & $\begin{array}{l}\text { Abstinence at } 30 \text { months; sustained for } 6 \text { months } \\
\text { Validation: none }\end{array}$
\end{tabular}

Validation: none

Notes 3 vs 2 for tailored adjunct to targeted self-help

In NRT groups, 350 (67\%) received NRT at baseline and 448 (86\%) received NRT at some point

\begin{tabular}{lll}
\hline Risk of bias & & \\
\hline Bias & Authors' judgement & Support for judgement \\
\hline $\begin{array}{l}\text { Random sequence genera- } \\
\text { tion (selection bias) }\end{array}$ & Low risk & Computer-based random number generator \\
\hline $\begin{array}{l}\text { Allocation concealment } \\
\text { (selection bias) }\end{array}$ & Low risk & Allocation done after completion of survey \\
& $\begin{array}{l}\text { Randomised participants who did not return consent form were excluded from } \\
\text { further analyses }\end{array}$ \\
\hline
\end{tabular}


Velicer 2006 (Continued)

\begin{tabular}{lll}
$\begin{array}{l}\text { Blinding (performance } \\
\text { bias and detection bias) } \\
\text { All outcomes }\end{array}$ & Low risk & $\begin{array}{l}\text { Self-reported outcomes from participants not blinded to treatment condition, } \\
\text { but intensity did not differ substantially by condition, so differential misreport } \\
\text { judged to be unlikely }\end{array}$ \\
\hline $\begin{array}{l}\text { Incomplete outcome data } \\
\text { (attrition bias) }\end{array}$ & Low risk & $\begin{array}{l}39 \% \text { lost including } 8 \% \text { refused by } 30 \text { months; no significant differences be- } \\
\text { tween groups }\end{array}$ \\
& $\begin{array}{l}\text { Different treatments of missing data reported not to have altered pattern of re- } \\
\text { sults }\end{array}$
\end{tabular}

Webb 2013

$\begin{array}{ll}\text { Methods } & \text { Setting: community, USA } \\ \text { Recruitment: community volunteers }\end{array}$

Participants 424 current smokers of $\geq 5$ cpd, $57 \%$ female, average age 42 years, average cpd 19.7

Interventions Both groups received 2 priming phone calls explaining benefits of intervention and encouraging use of materials. In intervention, priming call explicitly stated materials were tailored

- 4 self-help booklets with placebo tailoring, covering cigarette smoking, cessation, and relapse prevention, based on cognitive-behavioural techniques

- 4 standard self-help booklets covering same materials

Outcomes 1 month sustained abstinence at 6 months

Validation: $\mathrm{CO} \leq 8 \mathrm{ppm}$ for locals

$$
\text { Notes }
$$

\section{Risk of bias}

\begin{tabular}{lll}
\hline Bias & Authors' judgement & Support for judgement \\
\hline $\begin{array}{l}\text { Random sequence genera- } \\
\text { tion (selection bias) }\end{array}$ & Unclear risk & Not specified \\
\hline $\begin{array}{l}\text { Allocation concealment } \\
\text { (selection bias) }\end{array}$ & Unclear risk & Not specified \\
\hline $\begin{array}{l}\text { Blinding (performance } \\
\text { bias and detection bias) } \\
\text { All outcomes }\end{array}$ & Low risk & Biochemical validation used; interventions of similar intensities \\
\hline $\begin{array}{l}\text { Incomplete outcome data } \\
\text { (attrition bias) }\end{array}$ & Low risk & $29 \%$ lost in intervention group, 25\% lost in control group \\
All outcomes & \\
\hline
\end{tabular}

\section{Willemsen 2006}

Methods Setting: community, Netherlands


Willemsen 2006 (Continued)

Recruitment: smokers identified from a market research database; willing to participate in evaluation of an 'information aid'

\begin{tabular}{ll}
\hline Participants & $\begin{array}{l}1014 \text { smokers 'intending to quit'; 46\% female, modal age } 35 \text { to } 44 \text { years, modal cpd 18 to 22, 86\% daily } \\
\text { smokers }\end{array}$ \\
\hline Interventions & $\begin{array}{l}\text { - Mailed Decision Aid: Starter's Kit, including information about all major available treatment methods, } \\
\text { classified into known effective and unknown; samples of materials and information on how to obtain } \\
\text { them; video with descriptions of quitting experiences } \\
\cdot \text { No intervention }\end{array}$ \\
\hline Outcomes & $\begin{array}{l}\text { Sustained abstinence at } 6 \text { months (quit for longer than } 4 \text { months) } \\
\text { Validation: none }\end{array}$ \\
\hline Notes & $\begin{array}{l}\text { Self-help vs control; aid had no effect on prolonged abstinence outcome used in meta-analysis but did } \\
\text { have an effect on point prevalence abstinence }\end{array}$ \\
& $\begin{array}{l}\text { Aim of intervention was to increase use of efficacious aids, but it had no effect } \\
\text { Study authors note that aid "did not contain any concrete self-help information that the smokers might } \\
\text { have put into practice" }\end{array}$ \\
\hline
\end{tabular}

\section{Risk of bias}

\begin{tabular}{lll}
\hline Bias & Authors' judgement & Support for judgement \\
\hline $\begin{array}{l}\text { Random sequence genera- } \\
\text { tion (selection bias) }\end{array}$ & Unclear risk & Randomised; method not stated \\
\hline $\begin{array}{l}\text { Allocation concealment } \\
\text { (selection bias) }\end{array}$ & Unclear risk & No details given \\
\hline $\begin{array}{l}\text { Blinding (performance } \\
\text { bias and detection bias) } \\
\text { All outcomes }\end{array}$ & High risk & $\begin{array}{l}\text { Participants in control group aware that it was a trial of self-help materials; } \\
\text { never received materials, which could have artificially lowered control group } \\
\text { quit rate }\end{array}$ \\
\hline $\begin{array}{l}\text { Incomplete outcome data } \\
\text { (attrition bias) } \\
\text { All outcomes }\end{array}$ & Low risk & $\begin{array}{l}11.8 \% \text { lost at } 6 \text { months; intervention participants more likely to be missing at 2 } \\
\text { weeks' but not at } 6 \text { months' follow-up }\end{array}$ \\
\hline
\end{tabular}

4As: Ask, Advise, Assist, Arrange.

ALA FfS: American Lung Association Freedom from Smoking programme.

CCS: Canadian Cancer Society.

$\mathrm{Cl}$ : confidence interval.

CO: carbon monoxide.

cpd: cigarettes per day.

$\mathrm{FEV}_{1}$ : forced expiratory volume in one second.

FTND: Fagerstrom Test for Nicotine Dependence.

GP: general practitioner.

HEA: Health Education Authority.

HMO: health maintenance organisation.

ITT: intention to treat.

MA: meta-analysis.

$\mathrm{NCl}$ : National Cancer Institute.

NG: nicotine gum.

NRT: nicotine replacement therapy.

OR: odds ratio.

ppm: parts per million. 
RR: risk ratio.

SES: socioeconomic status.

SoC: stage of change.

TTM: transtheoretical model.

TTQ: time to quit.

VA: Veterans Administration.

Characteristics of excluded studies [ordered by study ID]

\begin{tabular}{|c|c|}
\hline Study & Reason for exclusion \\
\hline Ainsworth 2013 & $\begin{array}{l}\text { Not a self-help intervention; intervention print-based, but aimed at faith leaders to effect change in } \\
\text { their communities }\end{array}$ \\
\hline Armitage 2008a & Follow-up only 2 months \\
\hline Armitage 2008b & Follow-up only 1 month; intervention borderline for inclusion \\
\hline Arnold 2009 & Follow-up only 1 month \\
\hline Balanda 1999 & $\begin{array}{l}\text { Follow-up only } 1 \text { month after provision of } 1 \text { of } 2 \text { self-help guides to quitline callers; no differences } \\
\text { found between groups }\end{array}$ \\
\hline Bansal-Travers 2010 & Only 1 month's follow-up; all participants received NRT and counselling \\
\hline Barnett 2015 & Intervention group also received counselling \\
\hline Brandon 2000 & Only recent quitters recruited; included in Cochrane Review of relapse prevention (Hajek 2013) \\
\hline Brandon 2004 & Only recent quitters recruited; included in Cochrane Review of relapse prevention (Hajek 2013) \\
\hline Brandon 2012 & Relapse prevention intervention \\
\hline Brown 1992 & $\begin{array}{l}\text { Both arms received S-H materials; test of telephone counselling; included in Cochrane Review of } \\
\text { telephone counselling (Stead 2013b) }\end{array}$ \\
\hline Burling 2000 & $\begin{array}{l}\text { Evaluated an internet-based intervention; previously included in review but not in meta-analysis; } \\
\text { falls within scope of separate Cochrane protocol (Koshy 2008) }\end{array}$ \\
\hline Carré 2008 & Short follow-up; not primarily directed at cessation \\
\hline Conway 2004 & Intervention targeted at relapse prevention (see Edwards 1999) \\
\hline Curry 1988 & $\begin{array}{l}\text { Compares self-help materials with a relapse prevention approach vs abstinence-based approach; } \\
\text { now included in relapse prevention review (Hajek 2013) }\end{array}$ \\
\hline Dijkstra 1998b & $\begin{array}{l}\text { Follow-up only } 4 \text { months ( } 6 \text { weeks from last contact for multiple tailored letters condition) } \\
\text { Study compared combinations of tailored letters and a self-help guide for a population of smokers } \\
\text { not planning to quit }\end{array}$ \\
\hline Dijkstra 2001 & Follow-up only 3 months; compares different types of information in self-help materials \\
\hline Dijkstra 2005 & $\begin{array}{l}\text { Not a structured S-H intervention; outcome is "quitting activity" at } 4 \text { months. Participants were } \\
\text { students recruited to evaluate smoking cessation messages }\end{array}$ \\
\hline Dijkstra 2006 & Outcome is change in stage - not abstinence \\
\hline
\end{tabular}




\begin{tabular}{|c|c|}
\hline Study & Reason for exclusion \\
\hline Dijkstra 2009 & Field study testing function of disengagement beliefs; numbers abstinent not reported \\
\hline Edwards 1999 & $\begin{array}{l}\text { Intervention directed at relapse prevention in female naval recruits required to quit smoking dur- } \\
\text { ing basic training; included in review of relapse prevention interventions (Hajek 2013) }\end{array}$ \\
\hline Emmons 2013 & Does not test self-help; self-help served as control for more intensive intervention \\
\hline Etter 2007 & $\begin{array}{l}\text { Intervention provided information about additives in cigarettes; focus on motivating rather than } \\
\text { assisting quitting }\end{array}$ \\
\hline Fortmann 1995 & Excluded from 2018 update because study of relapse prevention \\
\hline Garcia 2000 & $\begin{array}{l}\text { Trial of group therapy-based interventions; self-help manuals provided in addition to group thera- } \\
\text { py to test effect of therapist contact; included in Cochrane Group Therapy Review (Stead 2017) }\end{array}$ \\
\hline Gritz 1988 & No control group \\
\hline Hall 2003 & Smoking cessation not an outcome \\
\hline Jeffery 1982 & No long-term follow-up; control was a group programme \\
\hline Jeffery 1990 & $\begin{array}{l}\text { Compared the offer of a self-help programme at a nominal cost vs the same programme for a } \\
\text { USD } 60 \text { payment, refundable if successful. Rate of recruitment to the incentive programme very low } \\
\text { (9 participants, } 0.09 \% \text { of households randomly assigned to receive the incentive option) }\end{array}$ \\
\hline
\end{tabular}

\begin{tabular}{ll}
\hline Johs 2003 & No long-term follow-up \\
\hline Jordan 1999 & $\begin{array}{l}\text { Only } 3 \text { months' follow-up planned; comparison of an internet-based programme vs ALA printed } \\
\text { manuals; } 54 \text { participants }\end{array}$ \\
\hline
\end{tabular}

\begin{tabular}{ll}
\hline Killen 1990 & Excluded from 2018 update because study of relapse prevention \\
\hline Kreuter 1996 & $\begin{array}{l}\text { Intervention provided single page of cessation information for participants who were smokers } \\
(22 \%) \text { and interested in quitting; not a self-help intervention by the criteria for this review (neither } \\
\text { standard nor enhanced feedback increased quit rates over control) }\end{array}$
\end{tabular}

\begin{tabular}{ll}
\hline Kreuter 2012 & $\begin{array}{l}\text { Print materials not designed as self-help; intention to increase number of people taking up refer- } \\
\text { rals to specialist service }\end{array}$
\end{tabular}

\begin{tabular}{ll}
\hline Lenert 2004 & Not randomised; used consecutive series of participants \\
\hline Lipkus 2004 & Self-help was the control condition \\
\hline McBride 1999 & $\begin{array}{l}\text { Intervention included } 3 \text { proactive telephone calls in addition to provision of self-help materials; no } \\
\text { effect of the intervention was found }\end{array}$ \\
\hline McDonald 2003 & Unpublished study; insufficient data to include \\
\hline McDonnell 2011 & Does not test self-help; self-help served as control for more intensive intervention \\
\hline McMahon 2000 & $\begin{array}{l}\text { Tested incentives and social support as adjuncts to self-help; included in Cochrane Review of sup- } \\
\text { port (Park 2004) }\end{array}$ \\
\hline Meade 1989 & $\begin{array}{l}\text { Compared smokers' ability to understand materials written at different grade levels; cessation was } \\
\text { not an outcome }\end{array}$ \\
\hline
\end{tabular}




\begin{tabular}{|c|c|}
\hline Study & Reason for exclusion \\
\hline Moore 2002 & Participants were pregnant women \\
\hline Murphy 2005 & $\begin{array}{l}\text { Only } 3 \text { months' follow-up; marginal to classify as self-help intervention; provided information on } \\
\text { access to pharmacotherapy and cessation support }\end{array}$ \\
\hline Naughton 2012 & Does not test self-help; self-help served as control for more intensive intervention \\
\hline NCT00714467 & Experimental variable is partner support - not self-help \\
\hline NCT01566994 & No suitable control group for comparison \\
\hline O'Hara 1993 & Follow-up only 3 weeks after receipt of materials \\
\hline Ossip-Klein 1991 & $\begin{array}{l}\text { Both arms received self-help materials; test of hotline availability; included in Cochrane Review of } \\
\text { telephone counselling (Stead 2013b) }\end{array}$ \\
\hline Ossip-Klein 1997 & $\begin{array}{l}\text { Both arms received self-help materials; test of telephone counselling; included in Cochrane Review } \\
\text { of telephone counselling (Stead 2013b) }\end{array}$ \\
\hline Pallonen 1998 & $\begin{array}{l}\text { Intervention targeted for adolescents; } 2 \text { self-help computer-based interventions compared; includ- } \\
\text { ed in a Cochrane Review of cessation interventions for adolescents and young people (Fanshawe } \\
\text { 2017) }\end{array}$ \\
\hline Pederson 1981 & $\begin{array}{l}\text { Although this is described as a trial of behavioural self-help manuals, treatment conditions includ- } \\
\text { ed an introductory meeting and } 2 \text { further group meetings }\end{array}$ \\
\hline Rimer 1994 & No long-term follow-up data reported in full \\
\hline \multirow[t]{3}{*}{ Russell 1979} & $\begin{array}{l}\text { Leaflet used as an adjunct to physician advice did not meet study criteria for a structured self-help } \\
\text { intervention }\end{array}$ \\
\hline & Smokers given the leaflet were also warned that they would be followed up \\
\hline & $\begin{array}{l}\text { Study found a non-significant increase in the quit rate amongst participants who were given the } \\
\text { leaflet in addition to advice, but including it would not alter the results of the MA, which found no } \\
\text { effect of materials as an adjunct to advice }\end{array}$ \\
\hline Sallis 1986 & Only 2 months' follow-up; then wait-list control offered treatment \\
\hline Senesael 2013 & $\begin{array}{l}\text { Multiple risk factor intervention recruiting only } 7 \text { smokers; unclear if smoking intervention met in- } \\
\text { clusion criteria }\end{array}$ \\
\hline Shi 2013 & Does not test self-help; self-help served as control for more intensive intervention \\
\hline Shiffman 2000 & $\begin{array}{l}\text { Only } 6 \text { weeks' follow-up; tested materials tailored to individual smokers, in addition to nicotine } \\
\text { gum; compared to gum and standard written materials }\end{array}$ \\
\hline Shiffman 2001 & $\begin{array}{l}\text { Only } 6 \text { weeks' follow-up; tested materials tailored to individual smokers, in addition to nicotine } \\
\text { patches; compared to patches and standard written materials }\end{array}$ \\
\hline Sims 2013 & Does not test self-help; self-help served as control for more intensive intervention \\
\hline Song 2012 & Relapse prevention intervention \\
\hline Stanczyk 2013 & Web-based intervention \\
\hline Strecher 1994 & Did not meet review criteria for self-help materials \\
\hline
\end{tabular}




\begin{tabular}{|c|c|}
\hline Study & Reason for exclusion \\
\hline & $\begin{array}{l}\text { Compared health letters tailored to individual recipient's smoking behaviour vs no intervention } \\
\text { (Study 2) or a standardised health letter from a physician (an adaptation of NCI Quit for Good pam- } \\
\text { phlet addressing general benefits of and barriers to quitting smoking) (Study 1) }\end{array}$ \\
\hline & Study 1 had less than 6 months' follow-up \\
\hline Strecher 2000 & Participants were pregnant women \\
\hline Strecher 2005b & Short follow-up \\
\hline Strecher 2008 & Did not meet review criteria for self-help materials; Web-based programme \\
\hline Te Poel 2009 & Web-based intervention \\
\hline Travis 2004 & Short follow-up; self-help was an adjunct to telephone counselling \\
\hline Travis 2009 & Only 3 months' follow-up \\
\hline Ussher 2011 & Uncontrolled evaluation \\
\hline Webb 2005 & Smoking status not a measured outcome \\
\hline Webb 2007 & Smoking status not a measured outcome \\
\hline Webb 2008 & Only 3 months' follow-up \\
\hline Webb 2009 & Only 3 months' follow-up \\
\hline Webb 2010 & $\begin{array}{l}\text { Outcomes included risk perceptions, readiness to quit smoking, and smoking-related knowledge - } \\
\text { not smoking cessation }\end{array}$ \\
\hline Weissfeld 1991 & 'Self-help' condition received several individual counselling sessions \\
\hline Wetter 2011 & All groups received multiple group counselling sessions \\
\hline Willemsen 1995 & Not a randomised trial \\
\hline Windsor 1989 & All groups received the same self-help intervention; differed on additional support or incentives \\
\hline Zhu 1996 & $\begin{array}{l}\text { All arms received self-help materials; test of telephone counselling; included in Cochrane Review of } \\
\text { telephone counselling (Stead 2013b) }\end{array}$ \\
\hline
\end{tabular}

ALA: American Lung Association.

MA: meta-analysis.

$\mathrm{NCl}$ : National Cancer Institute.

NRT: nicotine replacement therapy.

Characteristics of studies awaiting assessment [ordered by study ID]

\section{Campos 2014}

\begin{tabular}{ll}
\hline Methods & Prospective randomised study \\
\hline Participants & 90 people who smoke hospitalised in the University Hospital Antonio Pedro, Brazil \\
& $61.1 \%$ male, average age $51.1 \pm 12.2$ years \\
\hline
\end{tabular}


Campos 2014 (Continued)

Interventions

- Brief intervention $(n=45)$

- Intensive intervention with presentation of an educational video produced by researchers $(n=45)$

Outcomes Smoking abstinence assessed by telephone in first, third, and sixth month after discharge and con-
firmed by carbon monoxide measurement

Notes Could not find contact details of study author team

Oh 2013

\begin{tabular}{ll}
\hline Methods & Prospective randomised controlled study \\
\hline Participants & 58 active smokers who presented to an academic otolaryngology clinic \\
\hline Interventions & $\cdot$ Received a free copy of the book, Allen Carr's The Easy Way to Stop Smoking \\
& Received only the name of the book and author \\
& Both cohorts received physician-directed cessation counselling \\
\hline Outcomes & $\begin{array}{l}\text { Follow-up phone calls were conducted at } 2 \text { weeks and } 6 \text { months to assess smoking status, whether } \\
\text { control group participants bought the book, and how many pages of the book were read }\end{array}$ \\
\hline Notes & Study authors contacted for further details but no response yet \\
\hline
\end{tabular}

Pereira 2017

\begin{tabular}{ll}
\hline Methods & Prospective randomised study \\
\hline Participants & Hypertensive, diabetic, and chronic renal patients with high cardiovascular risk \\
& Sixty-six people who smoke, $64.7 \%$ female \\
\hline Interventions & $\cdot$ Intervention group - using an interactive and educational video about smoking \\
& $\cdot$ Control group - using a basic approach to smoking \\
\hline Outcomes & Unclear if smoking abstinence was reported \\
\hline Notes & Could not find contact details of study author team \\
\hline
\end{tabular}

\section{Characteristics of ongoing studies [ordered by study ID]}

\section{JPRN-UMIN000008750}

\begin{tabular}{ll}
\hline Trial name or title & $\begin{array}{l}\text { A randomized study of bibliotherapy for smoking cessation with and without focusing on cognitive } \\
\text { elements }\end{array}$ \\
\hline Methods & Randomised controlled trial \\
\hline Participants & People who smoke (target sample size: 1000) \\
\hline
\end{tabular}

Print-based self-help interventions for smoking cessation (Review)

Copyright $\odot 2019$ The Cochrane Collaboration. Published by John Wiley \& Sons, Ltd. 


\section{JPRN-UMIN000008750 (Continued)}

Interventions $\quad$ Provide 1 bibliotherapy booklet focussed on cognitive elements

- Provide 1 conventional bibliotherapy booklet

\begin{tabular}{ll}
\hline Outcomes & Smoking status followed up at 1 year \\
\hline Starting date & $23 / 08 / 2012$ \\
\hline Contact information & Takeshi Isomur; atakeshiisomura@gmail.com \\
\hline Notes & Funding: self-funded \\
\hline
\end{tabular}

\section{NCT01544010}

\begin{tabular}{ll}
\hline Trial name or title & Optimal TTM tailoring for population cessation (STAR) \\
\hline Methods & Randomised controlled trial \\
\hline Participants & 3006 people who smoke \\
\hline Interventions & $\cdot$ Assessment only control group \\
& $\cdot$ Stage-tailored manual \\
& $\cdot$ Stage-tailored feedback report \\
& $\cdot$ Moderate TTM-tailored feedback report \\
& $\cdot$ Full TTM-tailored feedback report \\
& $\cdot$ Enhanced TTM+Addiction-tailored feedback report \\
\hline Outcomes & Self-reported smoking abstinence at 24 months \\
\hline Starting date & February 2009 \\
\hline Contact information & Colleen A. Redding; credding@uri.edu \\
\hline Sotes & Study presumed complete. Study author team contacted for results, but no response received \\
\hline
\end{tabular}

\section{NCT02276664}

\begin{tabular}{ll}
\hline Trial name or title & Capitalizing on a teachable moment to promote smoking cessation \\
\hline Methods & Randomised controlled trial \\
\hline Participants & People who have smoked at least 1 cigarette over the past week \\
\hline Interventions & $\cdot$ Self-help intervention \\
& $\cdot$ Usual care \\
\hline Outcomes & Self-reported 7-day abstinence up to 9 months
\end{tabular}


NCT02276664 (Continued)
Starting date
$20 / 10 / 2014$

Contact information

Thomas Brandon; Thomas.Brandon@moffitt.org

Notes

NCT02416011

\begin{tabular}{ll}
\hline Trial name or title & Smoking cessation self-help for dual users of tobacco cigarettes and e-cigarettes \\
\hline Methods & Randomised controlled trial \\
\hline Participants & Adult current dual users of tobacco cigarettes and e-cigarettes \\
\hline Interventions & $\cdot$ Assessment only \\
& $\cdot$ Generic self-help \\
& $\cdot$ Targeted self-help \\
\hline Outcomes & Smoking abstinence at 24 months \\
\hline Starting date & \begin{tabular}{l} 
31/03/2015 \\
\hline Contact information
\end{tabular} \\
\hline Notes & $\begin{array}{l}\text { Thomas Brandon; Thomas.Brandon@moffitt.org } \\
\text { of Health (R01DA037961) }\end{array}$ \\
\hline
\end{tabular}

\section{NCT02611076}

\begin{tabular}{ll}
\hline Trial name or title & Smoking-cessation: a Spanish-language clinical trial \\
\hline Methods & Randomised controlled trial \\
\hline Participants & $\begin{array}{l}\text { People who currently smoke and are monolingual Spanish, or bilingual Spanish-English, and prefer } \\
\text { receiving educational health materials in Spanish }\end{array}$ \\
\hline Interventions & $\begin{array}{l}\cdot \text { Stop Smoking for Good Intervention in Spanish (10 booklets distributed over 18 months, plus addi- } \\
\text { tional monthly contacts via 9 supportive pamphlets) } \\
\text { Usual care }\end{array}$ \\
\hline Outcomes & Smoking cessation rates based on 7-day point prevalence abstinence at 24 months \\
\hline Starting date & 15/10/2015 \\
\hline Contact information & Vani N. Simmons; Vani.simmons@moffitt.org \\
\hline Notes &
\end{tabular}


NCT02945787

\begin{tabular}{ll}
\hline Trial name or title & Spanish-language smoking cessation trial \\
\hline Methods & Randomised controlled trial \\
\hline Participants & $\begin{array}{l}\text { People who currently smoke and are monolingual Spanish-speaking, or bilingual Spanish-English, } \\
\text { and prefer receiving educational health materials in Spanish }\end{array}$ \\
\hline Interventions & $\cdot$ Extended self-help (Spanish-language version of the Stop Smoking for Good: 11 Stop Smoking for \\
& $\begin{array}{l}\cdot \text { Usual care } \\
\text { Outcomes }\end{array}$ \\
\hline Starting date & Smoking cessation rates based on 7-day point prevalence abstinence at 24 months \\
\hline Contact information & Thomas Brandon; Thomas.Brandon@moffitt.org \\
\hline Notes & \\
\hline
\end{tabular}

\section{NCT03064971}

\begin{tabular}{|c|c|}
\hline Trial name or title & Enhancing quitline services for African American smokers \\
\hline Methods & Randomised controlled trial \\
\hline Participants & People who currently smoke and self-identify as Black/African American \\
\hline \multirow[t]{3}{*}{ Interventions } & - Standard care plus Pathways to Freedom DVD \\
\hline & - Standard care plus standard smoking cessation DVD \\
\hline & - Standard care only \\
\hline Outcomes & Cotinine-verified 7-day point prevalence abstinence at 6 months \\
\hline Starting date & $22 / 05 / 2017$ \\
\hline Contact information & Monica Webb Hooper; monica.hooper@case.edu \\
\hline \multirow[t]{2}{*}{ Notes } & $\begin{array}{l}\text { Funding: Monica Webb Hooper, PhD, was supported by a Research Scholars Grant from the Ameri- } \\
\text { can Cancer Society (15-154-01-CPPB) }\end{array}$ \\
\hline & $\begin{array}{l}\text { Declaration of interests: one study author declares that she is employed by Alere Wellbeing and } \\
\text { has no other competing interests. Remaining study authors declare that they have no competing } \\
\text { interests }\end{array}$ \\
\hline
\end{tabular}

TTM: transtheoretical model.

\section{DATA AND ANALYSES}


Comparison 1. Non-tailored self-help vs no self-help, pooled by amount of contact

\begin{tabular}{|c|c|c|c|c|}
\hline Outcome or subgroup title & No. of studies & $\begin{array}{l}\text { No. of partici- } \\
\text { pants }\end{array}$ & Statistical method & Effect size \\
\hline $\begin{array}{l}1 \text { Neither group had face-to-face con- } \\
\text { tact (long-term abstinence) }\end{array}$ & 17 & 20264 & $\begin{array}{l}\text { Risk Ratio (M-H, Random, } \\
95 \% \mathrm{Cl})\end{array}$ & $1.05[0.92,1.20]$ \\
\hline 1.1 Control group given no materials & 11 & 13241 & $\begin{array}{l}\text { Risk Ratio (M-H, Random, } \\
95 \% \mathrm{CI})\end{array}$ & $1.19[1.03,1.37]$ \\
\hline $\begin{array}{l}1.2 \text { Control group given leaflet/pam- } \\
\text { phlet }\end{array}$ & 6 & 7023 & $\begin{array}{l}\text { Risk Ratio (M-H, Random, } \\
95 \% \mathrm{Cl})\end{array}$ & $0.87[0.71,1.07]$ \\
\hline $\begin{array}{l}2 \text { Neither group had face-to-face con- } \\
\text { tact (Becona studies only) }\end{array}$ & 2 & 924 & $\begin{array}{l}\text { Risk Ratio (M-H, Random, } \\
95 \% \mathrm{Cl})\end{array}$ & $10.91[5.03,23.66]$ \\
\hline 2.1 Control group given no materials & 2 & 924 & $\begin{array}{l}\text { Risk Ratio (M-H, Random, } \\
95 \% \mathrm{Cl} \text { ) }\end{array}$ & $10.91[5.03,23.66]$ \\
\hline $\begin{array}{l}3 \text { Both groups had face-to-face contact } \\
\text { (long-term abstinence) }\end{array}$ & 4 & 2822 & $\begin{array}{l}\text { Risk Ratio (M-H, Random, } \\
95 \% \mathrm{Cl})\end{array}$ & $1.39[1.03,1.88]$ \\
\hline 3.1 Control group given no materials & 3 & 1668 & $\begin{array}{l}\text { Risk Ratio (M-H, Random, } \\
95 \% \mathrm{Cl})\end{array}$ & $1.35[0.80,2.26]$ \\
\hline $\begin{array}{l}3.2 \text { Control group given leaflet/pam- } \\
\text { phlet }\end{array}$ & 1 & 1154 & $\begin{array}{l}\text { Risk Ratio (M-H, Random, } \\
95 \% \mathrm{Cl})\end{array}$ & $1.42[0.98,2.04]$ \\
\hline $\begin{array}{l}4 \text { Both groups had face-to-face contact } \\
\text { with advice (long-term abstinence) }\end{array}$ & 11 & 5365 & $\begin{array}{l}\text { Risk Ratio (M-H, Random, } \\
95 \% \mathrm{Cl})\end{array}$ & $0.99[0.76,1.28]$ \\
\hline 4.1 Control group given no materials & 8 & 3581 & $\begin{array}{l}\text { Risk Ratio (M-H, Random, } \\
95 \% \mathrm{Cl})\end{array}$ & $0.91[0.66,1.27]$ \\
\hline $\begin{array}{l}4.2 \text { Control group given leaflet/pam- } \\
\text { phlet }\end{array}$ & 3 & 1784 & $\begin{array}{l}\text { Risk Ratio (M-H, Random, } \\
95 \% \mathrm{Cl})\end{array}$ & $1.18[0.71,1.95]$ \\
\hline
\end{tabular}

Analysis 1.1. Comparison 1 Non-tailored self-help vs no self-help, pooled by amount of contact, Outcome 1 Neither group had face-to-face contact (long-term abstinence).

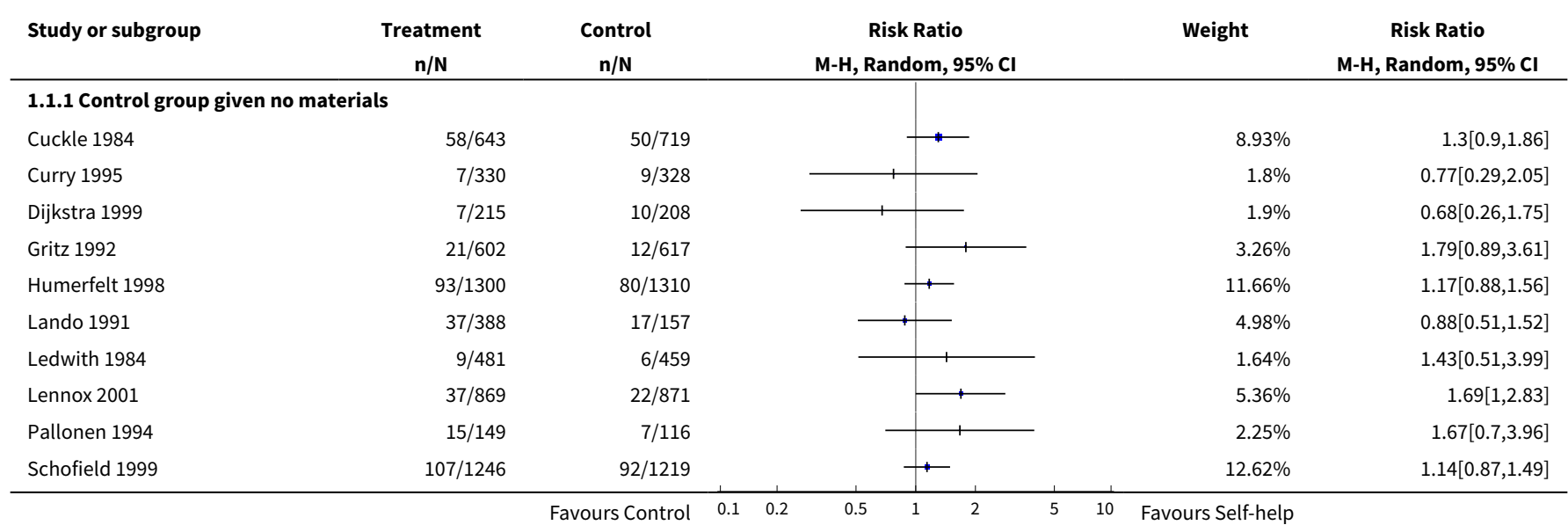




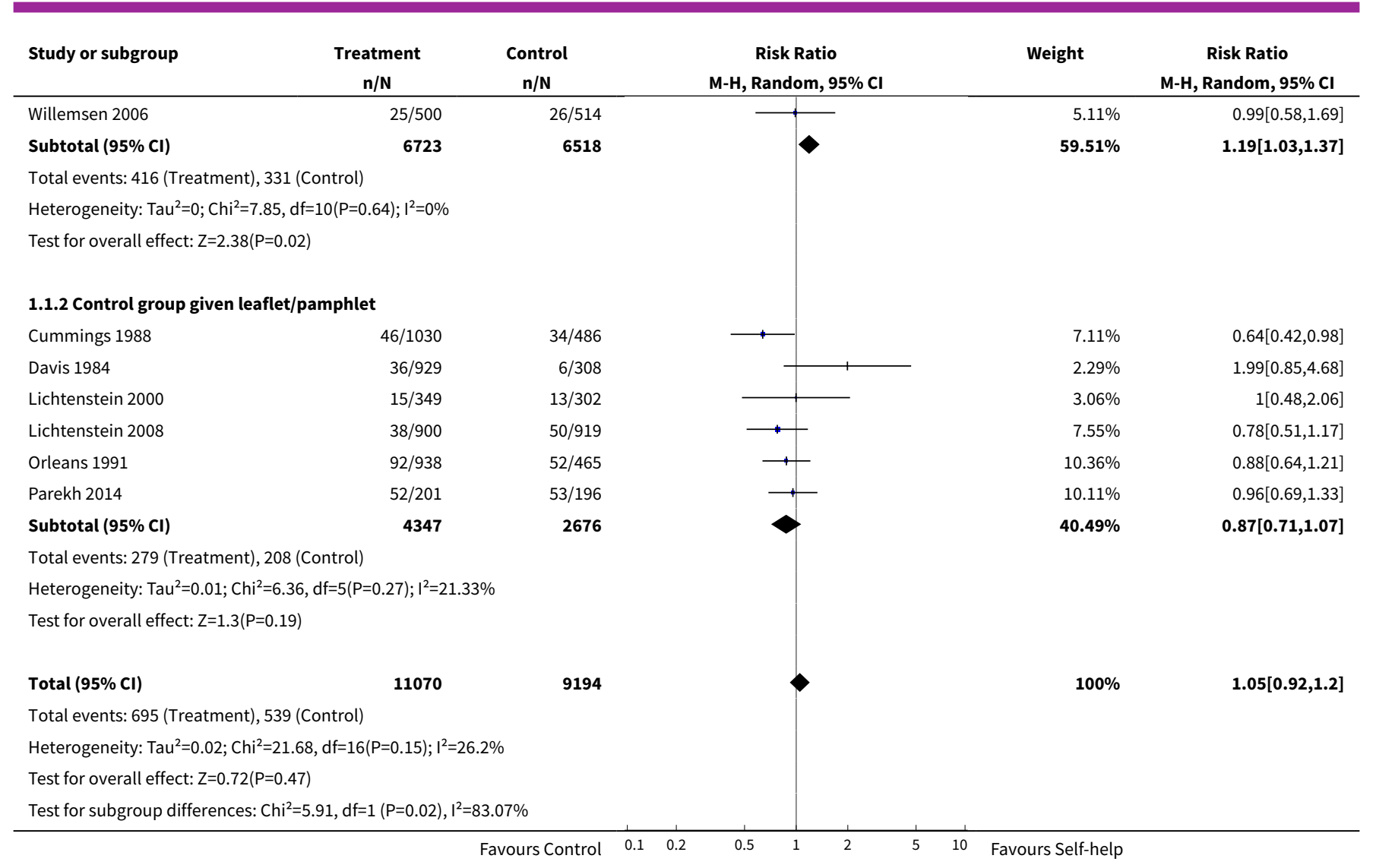

Analysis 1.2. Comparison 1 Non-tailored self-help vs no self-help, pooled by amount of contact, Outcome 2 Neither group had face-to-face contact (Becona studies only).

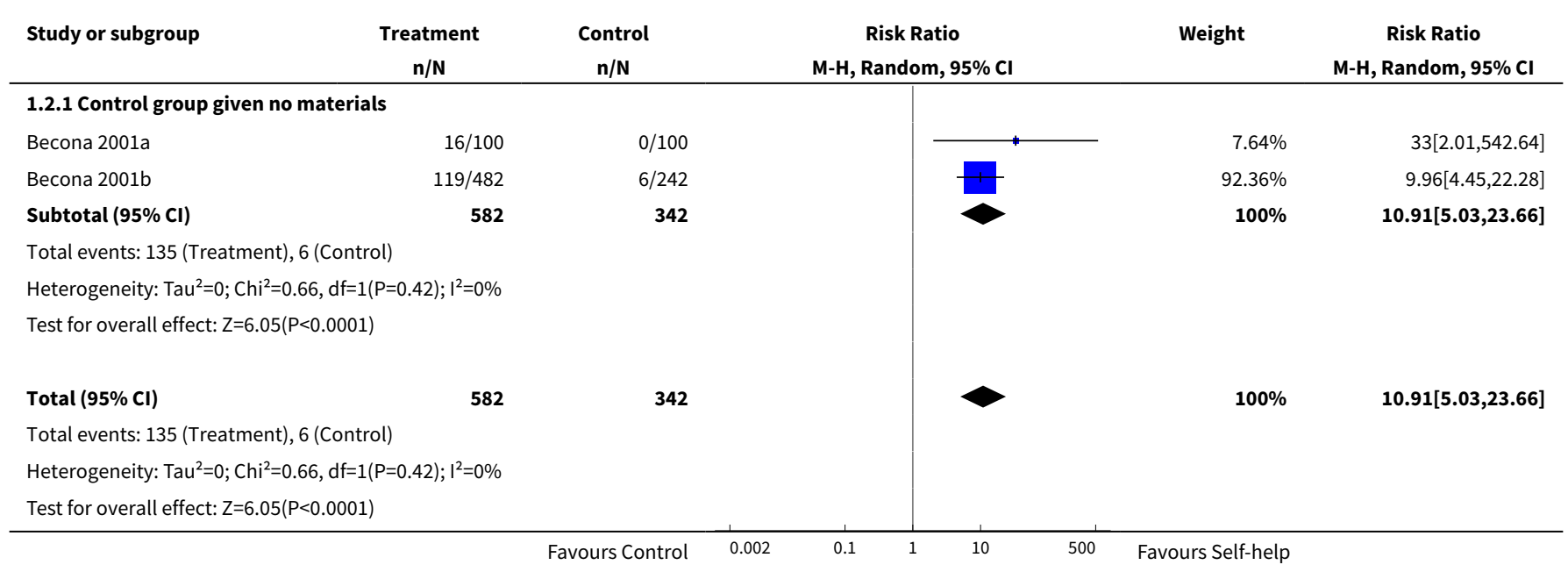


Analysis 1.3. Comparison 1 Non-tailored self-help vs no self-help, pooled by amount of contact, Outcome 3 Both groups had face-to-face contact (long-term abstinence).

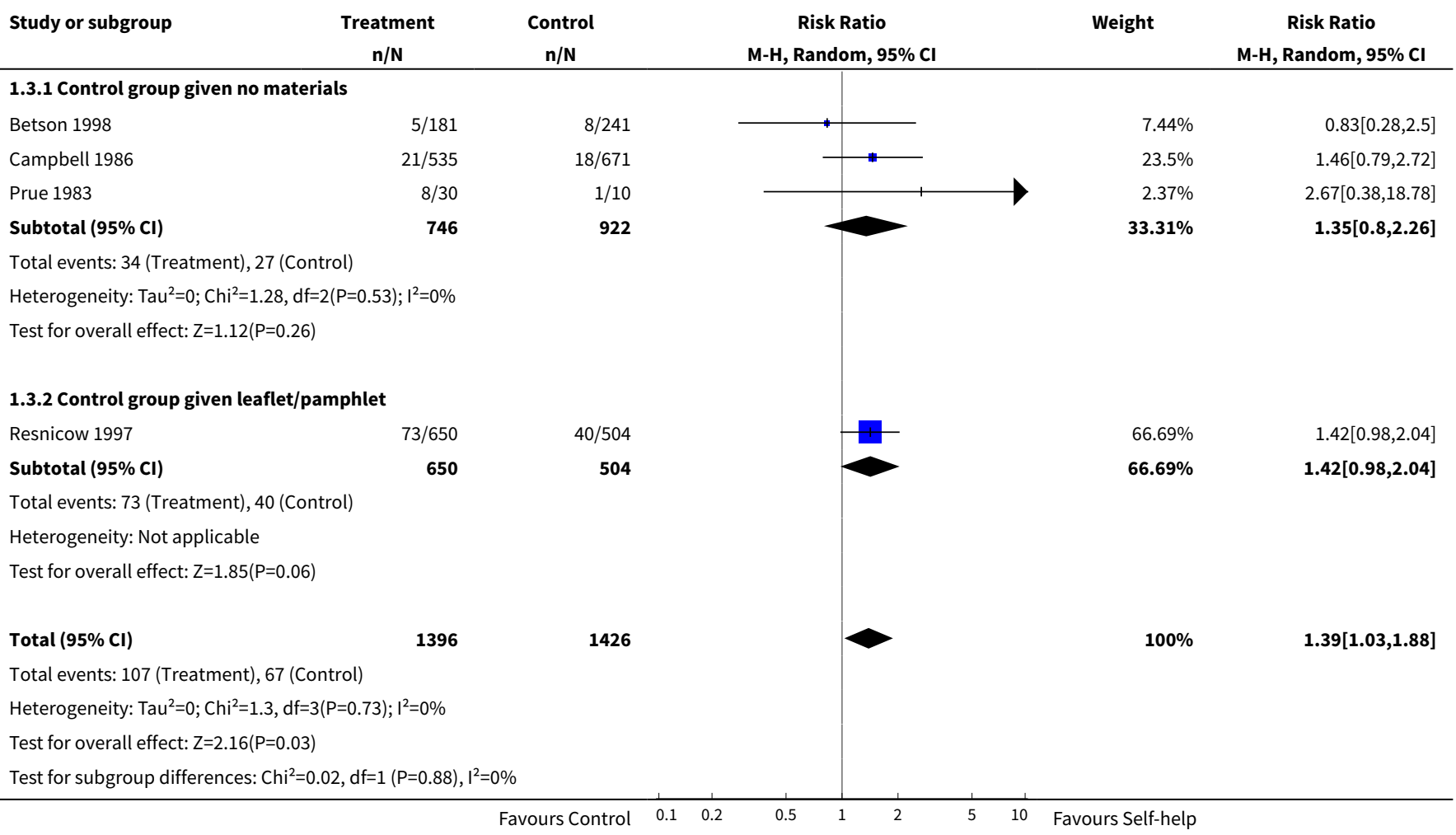

Analysis 1.4. Comparison 1 Non-tailored self-help vs no self-help, pooled by amount of contact, Outcome 4 Both groups had face-to-face contact with advice (long-term abstinence).

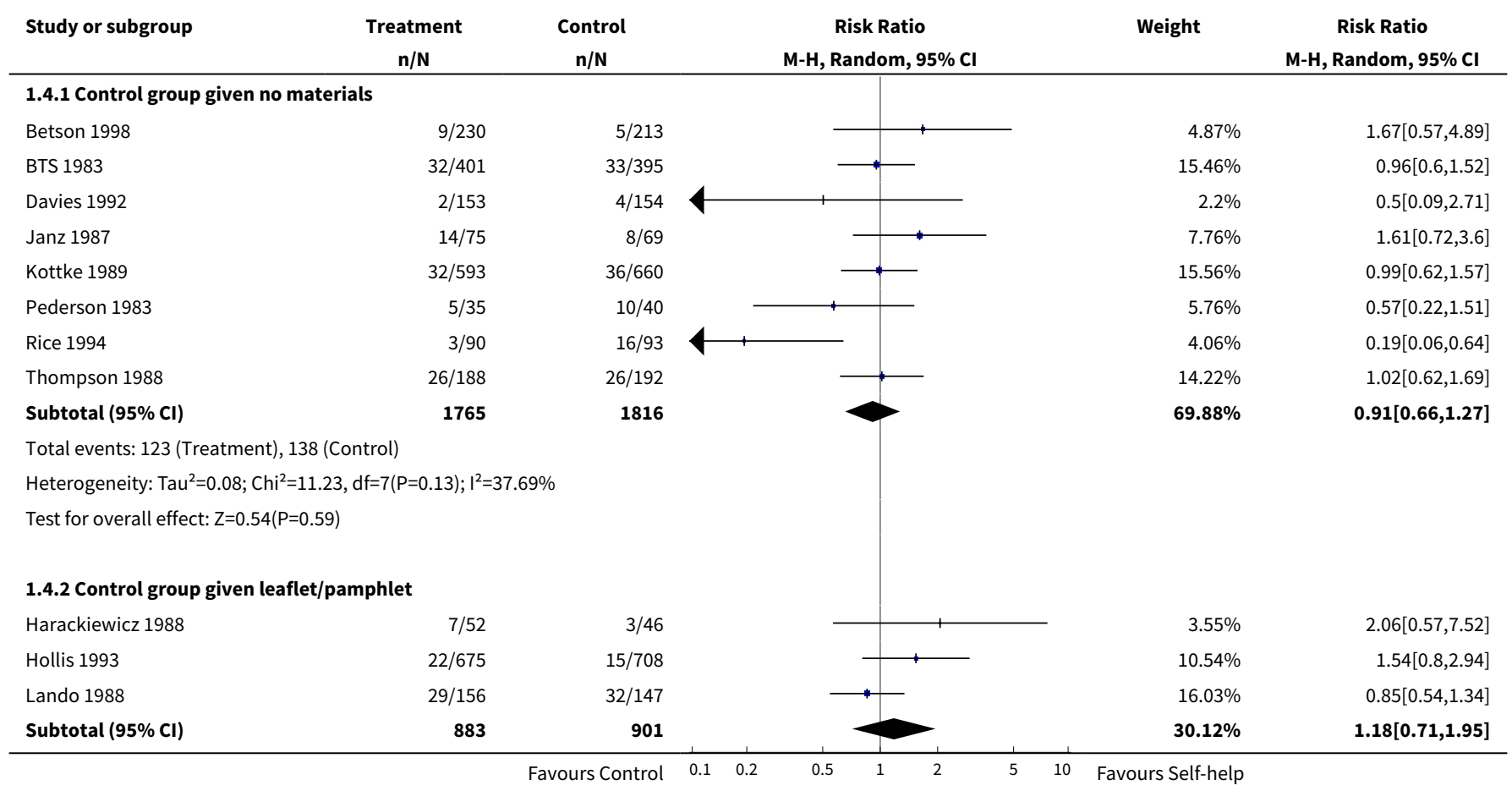




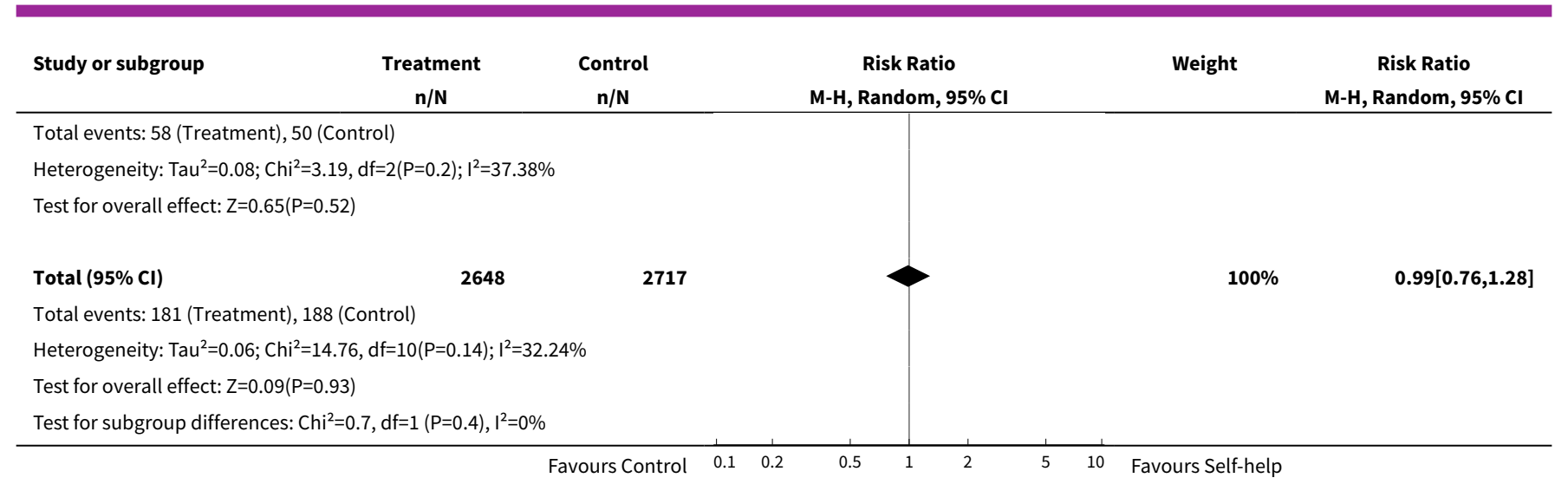

\section{Comparison 2. Non-tailored self-help vs no self-help, pooling all studies}

\begin{tabular}{|c|c|c|c|c|}
\hline Outcome or subgroup title & No. of studies & $\begin{array}{l}\text { No. of partici- } \\
\text { pants }\end{array}$ & Statistical method & Effect size \\
\hline 1 Long-term abstinence & 31 & 28451 & $\begin{array}{l}\text { Risk Ratio (M-H, Random, 95\% } \\
\mathrm{Cl} \text { ) }\end{array}$ & $1.06[0.95,1.19]$ \\
\hline $\begin{array}{l}1.1 \text { No contact/No materials for con- } \\
\text { trol }\end{array}$ & 11 & 13241 & $\begin{array}{l}\text { Risk Ratio (M-H, Random, 95\% } \\
\mathrm{Cl} \text { ) }\end{array}$ & $1.19[1.03,1.37]$ \\
\hline 1.2 No contact/Leaflet for control & 6 & 7023 & $\begin{array}{l}\text { Risk Ratio (M-H, Random, 95\% } \\
\text { Cl) }\end{array}$ & $0.87[0.71,1.07]$ \\
\hline $\begin{array}{l}\text { 1.3 Face-to-face contact/No materi- } \\
\text { als for control }\end{array}$ & 3 & 1668 & $\begin{array}{l}\text { Risk Ratio (M-H, Random, 95\% } \\
\text { Cl) }\end{array}$ & $1.35[0.80,2.26]$ \\
\hline $\begin{array}{l}\text { 1.4 Face-to-face contact/Leaflet for } \\
\text { control }\end{array}$ & 1 & 1154 & $\begin{array}{l}\text { Risk Ratio (M-H, Random, 95\% } \\
\text { Cl) }\end{array}$ & $1.42[0.98,2.04]$ \\
\hline 1.5 Advice/No materials for control & 8 & 3581 & $\begin{array}{l}\text { Risk Ratio (M-H, Random, 95\% } \\
\text { Cl) }\end{array}$ & $0.91[0.66,1.27]$ \\
\hline 1.6 Advice/Leaflet for control & 3 & 1784 & $\begin{array}{l}\text { Risk Ratio (M-H, Random, 95\% } \\
\mathrm{Cl} \text { ) }\end{array}$ & $1.18[0.71,1.95]$ \\
\hline
\end{tabular}

Analysis 2.1. Comparison 2 Non-tailored self-help vs no selfhelp, pooling all studies, Outcome 1 Long-term abstinence.

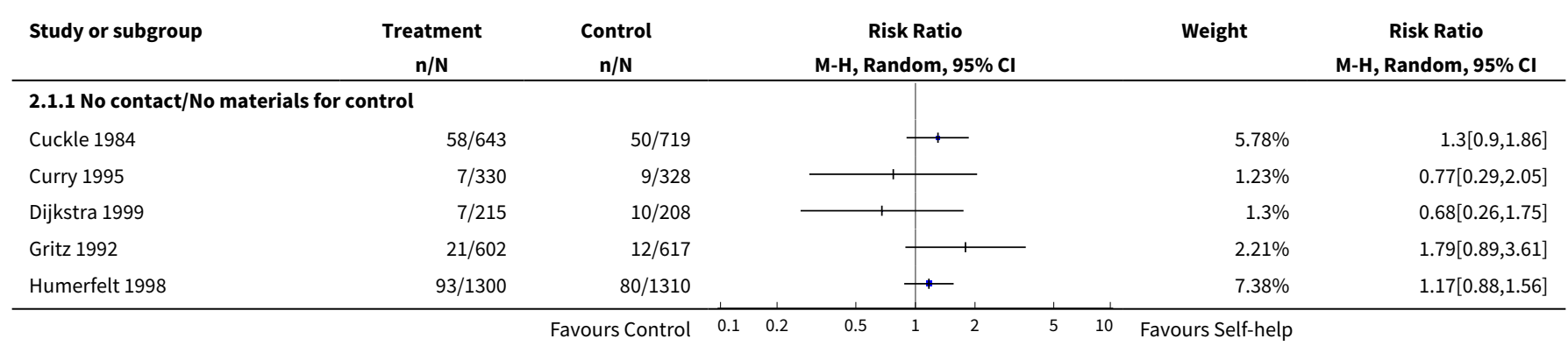




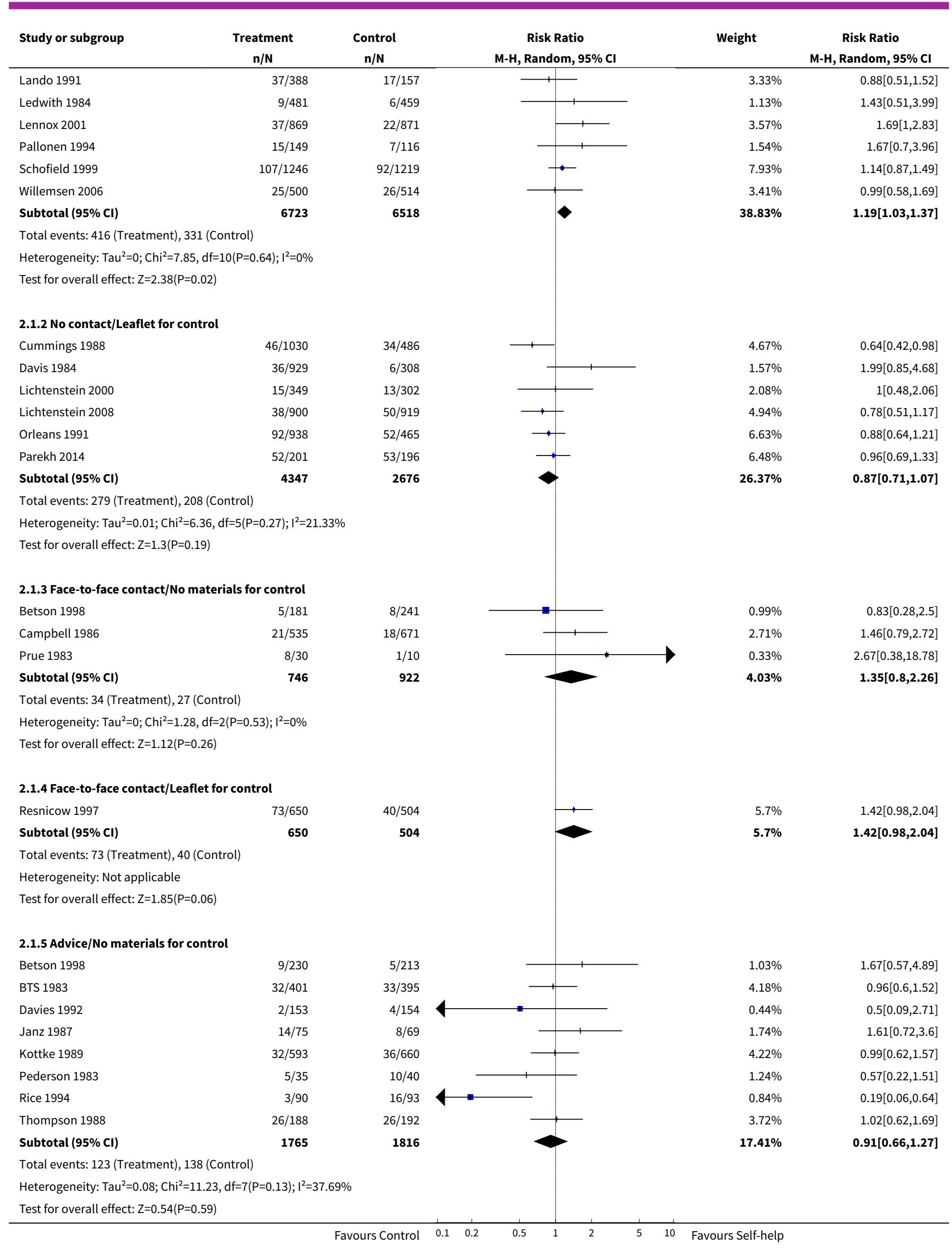

Print-based self-help interventions for smoking cessation (Review) 


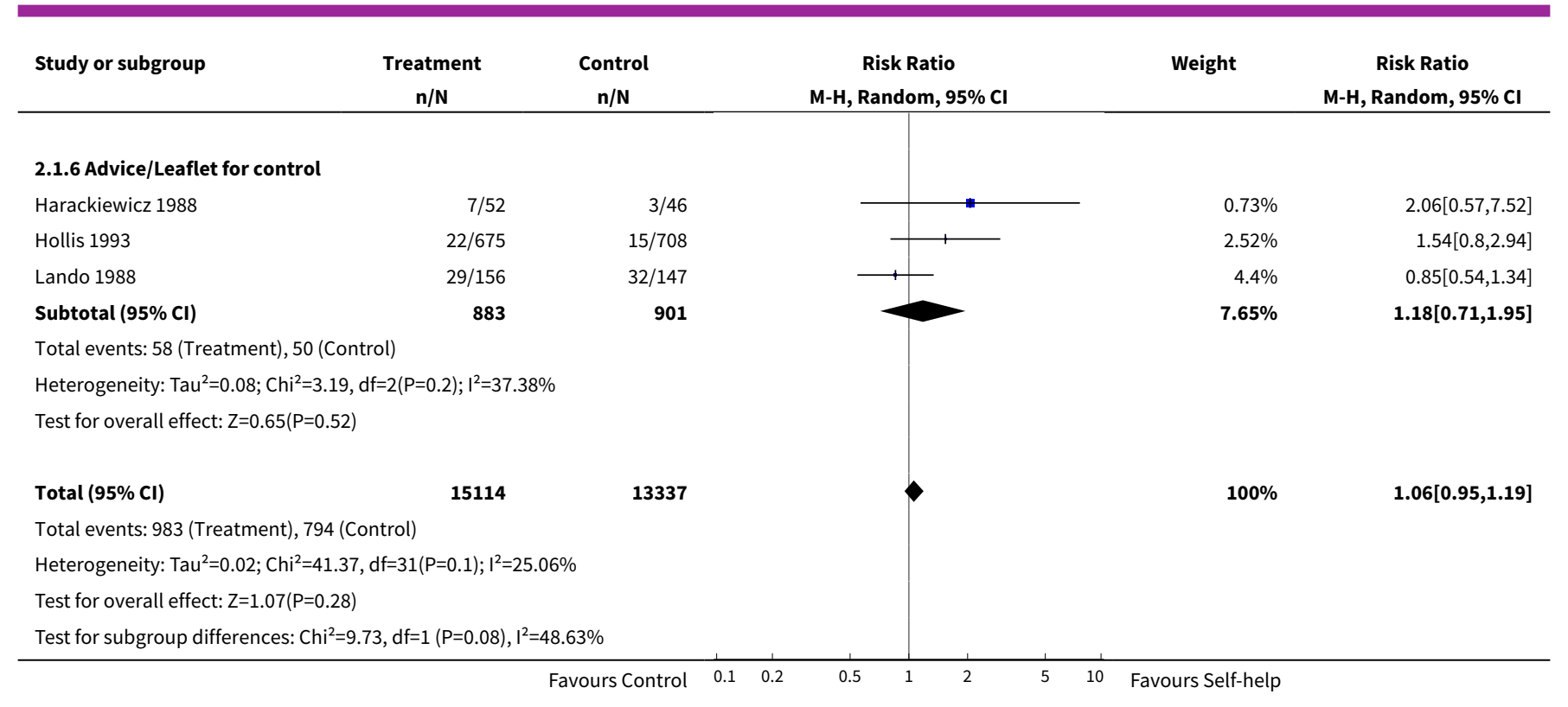

\section{Comparison 3. Tailored self-help vs no self-help}

\begin{tabular}{lllll}
\hline Outcome or subgroup title & No. of studies & $\begin{array}{l}\text { No. of partici- } \\
\text { pants }\end{array}$ & Statistical method & Effect size \\
\hline 1 Long-term abstinence & 12 & 19190 & $\begin{array}{l}\text { Risk Ratio (M-H, Random, } \\
95 \% \text { Cl) }\end{array}$ & 1.34 [1.20, 1.49] \\
\hline 1.1 Tailored materials vs no materials & 10 & 14359 & $\begin{array}{l}\text { Risk Ratio (M-H, Random, } \\
95 \% \text { Cl) }\end{array}$ & 1.34 [1.19, 1.51] \\
\hline 1.2 Tailored materials vs brief advice & 2 & 2992 & $\begin{array}{l}\text { Risk Ratio (M-H, Random, } \\
95 \% \text { Cl) }\end{array}$ & 1.13 [0.86, 1.49] \\
\hline $\begin{array}{l}1.3 \text { Tailored materials as an adjunct } \\
\text { to advice }\end{array}$ & 2 & 1839 & $\begin{array}{l}\text { Risk Ratio (M-H, Random, } \\
95 \% \text { Cl) }\end{array}$ & 1.72 [1.17, 2.53] \\
\hline
\end{tabular}

Analysis 3.1. Comparison 3 Tailored self-help vs no self-help, Outcome 1 Long-term abstinence.

\begin{tabular}{|c|c|c|c|c|c|}
\hline Study or subgroup & $\begin{array}{c}\text { Treatment } \\
\mathrm{n} / \mathrm{N} \\
\end{array}$ & $\begin{array}{c}\text { Control } \\
\mathrm{n} / \mathrm{N}\end{array}$ & $\begin{array}{c}\text { Risk Ratio } \\
\text { M-H, Random, } 95 \% \mathrm{CI}\end{array}$ & Weight & $\begin{array}{c}\text { Risk Ratio } \\
\text { M-H, Random, } 95 \% \mathrm{CI}\end{array}$ \\
\hline \multicolumn{6}{|c|}{ 3.1.1 Tailored materials vs no materials } \\
\hline Dijkstra 1998a & $26 / 1160$ & $4 / 386$ & & $1.04 \%$ & $2.16[0.76,6.16]$ \\
\hline Etter 2004 & $121 / 1467$ & $98 / 1467$ & *- & $17.3 \%$ & $1.23[0.96,1.6]$ \\
\hline Hoving 2010 & $6 / 256$ & $6 / 289$ & - & $0.91 \%$ & $1.13[0.37,3.46]$ \\
\hline Hoving 2010 & $22 / 220$ & $23 / 254$ & $\longrightarrow$ & $3.68 \%$ & $1.1[0.63,1.93]$ \\
\hline Meyer 2016 & $26 / 534$ & $16 / 388$ & + & $3.07 \%$ & $1.18[0.64,2.17]$ \\
\hline Prochaska 2001a & $25 / 362$ & $16 / 350$ & + & $3.06 \%$ & $1.51[0.82,2.78]$ \\
\hline Prochaska 2001b & $96 / 1358$ & $136 / 2786$ & - & $17.75 \%$ & $1.45[1.12,1.87]$ \\
\hline
\end{tabular}




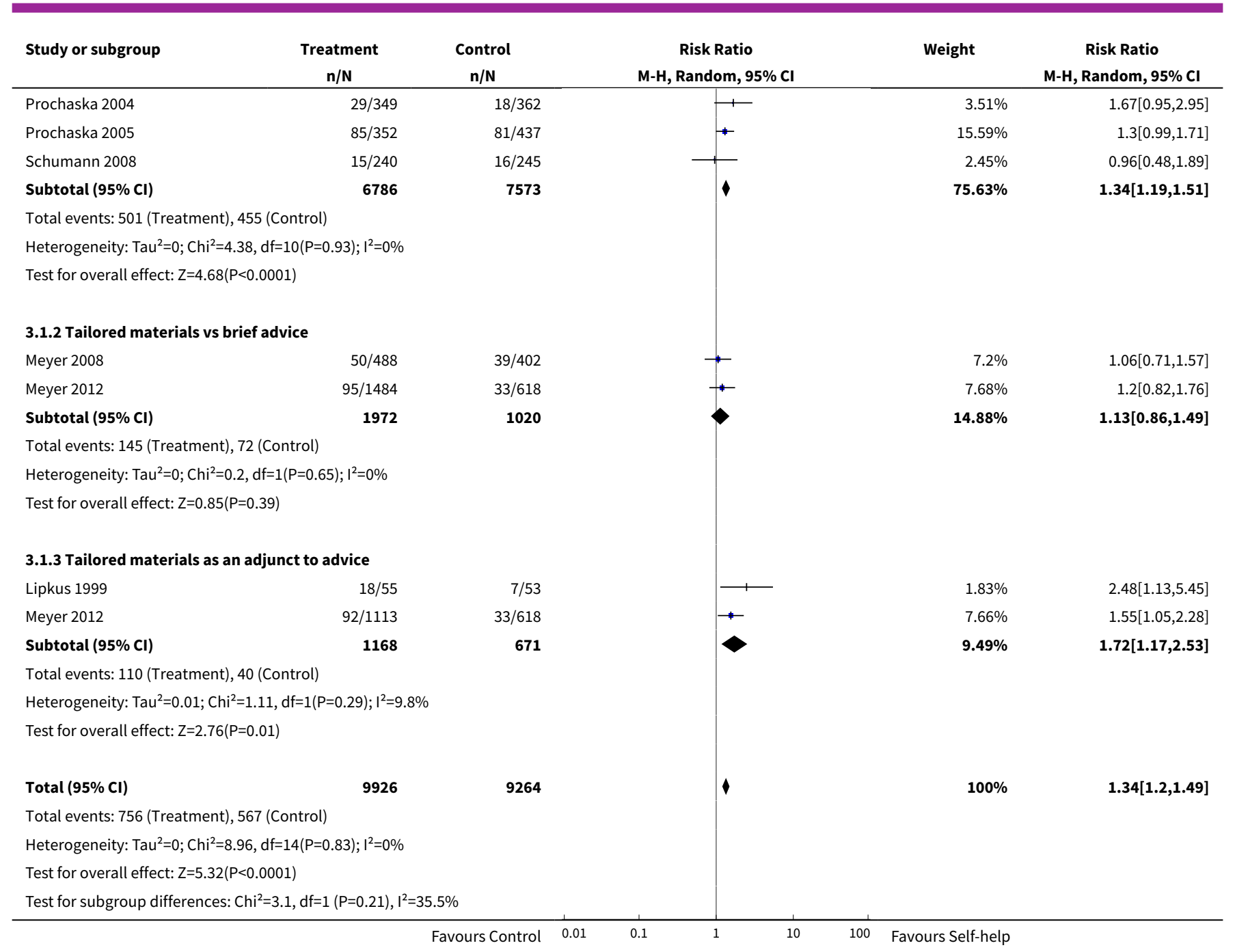

\section{Comparison 4. Tailored self-help vs non-tailored self-help}

\begin{tabular}{lllll}
\hline Outcome or subgroup title & No. of studies & $\begin{array}{l}\text { No. of partici- } \\
\text { pants }\end{array}$ & Statistical method & Effect size \\
\hline 1 Long-term abstinence & 19 & & $\begin{array}{l}\text { Risk Ratio (M-H, Random, } \\
95 \% \mathrm{Cl})\end{array}$ & Subtotals only \\
\hline $\begin{array}{l}1.1 \text { Tailored vs standard or stage- } \\
\text { matched materials (contact matched) }\end{array}$ & 10 & 11024 & $\begin{array}{l}\text { Risk Ratio (M-H, Random, } \\
95 \% \mathrm{Cl})\end{array}$ & $1.07[0.89,1.30]$ \\
\hline $\begin{array}{l}1.2 \text { Tailored multiple mailings vs standard } \\
\text { or stage-matched single mailing }\end{array}$ & 9 & 14166 & $\begin{array}{l}\text { Risk Ratio (M-H, Random, } \\
95 \% \mathrm{Cl})\end{array}$ & 1.42 [1.20, 1.68] \\
\hline
\end{tabular}


Analysis 4.1. Comparison 4 Tailored self-help vs non-tailored self-help, Outcome 1 Long-term abstinence.

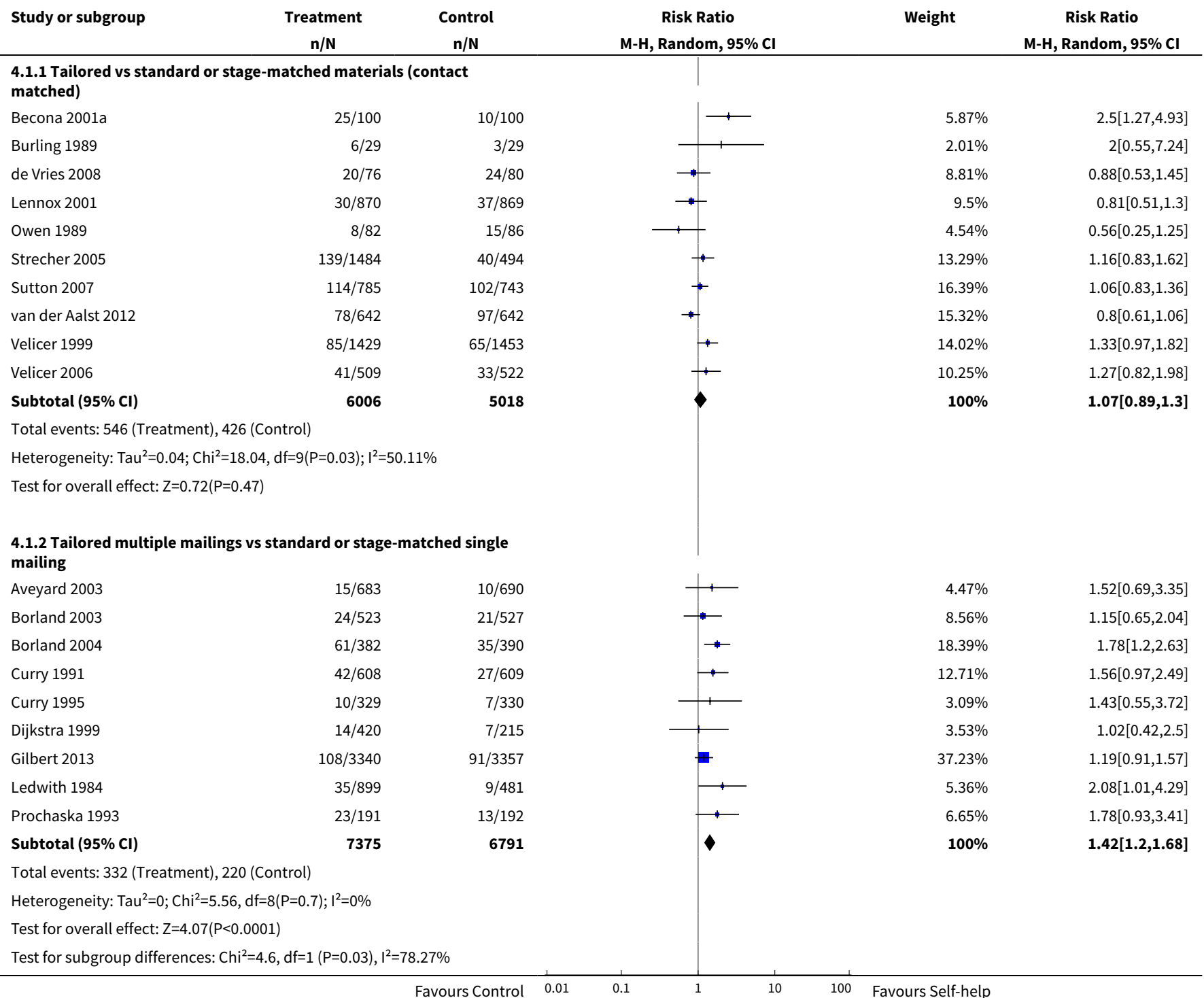

\section{Comparison 5. Self-help plus NRT vs NRT alone}

\begin{tabular}{llllll}
\hline Outcome or subgroup title & No. of studies & $\begin{array}{l}\text { No. of partici- } \\
\text { pants }\end{array}$ & Statistical method & Effect size \\
\hline 1 Long-term abstinence & 3 & 1769 & Risk Ratio (M-H, Random, 95\% Cl) & $1.05[0.86,1.30]$ \\
\hline 1.1 Non-tailored materials & 1 & 303 & Risk Ratio (M-H, Random, 95\% Cl) & $0.85[0.54,1.34]$ \\
\hline 1.2 Tailored materials & 2 & 1466 & Risk Ratio (M-H, Random, 95\% Cl) & $1.11[0.88,1.41]$ \\
\hline
\end{tabular}


Analysis 5.1. Comparison 5 Self-help plus NRT vs NRT alone, Outcome 1 Long-term abstinence.

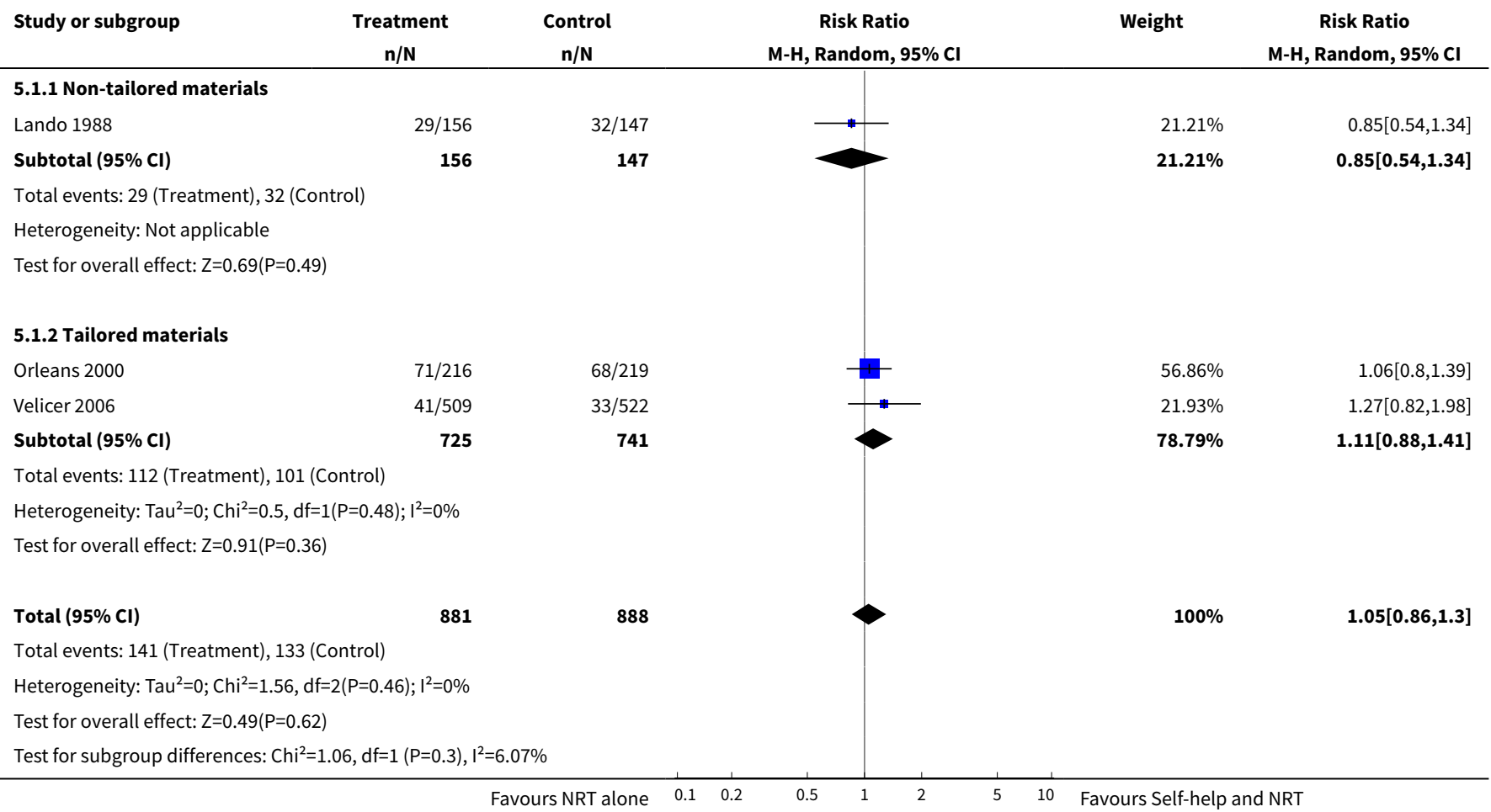

\section{Comparison 6. Other enhancements/adjuncts to self-help materials}

\begin{tabular}{|c|c|c|c|c|}
\hline Outcome or subgroup title & No. of studies & $\begin{array}{l}\text { No. of partici- } \\
\text { pants }\end{array}$ & Statistical method & Effect size \\
\hline 1 Long-term abstinence & 11 & & Risk Ratio (M-H, Random, 95\% Cl) & Subtotals only \\
\hline 1.1 Additional written materials & 4 & 4741 & Risk Ratio (M-H, Random, 95\% Cl) & $1.20[0.91,1.58]$ \\
\hline 1.2 Additional video & 2 & 424 & Risk Ratio (M-H, Random, 95\% Cl) & $0.73[0.35,1.51]$ \\
\hline $\begin{array}{l}\text { 1.3 Targeted materials vs stan- } \\
\text { dard materials }\end{array}$ & 5 & 3101 & Risk Ratio (M-H, Random, 95\% Cl) & $1.12[0.90,1.38]$ \\
\hline
\end{tabular}

Analysis 6.1. Comparison 6 Other enhancements/adjuncts to self-help materials, Outcome 1 Long-term abstinence.

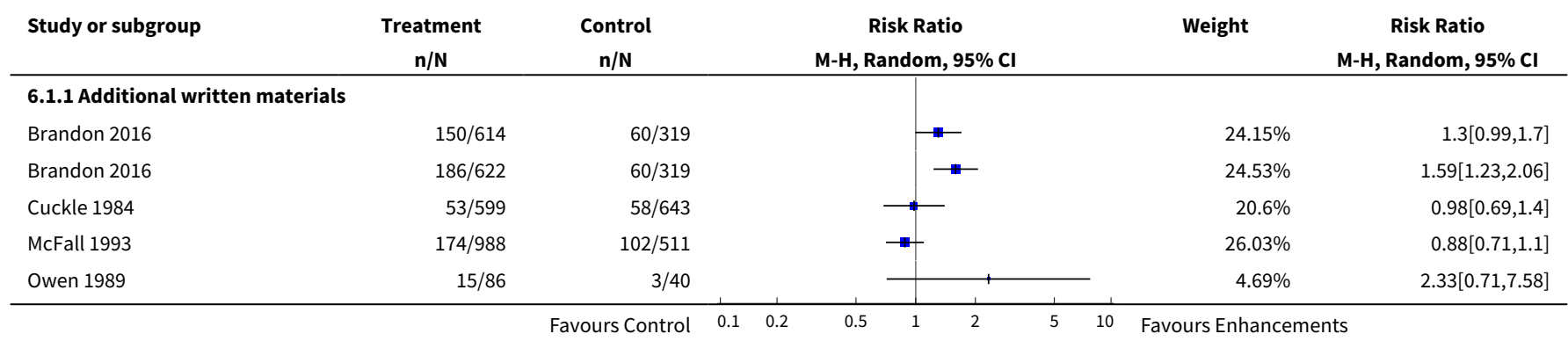




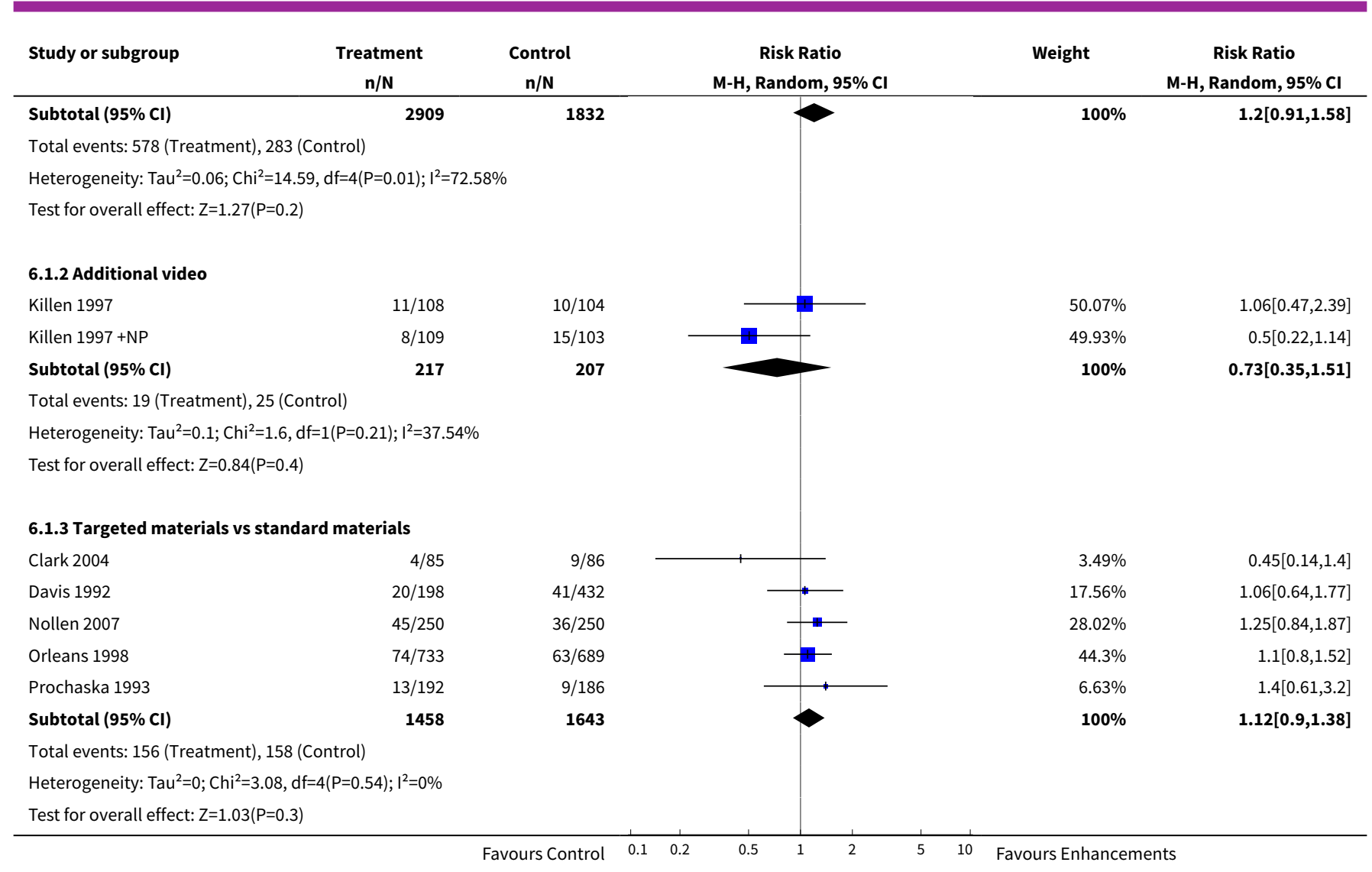

\section{APPENDICES}

\section{Appendix 1. CRS search strategy}

\#1 (self-help OR selfhelp OR manual ${ }^{\star}$ OR booklet* OR pamphlet $\left.{ }^{\star}\right): T I, A B, M H, E M T, K W, K Y, X K Y$

\#2 (leaflet* or letter $^{\star}$ or video*):TI,AB,MH,EMT,KW,KY,XKY

\#3 \#1 OR \#2

\section{WHAT'S NEW}

\begin{tabular}{lll}
\hline Date & Event & Description \\
\hline 9 January 2019 & Amended & Minor change to phrasing of abstract \\
\hline
\end{tabular}

\section{H ISTORY}

Protocol first published: Issue 2, 1998

Review first published: Issue 4, 1998

\begin{tabular}{lll}
\hline Date & Event & Description \\
\hline 5 September 2018 & $\begin{array}{l}\text { New citation required but conclusions } \\
\text { have not changed }\end{array}$ & Conclusions unchanged \\
\hline \hline
\end{tabular}

Print-based self-help interventions for smoking cessation (Review) 


\begin{tabular}{|c|c|c|}
\hline Date & Event & Description \\
\hline 5 September 2018 & New search has been performed & Search updated to March 2018. Three new studies included \\
\hline 7 May 2014 & $\begin{array}{l}\text { New citation required but conclusions } \\
\text { have not changed }\end{array}$ & $\begin{array}{l}\text { JH-B added as author. Review title changed from "Self-help in- } \\
\text { terventions for smoking cessation" }\end{array}$ \\
\hline 7 May 2014 & New search has been performed & $\begin{array}{l}\text { Updated with } 6 \text { new studies. 'Summary of findings' table added. } \\
\text { Risk of bias domains added }\end{array}$ \\
\hline 28 January 2009 & New search has been performed & $\begin{array}{l}\text { Updated with } 10 \text { new studies for Issue 2, 2009. No major changes } \\
\text { to results }\end{array}$ \\
\hline 29 October 2008 & Amended & Converted to new review format \\
\hline 28 April 2005 & $\begin{array}{l}\text { New citation required and minor } \\
\text { changes }\end{array}$ & $\begin{array}{l}\text { Updated for Issue 3, 2005, with } 9 \text { new studies. Most studies used } \\
\text { tailored interventions and strengthened the evidence that tai- } \\
\text { lored materials are more useful than standard ones }\end{array}$ \\
\hline 10 April 2002 & $\begin{array}{l}\text { New citation required and minor } \\
\text { changes }\end{array}$ & $\begin{array}{l}\text { Updated for Issue 3, 2002, with } 10 \text { new studies. Most studies used } \\
\text { tailored interventions and strengthened the evidence that tai- } \\
\text { lored materials are more useful than standard ones }\end{array}$ \\
\hline 13 October 1999 & New search has been performed & Updated for Issue 1, 2000, with 4 new trials \\
\hline
\end{tabular}

\section{CONTRIBUTIONS OFAUTHORS}

In the most recent update, JLB conducted searches for studies, and JLB and JMOM performed study screening and data extraction. JLB updated the text and meta-analyses with oversight from JHB. All review authors reviewed, commented on, and approved the final manuscript.

\section{DECLARATIONS OF INTEREST}

JLB: none known.

JMOM: none known.

JHB: none known.

\section{SOURCES OF SUPPORT}

\section{Internal sources}

- Nuffield Department of Primary Care Health Sciences, University of Oxford, UK.

- National Institute for Health Research (NIHR) School for Primary Care Research, UK.

\section{External sources}

- National Institute for Health Research (NIHR) Cochrane Programme Grant, UK.

- National Institute for Health Research (NIHR) Community Healthcare Medtech and In Vitro Diagnostics Cooperative (MIC), UK.

- NIHR Biomedical Research Centre, Oxford, UK.

\section{DIFFERENCES BETWEEN PROTOCOL AND REVIEW}

Studies testing telephone counselling as an adjunct to print-based self-help or interventions for preventing smoking relapse are no longer included in this review as they are included in other Cochrane Reviews.

As of the 2018 update of this review, we conducted meta-analyses using a random-effects model in accordance with new guidance from the Cochrane Tobacco Addiction Group. 


\section{N D EX TERMS}

\section{Medical Subject Headings (MeSH)}

*Smoking Prevention; Behavior Therapy; Chewing Gum; Nicotine [analogs \& derivatives] [therapeutic use]; Pamphlets; Patient Education as Topic; Polymethacrylic Acids [therapeutic use]; Polyvinyls [therapeutic use]; Randomized Controlled Trials as Topic; Self Care [ ${ }^{*}$ methods]; Smoking Cessation [ ${ }^{*}$ methods]; Temperance [statistics \& numerical data]; Tobacco Use Cessation Devices

\section{MeSH check words}

Humans 